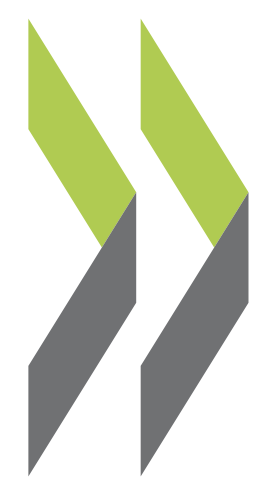

SIGMA Papers No. 54

\title{
Developing Effective Working Relationships Between Supreme Audit Institutions and Parliaments
} Bianca Brétéché, Alastair Swarbrick 


\section{Developing effective working relationships between supreme audit institutions and parliaments}

SIGMA PAPER No. 54

Authorised for publication by Karen Hill, Head of the SIGMA Programme 


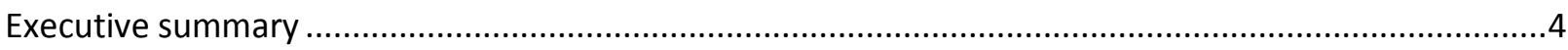

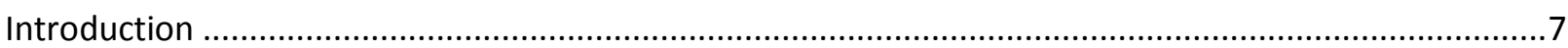

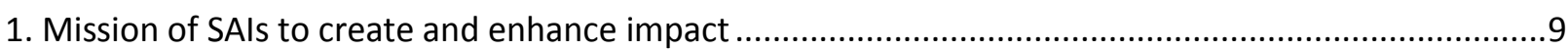

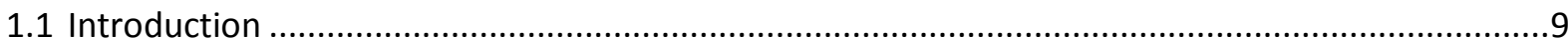

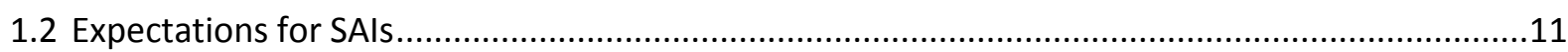

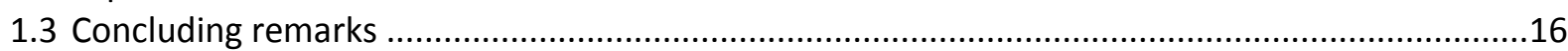

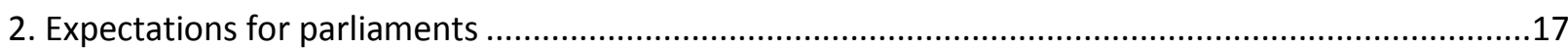

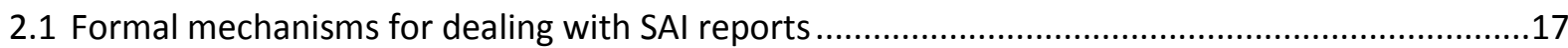

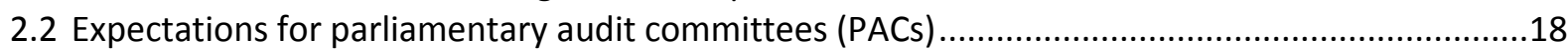

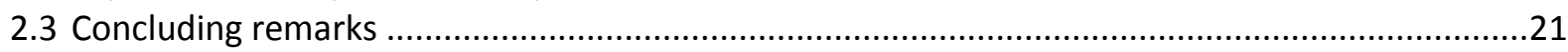

3. Relations between SAls and parliaments: some contextual factors..................................................22

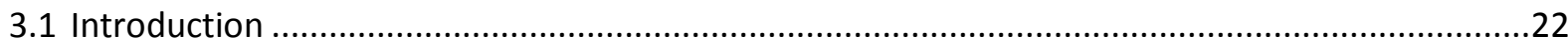

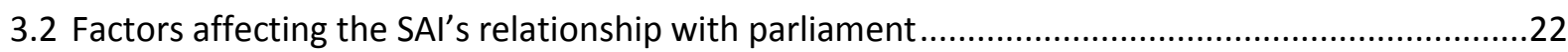

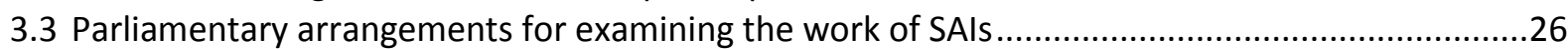

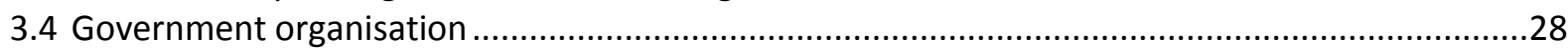

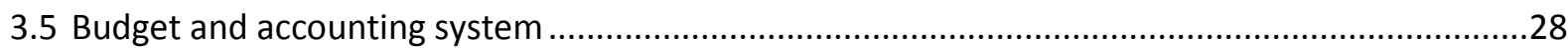

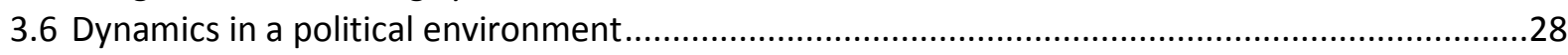

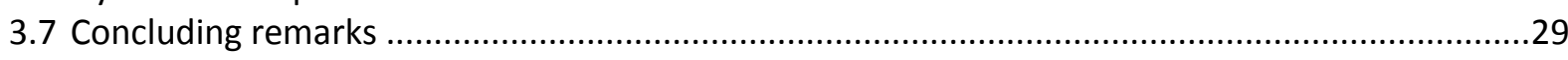

4. Analysis of working relationships between SAls and parliaments: Good practices in Europe and key

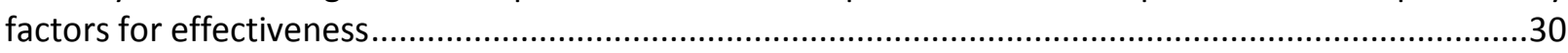

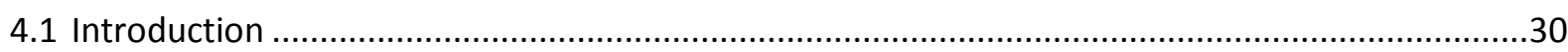

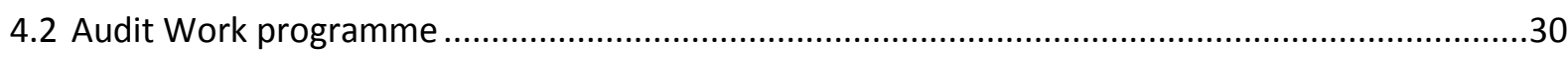

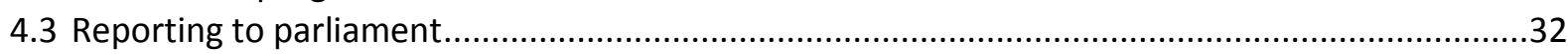

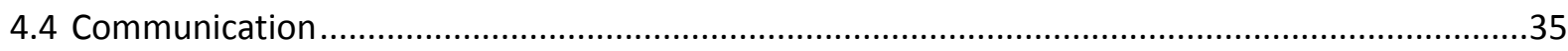

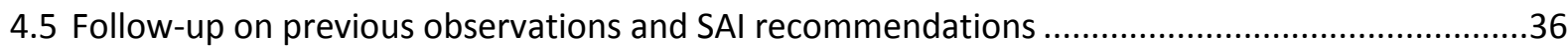

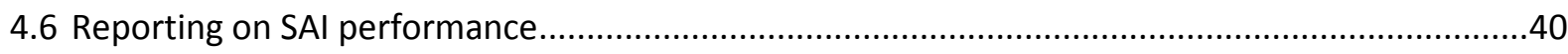

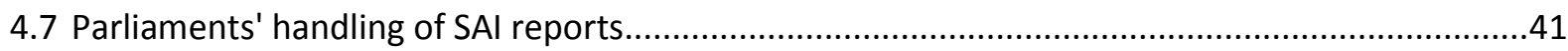

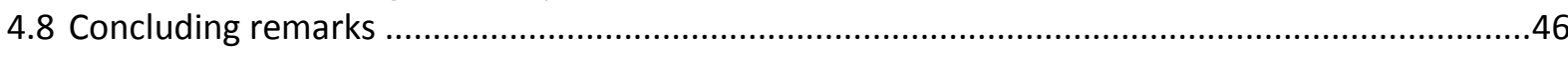

Annex 1. International Standards and acknowledged Principles for relations between parliaments and

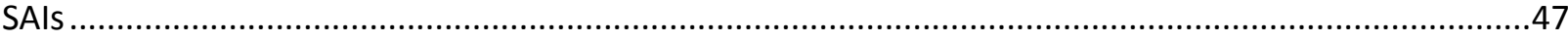

Annex 2. Toolkit for strengthening working relationships between SAls and parliaments.....................53

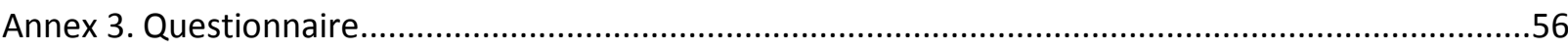

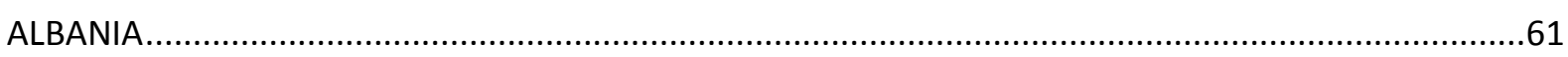

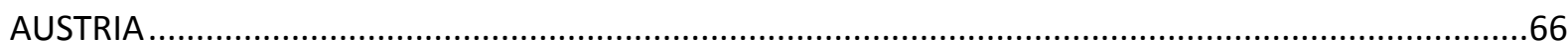

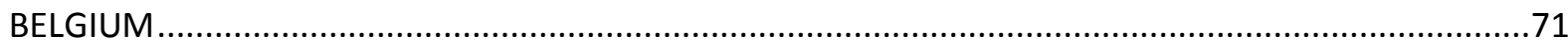

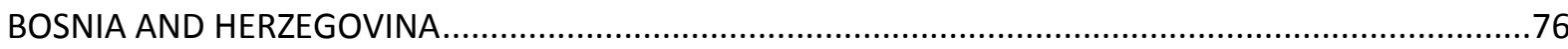

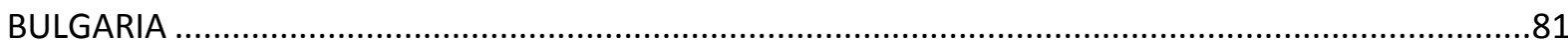




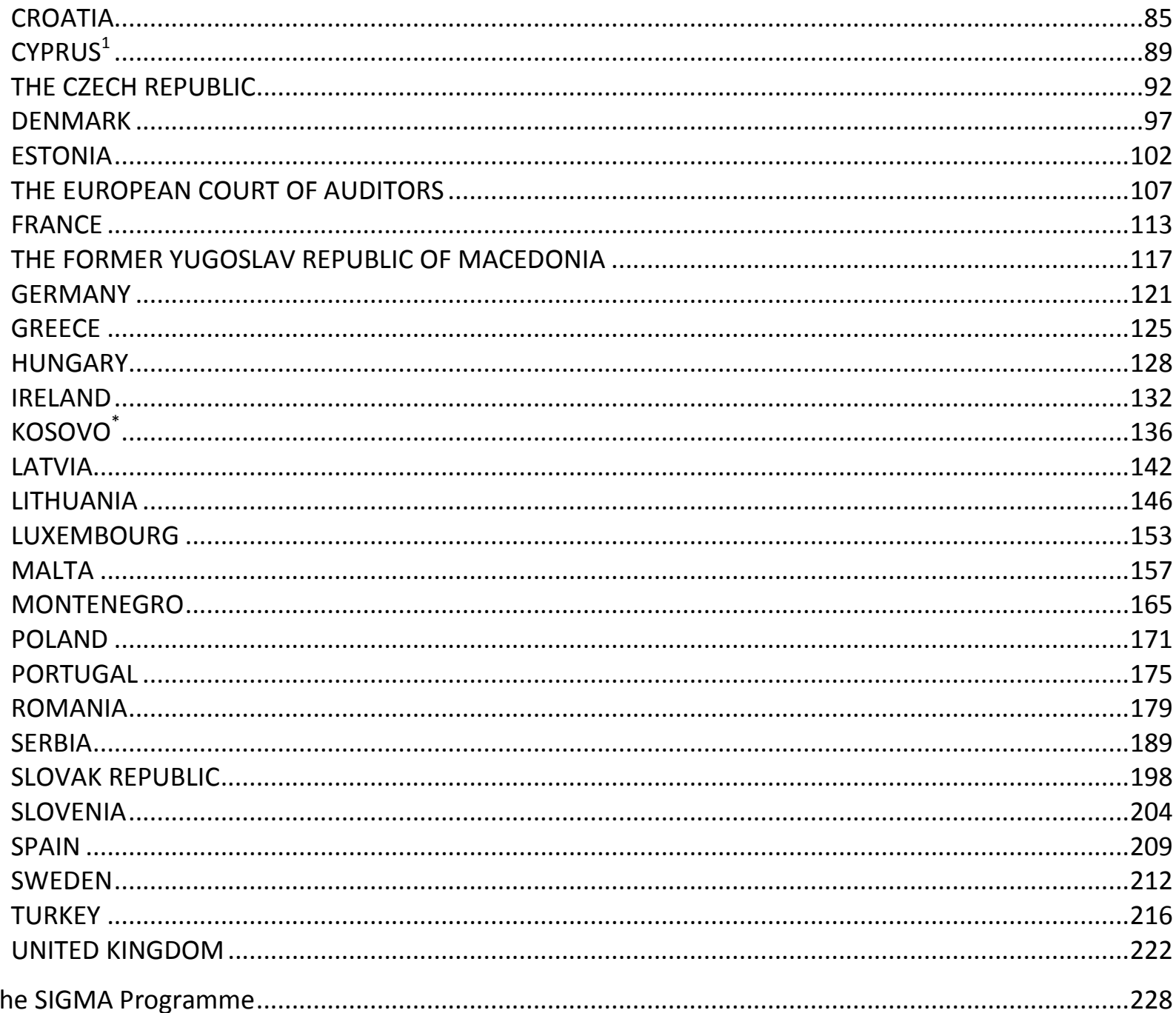

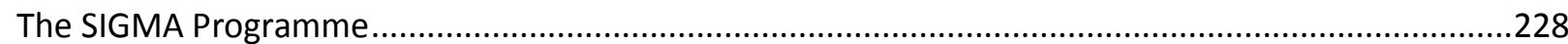

1. Note by Turkey

The information in this document with reference to "Cyprus" relates to the southern part of the Island. There is no single authority representing both Turkish and Greek Cypriot people on the Island. Turkey recognises the Turkish Republic of Northern Cyprus (TRNC). Until a lasting and equitable solution is found within the context of the United Nations, Turkey shall preserve its position concerning the "Cyprus issue".

Note by all the European Union Member States of the OECD and the European Union

The Republic of Cyprus is recognised by all members of the United Nations with the exception of Turkey. The information in this document relates to the area under the effective control of the Government of the Republic of Cyprus.

This designation is without prejudice to positions on status, and is in line with United Nations Security Council Resolution $1244 / 99$ and the Advisory Opinion of the International Court of Justice on Kosovo's declaration of independence. 


\section{EXECUTIVE SUMMARY}

Supreme audit institutions (SAIs) and parliaments are the two most important players for holding governments to account for the use of public funds. Parliaments do not usually have the capacity or expertise to scrutinise the use of public funds by the government themselves. They rely on the objective and professional view of the SAl to provide them with assurance and information about the reliability of financial reports and the use of public resources.

Parliaments, however, will only use the work of the SAls if it is interesting and understandable in a political context. In fulfilling their role within the accountability system it is therefore important for SAls to ensure that their work is relevant, adds value and has impact, not only by reviewing and reporting on what has happened, but also by looking forward, identifying where improvements can be made, and promoting Good practice. In this way, public sector audit contributes to improved standards of governance, better management and decision making, and more effective use of public money.

This paper offers guidance to SAls and parliaments for establishing effective working relationships. It describes and analyses international standards and contextual factors, as well as features and practices across Europe, and highlights key issues for effective relations and areas of Good practice. It also offers a toolkit for strengthening working relations between SAls and parliaments. The report is based on the contributions of 33 SAls from European Union (EU) member countries and EU candidate countries and potential candidates.

The paper describes the current international standards, which set high expectations on SAls concerning the way they report to parliaments about their audit work and the efforts they need to undertake to assist members of parliament to understand and use audit reports. SAls are also required to engage with their parliament regularly in order to be aware of its expectations and to make sure parliamentarians understand the role of the SAI and how they can benefit from its work.

The paper further identifies a number of factors that influence these relationships, which have to be taken into account when looking to develop practical arrangements between the SAI and the parliament. The constitutional and historical background of the SAI, the parliamentary system, the governmental organisation, and the budget and accounting system all shape the relationships between the SAI and the parliament.

In response to a survey conducted by SIGMA in early 2016, 33 SAls replied describing how they meet these expectations. They also provided information about the way their respective parliaments use their work. The survey results confirm that all SAls continuously review how they can increase their impact by developing new procedures, targeting communication, increasing transparency, and being pro-active. The diversity and variety of the reported practices is a source of inspiration for any SAI looking to enhance the impact of its working relationship with parliament. To some extent this holds true as well for parliaments that want to take their duty to use SAI reports for holding government to account seriously.

Effective working relations begin with different means of co-operation in the planning phase of annual and multi-annual Work programmes of SAls. Most SAls pay attention to specific suggestions for audits coming from their parliament, whether legal provisions exist for the parliament to request audits or not. Examples of Good practices identified to achieve this included agreeing with parliament the 
consultation procedure for audit requests and limiting the number of audits on request to be carried out. They also included informing parliament about the SAI's Work programme and strategic audit plan, organising opportunities for parliament to regularly provide input, liaising with the dedicated committee and other relevant committees, and following relevant discussions in parliament for identification of potential audits.

The foundation of the relationship between SAls and parliaments are the audit reports that SAls send to the parliament. While all European SAls report to parliament there are significant differences between the countries as to when, how and how often they do it. Good practices adopted by SAls for reporting to parliament included:

- submitting reports to parliament and publishing them at the same time;

- making sure reports are distributed among all relevant members/committees;

- offering presentations and briefings on reports;

- using press releases to highlight important issues included in reports;

- being selective in the reports submitted to parliament or giving advice on which reports to select for examination;

- considering thematic reports assembling results from previous audits.

Many SAls go beyond just providing parliaments with audit reports and take initiatives to establish good working relationships with their parliaments, raise awareness about the role of SAls and assist in understanding audit reports. These communication activities also seek to increase the attention parliaments pay to SAl reports. Good practices identified for communicating with parliaments included: holding regular meetings, supplemented by informal contacts at working level and interviews; co-ordinating agendas and reporting timetables; organising conferences, roundtables, and workshops; agreeing memoranda of understanding on procedures for co-operation; establishing a communication policy; and improving understanding through the secondment of staff.

The most common parliamentary arrangement for co-operating with SAls and using their work to hold governments to account consists of designating this task to a parliamentary committee. Throughout European parliaments this task belongs to the budget committees or specific public audit committees, which can be standing committees or subcommittees. In a number of countries, sectoral committees are also playing a role in stimulating and using the audit work of SAls. The Good practices for parliamentary arrangements identified include:

- ensuring adequate organisation of committee responsibilities for SAI reports;

- setting up a specialised audit committee or audit subcommittee;

- ensuring availability of sufficient staff and analytical resources in parliament;

- involving sectoral committees especially in dealing with performance audit reports;

- using a formal discharge procedure as part of the budget cycle.

In order to ensure that their audit work achieves results and contributes to improved management of public funds, all European SAls monitor the follow-up of their observations and the implementation of recommendations made in their audit reports. Many SAls also maintain a database and some publish information about the way audited public institutions act upon audit findings. Other Good 
practices identified for follow-up procedures included reporting on implementation of recommendations at fixed intervals, integrating the monitoring system into the system for planning of review and follow-up audits, and paying specific attention to reporting on implementation of recommendations in performance audit reports.

The audit work of SAls gains greater impact if parliaments also follow-up on audit work in exercising their budgetary oversight over the government. Many parliaments in Europe have developed relevant procedures. Good practice examples involve:

- development of standard procedures and schedules for parliamentary discussion on SAI reports that makes timely conclusions possible;

- assigning a rapporteur for specific SAI reports;

- organisation of hearings with auditees;

- requiring action plans from government or auditee, and setting deadlines for measures to taken;

- considering sanctions in cases of serious non-compliance with recommendations from the SAI or parliament (political, financial and disciplinary);

- requiring reports from auditee or government on implementation of adequate measures.

Almost all SAls report to parliament on their own performance to provide accountability for their work. This is generally done through reporting on their activities and their use of resources in the previous year, either in a separate annual activity report or in a dedicated chapter of their annual report. Good practice in this regard involved providing parliament with an audited annual report on accounts and use of resources and an annual report on activities and implementation of the Work programme. Other examples included external peer reviews on a regular basis and estimations of savings made for the public sector.

These Good practices, linked to the relevant standards and principles, result in a "Toolkit for strengthening working relationships between SAls and parliaments" included in Annex 2. There is no "one size fits all" for effective relations between SAls and parliaments, and over time relations will need to be reshaped. But the toolkit can help in looking for new instruments or procedures to maintain and improve effective working relationships. 


\section{INTRODUCTION}

In recent years the SAI community has been examining how its work can have impact and contribute to making a difference to the lives of citizens. The endorsement of International Standard of Supreme Audit Institutions $^{1}$ (ISSAI) 12 The Value and Benefits of SAls ${ }^{2}$ by the International Organisation of Supreme Audit Institutions (INTOSAI) in 2013 clearly demonstrates the important role that SAls have in improving the use of public resources and encouraging more effective delivery of public services. A key component to support this ambition is the development of effective relationships between SAls and their respective parliaments.

The SAls of the network of EU candidate and potential candidate countries (the Network) identified "increasing the impact of SAIs" as a common priority during their meeting in Istanbul in 2011, particularly in co-operation with the national parliaments. In November 2013 the SAI of Montenegro hosted a Network conference on the relations between SAls and parliaments which resulted in a decision to develop this guidance paper. The aim is to provide examples of Good practice in developing and managing effective relationships with parliament, but also to help in identifying opportunities for strengthening the mutually beneficial working relationship with parliaments. SIGMA agreed to assist the Network in developing the guidance paper.

The main purpose of this guidance paper is to present an overview of practices employed within EU and Network countries for developing relationships between SAls and parliaments. It draws out the key factors that support effective relationships, and identifies Good practices that could be employed. The paper explores the expectations established in various standards, guidance and literature for these relationships, as well as the impact of the diverse political, constitutional, legal and administrative frameworks and traditions that influence institutional structures and accountability frameworks. The overall goal is to provide the Network with ideas and solutions to enhance their engagement with their respective parliaments as they continue to build their capacity to deliver audits with increasing impact.

The paper has been developed taking account of the requirements of the ISSAIs and other standards, publicly available literature and input from the SAls of EU member countries and the Network in the form of a survey. Survey responses were received from 33 of the 36 institutions that were invited and details of the survey can be found in Part 2 of the paper.

Chapter 1 sets out the theoretical background for accountability and explores the relevant standards and principles for SAls for effective working relationships with parliaments. Chapter 2 explores the expectations which exist for parliaments. Chapter 3 analyses the context behind the relations between SAls and parliaments. Chapter 4 analyses the current relationships to distil Good practices in line with the standards and principles identified in Chapters 1 and 2. This results in what could be called a toolkit of Good practices for SAls and parliaments to explore when they are looking for enhancing the effectiveness of their relationships.

The focus of this paper about SAI relationships with parliaments is on how an SAI can increase the impact of its work. Therefore the scope has been limited to examine those areas directly relevant to

International Standards of Supreme Audit Institutions (ISSAIs), http://www.issai.org/.

ISSAI 12, The Value and Benefits of SAls - Making a Difference to the Lives of Citizens (endorsed 2013), available at http://www.issai.org/en us/site-issai/issai-framework/2-prerequisites-for-the-functioning-of-sais.htm. 
the effective use and impact of audit reports and other products of an SAl such as opinions and advice. Other areas where the interests of the SAI and parliament intersect, for instance the parliamentary appointment procedure for an Auditor General or SAI President, or the adoption of the SAl's budget, have not been considered.

The contributions of the SAIs from across EU member countries and the Network, and in particular the support of the working group from the SAls of Turkey, Albania, Kosovo and Serbia to the development of this paper are gratefully acknowledged. The report has been drafted with expert contributions from Mr. Jan Pieter Lingen and Mr. Klaus Goetz, and reviewed by Mr. Alastair Swarbrick and Mrs. Bianca Brétéché. 


\title{
1. MISSION OF SAIS TO CREATE AND ENHANCE IMPACT
}

\subsection{Introduction}

\author{
According to the Lima Declaration (ISSAI 1, Section 1)
}

"The concept and establishment of audit is inherent in public financial administration as the management of public funds represents a trust. Audit is not an end in itself but an indispensable part of a regulatory system whose aim is to reveal deviations from accepted standards and violations of the principles of legality, efficiency effectiveness and economy of financial management early enough to make it possible to take corrective action in individual cases, to make those accountable accept responsibility, to obtain compensation, or to take steps to prevent - or at least render more difficult such breaches".

Within a robust system of public financial accountability, those responsible for conducting public business and using public resources will be held accountable to those who use and pay for the services provided, in accordance with the law and proper standards. Public resources should be safeguarded, properly accounted for, and used economically, efficiently and effectively.

A fundamental role of a parliament is to authorise the budget of the government and to hold it to account for the execution of the budget, ensuring on behalf of the citizens and users of public services that it uses resources legally and responsibly, for the purposes intended, and economically, efficiently and effectively. To do this effectively, members of parliament need objective and fact-based information about how well the government collects and spends public funds.

SAls play an important role in this system of accountability between the parliament and government (executive), and externally to citizens and users of public services. They provide independent and objective reports and information on: the reliability of a government's financial reports; its use of resources; the safeguarding of the assets and resources entrusted to it; and compliance with the laws, regulations and other relevant authorities which enable parliaments (and other stakeholders) to hold a government to account. The fundamental reason why SAls exist is to provide assurance and credible information to stakeholders in the interest of the public.

The relationship of SAls with their respective parliament and the government is effectively represented in the accountability triangle (see Figure 1). Within this framework, SAls need to reflect on how they can best fulfil their function in relation to the other actors in the system.

ISSAI 1, The Lima Declaration (endorsed 1977), available at http://www.issai.org/en us/site-issai/issai-framework. 


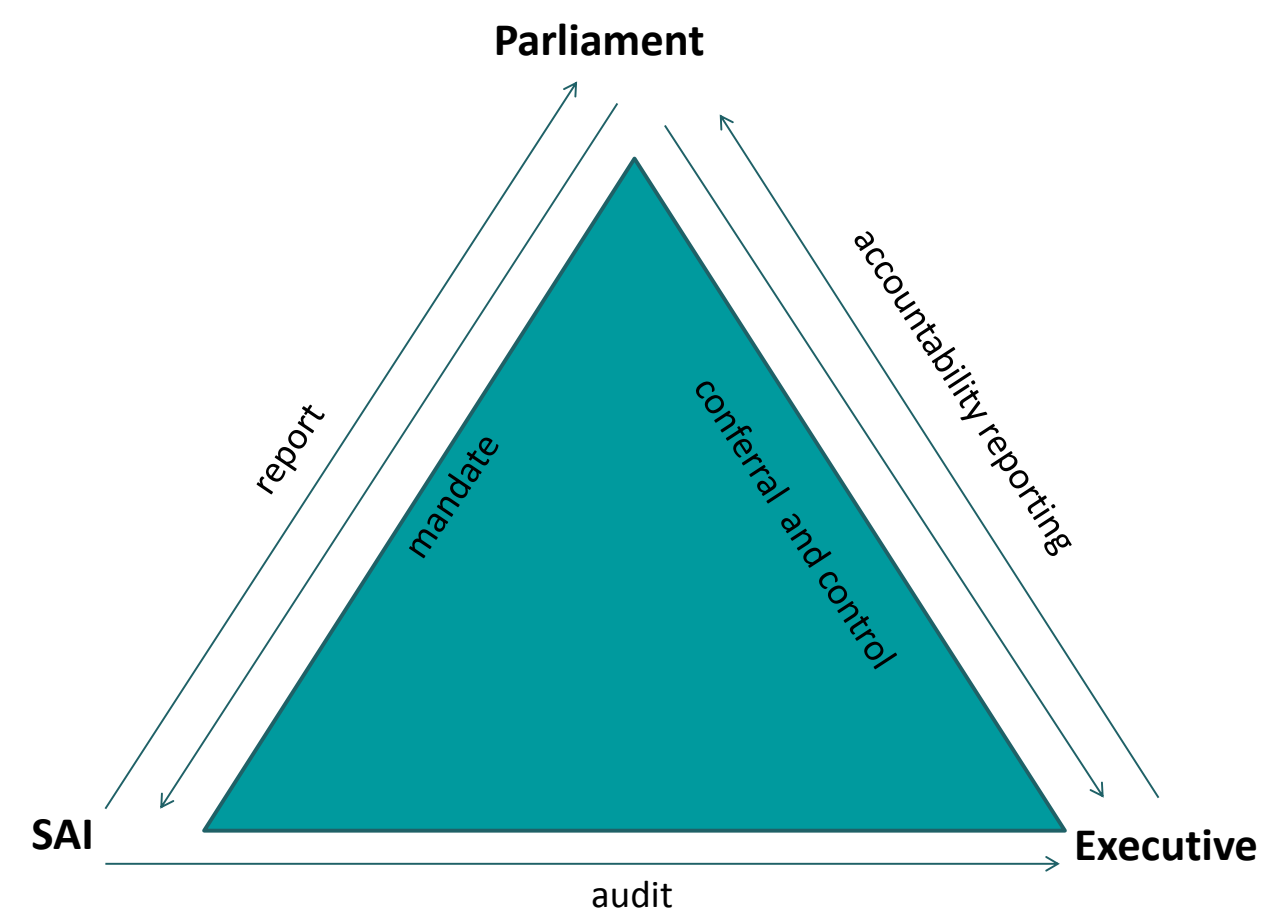

Source: Stapenhurst, Rick et al. (2014), Following the Money: Comparing Parliamentary Public Accounts Committees, London.

The accountability triangle is based on the principle that: parliament adopts the state budget and authorises the executive to implement the budget (conferral); the executive reports on the implementation of the budget to parliament; the independent audit institution, in line with its constitutional/legal mandate, audits the budget implementation and reports to parliament; and that parliament, on behalf of the citizens, holds the executive to account (control) and, in some countries, provides formal discharge. All parts of the triangle have to play their role to support the effective accountability for the use of public resources.

Parliaments have a duty to oversee the implementation of the budget they have adopted. This duty stems from the mandate parliament received from the electorate. Parliament has a responsibility to ensure that the executive has used the resources effectively, efficiently and economically and as intended in the budget, drawing on the work of the SAI. It is not sufficient to rely on the executive to respond effectively to the findings and recommendations of the SAI. That would negate the fundamental duty of parliament to exercise control over the executive.

In fulfilling their role within the system of accountability it is important for SAls to consider how they ensure that their work is relevant, adds value and has impact, not only by reviewing and reporting on what has happened but also by looking forward, identifying where improvements can be made, and promoting good practice. In this way public sector audit contributes to improved standards of governance, better management and decision making, and more effective use of public money. 
The ISSAIs, along with other standards and principles, provide a framework for and guidance to SAIs. They cover what the SAI should or could consider when analysing the possibilities for creating and enhancing impact, and when engaging with parliament. The rest of this chapter describes the key expectations set out in the relevant standards and guidance about how SAls report to and engage with parliaments, and the following chapter covers what is expected from parliaments when handling SAI reports and communicating with SAIs. The detailed requirements of the standards and principles are set out in Annex 1.

\subsection{Expectations for SAls}

The mission of an SAl is to report and provide assurance on the use of public resources by government, and as a result contribute to a well-functioning accountability system. As described in the previous section the relationship of an SAI with parliament is a fundamental element in delivering this mission effectively, ensuring the work of the SAI has impact and enhancing accountability. Throughout the ISSAIs and other relevant standards there are certain principles and requirements that an SAI must meet in order to comply with the professional standards for SAls. Table 1 provides an analysis of the key requirements for an SAI in its relationship with parliament.

Table 1. SAI standards and principles for effective relationships with parliament

\begin{tabular}{|c|c|c|}
\hline & Requirements & Reference \\
\hline \multirow[t]{4}{*}{ Reporting } & Reports are submitted to parliament and published. & $\begin{array}{l}\text { ISSAI } 1 \text { Section } 16 \\
\text { ISSAI } 10 \text { Principle } 7 \\
\text { ISSAI } 12 \text { Principles } \\
2,3,4 \\
\text { ISSAI } 20 \text { Principle } 7 \\
\text { The Principles of } \\
\text { Public } \\
\text { Administration, } \\
\text { Principles } 15,16^{4}\end{array}$ \\
\hline & $\begin{array}{l}\text { Appropriate communication tools are used to facilitate access and enhance } \\
\text { understanding of reports. }\end{array}$ & $\begin{array}{l}\text { ISSAI } 12 \text { Principle } 4 \\
\text { ISSAI } 20 \text { Principle } 8\end{array}$ \\
\hline & Provide relevant timely and objective information to the legislature. & ISSAI 12 Principle 3 \\
\hline & $\begin{array}{l}\text { Audit reports identify themes, common findings, trends, root causes and audit } \\
\text { recommendations, and are discussed with key stakeholders. }\end{array}$ & ISSAI 12 Principle 3 \\
\hline \multirow{4}{*}{$\begin{array}{l}\text { Communication } \\
\text { Role and Work } \\
\text { of SAls }\end{array}$} & $\begin{array}{l}\text { Establish good working relationships, communication policies and procedures in } \\
\text { liaison with parliament. }\end{array}$ & \multirow[t]{4}{*}{$\begin{array}{l}\text { ISSAI } 12 \text { Principle } 3 \\
\text { ISSAI } 20 \text { Principle } 7\end{array}$} \\
\hline & Engage with parliament and its committees and raise awareness about SAI's role. & \\
\hline & Assist parliament in understanding audit reports. & \\
\hline & $\begin{array}{l}\text { Provide advice on how SAI audit findings and opinions might be used to the } \\
\text { greatest effect. }\end{array}$ & \\
\hline $\begin{array}{l}\text { Communication } \\
\text { Relevance to }\end{array}$ & $\begin{array}{l}\text { Be aware of the expectations of stakeholders and responsive to their views, } \\
\text { without compromising independence. }\end{array}$ & ISSAI 12 Principle 5 \\
\hline
\end{tabular}

OECD (2014), The Principles of Public Administration, OECD, Paris, http://www.sigmaweb.org/publications/PrinciplesPublic-Administration-Nov2014.pdf 


\begin{tabular}{|c|c|c|}
\hline \multirow[t]{2}{*}{ Stakeholders } & $\begin{array}{l}\text { Ensure that stakeholders' expectations and views are factored into } \\
\text { organisational and audit planning. }\end{array}$ & ISSAI 12 Principle 5 \\
\hline & $\begin{array}{l}\text { Assess whether stakeholders believe that they are effective and contribute to } \\
\text { improvements in the public sector. }\end{array}$ & ISSAI 12 Principle 7 \\
\hline \multirow[t]{3}{*}{$\begin{array}{l}\text { Communication } \\
\text { Other }\end{array}$} & $\begin{array}{l}\text { Communication contributes to stakeholders' awareness of the need for } \\
\text { transparency and accountability in the public sector. }\end{array}$ & ISSAI 12 Principle 3 \\
\hline & Periodic assessment of whether the SAI is communicating effectively. & ISSAI 12 Principle 3 \\
\hline & Contribute to the debate on improvements in the public sector. & ISSAI 12 Principle 7 \\
\hline \multirow[t]{2}{*}{ Follow-up } & Submit follow-up reports to parliament. & $\begin{array}{l}\text { ISSAI } 10 \text { Principle } 7 \\
\text { ISSAI } 12 \text { Principle } 3 \\
\text { ISSAI } 20 \text { Principles } \\
3,7\end{array}$ \\
\hline & Monitor and follow-up on recommendations from SAI and parliament. & $\begin{array}{l}\text { ISSAI } 10 \text { Principle } 7 \\
\text { ISSAI } 20 \text { Principle } 3 \\
\text { The Principles of } \\
\text { Public } \\
\text { Administration, } \\
\text { Principle } 16\end{array}$ \\
\hline \multirow{2}{*}{$\begin{array}{l}\text { Reporting } \\
\text { Performance }\end{array}$} & Submit an annual activity report to parliament. & ISSAI 10 Principle 3 \\
\hline & $\begin{array}{l}\text { SAls should be subject to external scrutiny and report the results to } \\
\text { stakeholders. }\end{array}$ & $\begin{array}{l}\text { ISSAI } 12 \text { Principle } 8 \\
\text { ISSAI } 20 \text { Principles } \\
7,9\end{array}$ \\
\hline
\end{tabular}

\subsubsection{Reporting to parliament - the foundation of the relationship with parliament}

The founding principles for the work of SAIs as contained in ISSAI $1^{5}$ (The Lima Declaration) and the prerequisites for SAI independence in ISSAI $10^{6}$ (The Mexico Declaration on SAI Independence) set out the underlying expectations/requirements for SAls to develop effective relationships with parliament.

The Lima Declaration, which was endorsed in 1977, set the underlying expectation for SAls' relationship with parliaments for many years. Section 16 of the Lima Declaration states that SAls should "be empowered and required to report to parliament and to publish its reports". It also states that publication of reports will enhance the opportunities for enforcing the findings of SAls. This was reinforced by ISSAI 10, which was endorsed at the International Congress of Supreme Audit Institutions (INCOSAI) ${ }^{7}$ in 2007. Principle 7 of ISSAI 10 states that SAls should submit reports to the parliament ${ }^{8}$ for review and follow-up on specific recommendations for corrective action, that SAls should have their own internal follow-up system to ensure that audited entities address their observations and recommendations, including those made by the legislature, and that SAls should submit their follow-up reports to the parliament for consideration and action.

ISSAI 1, The Lima Declaration (endorsed 1977), available at http://www.issai.org/en us/site-issai/issai-framework.

ISSAI 10, The Mexico Declaration on SAI Independence (endorsed 2007), available at http://www.issai.org/en us/siteissai/issai-framework/2-prerequisites-for-the-functioning-of-sais.htm.

Which is held every three years.

$8 \quad$ Although differences may exist between the concepts "legislature" and "parliament", for our purpose in this paper we use these terms interchangeably. Laver, M. (2008), Legislatures and parliaments in comparative context, in Weingast, B. and Wittman, D. (eds), Oxford Handbook of Political Economy, Oxford University Press, Oxford. 
ISSAI 1 and 10 therefore set the context for the core relationship that SAls should have with parliament. The ISSAIs have subsequently been developed providing further direction and guidance on various aspects of this relationship and the expectations that are placed on SAls in developing and maintaining it. In particular ISSAI $12^{9}$ (The Value and Benefits of SAIS), and ISSAI $20^{10}$ (Principles of Transparency and Accountability) provide significant further elaboration on the expectations or requirements for SAls to meet in their relationships with parliament (and other stakeholders).

In respect of reporting to parliament ISSAI 12, states for example, that "SAls should submit audit reports, in accordance with their mandates, to the legislature or any other responsible public body, as appropriate."

The standards also set expectations around the quality of the information that SAls report to parliament. They indicate that the information provided should be relevant, objective and timely. They also say that reports should highlight themes, common findings, trends, root causes and recommendations. Advice on the findings so that they can be used to greatest effect, for example through the provision of Good practice guidance, is also encouraged.

The Principles of Public Administration (2014) developed by SIGMA in partnership with the European Commission (EC), define what constitutes good governance in practice and sets out the main requirements to be followed by countries' public administrations during the EU integration process. Within the area of public financial management and audit they meet the requirements of Chapter 32 of the EU acquis. They set out under sub-principle 15.8 the fundamental expectation of an SAl's relationship with parliament: "The Supreme Audit Institution is empowered and required by the Constitution to report its findings annually and independently to the Parliament or any other responsible public body and this report is published."

Finally, one of the dimensions under the Framework for assessing public financial management $\left(\right.$ PEFA $\left.^{11}\right)$ Performance Measurement Framework relates to external audit and the work of SAls. One of the four key areas assessed is reporting to parliament.

\subsubsection{Communication - understanding the role and work of SAls}

Building on the underlying expectations established in the Lima and Mexico declarations, the ISSAls express the expectation that an SAI will develop effective communication lines and relationships with parliament and its relevant oversight committees. Specifically, ISSAI 12 indicates that "SAIs should develop professional relationships with relevant legislative oversight committees and audited entities' management and governing boards to help them better understand the audit reports and conclusions and take appropriate action." This is also indicated in ISSAI 20 which states that "SAIs maintain a strong relationship with relevant parliamentary committees to help them better understand the audit reports and conclusions and to take appropriate action."

ISSAI 12, The Value and Benefits of SAIs - Making a Difference to the Lives of Citizens (endorsed 2013), available at http://www.issai.org/en us/site-issai/issai-framework/2-prerequisites-for-the-functioning-of-sais.htm. issai/issai-framework/2-prerequisites-for-the-functioning-of-sais.htm. 
Therefore the expectation is that SAls will develop a relationship with parliament to ensure that it understands the role of the SAI and its audit reports. This clearly indicates that today, according to the standards, formal submission of reports is not sufficient for stimulating adequate follow-up and action. SAls need to do more to explain their role and the work they do, provide briefings on reports and other matters, and be pro-active in engaging and explaining their work. They should develop and implement an effective communication strategy to ensure their work can have impact, and support good governance. As ISSAI 12 states, SAls should communicate in a manner that:

- increases stakeholders' knowledge and understanding of the role and responsibilities of the $\mathrm{SAI}$ as an independent auditor of the public sector;

- contributes to stakeholders' awareness of the need for transparency and accountability in the public sector;

- ensures understanding of the SAl's audit work and results.

ISSAI $21^{12}$ presents some examples of Good practices including SAls presenting the findings of reports to parliamentary committees, providing orientation and training in financial management for members of parliament, providing a guide on examining public spending for parliamentarians, and holding informal meetings with the chairs and members of parliamentary committees to explain the role and mandate of the SAI and receive feedback on the needs of various committees.

\subsubsection{Communication - relevance to stakeholders}

In undertaking their missions and ensuring that their work adds value and has impact, the ISSAls firmly set out the importance of ensuring the work of the SAI is relevant to parliament, citizens and other stakeholders. ISSAI 12 (Values and Benefits of SAls - Making a Difference in the Life of Citizens) provides authoritative guidance about this:

SAls can show their relevance by appropriately responding to the challenges of citizens, the expectations of different stakeholders, and the emerging risks and changing environments in which audits are conducted. Furthermore, it is important that SAls have a meaningful and effective dialogue with stakeholders about how their work facilitates improvement in the public sector. This enables SAls to be a credible source of independent and objective insight, supporting beneficial change in the public sector.

In this regard, Principle 5 (Being responsive to changing environments and emerging risks), Principle 6 (Communicating effectively with stakeholders) and Principle 7 (Credible source of independent and objective insight and guidance) of ISSAI 12 give clear expectations of SAls in ensuring their work is relevant, which include:

- being aware of the expectations of stakeholders and responding to these;

- responding appropriately to the key issues affecting society when developing their Work programme;

- evaluating changing and emerging risks in the audit environment and responding to these in a timely manner;

ISSAI 21, Principles of Transparency - Good practices (endorsed 2010), http://www.issai.org/en us/site-issai/issaiframework/2-prerequisites-for-the-functioning-of-sais.htm. 
- ensuring that stakeholders' expectations and emerging risks are factored into strategic, business and audit plans, as appropriate;

- engaging with stakeholders and considering their views without compromising independence;

- assessing whether stakeholders believe that the SAI is effective and contributes to improvements in the public sector.

While it is important that the SAls are free to independently develop and determine their Work programme, engagement with parliament and other stakeholders is essential. This ensures that the SAI has identified key issues affecting the public services in its planning and assessment of audit coverage, and delivers a programme that is of relevance and interest to parliament and other stakeholders. Such engagement, combined with robust processes for identifying relevant audit topics within the SAI, should minimise the risk that key issues affecting the public service are ignored, increase the likelihood that the SAI's work has impact, and help develop a relevant and interesting Work programme.

The concern is sometimes that by engaging with parliament and other stakeholders about the Work programme or considering requests for audits, the independence of the SAI is somehow compromised. However, as long as the discretion to ultimately determine its audits or Work programme is clearly the responsibility of the SAI, and that the SAI uses this discretion in considering suggested audit topics, engagement with parliament and other stakeholders in itself should not be seen as a threat to independence.

Therefore ISSAI 12 sets a clear expectation that the SAl should be effectively engaging with parliament (along with other stakeholders) to ensure that parliament's expectations and views are understood, that parliament understands the challenges the SAI may face, and that these are all factored into the SAI's considerations for planning its audit work.

To maintain communication and relevance to stakeholders, the standards also indicate that SAls should:

- contribute to the debate on improvements in the public sector, without compromising their independence;

- facilitate access to their reports by all their stakeholders using appropriate communication tools;

- establish communication policies and procedures in liaison with parliament;

- periodically assess whether stakeholders believe the SAI is communicating effectively.

\subsubsection{Follow-up}

The standards set expectations for SAls to follow up on the observations and recommendations contained in the SAI's reports, and reporting the outcomes. ISSAIs 10, 12 and 20 specifically refer to follow-up. An expectation is also set on following up on recommendations made by the parliament, one of its commissions, or the auditee's governing board, as appropriate.

The SAI's overall responsibilities on reporting therefore include that an SAI will report to parliament (and other stakeholders) on the results of its work to assess whether the government or its entities have taken appropriate action on the recommendations of the SAI. 
Effective follow-up of SAI reports is also one of the areas considered under the external audit dimension in the PEFA Framework, with the rating achieved being driven by the level of effective and timely follow-up on the results of the SAl's reports.

\subsubsection{Reporting on SAI performance}

SAls should be accountable for their own performance and use of public resources. The standards set expectations around assessing and reporting of an SAI's performance. They give the expectation that the SAI will report on its performance to parliament and other stakeholders, including financial statements, and that these reports will be subject to external audit or scrutiny, the outcomes of which are also reported to stakeholders. For example ISSAI 10 states that "SAls should submit an annual activity report to the Legislature...." and ISSAI 12 states "SAls should be subject to independent external scrutiny, including external audit of their operations, and make available these reports to stakeholders."

The standards also state expectations that SAls will assess whether stakeholders believe that they are effective and contribute to improvements in the public sector, and whether the SAl is communicating effectively. Thus they should also be engaging and consulting with parliament to assess whether they are achieving this.

Finally with respect to the performance of SAIs, the INTOSAI Working Group on the value and benefits of SAls developed a performance measurement framework $(P M F)^{13}$ that includes a dimension on communication with the legislature, the executive and the judiciary. The framework has been tested in several INTOSAI regions. The final version was endorsed during the 2016 INCOSAI in Abu Dhabi. The PMF sets out the dimensions of Good practices on communication with the parliament, against which the performance of SAI can be measured. They cover the areas that are highlighted in this section, and mainly follow the ISSAIs. Details are provided in Annex 2.

\subsection{Concluding remarks}

The expectations placed on an SAI for engaging with parliament are clearly set out through the ISSAIs and other related guidance in order for it to report and provide assurance on the use of public resources by government, and as a result contribute to a well-functioning accountability system.

There is a view that the expectations set through the ISSAls are high, and are what you would expect of SAls in well developed countries with mature democracies. However this does not undermine their relevance to all SAls, as they should aspire to delivering their mandate professionally and with increasing impact. And for countries with aspirations of EU accession these are the expectations they should be looking to achieve, tailored appropriately to the particular circumstances of each country.

13 SAI Performance Measurement Framework, December 2016, available at http://www.idi.no/en/idi-cpd/sai-pmf. 


\section{EXPECTATIONS FOR PARLIAMENTS}

In principle, parliaments are sovereign in the way they deal with SAI reports, apart from legal requirements in some countries. As a result there is not the same plethora of standards or principles available to guide parliaments in the development of their arrangements for handling SAI reports or for their engagement with SAls. Consequently, SAls lack an authoritative set of principles they can refer to when asking parliament to pay due attention to SAI reports to enhance their impact. However, The Principles of Public Administration, in conjunction with the requirements of Chapter 32 of the acquis and the PEFA Framework for assessing the status of public financial management ${ }^{14}$, provide key principles that provide a starting point.

\subsection{Formal mechanisms for dealing with SAI reports}

The key focus of these documents is that there is a formal mechanism for the parliament to consider SAI reports and that parliament pays due attention to the reports in seeking to hold the government to account. These two expectations can be considered as minimum, generally acknowledged principles.

The PEFA Framework takes this expectation further, with consideration of the:

- timeliness of examination of audit reports by parliament;

- extent of public hearings on key findings undertaken by parliament;

- issuance of recommended actions by parliament;

- implementation by the executive, and systematic follow-up by parliament.

There are very few other standards to draw on. No official standards refer to the existence of a dedicated committee dealing with SAI reports and tasked with the day-to-day communication with the SAl, let alone a parliamentary audit committee, such as a public accounts committee. However, often such a dedicated committee is considered to be an advantage for effectively dealing with SAI reports. Ultimately it depends on the way a parliament organises its own work and procedures, including the manner in which a parliament delegates part of its work to its committees.

Although the guidance provided by standards is fairly limited, there are a number of research papers prepared on financial oversight by parliaments ${ }^{15}$. These provide further guidance on what could be considered Good practice in parliamentary financial oversight. Key examples of Good practice for any type of dedicated committee include that:

- it should have a clearly defined mandate with a wide scope;

- sufficient staff and resources should be available to support the committee;

- meetings of the committee should be held in public;

14 PEFA (2016), Framework for assessing public financial management, PEFA Secretariat, Washington, D.C., https://pefa.org/sites/default/files/PEFA\%20Framework English.pdf.

15 Buzaljko, Karolina et al. (2010), Public Financial Oversight; a Comparative Analysis of Parliamentary Committees Across Europe, master's thesis, Maastricht Graduate School of Governance, Maastricht, https://governtransparently.files.wordpress.com/2013/04/wbi-final.pdf. 
- clear follow-up procedures of the parliament on audit reports should be established, complementary to those of the SAl;

- training should be provided for members at the beginning of their term and during their mandate.

There are more studies available that provide additional guidance on Good practices specifically for parliamentary audit committees.

\subsection{Expectations for parliamentary audit committees (PACs)}

A parliamentary audit or accounts committee is one of the methods parliaments can choose for dealing with SAI reports. Beyond legal regulations at national level, including constitutional provisions, parliamentary laws or the standing orders of parliaments, there are no binding European or international conventions that would set expectations on how PACs structure their relationships with SAls. Parliaments enjoy considerable discretion in how to engage with SAls. There are however comparative surveys $^{16}$ that provide ample evidence for country diversity in how PACs are institutionalised and, more importantly in this context, how they interact with SAls.

Although there is no single authoritative source summarising parliamentary "Good practice" for organising the relationship between a PAC and an SAI, it is possible to identify a core of broadly accepted operational principles. These emerge from the comparative studies, but also from a diverse range of other relevant documents. They include:

- SIGMA's Principles of Public Administration, particularly about public financial management (especially Principle 16), in conjunction with the requirements of Chapter 32 of the acquis;

- the 2016 PEFA, Framework for Assessing Public Financial Management ${ }^{17}$ which, in its Pillar VII, contains indicators for the quality of legislative scrutiny of audit reports;

- SIGMA's 2002 Paper No. 33 on Relations Between SAls and Parliamentary Committees ${ }^{18}$;

- the 2015 paper Cooperation for Accountability: The Supreme Audit Institution and Public Accounts Committee Communication Toolkit, published by German Deutsche Gesellschaft für Internationale Zusammenarbeit (GIZ) $\mathrm{GmbH}^{19}$ on behalf of the $\mathrm{EU}$ and the German Federal Ministry for Economic Cooperation and Development ${ }^{20}$.

The core substantive concerns of the requirements and recommendations of these documents that are relevant for the present paper relate to two main issues: 1 ) the powers and resources of PACs; and 2), how the PACs deal with information provided by SAls.

Scottish Parliament (2003), Parliamentary Audit: The Audit Committee in Comparative Perspective, or Stapenhurst, Rick et al. (2014), Following the Money: Comparing Parliamentary Public Accounts Committees, Pluto Press, London. PEFA (2016), Framework for Assessing Public Financial Management, PEFA Secretariat, Washington, D.C., https://pefa.org/sites/default/files/PEFA\%20Framework English.pdf Publishing, Paris, http://dx.doi.org/10.1787/5kml60vd5x8r-en. https://www.giz.de/. GIZ (2015), Cooperation for Accountability, the Supreme Audit Institution and Public Accounts Committee Communication Toolkit, https://www.giz.de/en/downloads/giz2015-en-gfg-cooperation-accountability.pdf. 


\subsubsection{Powers and resources of PACs}

The legal rights and privileges of the PACs, and their staffing resources, are of critical importance for their ability to make the most of the information provided by SAls and to contribute effectively to the scrutiny, oversight and accountability function of parliament as a whole. Stapenhurst et al. recommend that, among other things, a PAC should:

- have between 5 and 11 members;

- be chaired by a member of an opposition party;

- be appointed for the duration of a parliamentary term;

- have a clear mandate and powers to ensure that recommendations are implemented;

- operate in a non-partisan manner;

- be adequately resourced, with an experienced clerk and competent staff who have appropriate training and access to required skills;

- use the auditor as an expert adviser in all its deliberations.

Similarly, the 2002 SIGMA Paper suggests that a PAC should, when possible:

- act in a "non-political way";

- have a member of an opposition party as committee chair;

- have suitable staff support, which might include the secondment of at least one of the SAI staff to assist the committee in its reporting function;

- keep parliament as a whole fully informed about its findings;

- seek the backing of parliament for its findings and recommendations;

- ensure that their own reports and recommendations are prepared in a timely fashion to help hold government to account.

The PEFA Framework stipulates that "a report on the results of review of the external audit report(s) by any mandated committee should be submitted for consideration (and ideally debated) in the full chamber of the legislature in order to constitute a completed scrutiny" (p. 83).

In essence, the first group of operational principles is intended to ensure that PACs are in a position to take full advantage of the expertise that SAls have to offer. They should be equipped to make a central contribution to the accountability function of parliament as a whole, and enhance the chances of corrective action on the part of government.

The powers and resources of PACs are critically important for SAls, because PACs act as the main interlocutors (or gatekeepers) between SAls and parliament.

\subsubsection{Dealing with information provided by the SAI}

When annual reports provide the basis for (qualified) discharge (or, in rare cases, refusal), the key is that PACs consider the reports in a timely fashion. They should discuss the observations and recommendations of the SAI and produce their own reports in a timely manner, taking SAI 
information into account and setting out concerns clearly; this would increase the likelihood that the executive will act on its observations. As SIGMA Paper No. 33 noted, "It is the practice of many parliamentary committees to draw up, within a reasonable time frame, their own report on an SAI audit report they have received and outline their own recommendations to government, based on the SAI findings and recommendations (...) Parliamentary Committee and SAI reports would be more interesting and readily acceptable by government if they included recommendations that were forward looking" (p. 34).

The Principles of Public Administration state in the public financial management chapter under Principle 5, sub-principle 7 that the relevant parliamentary committee(s) should discuss the annual financial report and the linked SAI report before the discussion on the next (draft) budget (p. 85).

The importance of timeliness in a parliament's own review of SAl audit reports is also stressed by the PEFA Framework, noting that it "is a key factor in the effectiveness of the accountability function", and suggesting that parliamentary scrutiny of an SAI report on the annual financial report should preferably take place within three months of submission. It notes that

Timeliness can be affected by a surge in audit report submissions, where external auditors are catching up on a backlog. In such situations, the committee(s) may decide to give first priority to audit reports covering the last completed reporting periods and audited entities that have a history of poor compliance. The assessment should favourably consider such elements of Good practice and not be based on the resulting delay in scrutinizing reports covering more distant periods (p. 83).

Three further general principles for how parliaments deal with information provided by SAls in the PEFA Framework refer to:

- the transparency of information provided by SAls;

- the openness of PAC deliberations;

- direct interactions with SAI staff.

The first generally accepted principle is that all information provided by the SAI to parliament should be publicly available unless there are overriding considerations.

Secondly, PACs in particular should operate openly whenever practicable. SIGMA Paper No. 33 says, "In many countries, it has been found helpful to allow the general public and media to be present during parliamentary committee (PC) meetings, in order to encourage transparency and awareness of the general public of the matters being addressed" ${ }^{\prime 21}$. The PEFA Framework lays down that, ideally, "all hearings are conducted in public except for strictly limited circumstances such as discussions related to national security or similar sensitive discussions. Committee reports are debated in the full chamber of the parliament and published on an official website or by any other means easily accessible to the public."

Finally, it is generally recognised that while written documents are the prime source of SAI information for parliaments, the latter should seek to include SAI staff in its deliberations. SIGMA Paper No. 33 is explicit in this regard when it states that "it is advisable that the SAI Head and/or 
senior SAl staff be present during PC meetings when SAI audit reports are to be discussed” 22 . Similarly, the PEFA Framework stipulates that "hearings on key findings of external audit reports can only be considered 'in-depth' if they include representatives from the SAl to explain the observations" ${ }^{\prime 23}$.

\subsection{Concluding remarks}

While the level of clearly established principles for parliaments to follow in their scrutiny of SAI reports and engagement with SAls is very minimal, a minimum expectation is that parliaments have formal mechanisms for considering SAI reports, and that these be used to hold the government to account. There is a broad consensus in the literature dealing with the analysis of PACs about how they need to be organised and resourced to take full advantage of the expertise that SAls have to offer. There is also a set of commonly recommended principles about how PACs should deal with the information provided by SAls, notably for regular audit reports. In their communication with parliaments, SAls can - and should - promote adequate parliamentary arrangements for dealing with their work and, in doing so, may refer to these minimum expectations as well as Good practices identified in comparative studies.

Idem.

PEFA (2016), Framework for assessing public financial management, PEFA Secretariat, Washington, D.C., p. 83, https://pefa.org/sites/default/files/PEFA\%20Framework English.pdf. 


\section{RELATIONS BETWEEN SAIs AND PARLIAMENTS: SOME CONTEXTUAL FACTORS}

\subsection{Introduction}

The standards and principles outlined in the previous chapters provide a framework for the relationship between SAls and parliaments. Compliance with the framework needs to consider the cultural, legal and political context of individual countries. There are significant differences among countries in the constitutional and legal set-up of parliaments, SAls, government organisations and budget systems. They all influence the accountability framework and the effectiveness of working relations between SAls and parliaments. This chapter discusses some of the main factors behind the relations between SAls and parliaments.

\subsection{Factors affecting the SAl's relationship with parliament}

\subsubsection{Organisational models}

While the ISSAls set an objective framework for all SAls to follow, SAls have developed within the cultural, legal and political traditions of their individual countries, leading to considerable variation in how they operate. Despite this variation, however, most SAls broadly follow one of three models:

- Office (Parliamentary/Westminster) Model

- Judicial (Napoleonic) Model

- Board (Collegiate) Model

In the Office Model, an SAl is generally led by a single head (Auditor General) who is sometimes an officer of the parliament, as is the case in the United Kingdom (UK), implying a close relationship to parliament. The professional staff tend to have a background in finance and accountancy. Traditionally, SAls under this model have focused on financial audit and in recent years on value for money, and less on compliance with laws and regulations, although in practice some Office Model SAls report extensively on individual cases of non-compliance. In some specific cases, they have the obligation to hand over cases to the prosecutor. They generally have no power or authority to enforce recommendations or initiate sanctions against public officials. In order to have impact, SAls under the Office Model depend on the force of their arguments, credibility as independent sources of objective information, and their engagement with stakeholders, in particular parliament.

For this model to function effectively, the SAI needs the support of parliament to hold the government to account, using the SAl's expertise. The work of the SAI has greater impact when the parliament actively takes an interest in the work of the SAI, and uses this to scrutinise the government's use of public resources and hold it to account. This gives the government greater incentive to act on the outcomes of the SAl's work. However, when the parliament takes little interest or its scrutiny is weak, accountability for the use of public resources can be undermined and the impact of the SAI limited.

In the Judicial Model, the SAl functions as a judicial court. The members are judges with a status similar to judges in other courts, and the professional staff tend to have a legal background. The audit work of judicial SAls has historically focused on verifying and judging the legality of transactions in the financial accounts prepared by public accountants. Through their verdicts, judicial SAls assess the 
legality of the public accountants' actions. They can either discharge them from further liability or enforce their conclusions and impose a sanction on them if they have not complied with the rules governing public financial management. The judicial SAI will generally also provide a report on the overall state account for each budget period to parliament, based on which parliament can grant the government discharge of responsibility for the year if it is satisfied with the management of public funds. Historically, therefore, the SAl holds public officials accountable, with the parliament's involvement generally limited to using the SAI report in undertaking the discharge of the overall state budget account. In current practice, however, most Judicial Model SAls have a mandate that includes financial and performance auditing, and reporting on systemic issues.

In the Board or Collegiate Model the SAI is managed by a college, board or a group of auditors general with the same rank. In some countries, such as Germany, the members of the board or college have similar status as judges in the courts. The focus of work of Board Model SAls (and the background of its staff) has generally been a function of the general legislative and historical context of the country it operates in. There are examples of it having developed along the financial audit line seen in the Office Model, such as in the Netherlands, or from a legal background similar to that of the Judicial Model, for example in Luxembourg. Like SAls under the Office Model, they generally have no power or authority to enforce recommendations or initiate sanctions against public officials. The interest and active role of parliament in using its work is a key factor in whether the work of the SAI has an impact.

Figure 3.1 classifies the SAls within the $28 \mathrm{EU}$ member countries, the 7 Network countries and the $\mathrm{EU}^{24}$ across the broad groups. However, these groups are not homogenous and it is sometimes not easy to place an SAI in one of the three categories as it may have characteristics of more than one model; furthermore, some SAls have evolved from one model to another.

24 The European Court of Auditors (ECA) is the independent external auditor and SAI of the EU. The ECA is also a member of the Network. 
Figure 3.1 Number of supreme audit institutions (SAIs) by organisational model

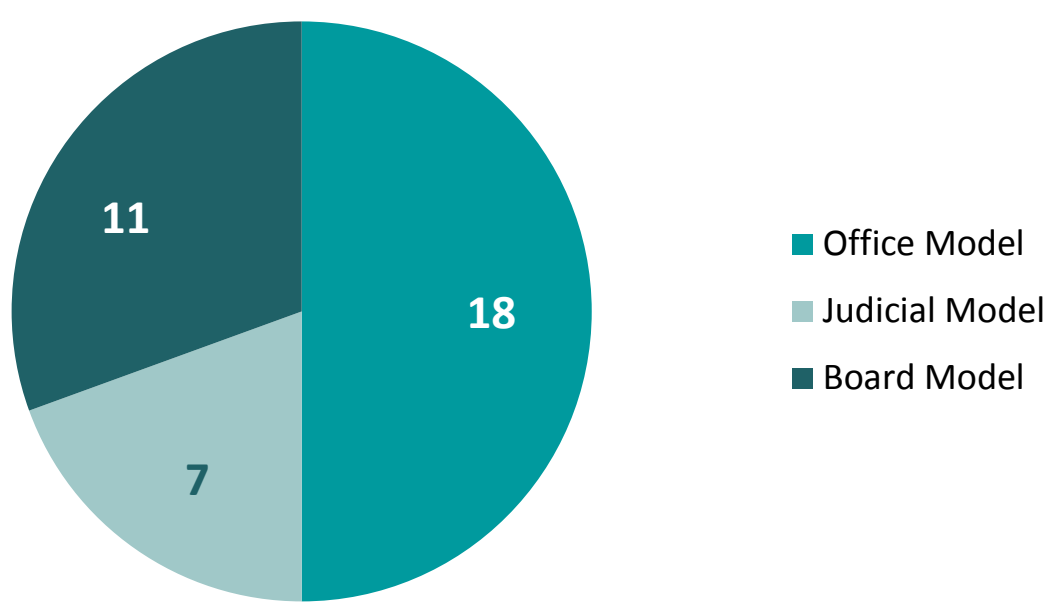

Source: Survey results and websites of supreme audit institutions.

Notes:

Office Model SAls: Albania, Austria*, Bosnia and Herzegovina, Bulgaria*, Croatia, Cyprus, Denmark, Estonia, Finland, Hungary, Ireland, Kosovo, Lithuania, the former Yugoslav Republic of Macedonia, Malta, Poland*, Slovenia* and the United Kingdom.

Judicial Model SAls: Belgium, France, Greece, Italy, Portugal, Spain and Turkey.

Board Model SAls: the Czech Republic, the European Court of Auditors (ECA), Germany, Latvia*, Luxembourg, Montenegro, the Netherlands, Romania, Serbia, the Slovak Republic and Sweden*.

* SAls whose categorisation may be debatable.

\subsubsection{SAl mandate}

As illustrated above, the SAI model and the traditions of the country play a significant role in determining whether the SAl's auditing approach has historically been from a financial or legal perspective, and what its relationship with parliament has been. However, while SAls deliver their audits in a variety of ways with differing emphases, as the SAI community has developed and their standards have become increasingly formalised, many SAls now carry out financial, compliance and performance audits.

For example, while judicial SAls such as the Cour des comptes in France still have their judicial role in judging the legality of transactions undertaken by public accountants, they also conduct financial and performance audits and report the results to the parliament. The work of the Turkish Court of Accounts (TCA) used to be primarily focused on the legality of accounts, but new legislation gave it a broader remit to undertake financial and performance audits.

Under an Office or Board Model, SAls do not have a judicial role regarding the legality of transactions, but they are still likely to undertake some level of compliance audit to ensure that transactions comply with the relevant legal regulations. This may be delivered in combination with a financial audit, as in Sweden, with the scope of the compliance audit focused narrowly on compliance with the appropriations or budget law. Others, like the ECA and the SAI of Poland, may be required to report 
more extensively on issues of non-compliance with legal regulations. They will also generally have a responsibility to report significant contraventions of the law to the appropriate enforcement or prosecutorial authorities. In a few countries, such as Serbia and Montenegro, there are specific responsibilities that the SAI has to investigate and report to prosecutors on low-level issues of noncompliance (misdemeanours) as well as economic and criminal offences.

Financial audit is often quite straightforward to report on, as the audits are generally conducted within an appropriate financial reporting framework, with the objective of providing an opinion (unqualified, qualified, adverse or disclaimed ${ }^{25}$ ) on the reliability and credibility of the financial information. It makes it relatively simple for parliament to be selective in its attention, and to devote time only to the cases of adverse and qualified opinions and disclaimers of opinion. For performance audits this is potentially more challenging, as the interpretation of results, conclusions and recommendations is more open to debate and may have increased political sensitivity. As a result, performance audits are likely to generate increased interest from stakeholders and enable the SAI to have a greater impact, although this entails some risk. In the UK for example, while all reports resulting from its audits are tabled in the Parliament in some form or other, the Public Accounts Committee tends to focus on performance audit reports, including specific investigations; in 2015 it only considered performance audit reports of the SAI. Performance audit is sometimes restricted to performance indicators, as is the case with the TCA.

There is also significant variety in the types of public entities included within the remit of SAls. All SAls by definition examine the accounts and use of resources of central government. But across the SAls of member countries and the Network there are varying levels of involvement in the audit of regional and local governments, municipalities, state enterprises, other public bodies and recipients ${ }^{26}$. For example, in Austria, Croatia and Poland the SAl's remit covers all levels of government, municipalities, state enterprises and all other public bodies. This of course means that the SAI has to conduct audits at these entities and communicate with regional or local assemblies about the results, adding an additional level of complexity.

In other countries, such as Ireland, Sweden and Germany, the SAI is focused on public bodies and possibly state enterprises, as well as central government. In these instances, audits at the regional or local level may be carried out by audit institutions specific to that level of government, or by private audit companies. For example, in the UK there are complex arrangements, with regional audit institutions in Scotland, Wales and Northern Ireland responsible for the audit at regional and local government levels, as well as devolved central government responsibilities in those regions, while in England the audit of local and municipal government is now carried out by the private sector after the recent abolition of the Audit Commission, although certain responsibilities for local government were transferred to the UK SAI.

25 ISSAI 1700, Forming an Opinion and Reporting on Financial Statements (endorsed 2010), http://www.issai.org/en us/site-issai/issai-framework/4-auditing-guidelines.htm.

ISSAI 1705, Modifications to the Opinion in the independent Auditor's Report (endorsed 2010), http://www.issai.org/en us/site-issai/issai-framework/4-auditing-guidelines.htm. 


\subsubsection{Reporting to parliament}

Reporting methods are closely related to the nature of the SAI's mandate and remit, and are another important factor in the relationship between SAls and parliaments. There is wide variety in the type, nature and size of reports sent to parliaments by SAIs. For example, the number of reports submitted by SAls ranges from one or two to hundreds annually. The reports of some SAls capture the main findings from across the range of audit type and auditees; others send reports on individual audits, on a specific subject or topic, or an individual entity. As a result, the nature of the engagement needed between the SAI and the parliament will to an extent reflect the nature of the reporting to parliament.

\subsubsection{Leadership and development}

SAls continue to evolve and develop, and changes within an SAI may naturally impact how it relates to parliament. The personal relationships among the leadership and officials of the institutions is important, and in particular the relationship between the head of an SAI and the chair of the relevant parliamentary committee. Changes to individuals in those positions will have an influence on the work and impact of the SAl, particularly under the Office Model.

The SAI's work environment may change its ability to deliver work that is relevant and of interest to parliament, influencing the relationship. Examples include the development of audit standards, staff turnover and staff development, technical developments such as information and communications technology (ICT) tools, the availability of growing volumes of data and the need to adapt to it, the introduction and development of internal audit, and other changes in the internal control environment. Improvement in the quality of operational and financial management within governments should also lead to more positive outcomes, for example in financial audit reports, likely reducing the public and parliamentarian interest in those reports.

\subsubsection{Parliament's role in determining the SAl's Work programme}

The ability of parliament to influence or determine the Work programme of the SAI will also have a bearing on the nature and type of relationship the SAI has with parliament. In the majority of countries, there are legal provisions for parliament to ask the SAl to examine specific issues or subjects. Even where there is no legal provision, SAls generally indicate that they are happy to receive suggestions or requests from parliament and other stakeholders. However, in nearly every country it is clear that it is ultimately up to the SAI to decide what is in its Work programme. For example, while the Comptroller and Auditor General ${ }^{27}$ in the UK has complete discretion in the discharge of his functions, he is required by law to "take into account any proposals made by the Committee of Public Accounts" when determining whether to carry out any value-for-money examinations. While there is no legal provision requiring requests from other members of parliament or committees to be considered, the SAI does seriously consider the matters raised and some of these requests lead to full value-for-money investigations and reports.

\subsection{Parliamentary arrangements for examining the work of SAls}

There is variety in the specifics of the organisational arrangements, but the results of our survey indicate that parliamentary arrangements for financial oversight generally either involve a specific 
committee that deals directly with the work of the SAI, or rely on the parliament's budget committee. The main distinction between these two models is based on the oversight function these committees fulfil, either ex ante and ex post, or only ex post ${ }^{28}$. Parliamentary committees on audit tend to deal only with ex post financial oversight, but budget committees responsible for handling the work of an SAI are also involved in the approval procedure for budget bills, and therefore also have an ex ante oversight function. Naturally, when the committee is responsible for more than just considering the work of the SAl, its attention and interest will be significantly focused on the scrutiny of the state budget and it will have less time to consider the work of the SAI. However, in some instances when a budget committee has the responsibility, it has set up a special subcommittee functioning for all intents and purposes as a parliamentary committee on audit, for example in Serbia.

While these are the main arrangements that are seen, there are also several others: for example, within Romania's bi-cameral system, there is usually a joint sitting of both committees of the two houses dealing with audit reports and preparing a joint report for the Senate and Chamber of Deputies, and Spain has a joint committee of both houses dealing with SAI reports. By contrast, Sweden clearly departs from the arrangements outlined above, as the SAl's reports are handled by the relevant sectoral or subject committee and not by one specialised committee. In Poland, audit reports are submitted at the same time to the State Audit Committee and the relevant sectoral or subject committee.

In a growing number of countries, in addition to the role played by the audit or budget committee, the sectoral or subject committees are increasingly using and discussing SAI reports, particularly performance audit reports that deal with their policy area.

There is no "one size fits all" for arrangements in parliaments: they depend on how the committee system works, including the possibility of subcommittees, to what extent the plenary delegates parliamentary work to committees, whether joint committee work is possible, whether the debate on the budget is only in the budget committee or sectoral committees as well, and whether government ministers are members of parliament or not. In the latter case, it becomes more important for an audit committee to have a chair belonging to the opposition. A separate audit committee or subcommittee does not necessarily create more capacity for handling SAI reports, but it can help draw more attention to SAI reports and raise the profile and authority of the SAI.

It should be borne in mind that members of parliaments are inclined to be more interested in the future (i.e. policy, budget, legislation) than SAls, which by nature are backward-looking in their audit work. This creates a fundamental challenge for SAls trying to attract attention for their work from parliaments. This stresses the importance for SAls to provide valuable insights and realistic, forwardlooking recommendations based on their audits, as this increases the potential interest of members of parliament, and thus the potential impact of audit work. SAls should consider how they can be relevant for parliaments. At the same time, parliaments should consider what added value SAls can have for their work, in addition to other instruments they use for oversight and control, such as investigations and enquiries, and more traditional instruments such as hearings, interpellations, and oral or written questions to government.

28 The research of Buzalijko et al. on public financial oversight supports the distinction within EU member countries of the roles of parliamentary budget committees and/or specialised committees dealing with audit. Buzaljko, Karolina et al. (2010), Public Financial Oversight; a Comparative Analysis of Parliamentary Committees Across Europe, Maastricht, https://governtransparently.files.wordpress.com/2013/04/wbi-final.pdf. 


\subsection{Government organisation}

The accountability triangle in section 1.1 of this paper shows a simplified model of straightforward relationships among the executive, parliament and the SAl, with the executive considered as one unitary actor of government accountable for every activity to parliament. But the accountability system is often more complicated in reality: for instance, if the organisation of the executive is divided among semi-autonomous agencies, the managers of those bodies are directly accountable to parliament. This may lead to more detailed involvement of both the SAI and parliament with the management of government agencies, and at the same time may reduce attention for more systemic issues.

The accountability triangle also has parliament as a single entity, whereas in reality the accountability system will function through different committees or working bodies, and sometimes be shared between two parliamentary chambers. This division of work within parliament often mirrors the organisational set-up of government, with select committees for all - or at least the main - ministries. For SAls it is important to reflect on how the accountability arrangements affect the effectiveness of communication and reporting lines.

\subsection{Budget and accounting system}

Another factor potentially influencing the relationship between SAls and parliaments is the budget and accounting system. In a budget and accounting system characterised by cash accounting, the audit work on budget execution by the SAI will produce different observations from those resulting from an audit on accrual based accounts. Similarly, the audit of relatively small budget lines will result in different observations from an audit of relatively large budget lines. A separate investment budget needs another audit approach, with another type of observations. Audits of performance-based budgeting will automatically include performance indicators, broadening the scope of an annual audit and resulting in another type of report. Although these variables do not directly influence the relationship between the SAI and parliament, they impact the type of audit report submitted to parliament, potentially setting varying requirements for parliament in dealing with these reports.

\subsection{Dynamics in a political environment}

Elections for parliaments usually take place every four or five years, and sometimes more often because of political considerations. This already implies a dynamic environment with a turnover of members of parliament, changes in the chairs and composition of a dedicated committee, and therefore the need for the SAI to build up new relationships. Procedures may change, and the interest from parliament in specific subjects will change over time as the key issues affecting the country and its electorate evolve and develop. Parliamentary interest in public management issues will fluctuate depending on the issues and challenges of the day, and naturally the contents of policies and programmes may be of more interest to politicians than their implementation by government agencies.

As a result, an SAI needs to be flexible and able to respond effectively to the evolving political environment to ensure that its expertise is considered relevant, without compromising its independence. 


\subsection{Concluding remarks}

The relationship between an SAI and parliament is governed by a large number of factors, from the constitutional and legal setting to the personal relationship between the head of the SAI and the speaker of parliament or the chair of the dedicated committee. It may also be influenced by internal competition in parliament or internal disagreement within the SAI. Relationships between SAls and parliaments are continuously under the influence of these factors; the ability to be flexible, adaptable and responsive to changing circumstances is necessary to maintain effective working relationships. This implies that SAls and parliaments should be in constant communication with each other and continuously assess their relationship to ensure that SAI work is followed up effectively by parliamentarians.

Given the differing circumstances from one country to the next, there cannot be one single model for an effective working relationship between SAls and parliaments. What works in one country at a given moment may not be workable in another, and what works in a country at a given moment may not be workable in that same country at a later point in time. It must be accepted that there is no ideal solution for effective working relationships: it is a process of continuously seeking the best under the circumstances, trying out relevant practices from other countries, and keeping in mind that ultimately the impact of SAI work and its contribution to the overall accountability system are the main objectives. 


\section{ANALYSIS OF WORKING RELATIONSHIPS BETWEEN SAIs AND PARLIAMENTS: GOOD PRACTICES IN EUROPE AND KEY FACTORS FOR EFFECTIVENESS}

\subsection{Introduction}

This chapter analyses features and practices in relations between SAls and parliaments. The information comes largely from the survey and publicly available resources of SAls and parliaments. The chapter builds on the frameworks/standards described in Chapters 1 and 2 and the context described in Chapter 3, to discuss practices across Europe and highlight key factors for effective relations and areas of Good practice.

\subsection{Audit Work programme}

SAls have to be free from direction or interference from parliament or government in the selection of audit issues and in the planning, programming, conducting, reporting and follow-up of their work. At the same time, however, SAls may accommodate specific requests for investigations or audits by parliament or government. They should also ensure that stakeholders' expectations are taken into account when developing their audit programmes, and that stakeholders are engaged and their views are considered.

In practice, a variety of legal and practical arrangements allow stakeholders to request an audit or to have input in the Work programmes of SAls across the EU member countries and the Network. These are summarised in Figure 4.1.

Figure 4.1. Arrangements for engagement on audit topics and the Work programme (WP)

Consultation on WP (Number of SAIs)

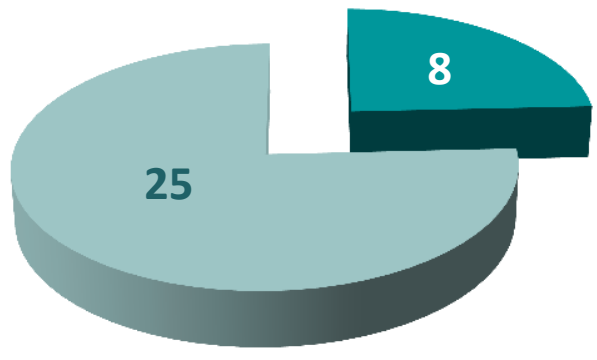

Yes
Legal provision of audit on request (Number of SAls)

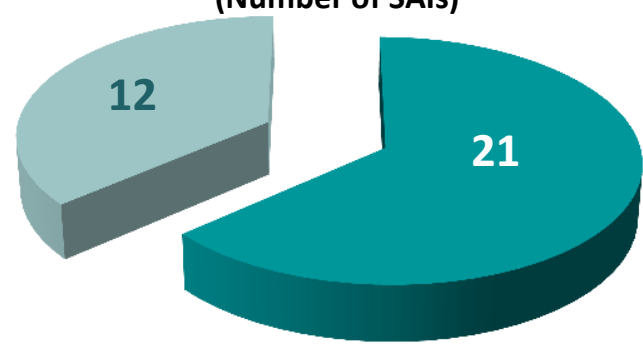

Yes

No

Source: Survey results.

Notes:

SAls with consultation on their proposed Work programme: Albania, the former Yugoslav Republic of Macedonia, Kosovo, Lithuania, Poland, Slovenia, Sweden and the United Kingdom.

SAls with legal provision of audit on request: Austria, Belgium, Bulgaria, Bosnia and Herzegovina, Croatia, the Czech Republic, Denmark, Spain, France, Hungary, Kosovo, Lithuania, Luxembourg, Malta, Poland, Portugal, Romania, the Slovak Republic, Slovenia, Turkey and the United Kingdom. 
The responses to the questionnaire indicate that in 21 countries legal provisions exist for parliament to make a request for an audit, although it is often up to the SAI to take the final decision (9 out of 21) to accept any request. However, in other cases (12 out of 21) the SAI is obligated to accept the request, although the number of audits to be carried out on request may be limited to safeguard the SAl's normal level of operations and avoid an excessive workload. For instance, the Bulgarian SAI has to accept up to five audit requests per year, the Austrian SAI need not accept more than three at a time, and the SAI of Portugal only two per year. If more requests are made, the Portuguese SAI tries to accommodate them in the context of its annual Work programme. In Lithuania the SAI has to accept all audit requests, but in practice an average of just one request is made annually, which does not pose a problem for the SAI. In Slovenia the final decision is left to the SAI, but the Parliament is entitled to submit proposals out of which the SAI is to consider at least five, and at least two must be proposed by opposition parliamentarians. In its annual report the SAI has to account for all proposals made and indicate which ones have been accepted. This practice allows the SAI to select proposals and make decisions about scope and methodology directly.

In some countries the legal provision for requesting audits is limited to members of the audit committee. In Malta, three out of seven members of the audit committee are required to make an audit request. In Ireland the rules of procedure of the Parliament state that the audit committee can make a suggestion for audit, without prejudice to the independence of the SAI.

Where no legal provision exists (12 SAls), in nine cases parliament is not consulted about the Work programme, although this does not mean that suggestions for audits are put aside. For instance, the Latvian SAI actively seeks suggestions once a year, and in Estonia the Parliament collects suggestions to submit to the SAl for consideration. The ECA also takes suggestions and requests from the European Parliament and its committees into consideration when preparing its Work programme for the year. In Germany, all requests from the dedicated committee of parliament are accepted unless they would cause political damage to the SAl or would consume too many resources.

With one exception (Greece, because of the judicial status of the SAI), all SAls surveyed consider suggestions from parliament on possible audit topics or entities to be audited. Some of them even actively seek this input from parliament, thereby meeting the standard for SAls to take views and expectations from stakeholders into account in developing their audit programmes. This should increase the attention parliaments give to SAI reports in general, and assist in creating a greater impact.

In engaging with parliaments and stakeholders, it is important to manage expectations. Among other things, the SAl's mandate, resources and specific expertise may be limiting factors in its ability to meet parliamentary requests or provide high-quality reports within the requested time frame. Dealing with politically motivated audit requests may be a challenge for the SAI, which could find itself in the midst of political turmoil that could damage its image as a professional, objective and independent institution. It may therefore be useful to make an inventory of the investigation instruments potentially available to parliament, including audits by the SAl, and discuss with parliament under which circumstances and conditions an audit or investigation by the SAI would be the preferred option. The SAI could also develop clear criteria for assessing audit requests and share them with the parliament so that it understands the SAl's approach.

Apart from concrete suggestions for an audit topic or entity to be audited, parliaments may also have a role in providing input for longer-term strategic audit plans; for example, the SAI of Latvia has interviewed members of parliament on the budget system to identify areas of interest that could be 
incorporated in longer-term audit planning. This shows that, irrespective of the legal environment, almost all SAls organise input from parliament to demonstrate relevance to stakeholders. SAls need to ensure that this engagement with parliament is effective, and that undertaking mandatory audits on request does not compromise the SAI and its priorities. Table 2 summarises Good practices for the Work programmes of SAls, based on the assumption that SAls enjoy freedom from direction or interference by parliament or government in establishing their audit Work programmes.

Table 2. Good practices for the SAl's Work programme

\begin{tabular}{|l|l|}
\hline Good practices for Work programme \\
\hline Audit request & $\begin{array}{l}\text { Agree with parliament on the procedure for consultation before a formal request is } \\
\text { made. }\end{array}$ \\
\hline $\begin{array}{l}\text { Legal provision to } \\
\text { request an audit }\end{array}$ & $\begin{array}{l}\text { Limit the number of audits on request to be carried out at the same time or during } \\
\text { the year. }\end{array}$ \\
\hline Work programme & $\begin{array}{l}\text { Inform parliament about the Work programme (if this is legally possible). } \\
\text { Organise opportunities for parliament to regularly provide input (through meetings } \\
\text { and interviews). } \\
\text { Liaise with the dedicated committee and other relevant committees. } \\
\text { Follow relevant discussions in parliament for identification of potential audits. }\end{array}$ \\
\hline Strategic plan & Organise opportunities for input by parliament (meetings, interviews, conferences). \\
\hline
\end{tabular}

Source: Survey results.

\subsection{Reporting to parliament}

The survey results confirm that all SAls report to parliament, in most cases on the basis of a constitutional or other legal obligation. In some cases, audit reports - mostly on financial statements - are addressed to auditees, who in turn are obligated to send the financial statements together with the SAI report to parliament, as is the case in the UK. In many countries, the report is published at the same time as it is submitted to parliament, but in some countries specific rules apply: in Luxembourg, for example, a report can only be made public after it has been presented to parliament.

While all SAls report to parliament, the survey clearly demonstrates that there are significant differences among countries:

Germany: The SAI compiles an annual report of the major audit findings and recommendations of its audits conducted during the year. It is a comprehensive report covering all types of audit to some extent, but with a focus placed on performance audit. It may also issue special reports to inform the legislative bodies and the government of matters of particular significance at any time, but the main focus of its audit reporting to the Parliament is the annual report.

Greece: The SAl submits two reports annually, the Annual Report and the Annual Declaration. The Annual Report covers the results of audit operations and observations, comments on detected violations of administrative and financial rules or of the budget, and suggests measures to prevent the recurrence of violations and to reform and improve legislation on the SAl's jurisdiction. The Annual Declaration is delivered on the Annual Financial Statement and the Balance Sheet of the State; it reports on the execution of the budget and whether the accounts are correct. 
Turkey: The SAI sends two types of reports to the Parliament, general and institutional. It provides the Parliament with five general reports per year, covering areas such as execution of the state budget, the financial statistics prepared by the Ministry of Finance, the audit of public entities and the audit of state enterprises. The institutional reports, of which 286 were presented in 2015, report the individual annual institutional audits performed by the SAI. They cover the financial and compliance audits conducted, and in some cases performance audits that examine reported performance indicators. In addition, the SAI sends several hundred reports on local administrations directly to local parliaments.

United Kingdom: The results of the SAl's financial audit work (which includes compliance audit) are reported to Parliament in the form of an opinion published with the annual financial statements of each individual audited entity and, when the Head of the SAl considers it necessary, in an accompanying report. These are usually submitted to the Parliament by the audited entity, although in a small number of cases the SAI will do this directly, with over 350 separate reports presented in 2015-2016. The SAl submits all its performance audit reports directly to the Parliament, of which there were 60 in 2015-2016.

Significant differences exist in the number of reports SAls present to their parliaments: from 2 (in Greece) to 443 (in Croatia), as shown in Figure 4.2. It should be noted that the number of reports simply reflects the mandate, overall Legal framework and capacity of the SAI, and does not in any way give an indication about the quality of reports or the underlying audit work.

Figure 4.2 Number of reports submitted to parliament in 2015

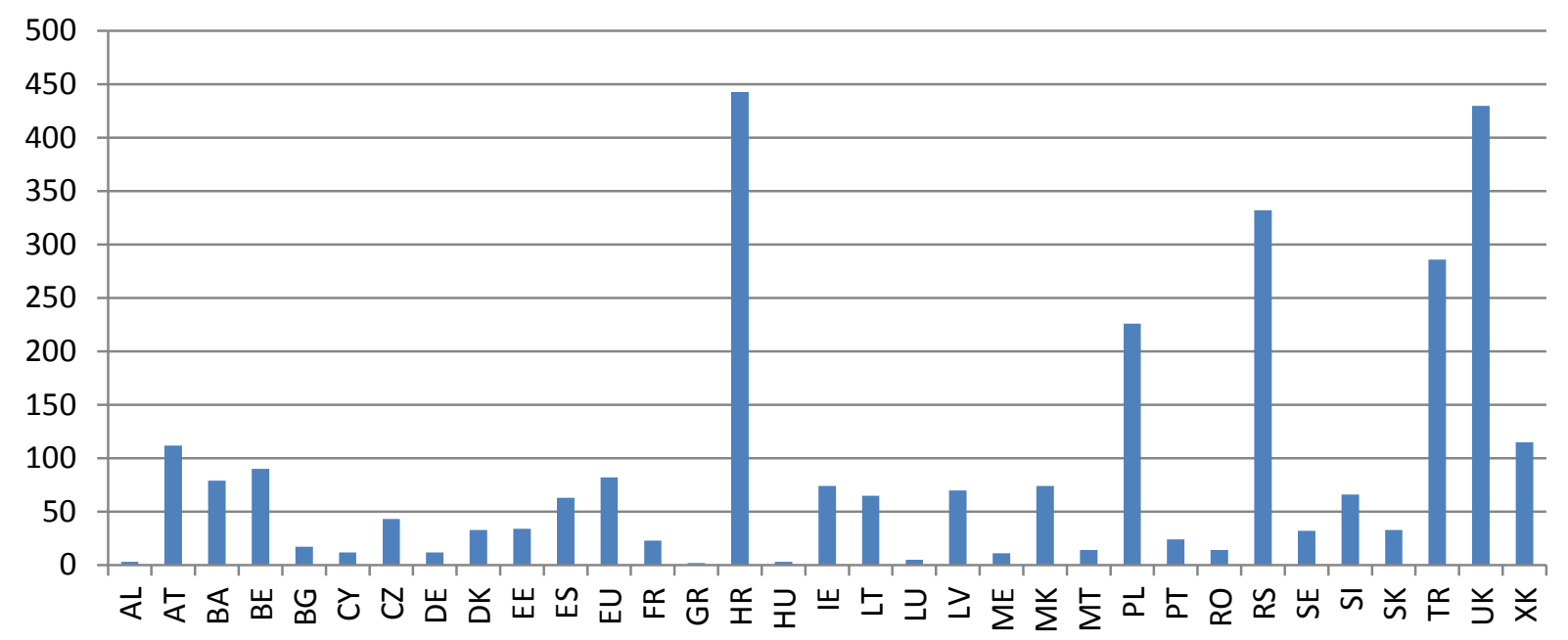

Sources: Survey results and SAI websites.

Note: Reference year for Belgium is 2014.

Abbreviations: AL (Albania), AT (Austria), BA (Bosnia and Herzegovina), BE (Belgium), BG (Bulgaria), CY (Cyprus), CZ (the Czech Republic), DE (Germany), DK (Denmark), EE (Estonia), ES (Spain), EU (European Union), FR (France), GR (Greece), HR (Croatia), HU (Hungary), IE (Ireland), LT (Lithuania), LU (Luxembourg), LV (Latvia), ME (Montenegro), MK (the former Yugoslav Republic of Macedonia), MT (Malta), PL (Poland), PT (Portugal), RO (Romania), RS (Serbia), SE (Sweden), SI (Slovenia), SK (the Slovak Republic), TR (Turkey), UK (the United Kingdom), XK (Kosovo). 
Effective handling of reports by parliaments will be influenced by, among other factors, the number of reports submitted. Legal obligations determine whether all individual audit reports need to be submitted separately or can instead be summarised, for example in the SAI's annual report. The SAI of Montenegro, for example, submits summaries of all reports in SAls annual report, but also provides a selection of individual reports considered essential for consideration by Parliament; this procedure allows attention to be focused on the most important reports.

Another option is to submit all reports, but with advice on priority for parliamentary examination. In the UK the parliamentary audit committee, the Committee of Public Accounts, decides which performance audit reports it will examine based on briefings by the SAI (roughly half the reports submitted), and only examines financial audit reports if the SAI highlights specific issues for discussion. SAls therefore have several options to assist parliament in focusing selectively on the most important reports or issues, the common goal being to develop procedures that help ensure substantive handling of those reports that really require it, in co-operation with parliament. Substantive handling of reports naturally depends on the capacity of parliament, and the distinction between annual reports and special reports needs to be taken into account as well.

There are different ways to submit reports to parliament. Some SAls and parliaments have a rather formal procedure in which the Head of the SAI sends the report to the Speaker of Parliament (the Czech Republic), who then forwards it to the competent committee. Others send reports directly to the dedicated committee (Albania) or even to all members of parliament (EU). In some cases, the parliament distributes reports itself (Croatia), but generally the annual report is presented by the Head of the SAl to the plenary or the dedicated committee. In some instances, there is the opportunity to ask the SAI questions during the presentation, while other SAls give briefings on audit reports that offer greater background and insight. Such briefings can assist parliamentarians and their working bodies to deal with audit reports in a professional manner.

All SAls publish their reports on their websites and many issue press releases when a report is published. Reports often contain summaries to facilitate reading and guide readers to specific topics of interest, and all SAls maintain that their reports contain clear conclusions and recommendations. Some SAls, for example the ECA, have introduced a new type of report based on the entire body of previous audit observations on a certain topic. This allows for higher-level observations and conclusions on systemic issues and their root causes.

The results clearly indicate that there is no single, correct way to meet the reporting requirements of the ISSAls, but a variety of arrangements are needed appropriate to the SAI's context; some Good practices for reporting are summarised in Table 3. No matter how the SAI reports on its work, however, it needs to engage with parliament to ensure it can effectively handle the reports that are submitted. This allows parliament to focus on the key reports, issues or themes brought forward by the SAI, and in this way the SAI can meet the ISSAI objective of ensuring that the parliament considers the relevant areas and examines themes and common findings. 
Table 3. SAl reporting: Good practices

\section{Good practices for reporting}

Submit reports to parliament and publish at the same time.

Make sure reports are distributed among all relevant members/committees.

Offer presentations and briefings on reports.

Use press releases to highlight important issues.

Consider being selective in the reports submitted or give advice on which reports to select for examination.

Consider thematic reports assembling results from previous audits.

Source: Survey results.

\subsection{Communication}

Many of the SAls surveyed have taken initiatives to meet the standards implying that SAls should establish good working relationships with parliament, raise awareness about the role of SAls and assist in understanding audit reports. The SAI of Greece, notwithstanding its judicial status, has organised briefings on reports for two parliamentary committees, as it considers the institutionalisation of such activities as positive for its relationship with the Parliament. Turkey's SAI has developed a new communication strategy addressed to the Parliament as well as other bodies, and the SAI of Belgium has communication experts to assist auditors in drafting clear and understandable reports. The SAI of Latvia communicates about its reporting timetable with the Parliament to allow maximum attention for audit reports, whereas the SAls of Albania, Serbia, Hungary and Lithuania organise conferences and roundtables on specific subjects to which parliamentarians are invited, or have joint workshops. These activities create better understanding and encourage agreement on co-operation procedures. The latter sometimes take the form of memoranda of understanding, as is the case in the former Yugoslav Republic of Macedonia, Hungary and Serbia. The SAI of the former Yugoslav Republic of Macedonia has developed guidance material and a booklet for members of parliament, introducing them to the role and work of the SAI and explaining how to read audit reports, and the SAI of Sweden organises a workshop for members of parliament after each election on the role and activities of the SAI. All SAls have some sort of contact with parliaments, from rather formal once a year to almost daily in an informal manner. Mutual understanding is enhanced through meetings, but can also be attained through interviews with members of parliament, as the SAls of Latvia and Serbia have done. The SAI of Hungary undertakes specific studies on subjects interesting for the Parliament to engage attention.

The survey also highlights that SAI communication activities are becoming more directed towards increasing parliament attention to reports by involving other parliamentary committees (Albania, the ECA, the Czech Republic, the UK), or simply promoting establishment of an audit committee or audit subcommittee (the former Yugoslav Republic of Macedonia, Croatia, Romania, Turkey). Another method that has been used in establishing increased understanding and good working relationships is secondment of SAI staff to parliament, or even reciprocal secondment arrangements. Ireland, 
Sweden and the UK are examples, and the SAI of Kosovo is considering such secondments; Table 4 summarises some examples of Good practice.

Communication is a two-way street: the effectiveness of a SAl's communication policy and activities will depend on how they are perceived and received by parliament, with the dynamics of the political environment being especially relevant. It is therefore important for SAls to continuously update their communication policies, be aware of new opportunities and try new methods, including those arising from technical developments.

Table 4. SAI Good practices in communicating with parliament

\section{Good practices for communication with parliament}

Hold regular meetings with the parliament, supplemented by informal contacts at the working-level.

Co-ordinate agendas and reporting timetables with the parliament.

Organise conferences, roundtables and workshops.

Issue guidance material and booklets.

Organise training / induction on the SAI for new members of parliament.

Agree memoranda of understanding with the parliament on procedures for co-operation.

Establish a communication policy.

Improve understanding through the secondment of staff.

Source: Survey results.

\subsection{Follow-up on previous observations and SAI recommendations}

Follow-up by SAls on observations and recommendations can be divided into three categories. For SAls that have a judicial function, follow-up on verdicts is implemented through the appropriate judicial or disciplinary courts; there is no further role for either the SAI or the parliament. A second category concerns findings of possible fraud or corruption, wherein the SAI must inform the prosecutor's office for further investigation; again, there is no specific further role for the SAI or the parliament, although information about the status of cases submitted to the prosecutor's office is welcomed.

The third category involves audit observations and recommendations resulting from audits. It is clear from the survey results that all SAls monitor the follow-up of observations and the implementation of recommendations made in their reports, as would be expected on the basis of the standards. Many SAls keep an up-to-date database: Bosnia and Herzegovina and Montenegro use an excel file, Bulgaria and Ireland use an electronic register, and specialised software is employed in the former Yugoslav Republic of Macedonia. Many SAls keep this database internal, but some make the information public. In Lithuania, for example, the status of implementation of recommendations is published in real time on the SAl's website, and Serbia is planning to do the same; the SAI of Bulgaria publishes the cases in which an auditee has failed to implement recommendations in time. The Swedish SAI reports annually to the Parliament on the follow-up of observations and recommendations in audit reports, 
and the SAI of Lithuania does the same twice a year. Some SAls distinguish in their records between recommendations that were accepted by the auditee and those that were not, and in Denmark and Latvia the SAls work closely with their respective parliamentary committees in monitoring follow-up and demanding action when auditee response is insufficient.

It is common for SAls to integrate follow-up monitoring into a system of periodically reviewing the implementation of recommendations, reporting on follow-up and programming follow-up audits. For example, the SAI of Bosnia and Herzegovina systematically reports on the implementation of recommendations from previous audits in its reports, and Austria's SAI has a follow-up system incorporated into its annual audit cycle. In the year following the audit, enquiries are made among auditees on the implementation of recommendations: results are published in the SAl's annual activity report and are also used to select topics for focused follow-up audits on recommendation implementation.

Applying this procedure to annual financial and/or compliance audits is relatively easy, but is more complicated for performance audits, as reporting about follow-up on performance audits is usually part of the annual report. For example, in its annual report on the state accounts, the SAI of Portugal reports on the recommendations accepted from the previous report and their implementation. Similarly, in its activity report the ECA reports on the percentage of its recommendations implemented by the EC, but it has also introduced consolidated reports dealing specifically with the follow-up of its recommendations, and systemically pursues its recommendations in its annual report. For the consolidated reports dealing with follow-up on previous performance audit reports, the ECA takes a sample of all recommendations made in a series of reports and analyses the level of implementation. The SAI of Sweden has a similar approach, and submits an annual report covering actions taken on several previous audit reports.

Some SAls have the power to issue binding requests for action by an auditee in response to audit recommendations (for example, Slovenia). In other countries SAls do request an action plan from an auditee or a report on how the auditee has responded to audit recommendations. An interesting provision exists in Cyprus, where an auditee has to provide a statement of compliance on the implementation of recommendations from the SAI with the submission of its draft budget for approval by parliament, linking the implementation of SAI recommendations directly with funding approval. In Hungary, the SAI has the option to initiate disciplinary action against the head of an auditee when its recommendations are not addressed and can also advise that the auditee's budget be reduced, while the Polish SAI is entitled to propose amendments to existing laws to remedy problems it has identified during its audits (de lege ferenda proposals). In Montenegro, the auditee is legally obligated to submit a report on implementation of the SAl's recommendations within the time frame set by the SAI, and similar obligations exist in the former Yugoslav Republic of Macedonia and the Slovak Republic. Table 5 presents some examples of Good practice in SAI follow-up procedures. 
Table 5. Good practices in SAI follow-up procedures

\section{Examples of Good practices in SAI follow-up procedures}

Recommendations are well founded, workable, realistic and concrete.

A monitoring system is established.

The status of recommendations is published.

Implementation of recommendations is reported at fixed intervals.

Monitoring is integrated into the system for planning reviews and follow-up audits.

Specific attention is given to reporting on implementation of recommendations in performance audit reports.

Many SAls see room for the improvement of follow-up procedures by parliaments: according to the survey, 11 SAls (33\%) are critical about the level or effectiveness of parliamentary follow-up on SAI observations and recommendations. A number of parliaments are also reported to have no follow-up procedures at all.

Figure 4.3 Follow-up procedures by SAls and parliaments

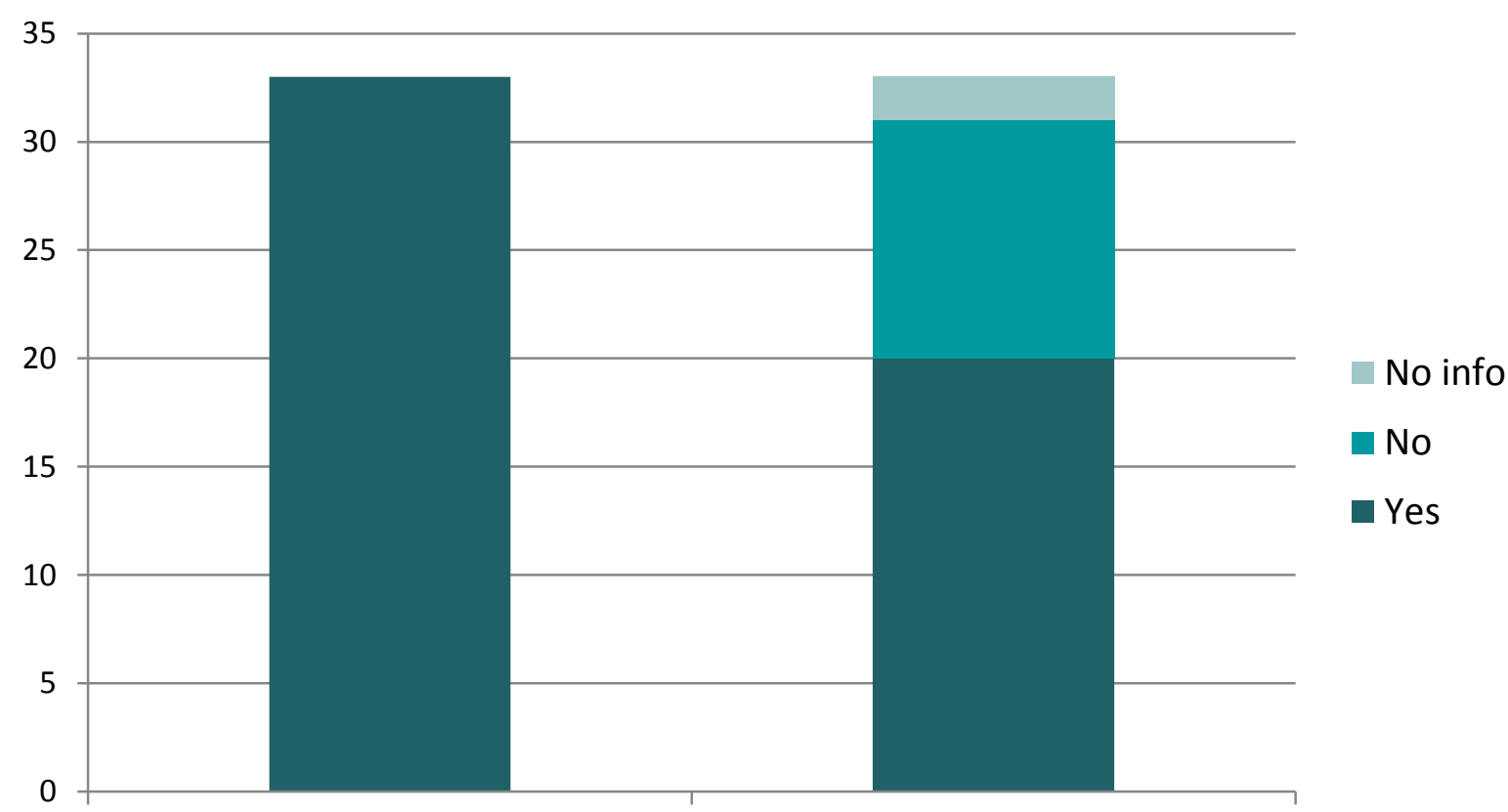

By SAls

By parliaments

Source: Survey results.

In Denmark, Latvia and the UK, the SAI and dedicated parliamentary committee work closely together in monitoring follow-up and demanding measures to be taken by auditees. In Denmark the audit committee asks for statements on SAI reports from the ministers responsible, and subsequently asks the SAI for comments on those statements. In its report to Parliament, the audit committee takes the 
minister's response and the comments made by the SAI into account when proposing its own conclusion; this procedure is illustrated in Figure 4.4.

Figure 4.4 SAI and Parliament follow-up procedures in Denmark

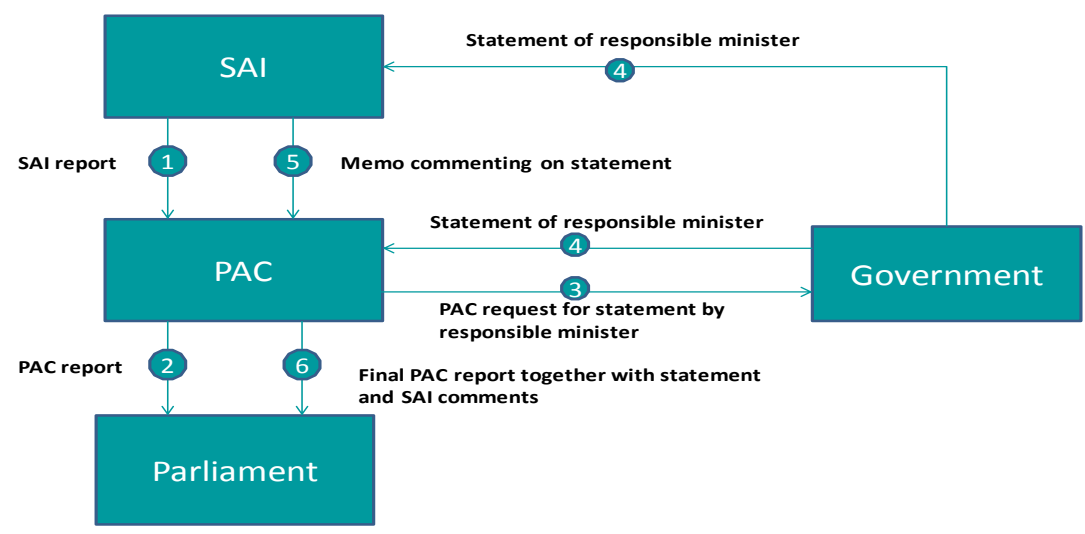

Source: Survey response from SAI of Denmark.

A similar procedure is followed in Latvia, where in an audit committee meeting the auditee provides comments on the SAI report and the recommendations it contains, the SAI provides additional comments or clarifications, and after discussion among the members of the audit committee a schedule is set for the auditee to report on the implementation of recommendations; the SAI is required to provide its opinion on progress. The SAls of Croatia, the former Yugoslav Republic of Macedonia, Romania, the Slovak Republic and Turkey expect that establishment of a separate audit committee in parliament would be beneficial for the effective handling of SAI reports, including following up on observations and recommendations. Based on experiences of countries that already have this type of separate audit committee (see section 4.7), this does appear true, especially for financial and compliance audit reports. The Estonian SAI claims, however, that more impact can be attained through liaison with the government instead of parliament but, although this may be true in specific circumstances, SAls also have the duty to promote accountability, which requires the involvement of parliament.

SAls that are generally satisfied with how parliament deals with audit reports still see room for improvement: the SAl of Bosnia and Herzegovina, for example, is pleased with the way the Parliament deals with financial and compliance audit reports, based on fixed procedures within the Parliament, but would like to have similar procedures for performance audit reports. 
Table 6. Good practices in parliamentary follow-up procedures

Examples of Good practices for follow-up procedures of parliaments

Standard procedures for handling SAI reports are developed.

Hearings with auditees are organised.

An action plan from the government or auditee is required.

Deadlines are set for action plans or measures to be taken.

Sanctions from the SAI or parliament (political, financial and disciplinary) are considered in cases of serious non-compliance with recommendations.

Implementation reports from auditees or the government are required.

Source: Survey results.

\subsection{Reporting on SAI performance}

According to the survey, all SAls apart from Cyprus and Ireland report on their previous year's activities to parliament, either separately in an annual activity report (29 SAls) or in a special chapter in the annual report (Greece, Montenegro). The SAI of Ireland does, however, publish an annual activity report on its website; this demonstrates that all SAls surveyed take their duty to report on their own performance seriously.

In general these activity reports include an account of how resources have been used. The SAI of the UK gives an estimate of savings made in the public sector on the basis of its reports and recommendations. This is a complicated exercise, but the methodology includes agreement by the auditee, which increases the reliability of the results. For 2015, the UK SAI calculated that for every GBP 1 spent on the SAI, it realised GBP 19 of savings. It is a measure of impact and performance, and also facilitates quantitative goal-setting for the next planning period.

Apart from accounting annually for activities and resources, SAls can demonstrate accountability by inviting external reviewers to carry out independent peer reviews and make the resulting reports public. On the basis of a survey carried out by the INTOSAI subcommittee on peer reviews carried out in 2015, 20 out of 36 SAls of the EU and Network countries were subject to a peer review in 19992015 , some of these several times during this time period; given the response to the survey (globally $41 \%$ ), this is probably an underestimation of the real number of peer reviews. Fifteen SAls of the EU and Network countries have published their peer review reports on the INTOSAI Capacity Building Committee website.

Annual activity reports, external scrutiny of SAI accounts by external auditors and periodical peer reviews all contribute to the image of an SAI as a professional, objective, transparent and effective institution. This helps to build trust and authority in the work of the SAI and is therefore helpful in creating or increasing impact. Table 7 presents some examples of Good practice. 
Table 7. Good practices of reporting on SAI performance

\section{Examples of Good practices of reporting on SAI performance}

Audited annual reports on accounts and use of resources are prepared and published.

Annual reports on activities and the implementation of the Work programme are prepared and published

External peer reviews are conducted on a regular basis with public reporting.

Estimates of savings are made for the public sector.

Source: Survey results.

\subsection{Parliaments' handling of SAI reports}

Section 3.3 summarised the main parliamentary arrangements for examining the work of SAls and described the distinct features of budget committees, audit committees and audit subcommittees as the most common organisational solutions for dealing with SAI reports. In an increasing number of countries, subject or sectoral committees are also playing a more important role, stimulated by the SAl or the audit committee itself.

In the Netherlands, for example, the parliamentary committee on audit has a co-ordinating role to actively encourage the involvement of subject committees. However, without procedural safeguards this may create a risk of competition among committees. The SAls of Albania and the UK, and the ECA, are making efforts to involve sectoral committees more in the discussion on SAI reports, for instance by offering briefings on special reports. The SAI of the Czech Republic has concluded that more interest in its reports from sectoral committees would be beneficial, and in the case of Turkey the Parliament has one sectoral committee in charge of hearing audit reports of state economic enterprises and all the other audit reports are handled by the budget committee.

Figure 4.5 summarises the main committee arrangements for handling SAI reports across EU member countries and Network countries. 
Figure 4.5 Number of parliaments according to committee arrangement for handling SAI reports

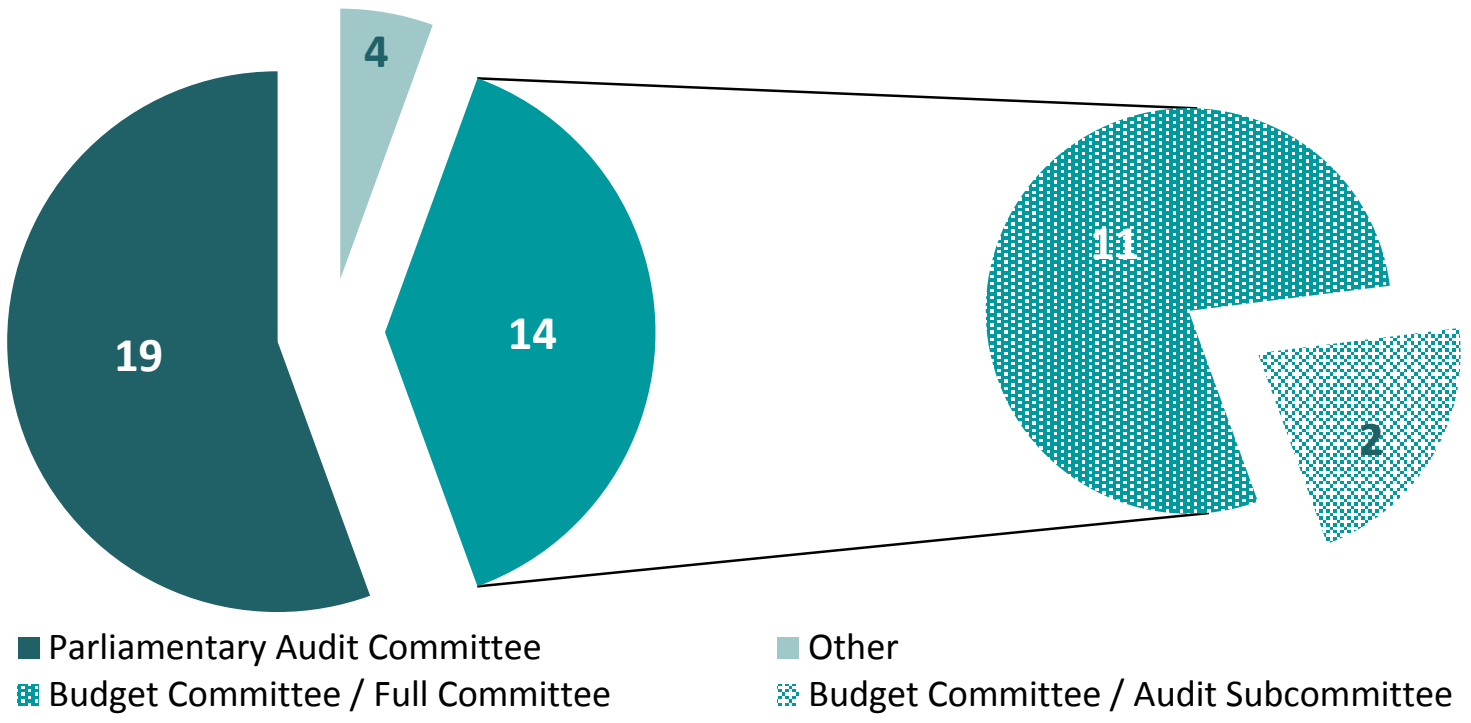

Source: European Parliament (2012), Survey Results and Parliamentary Control of Budget Implementation, http://www.europarl.europa.eu/RegData/etudes/etudes/join/2012/490661/IPOL-JOIN ET(2012)490661 EN.pdf.

Notes:

SAI reports handled by Parliamentary Audit Committee: Austria, Cyprus, the Czech Republic, Denmark, Estonia, the European Union, Finland, Germany, Greece, Ireland, Kosovo, Latvia, Lithuania, Luxembourg, Malta, the Netherlands, Slovenia, Spain, the United Kingdom.

SAl reports handled by full Budget Committee: Albania, Bosnia and Herzegovina, Croatia, France, the former Yugoslav Republic of Macedonia, Hungary, Italy, Montenegro, Portugal, Romania, Turkey.

SAl reports handled by Budget Committee's Audit Subcommittee: Bulgaria, Serbia.

Belgium, Poland, the Slovak Republic and Sweden have other arrangements.

According to the survey, the SAls of Croatia, the former Yugoslav Republic of Macedonia, Romania and Turkey are actively promoting the establishment of a separate audit committee or subcommittee.

In many countries, in addition to discussions at the committee level, debate using the work of the SAI is conducted in the plenary. This usually relates to implementation of the state budget, and is often linked to formal parliamentary decisions on the closure of accounts or discharge of the government for the state budget. Committee discussions are usually preparatory to debate in the plenary, which can then be more focused on the main issues and conclusions to be drawn.

Laying out formal discharge procedures can be beneficial in stimulating accountability by making discharge more important politically and by providing a standard for parliament to hold government to account. In the end, however, a decision to close the accounts or to grant discharge is a political decision, so the way parliament can use discharge depends on the potential consequences; for example, the European Parliament can postpone giving discharge to put pressure on the EC to rectify or remedy errors or systemic failures. If the European Parliament refuses discharge, the political consequence is that the Commission has to step down, sometimes called "the nuclear option". In some countries the consequences of not granting discharges are more limited, for instance forcing 
only the senior manager of an audited entity to step down. In Bosnia and Herzegovina, where discharge is linked to budget approval for the coming year for individual budget institutions, the Parliament can decide to reduce the budget as a sanction if the SAI gives an adverse opinion on the accounts. Figure 4.6 summarises discharge procedures.

Figure 4.6 Number of parliaments with discharge procedures followed in practice

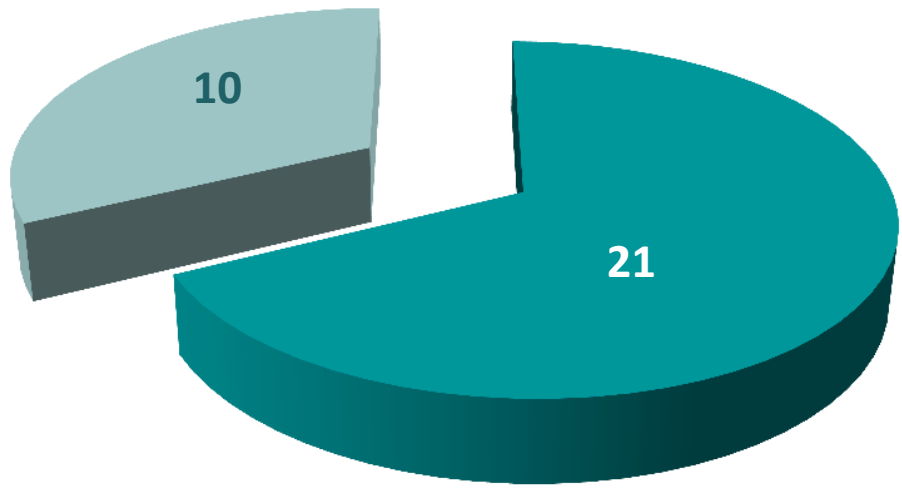

Discharge procedure followed in practice $\square$ No discharge procedure

Source: Survey results.

Notes:

Discharge procedure followed in practice: Albania, Belgium, Bosnia and Herzegovina, Cyprus, Denmark, the European Union, Estonia, France, Germany, Greece, Hungary, Ireland, Latvia, Lithuania, Montenegro, Poland, Portugal, Romania, Slovenia, Turkey, the United Kingdom.

No discharge procedure: Austria, Bulgaria, the former Yugoslav Republic of Macedonia, Kosovo, Luxembourg, Malta, Serbia (but legally possible), the Slovak Republic, Spain, Sweden.

No information on Croatia or the Czech Republic.

Although there can be a difference between discharge and the closing of accounts, Figure 4.6 takes them together.

Discharge is, of course, the last phase in the budget cycle, and results from the discharge procedure should ideally be used as input for approval of the following year's budget.

Many parliaments invite responsible managers or the ministers responsible for entities to their hearings, often together with representatives from the SAI. Allowing auditees to explain their position and giving the SAI the opportunity to highlight key issues and react to arguments put forward by auditees will help parliamentarians make more informed decisions. It should be borne in mind, however, that such hearings use organisational resources, so selectivity is key. Figure 4.7 illustrates the proportion of countries offering this provision. 


\section{Figure 4.7 Number of parliaments with arrangements for hearings with auditee}

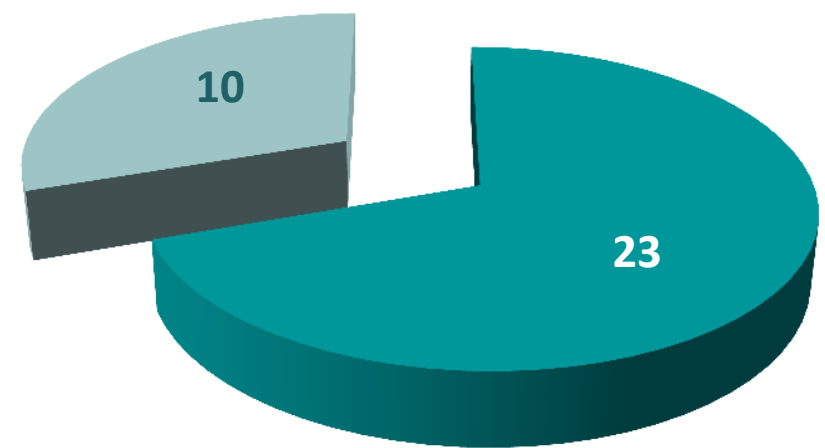

- Hearings with auditee

No hearings

Source: Survey results.

Notes:

Hearings with auditee: Belgium, Bulgaria, Bosnia and Herzegovina, Croatia (only occasionally), Cyprus, the Czech Republic, Estonia, the European Union, France, Germany, Ireland, Kosovo, Latvia, Lithuania, Luxembourg, Malta, Montenegro, Poland, the Slovak Republic (only occasionally), Slovenia, Sweden (only occasionally), Turkey, the United Kingdom.

No hearings: Albania (legally possible), Austria, Denmark, the former Yugoslav Republic of Macedonia, Greece, Hungary, Portugal, Romania, Serbia, Spain.

In a limited number of European parliaments, a system of using rapporteurs for preparing meetings is in place, whereby an individual member-rapporteur is responsible for preparing a committee meeting on a specific SAI report. The member-rapporteur analyses the report, often with direct assistance from the SAI: in the Czech Republic, for instance, the rapporteur can ask the SAI member responsible for the report to help prepare the parliamentary discussion on that report. In the European Parliament, the rapporteur consults with the responsible ECA member and prepares a report for the committee meeting at which the ECA report is tabled for debate. 
Figure 4.8 Number of parliaments with arrangements for rapporteurs

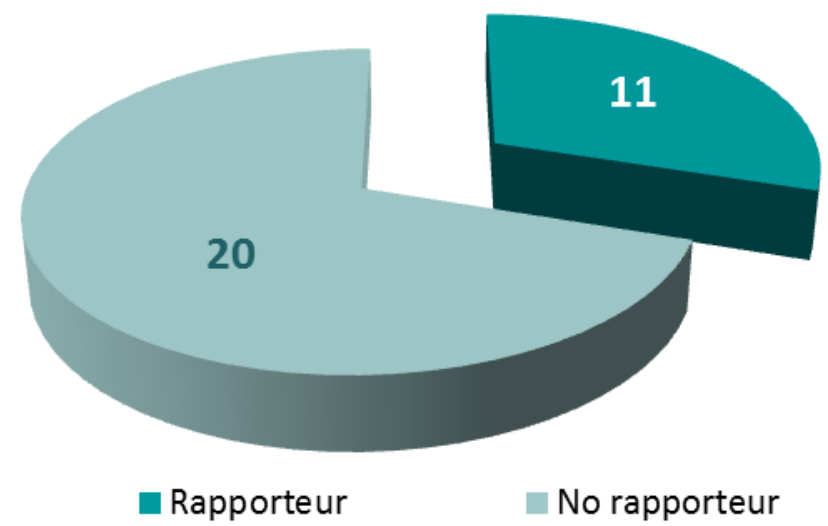

Source: Survey results.

Notes:

Arrangements for rapporteurs: Austria, Belgium, Bosnia and Herzegovina, the Czech Republic, the European Union, France, Germany, Luxembourg, Poland, Portugal, the United Kingdom.

No rapporteur: Albania (legally possible), Bulgaria, Croatia, Denmark, Estonia, the former Yugoslav Republic of Macedonia, Greece, Hungary, Ireland, Kosovo, Latvia, Lithuania, Malta, Montenegro, Romania, Serbia, the Slovak Republic, Slovenia, Spain, Turkey.

No information on Cyprus or Sweden.

Given the wide variety of legal and historic backgrounds of parliaments, it is difficult to summarise success factors in effective working relationships with SAls, or to distil what could be considered Good practice. What works well in one specific context may not work well, or be impossible, in another; however, the survey responses provide some practices worth considering (Table 8).

Table 8. Examples of Good practices for parliamentary arrangements

\section{Good practices for parliamentary arrangements}

Committee responsibilities for SAI reports are adequately organised.

A specialised audit committee or subcommittee has been established.

Sectoral committees are involved in dealing with performance audit reports.

A formal discharge procedure is part of the budget cycle in the context of budgetary oversight.

A rapporteur is assigned for specific SAI reports.

Hearings are held with the auditee.

A schedule is set for parliamentary discussion on SAI reports to make timely conclusions possible.

Sufficient staff and analytical resources are available in parliament.

Source: Survey results. 


\subsection{Concluding remarks}

The survey reveals a wide variety of relationships between SAls and parliaments; most SAls reflect continuously on how these relations can be improved to enhance impact, and they take initiatives for progress. Although parliaments were not involved in the survey, it is known that some parliaments have recently changed their procedures to use SAI reports more effectively, for instance by setting up a special committee or subcommittee, as in Serbia in 2015. This idea had been heavily promoted for several years by the Serbian SAI.

This confirms the general picture that SAls actively look for opportunities to shape and reshape their relationships with parliament to enhance their impact. The dynamic environment, with improvements in the quality of public financial management and the subsequently heavier focus on performance audit by SAls, implies that this will be a continual process. The Good practices assembled in this paper can assist SAls - and parliaments - in finding concrete possibilities to strengthen the effectiveness of their working relationships. An overview of these Good practices, linked to the relevant standards or expectations, is provided in Annex 2, which can be considered a toolkit for assisting SAls and parliaments to find new instruments or procedures. It should be stressed that although SAls are the main target group for this paper, parliaments are also responsible for considering how effective their relationships with SAls are and establishing whether opportunities exist to enhance this relationship.

The role media can play in enhancing impact and raising parliamentary attention for audit reports was outside the scope of this paper, but ISSAI 12, Principle 6-4, states that SAls should interact appropriately with the media to facilitate communication with citizens. In the accountability triangle in section 1.1 citizens are not mentioned, but of course parliament represents the citizens; in this sense, appropriate interaction with the media contributes to the good functioning of the accountability system. SAls should therefore consider how their communication with the media can best improve the effectiveness of their working relationships with parliament. 


\title{
ANNEX 1. INTERNATIONAL STANDARDS AND ACKNOWLEDGED PRINCIPLES FOR RELATIONS BETWEEN PARLIAMENTS AND SAIS
}

\author{
The Principles of Public Administration for EU candidate countries and potential candidates
}

SIGMA developed these Principles in partnership with the EC in 2014, defining what good governance entails in practice and outlining the main requirements for countries to follow during the EU integration process; they are therefore used as a baseline for measuring public administration performance in EU EU candidate countries and potential candidates. Within the area of public financial management, Principles 15 and 16 refer to the role of the SAI:

- Principle 15: The independence, mandate and organisation of the supreme audit institution are established and protected by the constitutional and Legal framework and are respected in practice.

- Principle 16: The supreme audit institution applies standards in a neutral and objective manner to ensure high-quality audits that positively impact the functioning of the public sector.

Principle 16 contains two sub-principles related to an SAI's relationship with parliament: A formal mechanism exists for the parliament to consider SAI reports; and the SAI provides the legislature, and especially legislative committees, with relevant, objective and timely information. The methodological annex has an additional criterion, that parliament is to pay due attention to the reports by holding the government to account.

\section{International Standards of Supreme Audit Institutions (ISSAIs)}

ISSAI 1 - The Lima Declaration, Section 16. Reporting to parliament and to the general public:

"The Supreme Audit Institution shall be empowered and required by the Constitution to report its findings annually and independently to Parliament or any other responsible public body; this report shall be published. This will ensure extensive distribution and discussion, and enhance opportunities for enforcing the findings of the Supreme Audit Institution."

ISSAI 10 - The Mexico Declaration. The existence of effective follow-up mechanisms on SAI recommendations:

"SAls submit their reports to the Legislature, one of its commissions, or an auditee's governing board, as appropriate, for review and follow-up on specific recommendations for corrective action.

SAls have their own internal follow-up system to ensure that the audited entities properly address their observations and recommendations as well as those made by the Legislature, one of its commissions, or the auditee's governing board, as appropriate.

SAls submit their follow-up reports to the Legislature, one of its commissions, or the auditee's governing board, as appropriate, for consideration and action, even when SAls have their own statutory power for follow-up and sanctions". 
ISSAI 12 - The Value and Benefits of Supreme Audit Institutions - Making a Difference to the Lives of Citizens. In 2013, INTOSAI adopted ISSAI 12, a fundamental and ambitious set of standards, partly based on existing INTOSAI standards. ISSAI 12 describes 12 principles of the values and benefits of SAls from the overarching perspective of having impact, linked together through three main objectives:

- strengthening accountability, transparency and integrity of government and public sector entities;

- demonstrating ongoing relevance to citizens, parliament and other stakeholders;

- being a model organisation through leading by example.

The principles were constructed around the fundamental expectation of SAls making a difference to the lives of citizens. Eight of the 12 principles in ISSAI 12 are relevant to the relationship between parliaments and SAls, and each principle is accompanied by a number of standards SAls should be aspiring to comply with. During the development of ISSAI 12, a discussion paper was presented in 2010 at XX INCOSAI in South Africa. Recognition of a SAI as an institution that makes a difference to the lives of citizens was defined as a fundamental requirement, ensuring that government is held accountable for using resources legally and responsibly, for the purposes intended, and economically, efficiently and effectively. This was recognised as the fundamental reason for SAls to exist: to provide assurance and credible information to stakeholders in the interest of the public.

Some of the key standards in ISSAI 12 that have relevance to the relationship between SAIs and parliaments are:

"Standard 12.2.4: SAls should submit audit reports, in accordance with their mandates, to the parliament or any other responsible public body, as appropriate. This standard is similar to ISSAI 1 , section 16 , sub 1 . It is of course essential that in a parliamentary system the SAI submits its reports to the parliament. ISSAI 1 focuses on the legal mandate and obligation, ISSAI 12 takes the mission of an SAI as point of departure.

Standard 12.3.2: SAls should, in accordance with their mandate, provide the legislature, its committees, or audited entities' management and governing boards with relevant, objective and timely information. This standard sets requirements to the quality of the information an SAI provides: objective, relevant and timely. Although the wording refers to the mandate of SAls, the standard implies that whenever possible the SAI should provide information and submit reports to parliament once these are finalised. This is related to ISSAI 20, Principle 8, which states among others: SAls initiate and conduct audits and issue the reports in a timely manner. Transparency and accountability will be enhanced it the audit work and related information provided are not obsolete.

Standard 12.3.5: SAls should develop professional relationships with relevant legislative oversight committees and audited entities' management and governing boards to help them better understand the audit reports and conclusions and take appropriate action. This standard clarifies that formal submission of reports may not be sufficient for stimulating adequate followup and action. SAls need to do more: explain background and context, consider technical briefings, take initiatives, be pro-active, develop and implement an effective communication strategy.

Standard 12.4.3: SAls should facilitate access to their reports by all their stakeholders using appropriate communication tools. This standard refers to ISSAI 20, Principle 8 for further 
guidance. In the related guidance note a number of Good practices are listed, such as holding press conferences, making reports and other information available on the SAI's website.

Standard 12.5.1: SAls should be aware of the expectations of stakeholders and respond to these, as appropriate, in a timely manner and without compromising their independence; Standard 12.5.2: SAls should, in developing their Work programme, respond as appropriate to the key issues affecting society; and Standard 12.5.4. SAls should ensure that stakeholders' expectations and emerging risks are factored into strategic, business and audit plans, as appropriate. These standards highlight the importance of an SAls work being relevant to its stakeholders, that they should be responsive to their expectations and that they should take accounts of such factors in their planning. Without compromising their independence these clearly steer SAls to effectively engaging and communicating with parliament to understand and respond to their expectations.

Standard 12.6.1 SAls should communicate in a manner that increases stakeholders' knowledge and understanding of the role and responsibilities of the SAI as an independent auditor of the public sector; Standard 12.6.2: SAls' communication should contribute to stakeholders' awareness of the need for transparency and accountability in the public sector; Standard 12.6.3: SAls should communicate with stakeholders to ensure understanding of the SAl's audit work and results; and Standard 12.6.5: SAls should engage with stakeholders, recognising their different roles, and consider their views, without compromising the SAl's independence. These standards refer to effective communication with stakeholders, amongst others parliament. The SAI should make sure its work and role are understood, and raise the awareness of the need for accountability. The engagement required obliges the SAI to have an active attitude towards its stakeholders, all geared to enhancing impact. This may include serious consideration of suggestions or requests for potential audit topics.

Standard 12.6.6: SAls should periodically assess whether stakeholders believe the SAI is communicating effectively; and Standard 12.7.4: SAls should periodically assess whether stakeholders believe that they are effective and contribute to improvements in the public sector. Both standards refer to the obligation for SAls to evaluate their overall effectiveness and the effectiveness of their communication in particular. In general, such an evaluation can be carried out in the context of a peer review, but other instruments are possible as well, like questionnaires, interviews or external review by academics or expert consultants. It is important for SAls to know what expectations members of parliament have about the SAI, in order to be able to accommodate, or, if necessary, to manage those expectations.

Standard 12.8.1: SAls should perform their duties in a manner that provides for accountability, transparency and good public governance; Standard 12.8.5: SAls should be subject to independent external scrutiny, including external audit of their operations, and make available these reports to stakeholders; Standard 12.9.1: SAls should adopt and comply with good governance principles and report appropriately thereon. These standards refer to the obligation of the SAls to report and be held accountable for its performance and use of resources, and this includes by parliament."

\section{ISSAI 20 - Principles of Transparency and Accountability}

Under Principle 6 of ISSAI 20 about SAls reporting publicly on their performance and use of resources, the sub-principles state: SAls' financial statements are made public and are subject to external independent audit or parliamentary review; and SAls may use performance indicators to assess the 
value of audit work for parliament, citizens and other stakeholders. These indicate the role of parliament in holding the SAI accountable for its work.

Principle 7 states that SAls report publicly on the results of their audits and on their conclusions regarding overall government activities:

- SAls make public their conclusions and recommendations resulting from the audits unless they are considered confidential by special laws and regulations.

- SAls report on the follow-up measures taken with respect to their recommendations.

- SAls constituted as courts report on sanctions and penalties imposed on accounting officers or managers.

- SAls also report publicly on overall audit outcomes, e.g. the government's overall budget implementation, financial condition and operations, overall financial management progress and, if included in their Legal framework, on professional capacity.

- SAls maintain a strong relationship with relevant parliamentary committees to help them better understand the audit reports and conclusions and to take appropriate action.

In the accompanying presentation of Good practices (ISSAI 21), mention is made of SAls providing orientation and training in financial management for members of parliament, a guide on examining public spending for parliamentarians, and informal meetings with chairs and members of parliamentary committees to explain the role and mandate of the SAI and receive feedback on the needs of various committees.

\section{SAI Performance Measurement Framework}

In the context of ISSAI 12, the INTOSAI Working Group on the value and benefits of SAls developed the PMF. The framework has been tested in several INTOSAI regions, with a final version endorsed during the 2016 INCOSAl in Abu Dhabi. The PMF includes a dimension on communication with the legislature, the executive and the judiciary. Under this dimension, the Good practices the SAI should attempt to achieve are:

a) Consider questions raised during public debates in the parliament when formulating its overall audit plan, without need of a formal request being made.

b) Seek available opportunities, within the conventions and practices of the country, to engage with the parliament and members of relevant committees, and to present relevant audit reports and SAI results.

c) Contribute to the legislative process, proposing recommendations or amendments aiming at the improvement of the public management system.

d) When requested, provide the legislature with timely access to information related to the work of the SAI.

e) Where appropriate, seek feedback from members of the parliament and relevant committees on its performance.

f) Develop professional relationships with relevant legislative oversight committee to help them better understand the audit reports and conclusions and take appropriate action.

g) Raise awareness of the parliament on the SAl's role and mandate. 
h) Establish policies and procedures regarding its communication with the legislature.

Stapenhurst, Rick et al. (2014), Following the Money: Comparing Parliamentary Public Accounts Committees $^{29}$ presents some characteristics that may contribute to an ideal public accounts committee:

- The Committee is small; committees seem to work well with 5-11 members, none of whom should be government Ministers.

- Senior opposition figures are associated with the PAC's work, and probably chair the Committee.

- The Chair is a senior parliamentarian, fair-minded and respected by parliament.

- The Committee is appointed for the full term of the parliament.

- The Committee is adequately resourced, with an experienced clerk and competent researcher(s).

- There is clarity on the Committee's role and responsibilities.

- The Committee meets frequently and regularly.

- Hearings are open to the public; a full verbatim transcript and summary minutes are quickly available for public distribution.

- A steering committee plans the Committee's work in advance and prepares an agenda for each meeting to the full Committee.

- The typical witness is a senior public servant (the "accounting officer") accompanied by the officials that have a detailed understanding of the issues under examination.

- The Auditor's Report is automatically referred to the Committee and the Auditor meets with the Committee to go over the highlights of the report.

- In addition to issues raised by the Auditor, the Committee occasionally decides to investigate other matters.

- The Committee strives for some consensus in its reports.

- The Committee issues formal substantive reports to parliament at least annually.

- The Committee has established a procedure with the government for following up its recommendations and is informed about what, if any, action has been taken.

- In all its deliberations, the Committee uses the Auditor as an expert advisor.

- Parliaments hold an annual debate on the work of the Committee.

Buzaljko, Karolina et al. (2010), Public Financial Oversight; A Comparative Analysis of Parliamentary Committees Across Europe

Pages 56-60 of this research report on public financial oversight ${ }^{30}$ summarise conclusions that may partially be used as criteria for effective working relations from the parliament's perspective.

Stapenhurst, Rick et al. (2014), Following the Money: Comparing Parliamentary Public Accounts Committees, Pluto Press, London. 
1. The mandate of public finance committees (PFCs, a term used to cover the different types of committees usually dealing with SAI reports, like budget committees or public accounts committees) should be clearly defined and should have a wide scope.

2. In the composition of PFCs, special consideration should be given to members of the opposition.

3. Continuity of PFC work across parliamentary terms is essential to ensure that SAI reports are properly followed up.

4. Active participation of the members and chair is important.

5. Training for members of PFCs at the beginning of their term and during their mandate is useful.

6. Adequate staffing and resources of PFCs should be ensured.

7. PFCs should meet frequently enough to ensure sufficient consideration of SAI reports.

8. Clear follow-up mechanisms should be established by the PFC, complementary to follow-up mechanisms that the SAI may have.

9. PFCs should be as transparent as possible, meeting and reporting in public, resulting in maximal pressure on the executive to improve management and control.

10. PFCs should report annually on the state of public financial oversight, and should assess their own performance to allow for improvements in their functioning. 
ANNEX 2. TOOLKIT FOR STRENGTHENING WORKING RELATIONSHIPS BETWEEN SAIS AND PARLIAMENTS

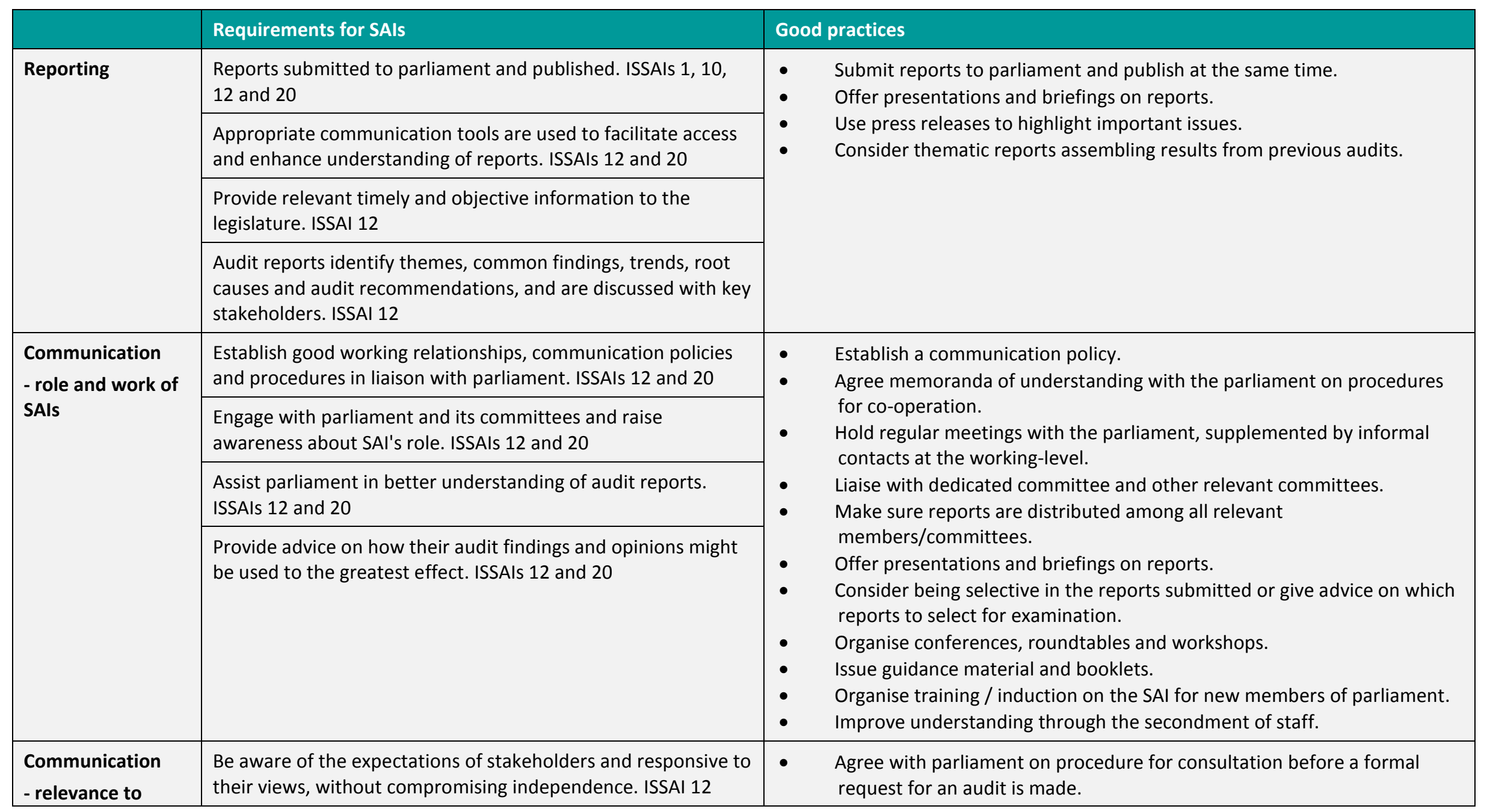




\begin{tabular}{|c|c|c|}
\hline & Requirements for SAls & Good practices \\
\hline \multirow[t]{2}{*}{ stakeholders } & $\begin{array}{l}\text { Ensure that stakeholders' expectations and views are factored } \\
\text { into organisational and audit planning. ISSAI } 12\end{array}$ & \multirow{2}{*}{$\begin{array}{l}\text { - } \quad \text { Limit the number of audits on request carried out at the same time or } \\
\text { during the year. } \\
\text { - } \quad \text { Inform parliament about the Work programme (if this is legally possible). } \\
\text { Organise opportunities for parliament to regularly provide input (through } \\
\text { meetings, interviews). } \\
\text { Follow relevant discussions in parliament for identification of potential } \\
\text { audits. }\end{array}$} \\
\hline & $\begin{array}{l}\text { Assess whether stakeholders believe that the SAI is effective } \\
\text { and contributes to improvements in the public sector. ISSAI } 12\end{array}$ & \\
\hline \multirow[t]{3}{*}{$\begin{array}{l}\text { Communication - } \\
\text { other }\end{array}$} & $\begin{array}{l}\text { Communication contributes to stakeholders' awareness of the } \\
\text { need for transparency and accountability in the public sector. } \\
\text { ISSAI } 12\end{array}$ & \multirow{3}{*}{$\begin{array}{l}\text { - Annual reports on activities and the implementation of the Work } \\
\text { programme are prepared and published. } \\
\text { External peer reviews are conducted on a regular basis with public } \\
\text { reporting. } \\
\text { - Consider thematic reports assembling results from previous audits. }\end{array}$} \\
\hline & $\begin{array}{l}\text { Periodic assessment of whether the SAI is communicating } \\
\text { effectively. ISSAI } 12\end{array}$ & \\
\hline & $\begin{array}{l}\text { Contribute to the debate on improvements in the public sector. } \\
\text { ISSAI } 12\end{array}$ & \\
\hline \multirow[t]{2}{*}{ Follow-up } & Submit follow-up reports to parliament. ISSAIs 10,12 and 20 & \multirow[b]{2}{*}{ 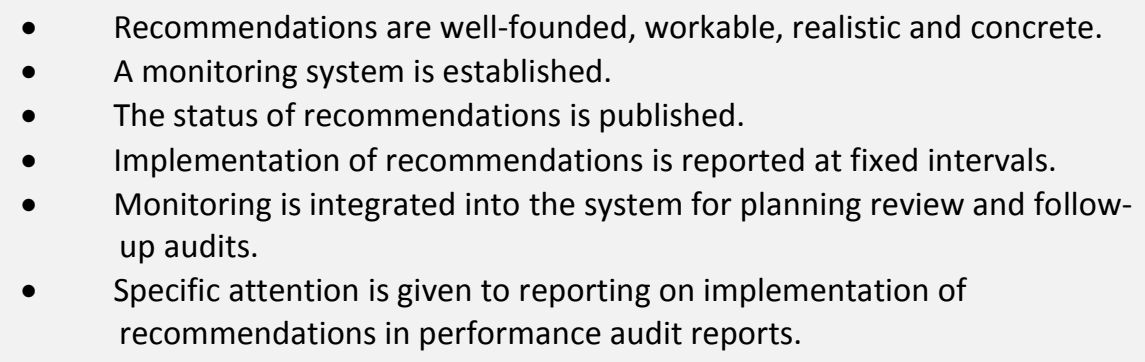 } \\
\hline & $\begin{array}{l}\text { Monitor and follow up on recommendations from SAI and } \\
\text { parliament. ISSAls } 10 \text { and } 20 \text {, Principles of Public } \\
\text { Administration - Principle } 16\end{array}$ & \\
\hline \multirow{2}{*}{$\begin{array}{l}\text { Reporting } \\
\text { Performance }\end{array}$} & Submit an annual activity report to parliament. ISSAI 10 & \multirow{2}{*}{$\begin{array}{l}\text { - Audited annual reports on accounts and use of resources are prepared } \\
\text { and published. } \\
\text { Annual reports on activities and the implementation of the Work } \\
\text { programme are prepared and published. } \\
\text { External peer reviews are conducted on a regular basis with public } \\
\text { reporting. } \\
\text { Estimates of savings are made for the public sector. }\end{array}$} \\
\hline & $\begin{array}{l}\text { SAls should be subject to external scrutiny and report the } \\
\text { results to stakeholders. ISSAIs } 12 \text { and } 20\end{array}$ & \\
\hline
\end{tabular}




\begin{tabular}{|c|c|c|}
\hline & Expectations for Parliaments & Good practices \\
\hline Accountability & $\begin{array}{l}\text { Parliament holds government to account. The Principles of } \\
\text { Public Administration and PEFA }\end{array}$ & $\begin{array}{l}\text { - } \quad \text { Standard procedures for handling audit reports are developed. } \\
\text { - } \quad \text { Hearings are held with the auditee. } \\
\text { - } \quad \text { Deadlion plan from the govere set for action planent or auditee is required. } \\
\text { Sanctions from the SAI or parliament (political, financial and } \\
\text { disciplinary) are considered in cases of serious non-compliance with } \\
\text { recommendations. } \\
\text { - Implementation reports from auditees or government are required. }\end{array}$ \\
\hline \multirow[t]{3}{*}{$\begin{array}{l}\text { Handling of SAI } \\
\text { reports }\end{array}$} & $\begin{array}{l}\text { Parliament has a formal mechanism for considering SAI } \\
\text { reports. The Principles of Public Administration - Principle } 16 \\
\text { and PEFA }\end{array}$ & \multirow{3}{*}{$\begin{array}{l}\text { - Committee responsibilities for SAI reports are adequately organised } \\
\text { of. } \\
\text { - A specialised audit committee or audit subcommittee has been } \\
\text { established. } \\
\text { - Sectoral committees are involved in dealing with performance audit } \\
\text { reports. } \\
\text { - A formal discharge procedure is part of the budget cycle in the } \\
\text { context of budgetary oversight. } \\
\text { - } \quad \text { A rapporteur is assigned for specific SAI report. } \\
\text { - } \quad \text { A scordinate agendas and reporting timetables with the parliament. } \\
\text { - } \quad \text { make timely conclusions possible. } \\
\text { Sufficient staff and analytical resources are available in parliament. }\end{array}$} \\
\hline & $\begin{array}{l}\text { Parliament ensures timely examination of audit reports and } \\
\text { issues conclusions or recommendations. PEFA }\end{array}$ & \\
\hline & $\begin{array}{l}\text { Parliament follows up on their implementation by } \\
\text { government. PEFA }\end{array}$ & \\
\hline
\end{tabular}




\section{ANNEX 3. QUESTIONNAIRE}

\section{1) Legal framework:}

a) Could you please describe the Legal framework in respect to the SAl's obligations to parliament (e.g. communication on the SAl's work plan, the SAl's reporting obligations, and the need to consider audits on request by Parliament)? Please consider what is defined in the Constitution and the State Audit Law and, if relevant, the Budget System Law or similar.

\section{2) SAl reporting practices:}

a) Please describe what type of reports that the SAI sends to parliament, for example financial audits, compliance audits, performance audits, opinions, annual/quarterly (activity) reports (including reports on the work of the SAI itself, on how it has carried out its mandate). Please also provide information on:

- $\quad$ whether the SAI reports separately on individual audits, or if the results from several audits are combined in one report;

- to whom are reports addressed (Speaker of Parliament and/or Chair of dedicated ${ }^{31}$ committee) and whether they are copied (or not) to other relevant committees;

- $\quad$ whether there are any timescales or deadlines for the submission of reports to Parliament.

b) Does the SAI have any specific procedures in respect of sending its reports to Parliament; and does it undertake any other activities in respect of reports such as briefings or presentations to Parliament/parliamentary committee?

c) Please complete the following table to provide information on the number and type of reports submitted to Parliament by the SAI during 2015. If the classification of financial, compliance and performance is not appropriate to how your institution reports its audit work to parliament, please still provide the number of audit reports submitted and details of how the SAI reports its audit work.

31 Dedicated committee: a parliamentary committee mandated on the basis of law or internal parliamentary procedures to handle SAI reports. 


\begin{tabular}{|c|c|c|c|c|c|c|c|}
\hline & $\begin{array}{l}\text { Financial } \\
\text { audit } \\
\text { reports }\end{array}$ & $\begin{array}{l}\text { Compliance } \\
\text { audit reports }\end{array}$ & $\begin{array}{l}\text { Performance } \\
\text { audit reports }\end{array}$ & $\begin{array}{l}\text { Other reports } \\
\text { or documents }\end{array}$ & $\begin{array}{l}\text { Annual } \\
\text { activity } \\
\text { reports }\end{array}$ & $\begin{array}{l}\text { Reports at } \\
\text { request of } \\
\text { Parliament }\end{array}$ & Remarks \\
\hline Number submitted & & & & & & & \\
\hline $\begin{array}{l}\text { Number discussed } \\
\text { by Parliament }\end{array}$ & & & & & & & \\
\hline $\begin{array}{l}\text { Submitted to } \\
\text { Speaker }\end{array}$ & $y / n$ & $y / n$ & $y / n$ & $y / n$ & $y / n$ & $y / n$ & \\
\hline $\begin{array}{c}\text { Submitted to Chair } \\
\text { of dedicated } \\
\text { committee }\end{array}$ & $y / n$ & $y / n$ & $y / n$ & $y / n$ & $y / n$ & $y / n$ & \\
\hline $\begin{array}{c}\text { Copied to other } \\
\text { relevant } \\
\text { committees }\end{array}$ & $y / n$ & $y / n$ & $y / n$ & $y / n$ & $y / n$ & $y / n$ & \\
\hline $\begin{array}{l}\text { Briefings organized } \\
\text { for parliamentary } \\
\text { committee }\end{array}$ & $y / n$ & $y / n$ & $y / n$ & $y / n$ & $y / n$ & $y / n$ & \\
\hline $\begin{array}{l}\text { Summaries } \\
\text { submitted to } \\
\text { parliament }\end{array}$ & $y / n$ & $y / n$ & $y / n$ & $y / n$ & $y / n$ & $y / n$ & \\
\hline
\end{tabular}

\section{3) Parliamentary procedures for SAI reports:}

a) Could you please describe the parliament's procedures for handling the SAls report? In answering please provide details on whether:

- $\quad$ there are fixed procedures for handling SAI reports laid down in parliaments rules of procedure or equivalent;

- $\quad$ there is a dedicated committee that exists for handling SAI reports, and whether it is chaired by a member of the opposition or the government party/parties, and whether that is based on tradition, procedure or political negotiations.

- the committee appoints a rapporteur, for instance for a specific audit report;

- there are hearings held to which the auditee or other appropriate persons are invited to provide clarification or further information;

- the committee can use independent external experts in examining reports if required or request additional information or clarification in writing from appropriate persons;

- the debate on SAI reports is held in committee(s) and/or plenary;

- other committees, apart from any dedicated committee, also consider the reports of the SAl;

- a parliamentary "product" is produced as an outcome of a debate on a SAI report, for example a resolution or report, and whether these "products" are published; 
- the parliament has a fixed procedure for discharge, is it being followed in practice and whether the SAI and/or its reports play a role in this procedure.

b) Please provide details about the number and level of parliamentary staff supporting the committee(s) dealing with SAI reports. Please also provide details about their role, for example do they:

- $\quad$ provide written research, analysis or briefings in preparation for debates on SAI reports;

- develop questions for the committee(s) to ask at hearings;

- draft reports or other outputs of the committee(s).

c) Please provide details of the involvement of the SAI in parliaments considerations of its reports. For example does the:

- SAI have any involvement in the committee or parliaments preparation for hearings;

- SAI attend parliamentary meetings when SAI reports are debated, what is the level of SAI representation and what type or level of contribution to the meetings can they make.

4) SAI reports:

- Does the SAl focus on generic/systemic problems and recommendations in its communications to Parliament?

- Is the set-up and functioning of the internal control systems a subject that is highlighted in SAI reports?

- Do all audit reports contain clear conclusions and audit opinions?

5) Follow up on SAI reports:

a) Could you please describe how the SAI monitors and follows up on report conclusions and recommendations. In considering please provide details about whether:

- the SAI keeps track of conclusions and recommendations accepted by auditees, and the kinds of tools that are used to keep track of conclusions and recommendations;

- the Parliament pays attention to the implementation of SAI recommendations in audit reports and the mechanisms used by them to do so;

- the SAI reports specifically on the implementation/non-implementation of recommendations, including those in respect of the set up and functioning of internal control systems, and if so, does this stimulate parliamentary follow up;

- the government is required to report on the implementation of SAI recommendations. Are SAI reports regularly used as input for the annual debate on draft budgets?

6) Audits on Parliament's request:

a) If a legal provision exists that enables parliament to request audits could you please describe how it is used in practice and how often? If no legal provision exists, does parliament nevertheless ask the SAI to carry out audits on specific subjects, or to provide advice, and if so, please describe how the SAl responds? 


\section{7) Work programme:}

a) Does the SAI consult Parliament (Parliamentary Committees, Speaker of Parliament, other parliamentary bodies, etc.) on its (multi-) annual Work programme of audits? If so, please describe how this consultation is undertaken, whether Parliament comes up with suggestions, and whether the SAl takes these into serious consideration.

8) Level and frequency of contacts:

a) Please describe the level and frequency of formal and informal contact between the SAI and Parliament. For example please describe whether:

- there is regular contact (including informal) between the head of the SAl and the Chair of competent committee in Parliament, and how often this occurs (e.g. monthly, quarterly etc.);

- $\quad$ there are contacts at a day to day working level; and

- there are any SAI-staff or unit specifically tasked with Parliamentary relations.

9) Good practice:

a) Are there any specific examples that you would like to highlight as Good practice in how the SAl manages its relationships with the Parliament to increase the impact of its work and reports?

\section{0) Perspective:}

a) What are weaker points in the current relationship, and what is envisaged will be done in order to address these points in the foreseeable future? How is it foreseen that the SAI and Parliament will work together in this respect?

11) Are there any other relevant features of the current relations between the SAI and Parliament that you would like to highlight, and how have they evolved over the past five years? 


\section{SAl Contributions}

Country contributions were provided by the Supreme Audit Institutions of EU member countries and the Network in reply to a survey conducted in early 2016. While SIGMA has edited these contributions, as a

matter of principle it has not materially changed the text; the SAls remain responsible for the content of their contribution. 


\section{ALBANIA}

The Supreme State Audit

\section{1) Legal framework}

According Article 164 of the Constitution of Albania, the Supreme Audit Institution of Albania (ALSAI) presents to Albania's Parliament the report on the implementation of the State budget for the previous year, an opinion on the report of the Council of Ministers on last year's State budget expenses (before Parliament's approval of the coming year State budget), information on the results of audits whenever requested by the Parliament, and an annual report on its activities.

The SAI obligation to produce the above reports to Parliament is also included in the SAI Law.

\section{2) SAI reporting practices}

ALSAI sends to Parliament the report on the implementation of the State Budget for the previous year, together with an opinion on the report of the Council of Ministers on last year's State budget expenses before Parliament's approval of the coming year State budget. The report includes the results of several financial audits, compliance audits, performance audits and IT audits performed by ALSAI during the year in question.

ALSAI sends also to Parliament an annual report (SAI performance report) on its audits and other activities.

Both above reports show the results of several audits combined in one report.

Both reports are addressed to the Chair of the dedicated Parliamentary Committee which is the Committee on Economy and Finances. They are copied and distributed to each member of the Committee, and later to each member of Parliament, before their discussion in plenary session.

ALSAI presents the report on the implementation of the State Budget at the beginning of October, and its Performance Report at the end of April each year.

Each report is prefaced with a briefing underlining the most important messages from the report. 
Number and type of reports

\begin{tabular}{|c|c|c|c|c|c|c|c|}
\hline & $\begin{array}{l}\text { Financial } \\
\text { audit } \\
\text { reports }\end{array}$ & $\begin{array}{l}\text { Compliance } \\
\text { audit reports }\end{array}$ & $\begin{array}{l}\text { Performance } \\
\text { audit reports }\end{array}$ & $\begin{array}{l}\text { Other reports or } \\
\text { documents }\end{array}$ & $\begin{array}{c}\text { Annual activity } \\
\text { reports }\end{array}$ & $\begin{array}{l}\text { Reports at } \\
\text { request of } \\
\text { Parliament }\end{array}$ & Remarks \\
\hline $\begin{array}{c}\text { Number } \\
\text { submitted }\end{array}$ & \begin{tabular}{|c|} 
Not \\
available \\
separately, \\
see the SAI \\
performance \\
report \\
\end{tabular} & 1 & $\begin{array}{l}\text { Not available } \\
\text { separately, see } \\
\text { the SAI } \\
\text { performance } \\
\text { report }\end{array}$ & \begin{tabular}{|c|} 
Report on the \\
implementation of \\
the State budget \\
for the previous \\
year
\end{tabular} & $\begin{array}{l}\text { SAI } \\
\text { performance } \\
\text { report that } \\
\text { includes the } \\
\text { results of all } \\
\text { financial, } \\
\text { compliance, } \\
\text { performance } \\
\text { and IT audits } \\
\text { performed } \\
\text { during } 2015\end{array}$ & Not applicable & \\
\hline $\begin{array}{c}\text { Number } \\
\text { discussed by } \\
\text { Parliament }\end{array}$ & & & & \begin{tabular}{|} 
The ALSAI report \\
on implementation \\
of State budget for \\
2014 was \\
discussed by the \\
Parliament in the \\
plenary session \\
during which the \\
Parliament \\
approved the State \\
Budget for 2016
\end{tabular} & \begin{tabular}{|} 
SAI \\
Performance \\
Report was \\
discussed by \\
the Committee \\
on Economy \\
and Finances
\end{tabular} & & \\
\hline $\begin{array}{l}\text { Submitted to } \\
\text { Speaker }\end{array}$ & $\begin{array}{c}\text { Not } \\
\text { available }\end{array}$ & 1 & Not available & Yes & Yes & Not applicable & \\
\hline $\begin{array}{c}\text { Submitted to } \\
\text { Chair of dedicated } \\
\text { committee }\end{array}$ & $\begin{array}{c}\text { Not } \\
\text { available }\end{array}$ & 1 & Not available & Yes & Yes & Not applicable & \\
\hline $\begin{array}{l}\text { Copied to other } \\
\text { relevant } \\
\text { committees }\end{array}$ & $\begin{array}{c}\text { Not } \\
\text { available }\end{array}$ & Not available & Not available & Yes & Yes & not applicable & \\
\hline $\begin{array}{l}\text { Briefings } \\
\text { organised for } \\
\text { Parliamentary } \\
\text { Committee }\end{array}$ & $\begin{array}{c}\text { Not } \\
\text { available }\end{array}$ & Not available & Not available & Not available & Not available & Not applicable & \\
\hline $\begin{array}{l}\text { Summaries } \\
\text { submitted to } \\
\text { Parliament }\end{array}$ & $\begin{array}{c}\text { Not } \\
\text { available }\end{array}$ & Not available & Not available & Not available & Not available & Yes & \\
\hline
\end{tabular}




\section{3) Parliamentary procedures for SAI reports}

There is a dedicated committee that handles SAI reports. It is called the Committee on Economy and Finances. It is chaired by a member of the Government parties, agreed by negotiation.

The debate on SAI reports is held in the Committee on Economy and Finances, and sometimes in plenary sessions. Members of Parliament refer to the SAI report on the State Budget Implementation of the previous year in the plenary session in which the State Budget for the coming year is approved. Members of Parliament refer to SAl's Performance Report when there is a Parliamentary Resolution on SAI discussed and approved in plenary session.

The dedicated committee can appoint a rapporteur for a specific audit report, but until now this has not been the case in practice.

The dedicated committee can use independent external experts in examining reports if required, or request additional information or clarification in writing, but until now this has not been the case in practice.

The dedicated committee can call for hearings in which the auditee or other appropriate persons are invited to provide clarification or further information, but until now this has not been the case in practice.

Other committees, apart from the dedicated committee (Committee on Economy and Finances), can also consider the reports of the SAI, but until now this has not been the case in practice.

A parliamentary "product", a resolution on the SAl's performance with guidelines on the SAl's future operation is produced from time to time. The last Resolution was on 26 June 2014 entitled "Resolution for the evaluation of the activity of ALSAI for the year 2013" and was published in the Official Journal No. 101 dated 2 July 2014.

\section{Staffing}

The Parliament does not have extended support staff for the committees. There is one secretary of the Committee on Economy and Finances, who prepares the minutes each time the Committee meets to discuss SAI reports, and these minutes are published on Parliament's website.

\section{SAI involvement in consideration of reports by Parliament}

On request of the dedicated committee (Committee on Economy and Finances) or other committees, ALSAI can prepare written documents/clarifications or meet committee representatives to support them in preparation for hearings, but until now this has not been the case in practice.

ALSAI attends parliamentary meetings when SAI reports are debated at committee or plenary level. Usually the SAI is represented by the Head of SAI (the Chair of ALSAI) accompanied by SAI General Secretary and Legal Department Director. They answer questions from committee members or Members of Parliament in plenary meetings and provide clarifications when asked.

\section{4) SAI reports}

ALSAI in its reports to Parliament focuses on generic/systemic problems and recommendations. It produces this focus twice, in the briefings serving as introduction to both the report on the 
implementation of the State Budget and the SAl's Annual Performance Report, and in a more detailed form in both reports.

The set up and functioning of internal control systems is a subject that is highlighted in both ALSAI reports, but especially in the report on the implementation of the State Budget. The recommendations to improve the system and the operation of internal control, as well as the quality and competence of internal auditors are among the main recommendations of SAI reports.

All audit reports contain clear conclusions and audit opinions.

\section{5) Follow-up on SAI reports}

ALSAI keeps track of findings, conclusions and recommendations accepted by auditees and the kinds of tools that are used by the auditee to keep track of progress. In each new audit, the first thing the audit team does is to evaluate the level of implementation of SAI recommendations contained in the last audit report.

The Parliament pays attention to the implementation of SAI recommendations in audit reports, but until now efficient parliamentary follow-up of these recommendations has not been in place, as highlighted by the last EU Progress Reports on Albania.

ALSAI reports specifically and frequently on the implementation/non-implementation status of its recommendations, including those in respect of the set up and functioning of internal control systems. Until now, Parliament's stimulation to follow them up has not been efficient.

Parliament has not required the Government to report on the implementation of SAI recommendations. SAI reports are regularly used as input by Members of Parliament for the annual debate on draft budgets.

\section{6) Audits on Parliament's request}

There is no legal provision to enable Parliament to request audits, but ALSAI does consider as high priority any request or suggestion coming from Members of Parliament for potential audit themes in the future, or to additional information in respect to performed audits. Usually these requests and suggestions are produced during the dedicated committee meetings to discuss SAI reports, but they can come also from informal meetings of Members of Parliament with the Head of SAl, or with other senior staff, or from declarations and statements of Members of Parliament in the media.

\section{7) Work programme}

ALSAI does consult Parliament on its (multi-) annual Work programme of audits. It does so by inviting members of the dedicated committee (Committee on Economy and Finances) to participate in its annual performance analysis, in its activities to promote audit work and in its, annual Scientific Conference.

ALSAI distributes its publications to members of the dedicated committee (Committee on Economy and Finances) in electronic and hard copy. Over the last 4 years 2012-2015, ALSAI has published 50 books.

Any time Members of Parliament come up with suggestions, ALSAI does consider them very seriously. 


\section{8) Level and frequency of contacts}

There is regular contact (including informal) between the Head of the SAI and the Chair of competent committee in Parliament (Committee on Economy and Finances). Usually this occurs monthly.

There are no day to day contacts, as the members of the dedicated committee are very busy.

There is no SAI staff or unit specifically tasked with Parliamentary relations, but the Head of SAI usually maintains and develops these relations. ALSAI is ready to dedicate staff and introduce a special unit tasked with Parliamentary relations, but this depends on Parliamentary understanding of the importance of increasing SAI-Parliament relations. ALSAI is working to increase Parliamentary understanding of its work.

\section{9) Good practice}

The long process of Parliament's endorsement of the new ALSAI law in 2014, in full compliance with INTOSAI standards (as declared by the DG-Budget and the EU delegation in Tirana), is a good example of SAl's intensive attempts to increase its independence and the impact of its work and reports.

\section{0) Perspective}

A weak point is that SAl's work and reports are not sufficiently known by the other committees and by Members of Parliament in general.

Consultation and information sharing meetings with SAI and other committees are seen by ALSAI as an efficient tool to increase the level of knowledge and understanding of Parliament about SAI.

11) Are there any other relevant features of the current relations between the SAI and Parliament that you would like to highlight, and how have they evolved over the past five years?

ALSAI generally has a good level of implementation of its recommendations, except for the recommendation to remove from post and civil service those high ranked public officials caught by SAl in abuse with State interests. This implementation level is very low. ALSAI would like more Parliamentary involvement to push the Government to implement such recommendations, as they directly fight the anti-culture of impunity in the country. 


\section{AUSTRIA}

Court of Audit

\section{1) Legal framework}

The Austrian Court of Audit (ACA) scrutinises on federal, laender and municipal level whether public resources are used economically, efficiently and effectively. Its core tasks are auditing and consulting services. The activities, functions, organisation and position of the ACA are governed by Chapter VI of the Federal Constitutional Law (http://www.rechnungshof.gv.at/en/austrian-court-of-audit/legalprovisions/the-title-five-of-the-federal-constitution-audit-of-financial-operations.html). More information on this is contained in the Laender Laws (http://www.rechnungshof.gv.at/en/aca/legalprovisions/laender-constitutions.html) and the Austrian Court of Audit Act (http://www.rechnungshof.gv.at/en/aca/legal-provisions/federal-act-on-the-austrian-court-ofaudit.html\#c659).

Under Article 126d of the Austrian Federal Constitutional Law, the ACA shall report to the National Council on its activities during the preceding year, at the latest by 31 December of each year (Activity Report). The same obligations for laender and municipal level are in Article 127 paragraph 6 and Article 127a paragraph 7 of the Austrian Federal Constitutional Law. The reports issued by the ACA are published on the ACA's website after submission to the National Council, Land Parliament and Municipal Council.

The ACA submits (based on Article 121 paragraph 2 of the Austrian Federal Constitutional Law) to the National Council a Report on the Annual Federal Financial Statements, which presents the federal revenue and expenditure during the previous fiscal year and allows an assessment of the actual management of the budget.

The first deliberation on the ACA's reports takes place in the Court of Audit Committee of the National Council. After the Court of Audit Committee considers the ACA's reports they go to the plenary session of the National Council. Similar provisions exist on laender and municipal level (for Land Parliament and Municipal Council). The rules of procedure of the National Council and the Laender Parliaments govern the strategically important participation of the ACA in committee meetings and plenary sessions. According to Article 123a of the Austrian Federal Constitutional Law, the President of the ACA has the right to participate in debates of the National Council and its committees (and subcommittees) on the reports issued by the ACA. This covers the Federal Financial Statements, motions for particular acts of audit to be performed by the ACA, and on the sections of the Federal Finance Bill about the ACA's work. Under the detailed provisions of the National Council Rules of Procedure Act, the President of the ACA has the right to be heard in the debates on these subjects.

The selection of audit topics by the ACA is completely independent. According to Art 126b paragraph 4, the ACA shall, by decision of the National Council or at the request of the National Council members, carry out particular acts of audit of the management of funds which fall into its sphere of competence. The more detailed regulation is laid down by the National Council Rules of Procedure Act. The ACA shall likewise carry out such audits at the substantiated request of the Federal Government or a Federal Minister, and report the audit findings to the applicant authority. Similar provisions exist at laender and municipality level. 


\section{2) SAI reporting practices}

The ACA presents performance, compliance and financial audit reports at any time, and its activity report at the end of the year. Several audits are covered in one report compilation. In addition to these reports, the ACA submits the report on the average incomes and retirement pensions paid by federal government enterprises and agencies, as well as the report on the average income of the total population (Income report). That the ACA also submits also an annual report and further reports on topics of major concern (e.g. most recently the position paper on a more efficient school administration).

The reports are distributed to Parliament and all relevant authorities as required. In addition to the Members of Parliament (MEPs) of the Court of Audit Committee, the ACA informs all MEPs of other Parliament committees depending on the topic of the report (e.g. MEPs of the Transport Committee for transport issues). After distribution to Parliament the reports are published on the website of the ACA.

The ACA submits the annual Federal financial accounts to the National Council by 30 June, and its activity report at the end of the year.

\section{Procedures for sending reports to Parliament}

Under Article 126d paragraph 1 of the Federal Constitutional Law, the ACA reports to the National Council on its audit findings. Several hard copies of the report are then submitted to the National Council. The reports are discussed in the Court of Audit Committee, which was set up for this purpose. MEPs decide which reports are discussed when. After the MEPs have made their comments, the President of the ACA explains the audit findings of the ACA. The report is then discussed at the plenary session of the National Council, at which the President of the ACA can take the floor, after comments by the MEPs.

The ACA holds briefings for the MEPs before Committee meetings if required.

\section{Number and type of reports}

The ACA audits the financial management of the public sector based on the principles of economy, efficiency and effectiveness. The audits of the ACA are inclusive and make no distinction between financial, compliance und performance audits.

In 2015 the ACA presented 18 report compilations with 71 reports, the Report on the Annual Federal Financial Accounts, and its Annual Report to the National Council. In that year, 84 report compilations with 122 reports were presented to laender and eight report compilations with eight reports to municipalities.

In 2015, the National Council dealt with the reports of the ACA as part of 10 meetings of the Court of Audit Committee, three meetings of the Budget Committee and five plenary sessions (these sessions may also include reports which have not been dealt with in previous years).

\section{3) Parliamentary procedures for SAI reports}

Under Article 126d paragraph 2 of the Federal Constitutional Law, a standing committee, the Court of Audit Committee, was set up by the National Council to discuss the reports of the ACA. Formal provisions about the Committees (i.e. formation, procedural rules etc.) are laid down in sections 29 to 45 of the National Council Rules of Procedure Act. The President of the National Council sets up the meeting, and 
the committee elects a chair, secretary, and the vice-chairs found to be necessary (section 34 paragraph 1 and 2 of the National Council Rules of Procedure Act).

The elected chair of the Court of Audit Committee is (regularly) a MEP of the opposition. At the beginning of each meeting the committee choses a rapporteur for each single report. After final debate in the Committee the Committee recommends to the National Council (plenary session) to take notice of the discussed audit report.

The Committees are free to invite experts to attend committee meetings if it is deemed necessary. For instance, the Austrian Member at the ECA has been invited twice to the Court of Audit Committee meetings regarding EU topics in the last 2 years.

\section{Staffing}

There are six political parties represented in the National Council as well as in the Court of Audit Committee. The Members of the National Council who are members of the Court of Audit Committee are supported by one staff member per political party, who are in charge of dealing with the topics discussed in the Court of Audit Committee. The preparation of committee meetings is up to the MEPs and their staff.

\section{SAl involvement in consideration of reports by Parliament}

The President of the ACA can attend and speak at the National Council's plenary sessions and its committees and sub-committees during discussion on ACA reports and the report of the Federal Financial Accounts. This also applies to discussions about instructions to investigate issues and for discussions of the ACA budget.

Under section 49 paragraph 1, the ACA reports to the National Council about its activities during the preceding year and about special audit activities under section 99 by 31 December of each year. In addition, the ACA may report to the National Council at any time about specific findings.

The President shall refer reports of the ACA for preliminary deliberation to the standing committee for this purpose (Court of Audit Committee) at the sitting following their distribution. The Federal Financial Statements are referred to the committee under section 32a.

The committee begins to discuss the ACA reports within six weeks. The Court of Audit Committee may decide what respondents are heard in a public meeting, subject to the provisions of section $28 \mathrm{~b}$ paragraph 2. Sound and visual recordings are not permitted. During the debate no contribution can be longer than 10 minutes.

The President of the ACA always takes part in these committee meetings. He is accompanied by the responsible Director General, the audit team leader and, if necessary, one (or more) member(s) of the audit team.

\section{4) SAI reports}

The ACA chooses a theme to prioritise in its audit programme for the coming year. Internal control systems are a regular subject for audits. In 2014, the audit programme of the ACA focused on internal control systems, and the ACA conducted 30 audits in this area. The results of the ACA's audits on internal 
control systems are included in the ACA's guideline on internal control systems, which strengthens the consulting function of the ACA.

All of the reports published by the ACA contain clear conclusions and audit opinions.

\section{5) Follow-up on SAI reports}

The ACA has developed a new system of evaluating the effectiveness. At the first stage, the recommendations in the previous year's reports are surveyed, i.e. organisations that were audited are asked about the progress implementing recommendations (desk-based, classification: implemented / assured / outstanding). The results of the follow-up enquiry are published in the annual Activity Report.

Based on this follow-up enquiry follow-up audits are carried out as the second stage of effectiveness evaluation. Follow-up audits are small, focused on the implementation of selected audit recommendations. The ACA checks at the audited organisation what progress has actually been made (on-the-spot audit). The ACA publishes a separate audit report about the findings of the follow-up audits. These reports are then again subject to the annual enquiry procedure.

This evaluation of effectiveness is an important element to the sustainability of auditing because it increases the value of the auditing activity and heightens the effectiveness of recommendations.

\section{6) Audits on Parliament's request}

According to Sections 1 paragraph 4 and 15 paragraph 4 of the Federal Act on the Austrian Court of Audit, the ACA can be entrusted with special audits by the National Council or a provincial diet.

Section 99 paragraph 1 of the Rules of Procedure of the National Council specifies that "1) The National Council may ... decide to ask the Court of Audit to carry out special audits of the management of public funds."

According to section 99 paragraph 2, such audits can also be called for by a qualified minority of 20 Members of the National Council.

Section 99 paragraph 3 adds that no further motions may be tabled as long as three audits of the management of public funds under paragraph (2) are pending.

In 2015 the ACA carried out three requested audits (out of 100 audits in total).

\section{7) Work programme}

The ACA prepares its audit programme in an independent manner. The Parliament is entitled to ask for special audits (see above).

\section{8) Level and frequency of contacts}

The ACA provides comprehensive information to questions from Members of the National Council and their employees about its published audits. There are active talks with the Members of the National Council and their employees, by which the ACA regularly updates its knowledge on developments and moods in the National Council. The goal is to maintain constant contacts with the Members of the National Council. 
At the ACA the department for communication and relations with Parliament is responsible for these regular contacts.

Formal contacts at the Court of Audit Committee meetings take place once a month (approximately 10 meetings per year).

\section{9) Good practice}

The National Council bases its controls of financial accounts and financial management on the audits of the ACA. It therefore holds many meetings in this regard; as explained above, there were 10 meetings in the Court of Audit Committee in 2015, which involved intensive discussions of the ACA's audit results. 


\section{BELGIUM}

Court of Audit

\section{1) Legal framework}

Established by Article 180 of the Constitution, the Belgian Court of Audit is a collateral body of Parliament. It carries out external scrutiny of the budgetary, accounting and financial operations of the Federal State, the Communities, the Regions, the public service institutions depending upon them, and the provinces.

The Court's powers are set out in the law of 29 October 1846, which has been amended several times, and in the law of 16 May 2003. The law grants a large independence to the Court and a real autonomy to perform its work.

The rules of procedure, were passed by the House of Representatives on 5 February 1998 and published in the Belgian Official Journal on 4 September 1998.

Article 5, paragraph 1, sub-paragraph 4 of the Act of 29 October 1846 organising the Court of Audit stipulates: "The House of Representatives may entrust the Court with audits on legality and regularity of some expenditure programmes as well as with financial audits in the departments and bodies subject to the Court's jurisdiction."

The last sub-paragraph of article 5, paragraph 1, of the Act of 29 October 1846 empowers the House of Representatives to entrust the Court of Audit with management audits in the departments and bodies subject to the Court's jurisdiction.

This legal provision had been recently applied.

\section{2) SAI reporting practices}

\section{Legal Obligations for SAI Reporting}

Reference is for instance made to article 180 of the Belgian Constitution, see https://www.dekamer.be/kvvcr/pdf sections/publications/constitution/GrondwetUK.pdf.

See also the Federal Act of 22 May 2003 (only in French) Loi du 22 mai 2003 portant organisation du budget et de la comptabilité de l'État fédéral:

Art. 54 . Le cas échéant, la Cour des comptes communique à la Chambre des représentants ses remarques sur les documents visés aux articles 45, 50, 51, 52 en 53.

Art. 75.Avant le [31 octobre] de l'année qui suit l'année budgétaire, la Cour des comptes transmet le compte général de l'administration générale à la Chambre des représentants avec ses observations, http://www.begroting.be/FR/law/loi\%20du\%2022\%20mai\%202003.htm.

\section{Objectives of the communication policy}

The communication policy reflects the values of the Court of Audit and the communication principles developed in its mission statement. 
The policy aims to disseminate correct, objective, complete, current, clear and useful information about the audits carried out by the Court of Audit. This information is delivered in paper and electronic reports. The Court of Audit directly provides the Parliamentary assemblies with useful and reliable information following on from its work. The findings, opinions and recommendations formulated in the reports enable this privileged recipient to carry out its legislative and budgetary function, as well as to control the executive power. Thanks to a broad distribution of clearly worded reports, the Court of Audit makes a large contribution to improving public management.

The Court of Audit's communication policy statement sets out:

- the principles underlying the Court's communication policy;

- the public character of its reports;

- the products that are being generated and the practical implementation of this policy.

\section{Principles of the communication policy}

- The communication policy aims to ensure a clear and univocal presentation of the findings, conclusions and recommendations made by the Court of Audit following its investigations.

- The discussion with the administration and the competent minister is recorded in the Court of Audit's publications to provide quality information.

- The Court of Audit sends and, if necessary, presents its reports to the Parliamentary assemblies where they are debated.

- Following the international standards on external audit and more specifically with the principle of a review procedure, the Court of Audit only provides information from the published reports. Its work at a later stage clarifies the scope of its reports and corrects possible misinterpretations.

- The Court of Audit's reports are published in the languages of the Parliamentary assemblies concerned.

- In its communication process, the Court of Audit ensures that data confidentiality is preserved.

\section{Publicity of the Court of Audit's reports}

The Court of Audit's communication policy is based on the public nature of its reports. However, the Parliamentary assemblies are the first to be informed of the Court's reports, before the media and the general public.

This policy relates to:

- information intended for the members of Parliament;

- information intended for the ministers and public authorities concerned;

- press relations;

- the handing over of the Court's reports to any interested person or organisation. 


\section{Products and practical implementation of the communication policy}

The Court of Audit's publications consist of an annual report on the accounts of the federal State, the Communities and the Regions, with the results of the audits conducted on these accounts, and of specific reports that are drawn up either under particular provisions or when the audits' results show a need for informing the Parliamentary assembly. The Court of Audit also publishes an annual activity report. These publications can be downloaded free from the website of the Court of Audit, as well as some data, accounts or audit results that are not recorded in an annual report or in a separate report and are only available in digital format.

This website is the most complete and current source of information about the reports published by the Court.

The Court of Audit issues press releases and organises press conferences to express its point of view and answer the questions of the press.

\section{Discussions with the Parliamentary Committee}

Representatives of the Court give a presentation of the audit results to the Parliamentary Committee. Responsible Members of Parliament can ask questions.

\section{Activity report}

In the past, the annual activity report has not been published. 2015 data will be included in the 2015 annual activity report of the court expected to be published soon at https://www.ccrek.be/EN/Publications/AnnualReports.html.

\section{3) Parliamentary procedures for SAI reports}

There are hearings held to which the auditee or other appropriate persons are invited to provide clarification or further information.

The debate on SAI reports is held in committee(s).

A Parliamentary document is produced to summarise a debate on a SAI report.

Parliament discusses and approves the general account act by way of granting discharge.

\section{Staffing}

Each Parliament decides in a sovereign way which Parliamentary committee deals with SAI reports and which procedures have to be followed.

Parliamentary documents produced as an outcome of a debate on a SAI report are written by Parliamentary staff supporting the committee(s). 


\section{SAl involvement in consideration of reports by Parliament}

Representatives of the Court (Member of the Court, Director, Supervisor and auditor(s)) give a presentation of the audit results to the competent Parliamentary committee. Members of Parliament can ask questions.

\section{4) SAI reports}

The Court makes recommendations to the auditee in audit reports, (see mission statement, only in French: $\underline{\text { http://www.ccrek.be/FR/DeclarationDeMission.htm). }}$.

The set up and functioning of internal control systems can be a subject that is highlighted in SAI reports.

All audit reports contain clear conclusions and audit opinions.

One of the main objectives of the Belgian Court of Audit is to ensure clear communication with stakeholders. To achieve this, the Belgian Court of Audit employs a team of communication experts whose role it is to support the auditors in drafting reports.

See: Ardelean, Veronica, European Court of Auditors, Clear language event at the European Court of Auditors, Journal of the European Court of Auditors, December 2015, p. 27, http://www.eca.europa.eu/Lists/ECADocuments/JOURNAL15 12/QJ-AD-15-0102A-C.pdf.

\section{5) Follow-up on SAI reports}

\section{Draft budgets}

SAI reports are regularly used as input for the annual debate on draft budgets.

See https://www.ccrek.be/EN/Presentation/Competences.html\#BudgetAnalysis.

\section{Follow-up on SAI reports}

The Court of Audit follows up audits regularly in order to ensure that recommendations issued have been considered by the auditees. Each financial audit report starts with a section that summarises the level of implementation of previous year's audits.

Each Parliament decides in a sovereign way how the Court of Audit's recommendations will be followed up.

For example, the Protocol agreement between the Flemish Parliament and the Belgian Court of Audit on 20 March 2012 (see Article 74 of the Rules of Procedure of the Flemish Parliament) stipulates that the Court shall compile an inventory, structured on the basis of each minister's policy letter, of the recommendations to which the Flemish Government is expected to respond. The inventory as a whole is sent to the Speaker of the Flemish Parliament, and each minister simultaneously receives the part of the inventory containing the recommendations on which he reports in his policy letters. A narrative report on the way the recommendations have been implemented is expected from the ministers. 


\section{6) Audits on Parliament's request}

Article 5, paragraph 1, 4 of the Act of 29 October 1846 organising the Court of Audit stipulates: "The House of Representatives may entrust the Court with audits on legality and regularity of some expenditure programmes as well as with financial audits in the departments and bodies subject to the Court's jurisdiction."

The last sub-paragraph of article 5, paragraph 1, of the Act of 29 October 1846 empowers the House of Representatives to entrust the Court of Audit with management audits in the departments and bodies subject to the Court's jurisdiction.

This legal provision has been recently applied.

\section{7) Work programme}

The SAI does not consult Parliament on its annual Work programme of audits.

There is no formal consultation with the Parliaments to determine the Work programme. However, the process of setting the annual operational programme and audit themes, the Court includes concerns expressed by the legislative assemblies during their debates and other activities (questions, resolutions, legislative initiatives).

\section{8) Level and frequency of contacts}

There is regular contact (including informal contact) between the Presidency of the Court and the Speaker of the Parliament.

\section{9) Good practice}

One of the main objectives of the Belgian Court of Audit is to ensure clear communication with stakeholders. In view of this, the Belgian Court of Audit employs a team of communication experts whose role it is to support the auditors in drafting reports.

See: Ardelean, Veronica, European Court of Auditors, Clear language event at the European Court of Auditors, Journal of the European Court of Auditors, December 2015, p. 27, http://www.eca.europa.eu/Lists/ECADocuments/JOURNAL15 12/QJ-AD-15-0102A-C.pdf. 


\title{
BOSNIA AND HERZEGOVINA
}

\author{
Supreme Audit Institution
}

\section{1) Legal framework}

Audit Act, Article 12 (Audit Planning): The Auditor General shall, after consulting with his/her deputies, adopt annual audit plan of the Audit Office for the next year, taking into account the requirements in accordance with this Act. The audit plan is submitted to the Parliamentary commission for information prior to the start of the new financial year.

Audit Act, Article 16 (Audit Reporting): The Audit Office shall submit a financial audit report to the auditee (within 90 days after submitting the auditee's annual report) and the Parliament.

For the audit of the annual report on budget execution, as provided for in Article 13, paragraph (5) of this Law, the Audit Office shall submit the audit report to the Parliament within 90 days after receipt of the annual report on the budget execution.

The Audit Office shall submit a performance audit report or a special audit report to the auditee and the Parliament within 30 days after completion of the audit.

The Audit Office shall collect key findings and recommendations from the conducted financial audits, performance audits and special audits in the annual audit report to Parliament (summary audit report). The annual audit report to Parliament must be submitted with the report on the audit of the annual report on the budget execution, as an integral part.

Audit Act, Article 17 (Additional Reporting): The Audit Office may, when it deems necessary, submit an additional audit report to Parliament on relevant issues.

Audit Act, Article 18 (Special Audits): The Parliament or a Parliamentary committee may, at any time, request the Audit Office to conduct a special audit. The Audit Office shall decide whether to carry out a special audit referred to in paragraph (1) of this Article, and shall notify the Parliament in writing, in accordance with Article 16 of this Law.

\section{2) SAI reporting practices}

The Audit Office submits to the Parliament individual financial audit reports (compliance included), performance audit reports, special reports, an annual report on key audit findings and recommendations (summary report), and an annual audit report on the State budget implementation. These reports are addressed to both Houses and competent Parliamentary committees of both Houses.

The Audit Office submits its financial reports on a quarterly and annual basis, as well as its annual activity report. These are addressed to the chair of the competent Parliamentary committee.

The Audit Office also submits to the Parliament reports on its professional assessment (peer review report), including a report on the measures the Audit Office has taken as a result of this evaluation. This report is addressed to the chair of the competent Parliamentary committee. 


\section{Procedures for sending reports to Parliament}

There are no written specific procedures for the Audit Office. The Auditor General presents key findings from audit reports before the Parliamentary committee during the debate on audit reports.

\section{Number and type of reports}

\begin{tabular}{|c|c|c|c|c|c|c|c|}
\hline & $\begin{array}{l}\text { Financial } \\
\text { audit } \\
\text { reports }\end{array}$ & $\begin{array}{l}\text { Compliance } \\
\text { audit reports }\end{array}$ & $\begin{array}{l}\text { Performance audit } \\
\text { reports }\end{array}$ & $\begin{array}{l}\text { Other reports } \\
\text { or documents }\end{array}$ & $\begin{array}{l}\text { Annual } \\
\text { activity } \\
\text { reports }\end{array}$ & $\begin{array}{l}\text { Reports at } \\
\text { request of } \\
\text { Parliament }\end{array}$ & Remarks \\
\hline Number submitted & 73 & & 4 & & 1 & 1 & $\begin{array}{c}\text { Compliance } \\
\text { audit is } \\
\text { performed } \\
\text { as part of } \\
\text { financial } \\
\text { audit }\end{array}$ \\
\hline $\begin{array}{c}\text { Number discussed } \\
\text { by Parliament }\end{array}$ & 73 & & 4 & & 1 & 1 & \\
\hline $\begin{array}{l}\text { Submitted to } \\
\text { Speaker }\end{array}$ & $\bar{Y}$ & & $\bar{Y}$ & & $\mathrm{~N}$ & $\bar{Y}$ & \\
\hline $\begin{array}{l}\text { Submitted to Chair } \\
\text { of dedicated } \\
\text { committee }\end{array}$ & $Y$ & & $\bar{Y}$ & & $\bar{Y}$ & $\mathrm{Y}$ & \\
\hline $\begin{array}{l}\text { Copied to other } \\
\text { relevant } \\
\text { committees }\end{array}$ & $\mathrm{N}$ & & $\mathrm{N}$ & & $\mathrm{N}$ & $\mathrm{N}$ & \\
\hline $\begin{array}{l}\text { Briefings organised } \\
\text { for Parliamentary } \\
\text { committee }\end{array}$ & $\mathrm{Y}$ & & $\mathrm{Y}$ & & $\mathrm{N}$ & $Y$ & \\
\hline $\begin{array}{l}\text { Summaries } \\
\text { submitted to } \\
\text { Parliament }\end{array}$ & $Y$ & & $Y$ & & $\mathrm{~N}$ & 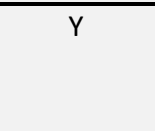 & \\
\hline
\end{tabular}

\section{3) Parliamentary procedures for SAI reports}

There are fixed procedures for handling SAI reports laid down in Parliament's Guidelines for Review and Analysis of Audit Reports. These refer only to financial audit reports. There are no such procedures for performance audit reports.

There is a dedicated committee (The Finance and the Budget Committee) for handling SAl reports at both Houses of the Parliament. It is chaired by a member of the government party/parties (procedure based).

The committee appoints a rapporteur for a specific audit report. 
There are hearings held to which the auditee or other appropriate persons are invited to provide clarification or further information.

The debate on SAI reports is held both in committee(s) and plenary.

Other committees, apart from any dedicated committee, do consider individual reports of the SAI if they tackle the issues within their competence.

A report of the conclusions of the Parliamentary debate on a SAI report is published on the Parliament's website.

The Parliament has a fixed procedure for discharge which is being followed in practice. SAl reports play a role in this procedure.

\section{Staffing}

Both Houses deal with SAI reports through the Finance and Budget Committee. The committee members are supported by the Secretary of the Committee plus one or two support staff. The Secretary is responsible to provide briefings, analyses, and questions, as well as draft conclusions as outputs of the committee's review of SAl's reports.

\section{SAI involvement in consideration of reports by Parliament}

The Auditor General (accompanied by other relevant staff) attend Parliamentary meetings when SAI reports are debated and presents key findings and recommendations from debated audit reports. The SAI staff is also available for any clarifications needed during the debate.

\section{4) SAI reports}

The SAI makes a report annually to the Parliament, listing all systems problems found during the audits. The report proposes measures to strengthen the systems, and to improve the transparency and efficiency of public spending. Financial audit reports specifically deal with internal control systems of auditees, with a separate heading dedicated to internal control. All financial audit reports contain a clear opinion on financial statements and compliance, and all performance audit reports contain clear conclusions.

\section{5) Follow-up on SAI reports}

The SAI keeps records of conclusions and recommendations given to auditees and the level of their implementation in an excel file, which is updated on a regular basis).

The Parliament regularly issues conclusions for auditees to implement the SAI's recommendations, but it lacks mechanisms to follow up the implementation of the conclusions. This is why the level of the SAl's recommendations implementation is rather low (50-60\%).

Financial audits have two stages. During the interim audit stage, the implementation of recommendations from previous audits is reviewed. Measures taken on the basis of these recommendations are analysed. The final financial audit reports all include a separate heading addressing the level of the implementation of the recommendations given for the previous year. The heading usually includes three sub-headings: recommendations implemented, implementation of recommendations in 
progress, and recommendations not implemented. This approach includes implementation of recommendations related to the internal control system as well.

The auditee reports to the Auditor General and the Ministry of Finance within 60 days of receipt of the audit report, specifying actions taken to overcome the weaknesses, irregularities and non-compliance identified in the audit report.

The Parliament may, on the basis of the findings and recommendations in the annual audit report and/or annual report on the budget execution, reduce the budget of one or more budget users or take other corrective actions. SAl's reports are used very often as basis for debate on draft budgets, especially for auditees with qualified opinions.

\section{6) Audits on Parliament's request}

The legal provision is in Article 18 (please see response 1). The SAI has a discretionary right to decide whether or not to perform a special audit requested by the Parliament. The Parliament does not use the provision very often. There has been only one audit requested by the Parliament in the last five years. The SAI has never rejected to perform an audit requested.

\section{7) Work programme}

The Auditor General adopts an annual work plan, after consulting with his/her deputies, taking into account the requirements of the Act (e.g. audits requested by the Parliament). The audit plan is submitted to the Parliamentary commission for information before the start of the new financial year.

\section{8) Level and frequency of contacts}

There are regular, working level contacts between relevant SAI staff (there is no unit specifically tasked with Parliamentary relations) and support staff of dedicated Parliamentary committees. The frequency of these contacts depends on the needs of the SAI or the Parliament.

\section{9) Good practice}

Written procedures for reviewing financial audit reports have definitely increased the efficiency of Parliamentary review of audit report and understanding of audit by the MPs.

\section{0) Perspective}

There is a lack of written procedures for reviewing performance audit reports.

The lack of Parliamentary mechanism to follow up implementation of audit recommendations by auditees makes the impact of SAl's work and its reports less efficient.

There are outline plans to develop written guidelines for reviewing performance audit reports in order to both make the impact of these reports stronger and to increase the understanding within the Parliament.

These activities should and must include the aspect of the implementation of the SAl's recommendations, with Parliamentary procedures to follow up the implementation and make the auditees accountable for failures to implement the SAI's recommendations.

There is also a need to educate the MPs regularly on the principles of public sector auditing, especially having in mind the four year Parliamentary term. 
11) Are there any other relevant features of the current relations between the SAI and Parliament that you would like to highlight, and how have they evolved over the past five years?

We would like to highlight the issue of SAl's independence. The Parliament should be educated not to pass laws and regulations which undermine the independence of the Audit Office, and MPs should be more aware of the significance of the SAl independence. 


\section{BULGARIA}

National Audit Office

\section{1) Legal framework}

Under the Constitution of the Republic of Bulgaria, the National Assembly set up a Supreme Audit Institution to oversee the implementation of the budget.

The organisation, authority and procedures of the Bulgarian National Audit Office (BNAO) are defined in the National Audit Office Act.

The BNAO's obligations to Parliament are set out in a chapter in the Act related to the accountability and control of its work.

The BNAO presents the following reports to Parliament:

1. Reports with opinions on the statements of the implementation of the State budget, the budget of the public social security scheme, the budget of the National Health Insurance Fund, and on the budget expenditure of the Bulgarian National Bank (BNB) for the preceding year.

2. Reports of audits performed on budget systems, or with significant results for the respective budgets and other public resources and activities.

3. Reports of audits performed under a decision of the National Assembly.

The National Assembly or one of its Committees can ask the BNAO to submit specific audit reports.

The BNAO may make proposals to the National Assembly and its specialised committees to examine audit reports of particular significance for the improvement of budget discipline and the management of the budget and/or other public funds and activities.

By 30 September the BNAO submits to the National Assembly an activity report for the preceding year.

The annual financial statement of the BNAO is audited by an independent committee with no less than two registered auditors. The number of members and the composition of the committee is determined by the National Assembly. The report of the committee on the statement is submitted to the National Assembly, together with the activity report of the BNAO for the corresponding year. The BNAO President can express a written opinion on the report, and the opinion is attached to the report submitted to the National Assembly. The report and the BNAO's President's opinion is made public after being adopted by the National Assembly.

\section{2) SAI reporting practices}

The general framework for reporting is set out in the previous section.

A special report with findings and recommendations from performance audits on EU Funds management is submitted to the European affairs and oversight of the European Funds Committee.

If mistakes and incorrectness come to light which have a substantial effect on the indicators of the report for implementation of the State budget, the BNAO shall notify the corrections to be made in the report to 
the Minister of Finance and the Commission in the National Assembly, which is responsible for the budget.

Under the Act on the financial management and control in the public sector, the BNAO submits to the National Assembly its report on the condition of the financial management and control systems, and the internal audit and opinions on the reports by 30 June.

\section{Procedures for sending reports to Parliament}

There are no specific procedures in respect of the sending the reports to the Parliament.

\section{Number and type of reports}

\begin{tabular}{|c|c|c|c|c|c|c|c|}
\hline & $\begin{array}{l}\text { Financial } \\
\text { audit } \\
\text { reports }\end{array}$ & $\begin{array}{l}\text { Compliance } \\
\text { audit reports }\end{array}$ & $\begin{array}{c}\text { Performance audit } \\
\text { reports }\end{array}$ & $\begin{array}{l}\text { Other reports } \\
\text { or documents }\end{array}$ & $\begin{array}{l}\text { Annual } \\
\text { activity } \\
\text { reports }\end{array}$ & $\begin{array}{l}\text { Reports at } \\
\text { request of } \\
\text { Parliament }\end{array}$ & Remarks \\
\hline Number submitted & 1 & 3 & 10 & 1 & 1 & 1 & \\
\hline $\begin{array}{l}\text { Number discussed } \\
\text { by Parliament }\end{array}$ & & & 1 & & & & \\
\hline $\begin{array}{c}\text { Submitted to } \\
\text { Speaker }\end{array}$ & $\mathrm{N}$ & $\mathrm{N}$ & $\mathrm{N}$ & $\mathrm{N}$ & $\mathrm{N}$ & $\mathrm{N}$ & \\
\hline $\begin{array}{l}\text { Submitted to Chair } \\
\text { of dedicated } \\
\text { committee }\end{array}$ & $\mathrm{Y}$ & $Y$ & $Y$ & $\mathrm{Y}$ & $Y$ & $\mathrm{Y}$ & \\
\hline $\begin{array}{l}\text { Copied to other } \\
\text { relevant } \\
\text { committees }\end{array}$ & $\mathrm{Y}$ & $Y$ & $Y$ & $\bar{Y}$ & $\mathrm{Y}$ & $\bar{Y}$ & \\
\hline $\begin{array}{l}\text { Briefings organised } \\
\text { for Parliamentary } \\
\text { committee }\end{array}$ & $\mathrm{N}$ & $\mathrm{N}$ & $\mathrm{N}$ & $\mathrm{N}$ & $\mathrm{N}$ & $\mathrm{N}$ & \\
\hline $\begin{array}{c}\text { Summaries } \\
\text { submitted to } \\
\text { Parliament }\end{array}$ & $\mathrm{N}$ & $\mathrm{N}$ & $\mathrm{N}$ & $\mathrm{N}$ & $\mathrm{N}$ & $\mathrm{N}$ & \\
\hline
\end{tabular}

\section{3) Parliamentary procedures for SAI reports}

A debate on the submitted SAI reports is held in the respective Parliamentary committees.

A Public Sector Accountability Subcommittee to the Budget and Finance Committee has Parliamentary control, but there are no fixed procedures for handling BNAO's reports. 


\section{Staffing}

In general, the members of standing committees in implementation of their duties are supported by assistants, but they are not specifically hired for dealing with SAI reports.

\section{SAl involvement in consideration of reports by Parliament}

BNAO representatives attend Parliamentary committee meetings when audit reports are debated, represented by its management and the head of the audit team. They present the main audit findings, conclusions and recommendations, and answer questions.

\section{4) SAI reports}

The main findings, conclusions and recommendations from the audits are presented during the standing committees' debates.

The set up and functioning of the internal control systems is checked during performance and compliance audits.

The compliance audit and performance audit reports contain clear conclusions, while the financial audit reports contain audit opinions.

\section{5) Follow-up on SAI reports}

Follow-up on recommendations is performed under rules covering the organisation and control of the implementation of recommendations of the BNAO.

The control of the implementation of recommendations is a compulsory stage of each audit if there are recommendations.

The follow-up aims at verifying the activities of the heads of the audited organisations to implement the recommendations of the BNAO. The follow-up includes a systematic review and analyses of the recommendations in different areas, assessing the activity for improving the management of the budget and other public funds and activities.

If recommendations are not implemented, the relevant bodies are informed promptly.

An electronic Register of the recommendations is maintained to keep track of recommendations.

If a recommendation is not implemented, the BNAO makes a report with proposals to the National Assembly, the Council of Ministers or the respective municipality council to undertake the necessary actions.

Any failure to implement recommendations made is announced on the website of the BNAO.

\section{6) Audits on Parliament's request}

The National Assembly can assign the BNAO to carry out up to five audits a year outside the audits envisaged in the annual programme. 
In 2015 the National Assembly asked for an audit on banking supervision after public attention was focused on the difficult situation in which one bank had been placed. In pursuance of the National Assembly's decision the BNAO carried out a performance audit on the effectiveness and efficiency of the banking supervision by the Bulgarian National Bank for the period 1 January 2012 to 31 December 2014.

\section{7) Work programme}

The annual audit programme is adopted by the BNAO without consulting the National Assembly.

The annual audit programme is submitted to the National Assembly within 7 days of its adoption or amendment.

The National Assembly can ask the BNAO to carry out up to five audits a year outside the audits envisaged in the annual programme.

\section{8) Level and frequency of contacts}

The Head of the BNAO maintains contact with the Chairperson of the Budget and Finance Committee and with the Public Sector Accountability Subcommittee on a monthly basis.

The Head of Cabinet of the President of the BNAO is responsible for keeping relations with the Parliament.

\section{9) Good practice}

As a result of an audit carried out by the BNAO on the activity of the Ministry of Finance on the organisation and management of the budgeting process, a new act on the public finances was adopted by the National Assembly

\section{0) Perspective}

The National Assembly should review the reports with opinions on the statements of the implementation of the State budget, the budget of the public social security scheme, the budget of the National Health Insurance Fund, the budget expenditure of the BNB, and the reports of audits performed after a decision of the National Assembly within three months from their submission date.

In general, the set term is not being observed and some of the reports submitted are not being reviewed.

The BNAO will work towards setting up mechanisms that establish the reports which will have opinions on the statements of implementation of the State budget, the budget of the public social security scheme and the budget of the National Health Insurance Fund to be taken into consideration before adoption of the respective budgets for the next years by the National Assembly.

Another objective is to build co-operation between the new Fiscal Council and the BNAO about the opinions on the State budget implementation and the implementation of the budgets of the autonomous institutions like the National Health Insurance Fund. 


\section{CROATIA}

State Audit Office

\section{1) Legal framework}

The Legal framework regulating relations between the Croatian State Audit Office (SAO) and the Croatian Parliament is set out in the State Audit Office Act (OG 80/11), the Political Activity and Electoral Campaigne Financing Act (OG 24/11, 61/11, 27/13 i 48/13 - revised text), and the Standing Orders of the Croatian Parliament.

\section{2) SAI reporting practices}

The SAO delivers to the Croatian Parliament an annual work report and other audit reports (individually or in groups of reports). All reports are submitted to the Speaker of the Parliament.

Deadline for submission of the SAO's annual work report is set out in Article 15 of the State Audit Office Act. The Auditor General reports to the Croatian Parliament on the work of the SAO at the end of the year for the reporting year that begins on 1 October of the preceding year and ends on 30 September of the current year. In addition to the annual report, the SAO also submits reports on the audits carried out in this reporting period.

The obligation to submit the Audit Report on the Execution of the State Budget to the Croatian Parliament is also set out by the State Audit Office Act, by 1 June of the current year for the previous year.

Reports on the audit of political parties, independent representatives and independent members of representative bodies of local government units, are submitted to the Croatian Parliament by the end of the current year for the previous year, in line with the Law on the financing of political activities and election campaigns.

\section{Procedures for sending reports to Parliament}

The SAO has the procedures for sending reports to the Parliament, while the procedures related to the handling of audit reports within Parliament are based on the Rules of Procedure (Standing Orders) of the Croatian Parliament.

Representatives of the SAO attend committees' debates on audit reports, and in the opening speech present the results of the audit.

The audit reports are discussed at the plenary session too, also attended by the representatives of the SAO including the Auditor General, who gives the introductory speech. 
Number and type of reports

\begin{tabular}{|c|c|c|c|c|c|c|c|}
\hline & $\begin{array}{l}\text { Financial } \\
\text { audit } \\
\text { reports }\end{array}$ & $\begin{array}{l}\text { Compliance } \\
\text { audit reports }\end{array}$ & $\begin{array}{c}\text { Performance audit } \\
\text { reports }\end{array}$ & $\begin{array}{l}\text { Other reports } \\
\text { or documents }\end{array}$ & $\begin{array}{l}\text { Annual } \\
\text { activity } \\
\text { reports }\end{array}$ & $\begin{array}{l}\text { Reports at } \\
\text { request of } \\
\text { Parliament }\end{array}$ & Remarks \\
\hline Number submitted & 237 & 0 & 36 & $\begin{array}{l}141 \text { review of } \\
\text { financial } \\
\text { reports } \\
+ \\
28 \text { follow-up } \\
\text { audits }\end{array}$ & 1 & 0 & \\
\hline $\begin{array}{c}\text { Number discussed } \\
\text { by Parliament }\end{array}$ & 237 & - & 36 & $(141+28)^{*}$ & 1 & - & $\begin{array}{c}\text { *Within } \\
\text { discussion on } \\
\text { annual work } \\
\text { report }\end{array}$ \\
\hline $\begin{array}{l}\text { Submitted to } \\
\text { Speaker }\end{array}$ & $Y$ & - & $Y$ & $Y$ & $Y$ & - & \\
\hline $\begin{array}{l}\text { Submitted to Chair } \\
\text { of dedicated } \\
\text { committee }\end{array}$ & $Y$ & - & $Y$ & $Y$ & $Y$ & - & \\
\hline $\begin{array}{l}\text { Copied to other } \\
\text { relevant } \\
\text { committees }\end{array}$ & $\mathrm{Y}^{*}$ & - & $\mathrm{Y}^{*}$ & $\mathrm{Y}^{*}$ & $\mathrm{Y}^{*}$ & - & $\begin{array}{c}{ }^{*} \text { Distribution to } \\
\text { the relevant } \\
\text { committees is } \\
\text { organised } \\
\text { within the } \\
\text { Parliament }\end{array}$ \\
\hline $\begin{array}{c}\text { Briefings organised } \\
\text { for Parliamentary } \\
\text { committee }\end{array}$ & $n$ & - & $\mathrm{N}$ & $\mathrm{n}$ & $n$ & - & \\
\hline $\begin{array}{c}\text { Summaries } \\
\text { submitted to } \\
\text { Parliament }\end{array}$ & $\mathrm{Y}^{*}$ & - & $\mathrm{Y}^{*}$ & $\mathrm{Y}^{*}$ & $\mathrm{Y}^{*}$ & - & $\begin{array}{c}\text { *Summaries are } \\
\text { regular part of } \\
\text { each audit } \\
\text { report }\end{array}$ \\
\hline
\end{tabular}

\section{3) Parliamentary procedures for SAI reports}

After discussion at the plenary session, the Croatian Parliament reach a conclusion, which obliges the Government to reflect in a certain period of time on the implementation of the recommendations of the SAO. This document is published on the Parliament's web site (as are all other conclusions).

All plenary sessions are fully broadcasted ("live") on the web site of the Croatian Parliament, which means that all debates and conclusions are fully transparent to the public. 


\section{Staffing}

Parliamentary committees are in general supported by a small number of staff, who help in the preparation of documents and information needed for debates, and in preparation of committees' opinions for the plenary session.

\section{SAI involvement in consideration of reports by Parliament}

The SAO gives any explanations about the audit reports before debates. Representatives of the SAO also regularly attend Parliamentary meetings when SAO's reports are debated.

Representatives of the State Audit Office attend discussions in the committees, and in the opening speech present the results of the audit. Meetings of the committees involve: the Auditor General (always at the meetings of the Committee for Finance and Budget, and on the other committees depending on the topic), Deputy Auditor General and audit coordinators.

The audit reports are discussed at the plenary session too, also attended by the representatives of the SAO including the Auditor General, who gives the introductory speech.

\section{4) SAI reports}

In communication with the Parliament the SAO is focusing on system problems.

The system of evaluation of the internal control is an integral part of each audit. Based on the assessment of the internal financial controls, state auditors determine risk areas.

All audit reports contain clear conclusions (performance audits) and opinions (financial audit).

\section{5) Follow-up on SAI reports}

There are several ways and levels of follow-up:

The legal representative of the audited entity sends an official response to the SAO on actions taken about the audit findings no more than 60 days after the receipt of the audit report.

Implementation of SAO's recommendations is checked in each audit as a regular part of audit procedures. Each audit report contains information on findings and recommendations from previous audits, showing which of them have been implemented, which are in the process of execution and for which there was no action.

The SAO's annual work report shows for each group of audited subjects how many recommendations have been given, how many of them have been implemented, in the process of implementation or not implemented. Information on findings and recommendations related to the internal control systems are given too.

The SAO also conducts special follow-up audits (see: annual work report, www.revizija.hr)

Finally, the Croatian Parliament also analyses the recommendations and their implementation. 


\section{6) Audits on Parliament's request}

The provisions of the Act on the SAO, allows audits to be carried out upon request of the Croatian Parliament, if Auditor General assesses the request as justified. Since the adoption of the Act on the SAO, the Croatian Parliament has not asked for an audit.

\section{7) Work programme}

There are no consultations with the Parliament about the audit plan. Article 9 of the Act on the SAO states that the Auditor General brings the strategic plan and annual working program of the SAO to Parliament.

\section{8) Level and frequency of contacts}

There are regular contacts in the sessions of the Committee for Finance and Budget and other committees, to discuss the reports of the SAO during the year. Meetings are attended by the Auditor General (always at the meetings of the Committee for Finance and Budget, and on the other committees depending on the topic), Deputy Auditor General and audit coordinators.

\section{9) Good practice}

Three years ago, at the initiative of the SAO, the Committee for Finance and Budget agreed a change in the frequency of submission of reports to the Parliament and of their publication. This was because of the obligations arising from the new Law on the Freedom of Information, and in order to improve the efficiency and quality of communication between the Croatian Parliament and the SAO. As a result, the SAO submits audit reports to the Parliament immediately after they are completed and publish them on the websites almost simultaneously.

\section{0) Perspective}

There are no weak points; only areas with a potential to be improved, such as:

Setting up of a Parliamentary committee/sub-committee for audit, dealing specifically with the SAO's audit reports.

Inviting of responsible persons from auditees to the committees' debates on audit reports as normal practice.

The SAO has started discussion on both issues with the Speaker of the Parliament as well as with the Head and members of the Committee for Finance and State Budget. The SAO organised a study trip for a group of MPs to the UK NAO and British Parliament to present their communication and way of operations as an example of Good practice.

11) Are there any other relevant features of the current relations between the SAI and Parliament that you would like to highlight, and how have they evolved over the past five years.

See Sections 9 and 10. 


\section{CYPRUS $^{1}$}

Audit Office of the Republic of Cyprus

\section{1) Legal framework}

The Legal framework in respect to the SAl's obligations to Parliament is set out in the Constitution of the Republic of Cyprus. The Auditor General is required to submit the Annual Report to the President of the Republic who has to lay it before Parliament.

\section{2) SAI reporting practices}

The SAI of Cyprus submits an Annual Report which includes, in summary form, the findings and recommendations of all its work (financial audits, compliance audits, performance audits). Separate detailed reports are submitted to Parliament about the audit of the major statutory bodies as required by the relevant laws.

\section{Procedures for sending reports to Parliament}

There are no specific procedures for sending reports to Parliament other than those stipulated in the Constitution. The Auditor General regularly attends the meetings of the Public Accounts Committee where issues about the Annual Report or any other issues are discussed.

\footnotetext{
Note by Turkey

The information in this document with reference to "Cyprus" relates to the southern part of the Island. There is no single authority representing both Turkish and Greek Cypriot people on the Island. Turkey recognises the Turkish Republic of Northern Cyprus (TRNC). Until a lasting and equitable solution is found within the context of the United Nations, Turkey shall preserve its position concerning the "Cyprus issue".

Note by all the European Union Member States of the OECD and the European Union

The Republic of Cyprus is recognised by all members of the United Nations with the exception of Turkey. The information in this document relates to the area under the effective control of the Government of the Republic of Cyprus.
} 


\section{Number and type of reports}

\begin{tabular}{|c|c|c|c|c|c|c|c|}
\hline & $\begin{array}{l}\text { Financial } \\
\text { audit } \\
\text { reports }\end{array}$ & $\begin{array}{l}\text { Compliance } \\
\text { audit reports }\end{array}$ & $\begin{array}{c}\text { Performance audit } \\
\text { reports }\end{array}$ & $\begin{array}{l}\text { Other reports } \\
\text { or documents }\end{array}$ & $\begin{array}{l}\text { Annual } \\
\text { activity } \\
\text { reports }\end{array}$ & $\begin{array}{l}\text { Reports at } \\
\text { request of } \\
\text { Parliament }\end{array}$ & Remarks \\
\hline Number submitted & 10 & $\begin{array}{l}\text { Included in the } \\
\text { Annual Report }\end{array}$ & 2 & -- & -- & & \\
\hline $\begin{array}{c}\text { Number discussed } \\
\text { by Parliament }\end{array}$ & 10 & As above & 2 & -- & -- & & \\
\hline $\begin{array}{c}\text { Submitted to } \\
\text { Speaker }\end{array}$ & $\mathrm{N}$ & $\mathrm{N}$ & $\mathrm{N}$ & $\mathrm{N}$ & $\mathrm{N}$ & & \\
\hline $\begin{array}{l}\text { Submitted to Chair } \\
\text { of dedicated } \\
\text { committee }\end{array}$ & $\mathrm{N}$ & $\mathrm{N}$ & $\mathrm{N}$ & $\mathrm{N}$ & $\mathrm{N}$ & & \\
\hline $\begin{array}{l}\text { Copied to other } \\
\text { relevant } \\
\text { committees }\end{array}$ & $\mathrm{N}$ & $\mathrm{N}$ & $\mathrm{N}$ & $\mathrm{N}$ & $\mathrm{N}$ & & \\
\hline $\begin{array}{l}\text { Briefings organised } \\
\text { for Parliamentary } \\
\text { committee }\end{array}$ & $\mathrm{N}$ & $\mathrm{N}$ & $\mathrm{N}$ & $\mathrm{N}$ & $\mathrm{N}$ & & \\
\hline $\begin{array}{c}\text { Summaries } \\
\text { submitted to } \\
\text { Parliament }\end{array}$ & $\mathrm{N}$ & $\mathrm{N}$ & $\mathrm{N}$ & $\mathrm{N}$ & $\mathrm{N}$ & & \\
\hline
\end{tabular}

\section{3) Parliamentary procedures for SAI reports}

When the Public Accounts Committee receives the annual report, it initiates proceedings to discuss the Report with the line ministries and the major semi-government organisations. These are all attended by the Auditor General. The auditees and other interested parties are invited to attend the meetings and to give their explanations to the committee.

\section{Staffing}

There are MPs from all parties in the Public Accounts Committee, and they have their personal assistants. The Secretary of the Public Accounts Committee, in consultation with the members of the committee, prepares questions to facilitate the debates.

\section{SAl involvement in consideration of reports by Parliament}

The Auditor General attends all the meetings of the Public Accounts Committee and is actively involved in the debate with a view to resolving the issues in the reports. 


\section{4) SAI reports}

The Internal Control System of the auditees is scrutinised, and any weaknesses are reported and included in the annual report.

\section{5) Follow-up on SAI reports}

The SAI monitors the conclusions and recommendations that it gives to auditees on a regular basis. It is a legal requirement that the auditees provide a statement of compliance with the recommendations of the SAI with their annual budget, which is submitted for approval to Parliament.

\section{6) Audits on Parliament's request}

There is no legal provision for Parliament to ask for an audit because the SAI is independent. However, there is close co-operation between our SAI and Parliament and any suggestion by Parliament for a specific audit is accommodated.

\section{7) Work programme}

The SAI does not consult Parliament on its annual Work programme of audits.

\section{8) Level and frequency of contacts}

The Auditor General attends the meetings of the Public Accounts Committee regularly, on a weekly basis.

\section{9) Good practice}

The SAI and the Auditor General maintain close contact with the Chair of the Public Accounts Committee. Any request for an audit/investigation by a member of the committee is followed up promptly. 


\section{THE CZECH REPUBLIC}

Supreme Audit Office

\section{1) Legal framework}

The Czech Supreme Audit Office (SAO) is obligated by the Supreme Audit Office Act No. 166/1993 to send its annual audit plan, annual report, Statement to the State Final Account, Statement to the Report on economy development and the implementation of the State Budget and all audit reports to the government. The same documents have to go to both Chambers of the Parliament, the Chamber of Deputies (lower chamber) and the Senate (upper chamber).

In common practice these reports are sent to the Prime Minister and the Chairs of both Chambers. When asked by any Chamber or their bodies (e.g. a committee), the SAO draws up within an agreed term its opinion on proposed legal regulations on budget management, accounting, state statistics and performance of auditing, supervisory and inspection activities. The SAO President may attend meetings of both Chambers or of their bodies when they discuss proposals and opinions submitted to them by the SAO. The SAO President has a right to speak at the meeting. When either Chambers or their bodies ask the SAO President to come to their meetings, he must attend. The SAO President may also attend the meeting of the government while audit reports are discussed. The SAO President has a right to speak at the meeting.

\section{2) SAI reporting practices}

The SAO carries out approximately 40 audits per year. For each audit there is one single audit report, which the SAO Act calls it an audit conclusion. The audit conclusion is a written report summing up and evaluating the facts ascertained in the course of an audit carried out. The audit conclusion is public. The audit reports are sent to the government and to both Chambers of the Parliament after their approval of the SAO Board. The government, both Chambers of the Parliament or their bodies may also ask to receive audit protocols. The audit protocol includes a description of the facts and list the defects found, and specifies the legal regulations which have been violated. The audit protocol is not public and it acts as the basis for the audit conclusion (public audit report). The government discusses all audit reports. In the Parliament the audit reports are discussed in the Committee on the Budget Control. It is a committee of the Chamber of Deputies which is created by law and it is formed each election period. It is up to the committee how many audit reports it will discuss. In 2015 they discussed 25 audit reports and in 2014 it was 13 audit reports. Other committees discuss audit reports very rarely.

The audit report is officially sent to the Chair of the Chamber, who then sends it to the Committee on Budget Control. The SAO very closely co-operates with this committee.

The annual audit plan is sent to the Parliament after its approval by the SAO Board by the end of the calendar year.

The annual report is sent to the Parliament by 31st March. It is discussed in the Committee on Budget Control, and also in the upper chamber of the Parliament.

The Statement to the State Final Account is sent to the Parliament four months after the government submits the State Final Account to the Chamber of Deputies. 
The Statement to the Report on economy development and the implementation of the State Budget is sent to the Parliament a month after the government submits the report to the Chamber of Deputies.

\section{Procedures for sending reports to Parliament}

See above for procedures for sending reports to Parliament.

\section{Number and type of reports}

\begin{tabular}{|c|c|c|c|c|c|c|c|}
\hline & $\begin{array}{l}\text { Financial } \\
\text { audit } \\
\text { reports }\end{array}$ & $\begin{array}{l}\text { Compliance } \\
\text { audit reports }\end{array}$ & $\begin{array}{c}\text { Performance audit } \\
\text { reports }\end{array}$ & $\begin{array}{l}\text { Other reports } \\
\text { or documents }\end{array}$ & $\begin{array}{l}\text { Annual } \\
\text { activity } \\
\text { reports }\end{array}$ & $\begin{array}{l}\text { Reports at } \\
\text { request of } \\
\text { Parliament }\end{array}$ & Remarks \\
\hline Number submitted & 4 & 30 & 6 & 2 & 1 & 0 & \\
\hline $\begin{array}{c}\text { Number discussed } \\
\text { by Parliament }\end{array}$ & 4 & 16 & 5 & 2 & 1 & 0 & $\begin{array}{c}\text { Audit } \\
\text { reports are } \\
\text { discussed } \\
\text { not only in } \\
\text { the same } \\
\text { year when } \\
\text { the SAO } \\
\text { sent them } \\
\text { to the } \\
\text { Parliament }\end{array}$ \\
\hline $\begin{array}{l}\text { Submitted to } \\
\text { Speaker }\end{array}$ & $\bar{Y}$ & $\bar{Y}$ & $\bar{Y}$ & $\bar{Y}$ & $\bar{Y}$ & $\mathrm{Y}$ & \\
\hline $\begin{array}{c}\text { Submitted to Chair } \\
\text { of dedicated } \\
\text { committee }\end{array}$ & $\mathrm{N}$ & $\mathrm{N}$ & $\mathrm{N}$ & $\mathrm{N}$ & $\mathrm{N}$ & $\mathrm{N}$ & $\begin{array}{c}\text { The audit } \\
\text { report is } \\
\text { officially } \\
\text { sent to the } \\
\text { Chair of the } \\
\text { Chamber, } \\
\text { who sends it } \\
\text { to the } \\
\text { Committee } \\
\text { on Budget } \\
\text { Control }\end{array}$ \\
\hline $\begin{array}{l}\text { Copied to other } \\
\text { relevant } \\
\text { committees }\end{array}$ & $\mathrm{N}$ & $\mathrm{N}$ & $\mathrm{N}$ & $\mathrm{N}$ & $\mathrm{N}$ & $\mathrm{N}$ & \\
\hline $\begin{array}{c}\text { Briefings organised } \\
\text { for Parliamentary } \\
\text { Committee }\end{array}$ & $\mathrm{N}$ & $\mathrm{N}$ & $\mathrm{N}$ & $\mathrm{N}$ & $\mathrm{N}$ & $\mathrm{N}$ & \\
\hline $\begin{array}{c}\text { Summaries } \\
\text { submitted to } \\
\text { Parliament }\end{array}$ & $\mathrm{N}$ & $\mathrm{N}$ & $\mathrm{N}$ & $\mathrm{N}$ & $\mathrm{N}$ & $\mathrm{N}$ & \\
\hline
\end{tabular}




\section{3) Parliamentary procedures for SAI reports}

In Parliament, the audit reports are discussed in the Committee on Budget Control. It is the committee of the Chamber of Deputies which is created by law, and it is formed each election period. It was created for the first time in 2006. Traditionally, it is chaired by a member of the opposition of the ruling party or a coalition. It is up to the committee how many audit reports it will discuss. In 2015 it was 25 audit reports and in 2014 it was 13 audit reports.

Other committees discuss the audit reports very rarely (one or two audit reports per election period).

The SAO President, the SAO member who conducted the particular audit and also the representatives of the auditee are invited to the meeting of the Committee on Budget Control when the SAO audit reports are discussed. The representatives of the auditee are mainly the Deputy Minister, or sometimes another Minister.

For each discussed audit report the Committee on Budget Control adopts its resolution.

One of the committee members is chosen in advance as the rapporteur. He or she consults mainly with the SAO member who conducted the particular audit. The committee can also use independent external experts, it can ask for their statement and also to invite them to the committee meeting. The meetings of the committee are public. The committee can also ask for any material (even confidential) from the auditee.

\section{Staffing}

The staff of the Committee on Budget Control consists of three people. They provide only administrative support. Expert support is provided either by the SAO, or by the auditees, or by independent external experts.

\section{SAI involvement in consideration of reports by Parliament}

The committee meeting to discuss the SAO audit reports includes the SAO President, the SAO member who conducted the particular audit, and the auditors who participated in the audit.

The member of the committee (the rapporteur) can ask for the assistance of the SAO staff in advance.

\section{4) SAI reports}

The SAO performs approximately 40 audits per year. For each audit there is one single audit report which the SAO Act calls an audit conclusion. The audit conclusion is a written report summing up and evaluating the facts ascertained in the course of an audit carried out. The public audit report sums up the system findings. All audit reports contain conclusion.

Besides other reports, statements and other materials, the SAO produces an EU report each year, e.g. the Report on the EU Financial Management in the Czech Republic.

\section{5) Follow-up on SAI reports}

The SAO evaluates the remedial measures proposed and adopted by the auditees. 
The government discusses all audit reports. The government adopts its resolution to each audit report. Most of the resolutions require a particular Ministry to adopt remedial measures (in 2015 it was in $88 \%$ cases, in 2014 in 86\% cases). Very often the particular Ministry sends the report about the fulfilment of those measures to the government after the given time.

The SAO afterwards evaluates those measures. This evaluation happens for each audit. In the follow-up audits, the SAO assess the fulfilment of the adopted measures. Such evaluation is always part of the audit report (from the follow-up audit).

In the second step, the Committee on Budget Control assesses the remedial measures. The committee discusses the audit reports a few months after the meeting of the government, so it can assess progress.

\section{6) Audits on Parliament's request}

The government and both Chambers of the Parliament or their bodies may ask the SAO to conduct an audit. These are called qualified suggestions. The SAO Board can make a decision to place the suggestion into the annual audit plan, to use the suggestion in the current audit, to use the suggestion in the preparation of the annual audit plan in the future, or not to conduct such an audit.

In the years 2006 to 2015 the SAO received 26 suggestions: two from the government, four from the Senate and 20 from the Chamber of Deputies. The Committee on Budgetary Control suggested 13. Out of those 26 suggestions, 18 were used in the annual audit plan or will be used in the preparation of the Annual Audit Plan in the future. Within the same period the SAO conducted 362 audits.

\section{7) Work programme}

See also the previous answer. Most of the audits are planned within the SAO's own analytical activities. Qualified suggestions make only $5 \%$ of the audits in the annual audit plan.

\section{8) Level and frequency of contacts}

There were eight official meetings of the Committee on Budget Control in 2015. Besides the official meetings there are meetings of the member of the committee (the rapporteur) with the SAO member who conducted the particular audit. There are also many unofficial meetings of the SAO representatives with the members of the committee and other Parliament officials.

The SAO also invites the Committee representatives to its events, e.g. seminars and conferences.

\section{9) Good practice}

There is very good debate about all the SAO audit reports at the government official meetings. The SAO can help to enforce its recommendations at the executive level. In co-operation with the Parliamentary Committee, the SAO can check whether the recommendations and related measures were adopted and put into force.

\section{0) Perspective}

Unfortunately, in some cases the Parliament discusses the audit reports too late after they were published. The SAO representatives are attempting to improve this situation. 
11) Are there any other relevant features of the current relations between the SAI and Parliament that you would like to highlight, and how have they evolved over the past five years?

It would be useful for the audit reports to be discussed not only during the meetings of the Committee on Budget Control, but also during meetings of other relevant committees. 


\section{DENMARK}

National Audit Office

\section{1) Legal framework}

The Legal framework is mainly defined by Section 8.1. of the Auditor General Act

\section{(http://uk.rigsrevisionen.dk/legislation/the-auditor-general-act/ ):}

The Auditor General shall assist the Public Accounts Committee in its review of the state accounts. The Auditor General shall examine and report on matters which the Public Accounts Committee wishes to have clarified. The Public Accounts Committee and the Auditor General may request that joint meetings be held. At the Public Accounts Committee's request, the Auditor General shall participate in consultations with Folketing committees and the Public Accounts Committee.

\section{2) SAI reporting practices}

The reporting practice is defined by Section 17 of the Auditor General Act:

(1) The Auditor General shall examine the completeness of the state accounts and compare appropriation figures with accounting figures. The Auditor General presents a report to the Public Accounts Committee within a time limit to be agreed between the Public Accounts Committee and the Auditor General.

(2) The Auditor General shall present a report to the Public Accounts Committee on completion of such audit cases as the Auditor General wishes to highlight in view of their financial or principal importance.

(3) A case which is included in the Auditor General's report shall be presented to the minister concerned no later than four weeks before submitting the report. If the case concerns the counties mentioned in section $4(1)$ (i) the case shall also be presented to the county council. If a case concerns the limited liability companies mentioned to in section 4(2), first sentence, the case shall also be presented to the company's board of directors. No such presentation is required if previous correspondence concerning the case has taken place.

(4) The Auditor General shall present an annual report on his activities to the Public Accounts Committee at a time to be agreed upon with the Public Accounts Committee.

\section{Procedures for sending reports to Parliament}

Our SAl submit all reports to the Public Accounts Committee (PAC). An auditor who made the report presents it to PACs members. The PAC meets every month. 


\section{Number and type of reports}

\begin{tabular}{|c|c|c|c|c|c|c|c|}
\hline & $\begin{array}{l}\text { Financial } \\
\text { audit } \\
\text { reports }\end{array}$ & $\begin{array}{l}\text { Compliance } \\
\text { audit reports }\end{array}$ & $\begin{array}{c}\text { Performance audit } \\
\text { reports }\end{array}$ & $\begin{array}{l}\text { Other reports } \\
\text { or documents }\end{array}$ & $\begin{array}{l}\text { Annual } \\
\text { activity } \\
\text { reports }\end{array}$ & $\begin{array}{l}\text { Reports at } \\
\text { request of } \\
\text { Parliament }\end{array}$ & Remarks \\
\hline Number submitted & 1 & 15 & 11 & - & 1 & 5 & to PAC \\
\hline $\begin{array}{c}\text { Number discussed } \\
\text { by Parliament }\end{array}$ & 1 & 15 & 11 & - & 1 & 5 & by PAC \\
\hline $\begin{array}{l}\text { Submitted to } \\
\text { Speaker }\end{array}$ & Y & $Y$ & $Y$ & $Y$ & $Y$ & $Y$ & \\
\hline $\begin{array}{c}\text { Submitted to Chair } \\
\text { of dedicated } \\
\text { committee }\end{array}$ & $\mathrm{N}$ & $\mathrm{N}$ & $\mathrm{N}$ & $\mathrm{N}$ & $\mathrm{N}$ & $\mathrm{N}$ & It is possible \\
\hline $\begin{array}{l}\text { Copied to other } \\
\text { relevant } \\
\text { committees }\end{array}$ & $\mathrm{N}$ & $\mathrm{N}$ & $\mathrm{N}$ & $\mathrm{N}$ & $\mathrm{N}$ & $\mathrm{N}$ & It is possible \\
\hline $\begin{array}{l}\text { Briefings organised } \\
\text { for parliamentary } \\
\text { committee }\end{array}$ & $\mathrm{N}$ & $\mathrm{N}$ & $\mathrm{N}$ & $\mathrm{N}$ & $\mathrm{N}$ & $\mathrm{N}$ & It is possible \\
\hline $\begin{array}{l}\text { Summaries } \\
\text { submitted to } \\
\text { Parliament }\end{array}$ & $\mathrm{N}$ & $\mathrm{N}$ & $\mathrm{N}$ & $\mathrm{N}$ & $\mathrm{N}$ & $\mathrm{N}$ & \\
\hline
\end{tabular}

\section{3) Parliamentary procedures for SAI reports}

There are fixed procedures for handling SAI reports by the PAC. The rules are laid down in the Act of PAC, Auditor General Act and in parliaments rules of procedure.

The PAC is dedicated for handling SAI reports. The PAC is chaired by the member with longest seniority in the committee.

The committee does not appoint a rapporteur.

There are no hearings held to which the auditee or other appropriate persons are invited to provide clarification or further information;

The PAC can require additional information or clarification.

The debate on SAI reports is held in committee.

Where appropriate, other committees, apart from any dedicated committee, may also consider the reports of the SAl;

The SAI report is publish by the PAC with the committee's remarks.

There is a fixed procedure for discharge. Special report based on SAI memoranda is produced by the PAC. 


\section{Staffing}

The PAC (six politicians) is supported by three parliamentary staff (two academic level and one clerk). They are in charge of all the tasks listed above.

http://uk.rigsrevisionen.dk/the-public-accounts-committee/the-public-accounts-committee/

\section{Consideration of reports by Parliament}

Our SAI attends PACs meetings (Auditor General, Head of Secretariat and auditors who made the reports). They provide information and clarification on matters described in the reports.

\section{4) SAI reports}

The SAI reports three times a year.

\section{5) Follow-up on SAI reports}

The follow-up practices is defined by Section 18 of the Auditor General Act:

1) The Public Accounts Committee shall forward the reports mentioned in section 17(1) and (2) to the Folketing and the minister concerned with any comments. The report mentioned in section 17(4) shall be submitted to the Folketing.

(2) The minister shall present a response to the Public Accounts Committee on the measures and considerations which a report has given rise to within a time limit determined by the Public Accounts Committee upon recommendation by the Auditor General. A time limit of minimum two months and maximum four months shall be determined. For the report mentioned in section 17(1) the time limit is two months.

(3) The minister shall obtain a statement from the county council concerning the counties mentioned in section 4(1)(i). In respect of the limited liability companies mentioned in section 4(2), first sentence, the minister shall obtain a statement from the company's board of directors. In addition to the statement, the minister's comments on the county council's or the board of directors' statement shall be included in the response mentioned in subsection (2) to the Public Accounts Committee.

(4) The response and the statement from the county council or the board of directors of the limited liability company mentioned in subsection (3) shall at the same time be forwarded to the Auditor General, who shall submit his comments to the Public Accounts Committee within a month of receipt thereof.

(5) The ministers' responses and the Auditor General's comments shall form part of the Public Accounts Committee's final report to the Folketing. If the Public Accounts Committee considers it appropriate the statements mentioned in subsection (3) may also be included in the final report.

\section{6) Audits on Parliament's request}

Only the PAC can request the SAI to make a specific audit. About $20 \%$ of our SAI reports are made as the result of a request from the PAC. 


\section{7) Work programme}

The SAI informs the PAC of its annual Work programme of audits. There is no consultation on the plan, but the PAC may make suggestions.

\section{8) Level and frequency of contacts}

There is a regular contact (day to day) between our SAls Head of Secretariat and the Head of Secretariat of the PAC.

The Auditor General meets the PAC monthly.

\section{9) Good practice}

Our follow-up procedure follows Good practice.

The SAI reports the results of the annual audit and major studies to the PAC. Subsequently, the SAI and the PAC follow up the results to ascertain whether the ministries act on our recommendations. This follow-up procedure is unique in an international perspective, and contributes to ensuring that the audits are effective.

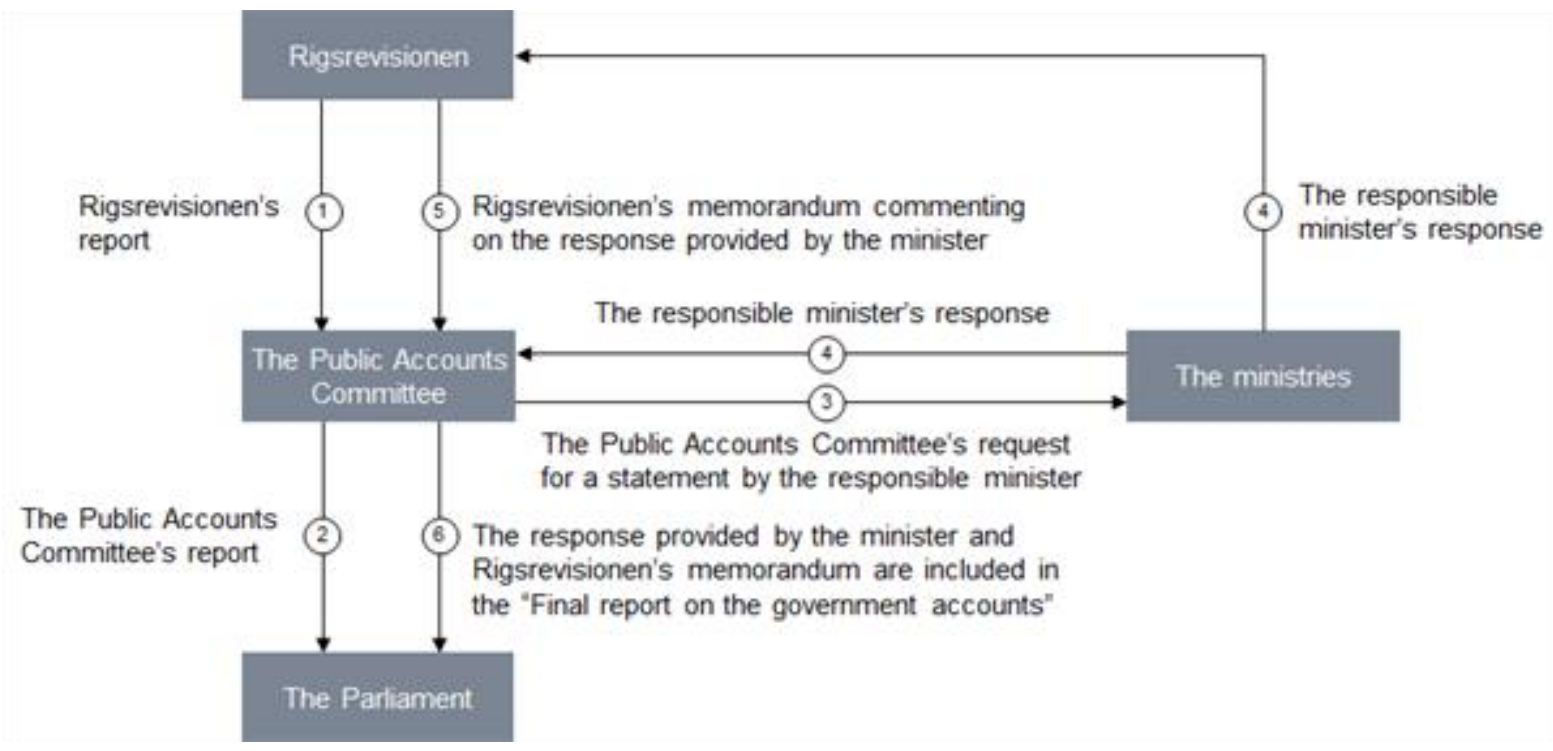

Once the SAI (Rigsrevisionen) has submitted its report to the PAC, the committee members comment on the report, which is subsequently forwarded to parliament.

At the same time the PAC ask the responsible minister to submit his/her comments to the audit findings.

Within two to four months, as determined by the PAC, the minister shall inform Rigsrevisionen and the Committee of the measures that the department will implement to meet the recommendations.

On the basis of this statement, Rigsrevisionen submits a follow-up memorandum to the PAC, recommending either that the case be closed, since all issues have been appropriately addressed, or that there are still outstanding matters that Rigsrevisionen intends to follow up. 
Ministerial statements and follow-up memoranda prepared by Rigsrevisionen are made public in the Final Report on the Government Accounts, which is submitted to parliament once a year by the PAC. The report on the government accounts forms the basis for the parliament's approval of the government's accounts for the fiscal year.

\section{0) Perspective}

Some SAI reports have been sent by the PAC to the other committees. Some of the other committees requested a presentation of an SAI report. It is to believe that the interest of other committees in SAI reports will be growing in the future. 


\section{ESTONIA}

National Audit Office

\section{1) Legal framework}

The independence of the National Audit Office of Estonia (NAOE) is secured by the Constitution and the National Audit Office Act.

Under the National Audit Office Act the NAOE decides independently on the programme of audits, including the time and nature. No one can order the National Audit Office to perform mandatory audit functions. Members of the Parliament can ask questions from the Auditor General (AG) about subjects that are of interest to them, or that are on the agenda of the Parliament and fall in the area of activity of the National Audit Office.

The Act sets down that the work of the NAOE is based on the work schedule approved by the AG. The work schedule is available on NAOE website, and the AG presents it to the State Budget Control Select Committee of the Parliament.

The activities of the NAOE are annually audited by an auditor appointed by the Parliament. The NAOE submits its audited annual report to the Parliament.

The Constitution also stipulates that the AG will present to the Parliament an overview on the use and preservation of State assets. Each autumn, the AG supplements this analytical report summarising a year of work by giving a speech before the Parliament, and replying to the questions of members of the Parliament.

\section{2) SAI reporting practices}

Under the National Audit Office Act, the Parliament's State Budget Control Select Committee serves as a link between the NAOE and the Parliament.

The AG submits all audit results (financial, compliance and performance audit reports) to the State Budget Control Select Committee (addressed to the Head of Select Committee). The NAOE annual report and an overview on the use and preservation of state assets are submitted to the Speaker of the Parliament. Reports are sent and discussed separately. A representative of the NAOE and an auditee are invited to participate in the discussion of audit results in the select committee. Deadlines for sending reports to the select committee are not regulated.

Performance audit reports are often sent also to other committees of Parliament where they are discussed similarly. In some cases committees have had joint meetings for discussing some audit reports of the NAOE.

\section{Procedures for sending reports to Parliament}

Reports are sent to the State Budget Control Select Committee in electronic format with digital signatures.

The NAOE holds closed briefings of audit reports to the members of the State Budget Control Select Committee, usually once a week. 
After briefing the audit report is discussed at public hearing of the select committee. These hearings are accessible online. Representatives of the NAOE summarise the audit results and reply to the questions of members of the select committee. Subsequently the representatives of auditee present their opinion and explanations. At the end of the meeting the Head of the Select Committee summarises the discussion and information is noted. In some cases it is decided to conduct another meeting on the same subject after half a year, or send a notice letter to the responsible institution.

\section{Number and type of reports}

\begin{tabular}{|c|c|c|c|c|c|c|c|}
\hline & $\begin{array}{l}\text { Financial } \\
\text { audit } \\
\text { reports }\end{array}$ & $\begin{array}{l}\text { Compliance } \\
\text { audit reports }\end{array}$ & $\begin{array}{c}\text { Performance audit } \\
\text { reports }\end{array}$ & $\begin{array}{l}\text { Other reports } \\
\text { or documents }\end{array}$ & $\begin{array}{l}\text { Annual } \\
\text { activity } \\
\text { reports }\end{array}$ & $\begin{array}{l}\text { Reports at } \\
\text { request of } \\
\text { Parliament }\end{array}$ & Remarks \\
\hline Number submitted & 18 & 6 & 6 & 2 & 2 & - & \\
\hline $\begin{array}{c}\text { Number discussed } \\
\text { by Parliament }\end{array}$ & 2 & $\begin{array}{c}5 \text { (sometimes } \\
\text { more than once) }\end{array}$ & $\begin{array}{c}7 \text { (sometimes } \\
\text { more than once) }\end{array}$ & & & & \\
\hline $\begin{array}{l}\text { Submitted to } \\
\text { Speaker }\end{array}$ & - & - & - & & 2 & - & $\begin{array}{l}\text { There were } \\
\text { also two } \\
\text { information } \\
\text { requests by } \\
\text { MPs, to } \\
\text { which the } \\
\text { AG } \\
\text { responded }\end{array}$ \\
\hline $\begin{array}{l}\text { Submitted to Chair } \\
\text { of dedicated } \\
\text { committee }\end{array}$ & 18 & 6 & 7 & 2 & 2 & - & \\
\hline $\begin{array}{l}\text { Copied to other } \\
\text { relevant } \\
\text { committees }\end{array}$ & 1 & 3 & 6 & & 1 & - & \\
\hline $\begin{array}{l}\text { Briefings organised } \\
\text { for Parliamentary } \\
\text { committee }\end{array}$ & 2 & 5 & 13 & 2 & 2 & - & \\
\hline $\begin{array}{l}\text { Summaries } \\
\text { submitted to } \\
\text { Parliament }\end{array}$ & 18 & 6 & 6 & 2 & 2 & - & \\
\hline
\end{tabular}

\section{3) Parliamentary procedures for SAI reports}

According to the National Audit Office Act the main contact point for the NAOE in the Parliament is the State Budget Control Select Committee, which monitors that the State budget funds and State assets are used economically, efficiently, effectively and lawfully. 
The Rules of Procedure and Internal Rules Act of Parliament provide general framework for organising the work of the committees of the Parliament without specifically mentioning the State Budget Control Select Committee.

The State Budget Control Select Committee is each time formed as a result of political negotiations, also considering tradition. All factions are represented by one or more members. Since 2015 there have been 6 factions, each represented by one member. The previous committee consisted of eight members from four factions.

The Head of the committee has traditionally been the representative of major opposition faction, while deputy head comes from the coalition.

The select committee does not appoint rapporteurs for audit reports. Reports are presented by representatives of the NAOE.

The select committee holds public hearings to which auditees or other appropriate persons are invited to provide clarification or further information. The debate on NAOE reports is held in the select committee, sometimes also in special committees and made public online.

In the end of the meeting the Head of the Select Committee summarises the discussion and information is noted. Usually the select committee does not prepare a special document following the discussion. Sometimes a press-release is issued. In some cases it has been decided to conduct another meeting on the same subject after half a year, or send a notice letter to the responsible institution. There have been 2 exceptions since the establishment of the committee in 2004 when the committee produced its own report on the report of the NAOE.

Once a year the AG presents to the Parliament (plenary) an overview on the use and preservation of State assets. This is the only report of the NAOE, which is discussed at plenary.

The NAOE has to complete the audit of the annual accounts of the consolidated annual report of the State, and the verification of the lawfulness of the transactions by 31 August and submit to the State Budget Control Select Committee. All NAOE reports are first submitted to the select committee. The report is also sent the Ministry of Finance.

The Ministry of Finance must submit the consolidated annual report of the State, together with a draft resolution about the distribution of the State unconsolidated cash flow surplus. It must also submit the audit report of the NAOE published on the audit of the annual accounts of the consolidated annual report of the State, and the verification of the lawfulness of the transactions, to the Government of the Republic. These documents must be approved within seven working days of the receipt of the report from the NAOE. The reports are published on the website immediately after submission to the Government of the Republic. The Government of the Republic then submits the approved consolidated annual report of the State to the Parliament for approval. The audit report of the NAOE must be added to the consolidated annual report of the State. Before submitting them to the plenary of the Parliament, the reports are discussed in the State Budget Control Select Committee and Finance Committee.

When the report on the implementation of the State budget is debated in the Parliament, the AG makes a speech before the plenary of the Parliament presenting an annual overview on the use and preservation of State assets. Before approval of the report on the implementation of the State budget the members of the Parliament may ask questions regarding both annual reports of the NAOE. 


\section{Staffing}

The work of State Budget Control Select Committee is coordinated by two officials who are responsible for technical organisation of meetings. They invite representatives from audited institutions and also gather additional information, if needed.

\section{SAl involvement in consideration of reports by Parliament}

The NAOE is involved in the preparation of hearings of its reports by advising whom to invite to the hearings and what additional materials the members of the select committee might want to read before the hearing.

Members of the select committee are briefed by NAOE representatives audit results. Briefings are closed meetings.

The NAOE delegation includes the Director of Audit who signed the report, the Audit Manager and auditors involved in the auditing.

\section{4) SAI reports}

The NAOE focuses on generic/systemic problems in audits and makes recommendations for improvement both in audits and in its communications to Parliament.

The NAOE is consistent in emphasising the relevance of internal control systems and gives opinion on the internal control systems of ministries in the annual review of State consolidated accounts.

Audits contain clear opinions and recommendations to the responsible stakeholders.

\section{5) Follow-up on SAI reports}

The NAOE follows the implementation of recommendations routinely. Audit departments keep track of the recommendations and summarise developments that have annually taken place. In addition to that a summary of audit results for the last 10 years (since its establishment) was recently compiled at the Local Governments Audit Department. The NAOE plans to make such analyses also at other departments. The NAOE does not specifically report on the implementation of recommendations. Input about the implementation percentage of recommendations has been required in the budgeting process. However, the direct or regular use and impact of this information has been difficult to assess.

The select committee does not follow actively the implementation of recommendations of the NAOE. In some cases follow-up meetings are organised half a year after the hearing. Four audits were discussed at additional meetings in 2015. One of those audits was discussed at four additional meetings where experts and members from other committees of parliaments were also invited.

\section{6) Audits on Parliament's request}

The National Audit Office Act or any other piece of legislation does not give a mandate to the Parliament for requiring audit from the NAOE. The Parliament can suggest topics, but the NAOE is independent in deciding whether to undertake such audit.

Members of the Parliament can submit written questions to leading State officials, including the AG about subjects that are of interest to them or that are on the agenda of the Parliament and fall in the 
area of activity of the official. It is compulsory to orally answer to interpellations within 20 Parliamentary working days ( 3 weeks a month and 4 days a week) in front of the plenary of the Parliament. Written questions must be answered in writing within 10 parliamentary working days.

\section{7) Work programme}

The State Budget Control Select Committee annually collects ideas for suggesting audits for the NAOE. Usually there are 20-25 proposals, which are presented to the NAOE. The NAOE analyses the proposals and responds to the select committee by informing, which proposals will be included in work schedule, which have been audited and which will not be audited, providing reasons for the decision.

According to the National Audit Office Act the Parliament has no mandate to require audits from the NAOE.

\section{8) Level and frequency of contacts}

The AG meets the head of the State Budget Control Select Committee, usually 4-5 times a year. The AG participates personally in the meeting when he presents the new work schedule to the Committee. Also he introduces the annual overview on the use and preservation of State assets to the committee members before making his speech in front of the plenary of the Parliament.

The AG participates occasionally in the Committee hearings, if he would like to emphasise the importance of some audit reports.

The AG meets the Speaker of the Parliament at least once a year, when he hands over the annual overview on the use and preservation of State assets.

Everyday contacts with the select committee are handled by the Communication manager of the NAOE.

\section{0) Perspective}

The main problem for the NAOE is that the discussions of audit results do not have desired impacts, and often the discussion stops with the hearing. The members of the Committee do not take the initiative to ask for improvement from the Government. The Committee's working principle is consensus and therefore, it is not frequent that the Committee decides to continue working with audit results.

11) Are there any other relevant features of the current relations between the SAI and Parliament that you would like to highlight, and how have they evolved over the past five years?

The case of the NAOE has shown that maybe working with a select committee is not the most efficient method for ensuring the implementation of recommendations. In some cases quicker results can be achieved when problems are discussed with officials at executive level. 


\section{THE EUROPEAN COURT OF AUDITORS}

\section{1) Legal framework}

As an EU institution, established by Treaty, the European Court of Auditors (ECA) performs its audits within an inter-institutional framework laid down mainly by the Treaty on the Functioning of the European Union (TFEU) and the Financial Regulation for the general budget of the EU.

The Treaty stipulates that the ECA is to assist the European Parliament (EP) and the Council of the European Union (Council) in exercising their powers of control over the implementation of the budget and that it may, at any time, submit observations on specific questions and deliver opinions at the request of one of the EU institutions.

A key element of the assistance we provide to the EP and the Council is within the procedure of discharge of the Commission and other institutions on their implementation of the EU budget (Article 319 TFEU). This process takes as its main basis our annual report, and in particular the results of the statement of assurance (article 287 TFEU).

We take into account the needs of our stakeholders when establishing our Work programme, to help ensure our audits are as relevant and useful as possible. The EP and Council are both key stakeholders, and we consider requests or suggestions made by them along with our other priorities when deciding on audit tasks.

\section{2) SAI reporting practices}

The results of our audit work are published on our website and made available to the EP and other stakeholders. We have three main outputs:

- annual reports mainly containing the results of our financial and compliance audit work on the EU budget and the European Development Funds. In addition we publish separate specific annual reports on the EU's agencies, decentralised bodies and joint undertakings ${ }^{32}$

- special reports which we publish throughout the year, presenting the results of our selected audits of specific budgetary areas or management topics. These are mainly performance audits;

- opinions on new or updated legislation with an impact on financial management and other review-based outputs (such as landscape reviews) either at the request of another institution or at our own initiative.

We also publish and provide to the EP our:

- annual activity report providing an overview of our key results and achievements during the year; and

- annual Work programme setting out our priorities and tasks for the year.

Our annual reports (including the institutions' replies) are published in the EU's Official Journal. We provide a copy to the President of the EP, the chair of the Committee on Budgetary Control, and the 'rapporteur' for the discharge. We also send a copy of our annual reports to each MEP individually.

32 Article 287 of the Treaty on the Functioning of the European Union 
Regarding special reports, we send them to the President of the EP, to all the MEPs in the Committee on Budgetary Control (CONT) and to the other EP specialised committees competent for the subject of the audit. We select the subjects for our selected audits during our annual work programming procedure. In doing so we take into account stakeholder views - including those of the EP - to help ensure the resulting reports are as relevant and useful as possible.

In terms of timetable the Financial Regulation lays down that the ECA shall transmit to the authorities responsible for giving the discharge (EP and Council), by 15 November (year $n+1)$ at the latest, its annual report accompanied by the replies of the Institutions. The EP, on a recommendation from the Council, shall, before 15 May of year $n+2$ give the discharge to the Commission in respect of the implementation of the budget for year $n$, which is the financial year under consideration.

For special reports, there is no timetable provision for their publication in the Financial Regulation (other than in general they should be completed within 13 months ${ }^{33}$ ). As such we publish them throughout the year, aiming to ensure a steady flow to avoid over-concentration.

As part of a paperless policy we introduced in 2016, we no longer send our reports to stakeholders in printed format, but to targeted EP Committees, secretariats and other key stakeholders on the day of the publication via email notices.

All ECA reports are discussed at CONT. Moreover, ECA Members are invited to present their special reports and participate in the debate at specialised EP committees that show an interest in the topic.

In 2015 we published 25 special reports on various themes and topics of particular interest. They were generally performance audits. During 2015, we presented to the European Parliament 26 special reports (2014 and 2015 special reports), our annual reports on the implementation of the EU budget for the 2014 financial year and on the European Development Funds. In addition, we delivered 52 specific annual reports $^{34}$, our 2014 activity report and we presented to CONT two landscape reviews on EU accountability and risks to financial management.

\section{3) Parliamentary procedures for SAI Report}

According to the Rule 125 of the EP's Rules of procedure, in the context of the discharge procedure or of Parliament's activities in the sphere of budgetary control, the President of the Court of Auditors may be invited to take the floor in order to present the comments contained in the annual report, special reports or opinions, or in order to explain the Work programme. Parliament may decide to hold a separate debate on any questions raised in such statements with the participation of the European Commission and Council, in particular when irregularities in financial management have been reported.

The CONT committee within the EP is our key partner. Like all the other EP committees, CONT elects a chair and up to four vice-chairs among its full members. Generally, the political structure (and composition) of the EP committees reflects that of the plenary assembly.

Regarding our special reports, the CONT, through its political group coordinators, appoints a Reporting Member for each report. The Reporting Member's task is to prepare a working document which will form

\footnotetext{
33 Article 163(1) of Regulation (EU, EURATOM) 2015/1929 of the European Parliament and of the Council of 28 October 2015 amending Regulation (EU, Euratom) No 966/2012 on the financial rules applicable to the general budget of the Union.

34 The full text of all our reports is available in $23 \mathrm{EU}$ languages on our website ( $\underline{\mathrm{http}: / / \text { eca.europa.eu) }}$
} 
the basis of deliberations in committee and is frequently used for the preparation of the annual discharge process. Plenary debates and legislative votes are always preceded by the committee stage and are based on committee reports.

During the committee meetings, there is an exchange of views on the ECA special report and the working document, in the presence of the ECA Member responsible and a representative of the Commission. The committee considers all ECA special reports very carefully because they form an integral part of the discharge procedure. Moreover, the EP adopts a separate resolution on the special reports published during the year of the specific discharge. It is above all in the context of the annual procedure for the discharge that our annual and special report observations provide the basis for the decision taken by the EP for its discharge resolution.

Moreover, within the discharge procedure on the implementation of the budget, the CONT debates follow the structure of our annual report chapters. This process takes place over several CONT meetings, and involves the hearing of Commissioners responsible for the respective budgetary areas. The ECA Member responsible for the specific chapter is also present. The Commissioners are invited to provide the EP with a detailed account on how the budget in their respective area has been spent. The CONT votes on the discharge of the budget by the end of March and the final vote takes place in plenary in April.

The European institutions are required to address the observations contained in the EP's resolution and take steps to safeguard the European taxpayers' money by improving the quality of management systems and adopting the necessary measures to protect the EU finances. At the request of the EP or the Council, the institutions are required to report on the measures taken in light of these observations and comments.

\section{Staffing}

Each EP Committee is supported in its tasks by a committee secretariat, the EP's policy departments (providing parliamentary research and background briefings) and by its own political group secretariats. The committee secretariat facilitates contacts with other institutions and interested parties, makes the necessary arrangements to ensure a smooth committee reading of the texts, advises the MEPs on all procedural questions and provides assistance in drafting reports and resolutions.

\section{SAI involvement in consideration of reports by Parliament}

Regarding special reports, our Member for Institutional Relations and his supporting team keep the EP Committees regularly informed of our planned special reports, and their expected publication date. This helps the committees to plan their related activities. Once the reports are completed and approved ('adopted') by the ECA, the reporting Member contacts the CONT Reporting Member and provides $\mathrm{him} /$ her with an advance and confidential copy of the special report. Prior to the CONT meeting, communications/meetings often take place in order to give the CONT Reporting Member additional insights into the findings and recommendations of the special report, providing useful information in view of the Committee debate. At the invitation of CONT, the ECA Reporting Member presents the special report to the committee, replies to the questions of the MEPs and takes part in the discussion. In the 8th parliamentary term (2014-2019), CONT committee has established a new arrangement whereby they invite the relevant specialised committee to attend the CONT meeting. Joint meetings are sometimes organised. In addition, some of our special reports are - after the presentation in the CONT - presented and discussed in the other relevant specialised committees which have a specific interest in the topic. 
Regarding the annual report, we forward it to the EU institutions and publish it in the Official Journal, together with the institutions' replies. The ECA President presents the annual reports to the CONT committee, as well as to the EP plenary session and takes part in the discharge debate. The discussion of the different chapters of the annual report, under the discharge procedure, takes place during several CONT meetings, and involves the hearing of Commissioners for each area of the budget, in the presence of the ECA Members responsible.

\section{4) SAI reports}

Our special reports set out findings, conclusions and recommendations on the audited subject. This can include both individual transactions as well as control systems.

Our annual report is divided into chapters addressing the different areas of the EU budget. Each chapter provides conclusions and recommendations on the area in question. In addition to the assessment of the legality and regularity of the underlying transactions, observations on the performance of the spending are also provided in some areas. Moreover, the results of our examination of selected control systems are also presented in the income and spending chapters, together with recommendations for their improvement.

\section{5) Follow-up on SAI reports}

Since 2012, the ECA has carried out reviews of the Commission's follow-up of its recommendations made in previous special reports. We have published three consolidated reports on follow-up (SR 19/2012, SR 19/2013 and SR 2/2016) and a summary form of the observations from the 2013 follow-up exercise within the 2013 annual report. The follow-up to previous annual report recommendations is made and reported on each year in the relevant chapters.

The special reports on the follow-up form an integral part of the discharge procedure. In accordance with Article 166 of the Financial Regulation, the Commission and the other institutions shall take all appropriate steps to act on the observations accompanying the EP's discharge decision and on the comments accompanying the recommendation for discharge adopted by the Council.

\section{6) Audits on Parliament's request}

According to the article 287 TFEU, the Court of Auditors shall provide the EP and the Council with a statement of assurance on the reliability of the accounts and the legality and the regularity of the transactions underlying them. It shall draw up an annual report after the close of each financial year.

For the special reports, the Treaty states that the ECA may also at any time submit observations, particularly in the form of special reports, on specific questions. There is no legal provision that enables Parliament to request audits on specific subjects, although we take into account their suggestions and priorities when establishing our Work programme. See also replies to questions 7 and 9 below.

\section{7) Work programme}

We obtain feedback from the EP on their suggestions and priorities from a variety of sources such as: the discharge documents, records of committee meetings, presentation of our Work programme ${ }^{35}$,

35 Presentation of the 2016 Work programme to the Committee on Budgetary Control of the EP, Brussels, 11 January 2016, http://www.eca.europa.eu/Lists/ECADocuments/Speech WP2016/speech-WP2016-EN.pdf 
consultations with the Conference of Committee Chairs ${ }^{36}$, contact with individual MEPs etc. We take all these suggestions into account alongside our other priorities when deciding on our Work programme, and in particular the topics for selected audits.

\section{8) Level and frequency of contacts}

The President and ECA Members maintain regular contacts with the committees of the EP, in particular with CONT. On a yearly basis, the ECA President participates in CONT meetings in order to present our annual Work programme and annual reports, as well as in EP plenary sessions to present the annual reports and take part in the discharge debate. The ECA President has also regular contacts with the Conference of Committee Chairs as described above.

Moreover, the cooperation between the CONT and other committee members and the ECA Member responsible for institutional relations has been developed, deepened and increased since his appointment in April 2014, helping identify opportunities for presenting and making greater use of our work, and therefore increasing its impact.

Within the Directorate of the Presidency, a dedicated institutional relations team has been established to coordinate, consolidate and strengthen relations with CONT and other parliamentary committees. This team facilitates daily contacts with the CONT secretariat and increasingly frequent contacts with other committee secretariats. The team coordinates and attends all CONT and other relevant EP meetings and provides rapid feedback to the ECA Members and management.

On a yearly basis, CONT MEPs and staff from the CONT secretariat hold a meeting with ECA Members and support staff to discuss issues of common interest aiming at improving cooperation.

\section{9) Good practice}

Examples include:

- the appointment of an ECA Member with responsibility for institutional relations, which has contributed to enhancing our relations with other EU institutions at a strategic level, and identifying opportunities for increasing the impact of our audit work;

- encouraging EP's committees to suggest priority areas and topics for us to consider when establishing our Work programme;

- the cooperation of the ECA with other EP bodies ( Directorate-General Internal Policies and European Parliamentary Research Service), that brings to a broader audience and better usage of ECA's special reports. Moreover it aims to create an information exchange network and provide valuable input for both parties regarding policy and risk assessment, performance appraisal, added value and impact assessment; and

- establishing a powerful database and associated system for managing (sending and recording) our communication with stakeholders, allowing us to target the sending of our audit reports and information to individuals and institutions based on their specific interests.

The Conference of Committee Chairs (CCC) is the political body that coordinates the work of the committees and ensures the smooth cooperation between them. It consists of the Chairs of all standing and special committees and meets monthly 


\section{0) Perspective}

For the last three years, our institution has invested much time and effort into increasing our cooperation with, and presence in, the EP. This is the result of a comprehensive communications and stakeholders relations strategy we prepared in 2013. In the future we will focus on further increasing our presence in specialised committees, deepening our awareness of the EP's needs and improving our responsiveness to Parliament's requests. We will do so whilst safeguarding our independence as the external audit institution of the EU. 
FRANCE

Court of Audit

\section{1) Legal framework}

The Legal framework is mainly defined by:

- Section 47-2 of the French Constitution, passed in July 2008 : "The Cour des Comptes shall assist Parliament in monitoring Government action. It shall assist Parliament and the Government in monitoring the implementation of Finance Acts and Social Security Financing Acts, as well in assessing public policies. By means of its public reports, it shall contribute to informing citizens."

- The Institutional Act relating to Finance Acts passed in August 2001, especially its section 58 setting out a list of reports made by the Cour des comptes for the Parliament, on request or on an annual basis.

- The Code des Juridictions Financières (Code of Financial Jurisdiction) that defines relationships between the Houses and the Cour des comptes.

\section{2) SAI reporting practices}

Two types of reports are sent to the Parliament : regular report and audit on request.

\section{Regular reports with deadlines}

The Cour des comptes delivers to the Parliament :

- its annual report (to the President of the House), also delivered to the President of the Republic;

- report on the implementation of the Social Security Finance Act (President of both houses);

- annual report on local governments finances (President of both houses);

- annual audit on the financial statement of the States and those of Social security (Presidents of Budget and Social Affairs standing committees);

- report on the fiscal balance and enforcement of finance laws (Presidents of Budget Standing committees);

- report on the situation and prospects of public finance (Presidents of Budget Standing committees).

The delivery calendar is determined by laws and institutional acts, and is designed to give MPs information, tools and analysis for the consideration of financial bills.

The Cour thematic public reports (more than 20 a year) and observations to the Government on any public policies are also sent to the Parliament.

\section{Reports on request}

The Institutional Act relating to the Finance Acts of August 2001 allows the Budget Standing Committees of both houses (i.e.: Assemblée nationale and Sénat) to ask for reports on a particular subject. The Cour des comptes has nine months to send the report. This deadline can be postponed in agreement with the standing committee. The Cour des comptes sends five reports for each House per year. 
This possibility also exists for the Social Affairs Standing Committee, used about once a year per House.

Reports can deal with any subject related to public policies. They are always addressed to the President of the standing committee at the origin of the request.

\section{Procedures for sending reports to Parliament}

Each audit made on request is submitted by the Cour des comptes during a public hearing in front of the standing committee.

The annual report is submitted in the hemicycle by the First President.

\section{Number and type of reports}

\begin{tabular}{|c|c|c|c|c|c|c|c|}
\hline & $\begin{array}{l}\text { Financial } \\
\text { audit } \\
\text { reports }\end{array}$ & $\begin{array}{l}\text { Compliance } \\
\text { audit reports }\end{array}$ & $\begin{array}{c}\text { Performance audit } \\
\text { reports }\end{array}$ & $\begin{array}{l}\text { Other reports } \\
\text { or documents }\end{array}$ & $\begin{array}{l}\text { Annual } \\
\text { activity } \\
\text { reports }\end{array}$ & $\begin{array}{l}\text { Reports at } \\
\text { request of } \\
\text { Parliament }\end{array}$ & Remarks \\
\hline Number submitted & 1 & 2 & 4 & & 1 & 15 & \\
\hline $\begin{array}{c}\text { Number discussed } \\
\text { by Parliament }\end{array}$ & 1 & 2 & 4 & & 1 & 15 & \\
\hline $\begin{array}{c}\text { Submitted to } \\
\text { Speaker }\end{array}$ & $\mathrm{Y}$ & $Y$ & $Y$ & & $\mathrm{Y}$ & $\mathrm{N}$ & \\
\hline $\begin{array}{l}\text { Submitted to Chair } \\
\text { of dedicated } \\
\text { committee }\end{array}$ & $\mathrm{Y}$ & $Y$ & $Y$ & & $\mathrm{Y}$ & $\mathrm{Y}$ & \\
\hline $\begin{array}{l}\text { Copied to other } \\
\text { relevant } \\
\text { committees }\end{array}$ & $Y$ & $Y$ & $Y$ & & $\mathrm{Y}$ & $\mathrm{N}$ & \\
\hline $\begin{array}{l}\text { Briefings organised } \\
\text { for Parliamentary } \\
\text { committee }\end{array}$ & $Y$ & $Y$ & $Y$ & & $\mathrm{Y}$ & $Y$ & \\
\hline $\begin{array}{l}\text { Summaries } \\
\text { submitted to } \\
\text { Parliament }\end{array}$ & $\mathrm{Y}$ & $Y$ & $\mathrm{Y}$ & & $\mathrm{Y}$ & $Y$ & \\
\hline
\end{tabular}

\section{3) Parliamentary procedures for SAI reports}

Reports are negotiated between the Cour and the standing committee, especially for setting the subject and the timetable.

Budget Standing Committee and Financial Affairs Standing Committee make requests for audits. The President of the Budget Standing Committee has been a member of the opposition since 2007 in National assembly, and 2012 in the Senate. This principle is based on tradition. 
A rapporteur is always appointed for each report.

A preliminary hearing takes place between the Rapporteur and staff in charge of the report. A public hearing for the presentation takes place when the report is sent to the Committee.

There has been no occurrence of the committee using independent external experts in examining reports.

The debate on SAI reports is held in committee, and sometimes in plenary, at least once a year for the annual report.

Other committees may also consider the reports of the SAI, even if the field of the report is often very specific.

The committee authorises the publication of the report by a vote at the end of the hearing. There is no formal discharge procedure.

\section{Staffing}

There are about 15 staff for each Budget Committee, and 10 for each Social Affairs Committee. They are in charge of all the tasks listed below. Their level is the same as SAI staffers.

\section{SAI involvement in consideration of reports by Parliament}

The level of the Cour representation for the hearing is very high (President or First President). A speech is made, and questions are asked by MPs.

There is a formal presentation by the SAI for the committee, and once a year (annual report) for the complete assembly, but the Parliament is free to ask any question based on the report. The role of the SAI is to provide the report, and to answer on issues raised by MPs. The SAI does not prepare questions for hearings of the government, even when based on its report.

\section{4) SAI reports}

The SAI focuses on generic/systemic problems and recommendations in its communications to Parliament.

The set up and functioning of internal control systems is not a subject that is highlighted in SAl reports, as internal control is generally not a matter of interest for MPs.

All audit reports contain clear conclusions and audit opinions.

\section{5) Follow-up on SAI reports}

This question does not only deal with Parliament.

The Cour by itself makes a very precise follow-up of recommendations issued in any report, including reports for the Parliament. The annual public report presents an analysis of the result. This follow-up is regularly used as input by MPs, especially during the budget debate. 


\section{6) Audits on Parliament's request}

The Institutional Act relating to the Finance Acts in August 2001 allows the Budget Standing Committees of both Houses (i.e. Assemblée nationale and Sénat) to ask for reports on a particular subject. The Cour des comptes has 9 months to send the report. This deadline can be postponed by agreement with the standing committee. The Cour des comptes sends five reports for each House per year.

This possibility also exists for the Social Affairs Standing Committee, used about once a year per House.

\section{7) Work programme}

The Constitutional Court does not authorise the dispatch to the Parliament of the Cour Work programme, as the Cour is a jurisdiction. As a consequence, the programme of the Cour is made under no pressure or suggestions of the Parliament.

\section{8) Level and frequency of contacts}

The frequency of contacts is quite impossible to describe, especially when it is informal. There are between 40 and 50 hearings, public or not, each year on request of the Parliament. One person is in charge of relationships between the Cour and the Parliament, but not as a full time job.

\section{9) Good practice}

The impact of the Cour reports relies only on the MPs' will to implement recommendations issued by the Cour. As a consequence, a specific task is to make sure that reports are written clearly, and that recommendations can be applied by the Parliament. Staff are aware of this, as the follow-up of recommendation is a part of their job.

\section{0) Perspective}

Relationships are based on quite recent laws that took time to be understood by both Cour and Parliament. A former first president of the Cour, who happened to be former President of the Lower House, used to say that the Cour should be "just between Parliament and Government."

So relationships are excellent and cannot evolve in the short-term, as the status of jurisdiction of the Cour does not authorise any further rapprochement. 


\section{THE FORMER YUGOSLAV REPUBLIC OF MACEDONIA}

State Audit Office

\section{1) Legal framework}

The communication with Parliament is regulated in the State Audit Law (SAL), meaning that the State Audit Office (SAO) annual report and all final audit reports are sent to the Parliament. SAO's work plan is submitted to Parliament for consideration. In the SAO Guidelines for proposing audits for the annual programme (an internal SAO act), the SAO may include audit proposals requested by the Parliament.

\section{2) SAI reporting practices}

The SAO submits to the Parliament all final audit reports, no matter their type, (regularity or performance audit). The reports are addressed to the President of the Parliament of the Republic of Macedonia.

Article 33 (of SAL):

1. The State Audit Office shall prepare an annual report on conducted audits and operation of the State Audit Office.

2. The State Audit Office shall submit the report from paragraph (1) of this Article for review to the Parliament of the Republic of Macedonia no later than 30 June for the previous year.

3. The Parliament of the Republic of Macedonia shall review the report from paragraph (1) of this Article and adopt conclusions upon it.

4. Final audit reports referred to in Article 30 paragraph (3) of this Law shall be submitted to the Parliament of the Republic of Macedonia.

\section{Procedures for sending reports to Parliament}

The SAO submits to the Parliament all final audit reports. A copy of the SAO annual report is sent to each MP. The Auditor General (AG) attends the session of the Parliamentary Budget and Financing Committee when the annual report is reviewed and provides an explanation of it. The same procedure goes for the plenary session of the Parliament when the annual report is reviewed and conclusions are adopted. 
Number and type of reports

\begin{tabular}{|c|c|c|c|c|c|c|c|}
\hline & $\begin{array}{l}\text { Financial } \\
\text { audit } \\
\text { reports }\end{array}$ & $\begin{array}{l}\text { Compliance } \\
\text { audit reports }\end{array}$ & $\begin{array}{c}\text { Performance audit } \\
\text { reports }\end{array}$ & $\begin{array}{l}\text { Other reports } \\
\text { or documents }\end{array}$ & $\begin{array}{l}\text { Annual } \\
\text { activity } \\
\text { reports }\end{array}$ & $\begin{array}{l}\text { Reports at } \\
\text { request of } \\
\text { Parliament }\end{array}$ & Remarks \\
\hline Number submitted & $43^{*}$ & $43^{*}$ & $18+13^{*}$ & 1 & 1 & & \\
\hline $\begin{array}{c}\text { Number discussed } \\
\text { by Parliament }\end{array}$ & & & & & 1 & & \\
\hline $\begin{array}{c}\text { Submitted to } \\
\text { Speaker }\end{array}$ & $\bar{Y}$ & $Y$ & $\bar{Y}$ & $Y$ & $\bar{Y}$ & & \\
\hline $\begin{array}{l}\text { Submitted to Chair } \\
\text { of dedicated } \\
\text { committee }\end{array}$ & $\mathrm{N}$ & $\mathrm{N}$ & $\mathrm{N}$ & $\mathrm{N}$ & $\mathrm{N}$ & & \\
\hline $\begin{array}{l}\text { Copied to other } \\
\text { relevant } \\
\text { committees }\end{array}$ & $\mathrm{N}$ & $\mathrm{N}$ & $\mathrm{N}$ & $\mathrm{N}$ & $\mathrm{N}$ & & \\
\hline $\begin{array}{l}\text { Briefings organised } \\
\text { for Parliamentary } \\
\text { committee }\end{array}$ & $\mathrm{N}$ & $\mathrm{N}$ & $\mathrm{N}$ & $\mathrm{N}$ & $\mathrm{N}$ & & \\
\hline $\begin{array}{c}\text { Summaries } \\
\text { submitted to } \\
\text { Parliament }\end{array}$ & $\mathrm{N}$ & $\mathrm{N}$ & $\mathrm{N}$ & $\mathrm{N}$ & $\mathrm{N}$ & & \\
\hline
\end{tabular}

\section{3) Parliamentary procedures for SAI reports}

There is no special committee in the Parliament for dealing with SAO reports. The Budget and Financing Committee is a designated for handling SAO reports. This committee is usually chaired by a member of the opposition party; based on procedure.

In practice, individual audit reports have not been discussed in Parliament.

In June 2013 the State Audit Office signed a memorandum of co-operation with the Parliament of the Republic of Macedonia which regulates the areas and the methods of co-operation between the two parties.

\section{Staffing}

A few employees are serving the Budget and Financing Committee. Their role is defined in the Parliament Rulebook and other Parliament acts, therefore the SAO cannot give a suitable response. SAO has authorised staff member to communicate with the Parliament. The Parliament has done the same, enabling them to communicate as needed. 


\section{SAl involvement in consideration of reports by Parliament}

The AG attends the plenary sessions of the Parliament when the SAO annual report is reviewed. The AG briefly presents the content of the annual report and provides answers to the questions raised. At plenary sessions, issues on individual audit reports submitted to the Parliament might also be raised, in which case the AG provides a suitable explanation.

\section{4) SAI reports}

In the annual report sent to the Parliament the SAO focuses on generic/systemic problems and recommendations;

SAO considers the issue of set up and functioning of internal control systems very important, so it is a subject that is highlighted in SAO audit reports; related to this issue, in 2015 the SAO conducted 13 performance audits on financial management and control, internal audit and their harmonisation.

All SAO audit reports contain conclusions, recommendations and audit opinions.

\section{5) Follow-up on SAI reports}

The SAO keeps track of the conclusions and the recommendations accepted by auditees by using SAPRI software. Follow-up audits and reviews are conducted at the beginning of each calendar year to identify the degree of implementation of recommendations of the final audit reports issued in the previous year.

The Macedonian government is required to report on the implementation of SAO recommendations.

\section{6) Audits on Parliament's request}

The Parliament may request an audit, in line with the guidelines for proposing audits for the SAO annual programme (an internal SAO act). No request has been submitted, so far.

\section{7) Work programme}

The SAO is independent in choosing the entities to be audited.

\section{8) Level and frequency of contacts}

There is communication between the AG and the President of the Parliament, and with the President of the Budget and Financing Committee in the Parliament, especially during the preparatory phase of the plenary session when the SAO annual report is on the agenda.

Communication between the SAO and the Parliament often takes place through the appointed staff members for communication in both institutions.

\section{9) Good practice}

The SAO is always willing to improve co-operation with Parliament. In co-operation with the Netherlands Court of Audit, a manual was produced "Introduction to audit reports", which was intended for MPs, to facilitate proper understanding of audit reports. 


\section{0) Perspective}

The Parliament should create conditions for reviewing audit reports (creating a special committee or within the existing Parliamentary committees) by providing sufficient trained experts, who will be able to understand and analyse the audit reports. The SAO is always ready to give the necessary assistance through briefings and working sessions. 


\section{GERMANY}

Bundesrechnungshof

\section{1) Legal framework}

Article 114.2 German Constitution (Basic Law) guarantees the existence of the German SAl and the judicial independence of its members. It provides for audit coverage of the budget and capital accounts, of federal financial management and budget execution, prescribing the audit criteria of regularity, compliance and performance. It also requires the German SAI to report to both Houses of Parliament and the Federal Government at least annually.

The Bundesrechnungshof Act contains detailed provisions about the status of the SAI as an independent institution of government audit only subject to the law, the status of its members and the collegiate decision making procedures.

Supplementary provisions on the German SAl's functions, audit subjects, audit criteria, audit procedure, reporting and good governance work are found in the Federal Financial regulations, our Federal Budget Code (Articles. 88 et seq.) and the Budgetary Principles Act (Articles. 54 et seq.).

\section{2) SAl reporting practices}

The German SAl's audit reports do not distinguish between financial, compliance and performance audit. They are usually comprehensive audit reports covering all aspects to some extent, with a focus placed on performance audit.

Each year, the German SAI carries out some 1,300 audits, and reports on the relevant findings to the audited bodies, i.e. mainly the Federal Government departments (ministries) through audit letters, giving auditees the opportunity to comment on these preliminary reports. An annual report is compiled from the major audit findings and audit recommendations developed during these audits, and is sent to the two Houses of Parliament and the Federal Government (Article 97.1 Federal Budget Code) in the last quarter of each year.

The annual report includes a final section on how the SAI has carried out its mandate. The German SAI may also at any time issue special reports to inform the legislative bodies and the government of matters of particular significance (Article 99 Federal Budget Code). The annual report and the special reports are published as Parliamentary papers, and are dealt with primarily by the Public Accounts Committee (PAC) of the Budget Committee of the Bundestag (the directly elected House of the German Parliament). The PAC supports most of the SAI's conclusions and recommendations.

The findings, conclusions and recommendations of each audit are included in a management letter. The President of the German SAI has an ex officio function as Federal Performance Commissioner. In this capacity he/she may conduct audits. The results of these are published in a series of audit opinions. Such audits often have a horizontal approach.

The German SAI has an advisory function. The SAI may issue advisory reports looking at issues of its own choice and advise the Government and Parliament on matters of topical interest. The SAI may also provide advice in the budget cycle. 


\section{Procedures for sending reports to Parliament}

The German SAI provides information to the PAC on its audit findings to gain the PAC's support.

The SAI may issue advisory reports looking at issues of its own choice, and advise the Government and Parliament on matters of topical interest. The SAI may also provide advice within the budget cycle.

All facts and figures undergo a review process before the final report is issued. The audited body receives the draft audit report and may comment on it. In this way any controversies about the audit findings can be resolved beforehand.

\section{Number and type of reports}

\begin{tabular}{|c|c|c|c|c|c|c|c|}
\hline & $\begin{array}{l}\text { Financial } \\
\text { audit } \\
\text { reports }\end{array}$ & $\begin{array}{l}\text { Compliance } \\
\text { audit reports }\end{array}$ & $\begin{array}{c}\text { Performance audit } \\
\text { reports }\end{array}$ & $\begin{array}{l}\text { Other reports } \\
\text { or documents }\end{array}$ & $\begin{array}{l}\text { Annual } \\
\text { activity } \\
\text { reports }\end{array}$ & $\begin{array}{l}\text { Reports at } \\
\text { request of } \\
\text { Parliament }\end{array}$ & Remarks \\
\hline Number submitted & & & & & & & \\
\hline $\begin{array}{c}\text { Number discussed } \\
\text { by Parliament }\end{array}$ & & & & & & & \\
\hline $\begin{array}{l}\text { Submitted to } \\
\text { Speaker }\end{array}$ & $\mathrm{Y}$ & $\mathrm{Y}$ & $\mathrm{Y}$ & $\bar{Y}$ & $\mathrm{Y}$ & $\mathrm{Y}$ & \\
\hline $\begin{array}{l}\text { Submitted to Chair } \\
\text { of dedicated } \\
\text { committee }\end{array}$ & $\bar{Y}$ & $Y$ & $\bar{Y}$ & $Y$ & $\mathrm{Y}$ & $\mathrm{Y}$ & \\
\hline $\begin{array}{l}\text { Copied to other } \\
\text { relevant } \\
\text { committees }\end{array}$ & & & & & & & \\
\hline $\begin{array}{l}\text { Briefings organised } \\
\text { for Parliamentary } \\
\text { committee }\end{array}$ & $\mathrm{Y}$ & $\bar{Y}$ & $\bar{Y}$ & $Y$ & $\bar{Y}$ & $\bar{Y}$ & \\
\hline $\begin{array}{l}\text { Summaries } \\
\text { submitted to } \\
\text { Parliament* }\end{array}$ & & & & & & & \\
\hline
\end{tabular}

* Each annual report and special report is preceded by a summary.

\section{3) Parliamentary procedures for SAI reports}

The annual report to Parliament is adopted by the German SAI's Board and forwarded by the German SAl's President to the Presidents (Speakers) of the two Houses of Parliament and to the Federal Government.

The Bundestag (the directly elected House of the German Parliament) refers the German SAI's annual report to Parliament's Budget Committee and which is passed on to the PAC. 
PAC designates the rapporteurs and determines the programme for the discussion of the German SAI's annual report.

PAC discusses each annual report item, and passes resolutions requiring the ministries to take steps to make sure that the German SAI's recommendations are implemented, and to report within six months about the steps taken by the ministry. Finally, the PAC evaluates the overall result of its discussions and decides about measures to be recommended in connection with granting discharge to the Federal Government. The PAC's report and draft resolution are passed to the plenum of the Bundestag. This report is the basis for granting discharge to the Federal Government (Article 114 paragraph 1 German Constitution, Article 114 Federal Budget Code).

\section{Staffing}

The Budget Committee has 41 members. They discuss and propose a resolution on the annual Budget Act and budget (also for SAl's budget), a resolution proposal for granting discharge (on the basis of PAC deliberations), discuss all projects with a bearing on the budget, discuss excess and extraordinary expenditures, and release of blocked funds. They are supported by the, rapporteur system (1 principal rapporteur and 4 co-rapporteurs).

The PAC is a 17 member standing committee. All its members are also members of the Budget Committee. PAC composition reflects the strength of Parliamentary groups. It discusses and decides about all audit related issues. The SAl's annual report that serves as basis for granting discharge to the Federal Government and other SAI reports. It deliberates under the rapporteur procedure, according to which particular MPs are responsible for specified ministries or subject areas of the executive branch, and prepare the decisions of the full PAC. It meets 8-10 times a year with a fixed agenda during parliamentary session. Its discussions are attended by one permanent representative each (State Secretary level) of the Finance Ministry and the SAI, and of the line ministry and by the SAI's Panel responsible for the report.

All MPs and Parliamentary committees can rely on the support of the Bundestag's research and documentation services. Details about the numbers of staff assigned to the Bundestag's Budget Committee and PAC can only be obtained from the Bundestag administration.

\section{SAl involvement in consideration of reports by Parliament}

The audit recommendations are discussed by the PAC, and usually most of them are supported by the Committee.

The Bundestag and, above all, its Budget Committee and PAC rely on the German SAl's expert advice especially in connection with major government projects and programmes that pose a high risk to value for money. The meetings of the PAC are always attended by relevant Members of the German SAI who are usually given the opportunity to speak on the issues in question. It is also common practice for SAI members to brief the Budget Committee and the PAC. They also brief members during the stage of budget preparation, and, where appropriate, they brief other Parliamentary committees.

\section{4) SAI reports}

The German SAI may select its audit work as it deems fit. All of the above may be treated in audit reports. As a rule, all audit reports have conclusions and recommendations. 


\section{5) Follow-up on SAI reports}

To enhance audit impact, the German SAI follows up on its audit recommendations. It asks the audited body what action it has taken in response to the recommendations and, where appropriate, requires relevant evidence. The findings generated may motivate reporting to Parliament or a follow-up audit. The relevant panel of SAI members decides about the conduct, nature and timing of follow-up. In addition, as stated above, the SAI is supported by the PAC that may set deadlines for recommendations to be implemented. The German SAI is also involved as an expert adviser in the budget preparation procedure.

\section{6) Audits on Parliament's request}

Given the constitutional provision on the German SAl's independence, Parliament may request - but not order - the SAI to audit any particular issue and report on it. The SAI usually accedes to such requests, not only out of courtesy but because Parliament is often an ally in pressing for corrective action in response to the SAl's audit conclusions and recommendations. Parliamentary audit requests would probably be refused only where there is a risk that audit conclusions and recommendations could become a 'political football' or where it appeared that the request was to divert the SAl's audit resources from other pressing issues.

\section{7) Work programme}

The German SAI develops its Work programmes in full independence, and is free to select audit matters as it deems fit. However, it may take into account Parliamentary requests and ongoing or imminent debates on important issues.

\section{8) Level and frequency of contacts}

There are regular formal and informal contacts between the SAl's members and the MPs on the Budget Committee, PAC and, where appropriate, other Parliamentary committees, especially through discussions of SAI representatives with reporting members of the committees.

Our Panels (of SAI Members) introduce themselves to 'their' rapporteur and offer their assistance. The new chairpersons and representatives of the task forces of each Parliamentary group are approached personally by our President and Vice-President.

\section{9) Good practice}

The SAI is proactive in participation in the Parliamentary and inter-ministerial discussions held during the budget preparation stage.

In addition, the SAI may do real-time audits of spending programmes such as building a road. The SAI may accompany such projects, and audit each stage once the decision to proceed to the next project stage has been made. Thus the SAI may help make savings while a programme is still under way.

\section{0) Perspective}

The SAI is not aware of any weaker points.

11) Are there any other relevant features of the current relations between the SAI and Parliament that you would like to highlight, and how have they evolved over the past five years?

The SAI is not aware of any relevant features at the moment. 


\section{GREECE}

Hellenic Court of Audit

\section{1) Legal framework}

The Legal framework for the Court's obligations towards the Greek Parliament, as defined in the Constitution, the Codified Law for the Hellenic Court of Audit (L. 4129/2013) and the Organic Budget Law (L. 4270/2014), provides for two reports:

The annual report on findings, setting out the results of the Court's operations, its observations and suggestions for improvements to systems and the law.

The annual declaration, including the Court's opinion on the annual financial statement and the balance sheet of the State.

\section{2) SAI reporting practices}

The Plenum of the Hellenic Court of Audit (HCA), after having taken into consideration the reports of the Court's Commissioners based on data derived from their duties, delivers the annual report, the main content of which is as follows:

- Report on the results of audit operations and observations.

- Remarks on detected violations of administrative and financial rules or of the Budget.

- Suggestions for measures to prevent the recurrence of violations.

- Suggestions of measures to reform and improve legislation on the jurisdiction of the HCA

This report is forwarded to the auditees (ministers), via the Minister of Finance. The comments of the auditees are included in a joint issue and are communicated to the HCA by the Minister of Finance in a two month period.

More specifically, the Annual Report consists of the following parts:

Part I A brief description of the HCA activities for the relevant year (audits, judicial decisions, participation in international congresses etc.) as well as brief summaries of the findings of any special audits carried out.

Part II General Observations on public expenditure.

Part III Analysis of the most significant audit findings (depending on the threshold specified for the relevant year). These findings are considered as supporting documentation of the observations of Part II. Additionally, there is a special chapter dedicated to the public procurement, including pre-contractual audits.

Part IV Suggestions.

Joint Issue The auditees comments. 
The President of the HCA submits the annual report to the President of the Parliament. The report is debated in the Parliament's plenary within the context of parliamentary control. The annual report is published in the State Gazette and on the Court's website, and is thus open to the public.

The reporting practices for the annual declaration of the Court are as follows. Each year, before the end of June, the annual budget execution report and the balance sheet of the State, along with other financial statements, are submitted by the Ministry of Finance to the competent Office of the Commissioner of the HCA, which, within two months and after having examined their correctness and reliability, returns them to the State's General Accounting Office along with its report. Within 20 days from despatch, the Minister of Finance submits to the Court his views and commentary on the report.

The HCA, in Plenum, after having taken into account the report of the competent Office of the Commissioner and the Minister's views, decides on the correctness and the reliability of the budget execution annual report, the balance sheet and the other financial statements of the State by a report (Declaration), which is submitted to the Ministry of Finance by the end of October of the relevant year.

The annual budget execution report, the balance sheet and other financial statements of the central Government, along with the Declaration of the HCA, are placed in Parliament for ratification on the initiative of the Minister of Finance, at the latest by the end of November of each year and, in any case, before the following year's State Budget is submitted to Parliament.

\section{Procedures for sending reports to Parliament}

Briefings and presentations by the HCA to Parliamentary committees (Financial Statement and Balance Committee, Financial Affairs Committee) have recently taken place (2013-2014) on a non-institutionalised basis.

\section{3) Parliamentary procedures for SAI reports}

Parliamentary rules in force do not provide for any hearings before Parliamentary committees with the involvement of the HCA.

As briefly stated above, in 2014 two special audit reports (financial and compliance) were presented and discussed before the relevant parliamentary committees (i.e. the "Committee on the Financial Statement and the General Balance Sheet and the implementation of the State Budget", "Standing Committee on Cultural and Educational Affairs» and the "Standing Committee on Social Affairs»).

\section{Staffing}

Details of Parliamentary staff supporting the committee(s) dealing with SAI reports are not applicable.

\section{SAI involvement in consideration of reports by Parliament}

As stated above, the President of the HCA submits the annual report to the President of the Parliament. Attendance at the relevant debates has not yet been institutionalised.

\section{4) SAI reports}

The SAI focuses on generic/systemic problems and recommendations in its communications to Parliament. 
The set up and functioning of internal control systems is not a subject that is highlighted in SAI reports.

All audit reports contain clear conclusions and audit opinions.

\section{5) Follow-up on SAI reports}

Conclusions and recommendations that are not implemented by auditees are repeated in the next report.

Follow-up audits have been included in the Annual Audit Programme for 2016.

\section{6) Audits on Parliament's request}

The HCA delivers opinions on bills of law, regulating significant issues of financial management of the General Government Entities, submitted by the Minister of Finance. (Article 1, Law No. 4129/2013) as well as on bills pertaining to pension issues, when allocated at the expense of the State Budget, under 73 paragraph 2 of the Constitution.

\section{7) Work programme}

Given the jurisdictional nature of the Court's workings, the annual audit programme is decided by the Court's plenum, independently from any consultation or suggestion of the Parliament.

\section{8) Level and frequency of contacts}

Apart from what was stated above, no regular contact has been set up.

\section{9) Perspective}

Institutionalisation can enhance the relationship between the HCA and the Parliament, if the former's jurisdictional status is fully respected. 


\section{HUNGARY}

State Audit Office of Hungary

\section{1) Legal framework}

The State Audit Office of Hungary (SAO) is the supreme financial and economic audit institution of the National Assembly, reporting to the National Assembly. With its findings, recommendations and advice based on its audit experience, the SAO assists the National Assembly, its committees and the work of the audited entities, thus facilitating well-governed state operations.

The SAO works on the basis of an audit plan approved by its President. The President of the SAO informs the National Assembly about the audit plan and any amendments. Within its statutory competence, the SAO conducts audits under decisions taken by the National Assembly, and may conduct audits upon the request of the government. The frequency of the audits performed by the SAO is determined by law or, in absence of relevant statutory provisions, by the President of the SAO.

As required by provisions of law, the SAO audits the financial management of political parties; the utilisation of the contributions made available by the National Assembly to the groups of Members of Parliament representing each political party; the utilisation of normative subsidies and subsidies for specified purposes allocated from public funds to churches as well as to institutions and organisations maintained and operated by churches; and the data on the utilisation of the budget for special operating costs of the national security services.

\section{2) SAI reporting practices}

The President of the SAO arranges for the submission of the annual report of the SAO and of the report on the central budget and its implementation (final accounts) to the National Assembly. The reports are addressed to the Speaker of the National Assembly.

The National Assembly discusses the bill on the central budget, together with the opinions of SAO and the Fiscal Council. The Government submits the bill on final accounts to the National Assembly no later than eight months after the end of the budget year. The bill on the final accounts is forwarded to the SAO two months before its submission to the National Assembly. The National Assembly discusses the bill on the final accounts together with the opinion of SAO.

In the annual report prepared for the National Assembly, the President of the SAO provides information on the audit activity, operation and financial management of the organisation in the preceding year, as well as on the measures taken on the basis of audit findings.

\section{Procedures for sending reports to Parliament}

The annual report of the SAO is adopted by the National Assembly. During the joint general debate of the report on the activities and operation of the SAO, the President of the SAO makes an introductory speech.

The reports on the central budget and its implementation (final accounts) are discussed on the same day as the respective bills. Introductory speeches of SAO's President are also made on these occasions. 


\section{Number and type of reports}

All SAO reports are electronically forwarded to MPs and office-holders of the National Assembly.

In 2015, the SAO officially submitted three reports to the National Assembly. Information papers summarising the audits were also submitted in the form of 1-2-page letters.

The SAO'S audit plan was handed over personally by its President but that is not a report.

The analyses submitted are not reports, so there was no legal obligation to submit them. They were sent for information purposes only, which means that they are not registered at the National Assembly and they are not put on the agenda for debate.

Should any of the committees decide to discuss one of the SAO's reports, the SAO is invited to give information thereon. The plenary meeting does not discuss or register these reports. The committees are free to decide what to put on their agenda.

\section{3) Parliamentary procedures for SAI reports}

The annual report of the SAO is discussed by the relevant Parliamentary committee and a proposal for a decision is made. The proposal is also discussed in the course of the general debate, while the SAO's President is present to answer questions. Once the report is adopted, a Parliamentary decision is taken. The committee can involve external experts as well, but is not the general practice. Debates on SAI reports can be held both in committees and/or plenary sessions. Under the National Assembly's Rules of Procedure, committees have the liberty to discuss any reports. They are typically informed about the SAO's warning letters and other relevant topics. The work of MPs is also supported by SAO information about such topics under discussion that SAO has also audited. All SAO reports are electronically distributed to the Members of the National Assembly. MPs are also entitled to address questions to the SAO's President, either directly or via the National Assembly, to be answered within 15 days.

\section{Staffing}

There is only one committee out of the 17 that discuss the three reports the SAO has an obligation to submit. Minutes of the debates are taken by the clerk of the National Assembly.

At SAO, several staff members are involved in parliamentary relations at various levels. The President (in his absence the Vice-President) of the SAO, as well as its supervisory managers participate in the professional work of the committees. Colleagues from the legal department monitor agenda items and prepare written documentation related to draft bills. The SAO's President is entitled to join the debate at any time. One colleague is assigned to organise all communication with the National Assembly. Colleagues from the communication and international departments are involved in preparing related publications both in Hungarian and foreign languages.

\section{4) SAI reports}

The SAO does not focus on generic/systemic problems and recommendations in its communications to the National Assembly, however the internal control system has been a key issue in the course of auditing local governments. A study on this issue was published in January 2015. 


\section{5) Follow-up on SAI reports}

The SAO forwards its report on its audit findings to the head of the audited entity. The head of the audited entity develops an action plan in response to the findings in the report. In the event that the head of the audited entity fails to submit the action plan on time, or submits an action plan that is unacceptable, the President of SAO may initiate criminal proceedings or disciplinary action against the head of the audited entity. The President may also apply for the suspension of the disbursement of subsidies or other allowances due to the audited entity from a subsystem of public finances and the possibility of receiving a portion of the pledges of $1 \%$ of the personal income tax. The SAO may verify the implementation of the measures contained in the action plan in a follow-up audit. If the measures fail to prove effective, or taking such measures is not possible, or it is otherwise justified by the nature or weight of the given matter, the President of the SAO may initiate that the relevant committee of the National Assembly discuss the report and the findings, and hear the head of the audited entity.

The government is not required to report on the implementation of SAI recommendations.

\section{6) Audits on Parliament's request}

Within its statutory competence, the SAO may conduct audits upon the request of the government.

In practice, the President of the SAO submits to the National Assembly the three reports prepared on the basis of legal obligations and registered by the National Assembly. These are the SAO's annual report, the opinion on the draft budget bill and the report on the audit of the execution of the budget (final accounts). This happens three times a year. The SAO's annual report is submitted in the spring of the year following the subject year. The submission of the reports on the draft budget and the final accounts depends on the time when the government submits the respective draft bills. The government has to submit the draft bill on the execution of the budget to the National Assembly by 31 August at the latest. Both the draft bills on the budget and on the execution of the budget are discussed together with SAO's respective opinion/report.

\section{7) Work programme}

The SAO works on the basis of an audit plan (annual work plan) approved by its President. The President of the SAO informs the National Assembly about the audit plan and any amendments to it. There is no preliminary consultation.

\section{8) Level and frequency of contacts}

There are regular daily contacts between the Office of the National Assembly and the SAO's Secretariat of the President and Managerial Department. One colleague is specifically assigned to organise all interactions with the National Assembly.

The SAO is the supreme financial and economic audit organisation of the National Assembly, therefore a great emphasis is put on the utilisation of our work. The National Assembly has a primary role in the utilisation of SAO reports. Our primary objective is that our findings and recommendations are utilised in the legislative processes to the greatest possible extent. The SAO considers it highly important that lawmakers can be informed at the right time in the necessary depth about the long-term socioeconomic impacts and fiscal-monetary context of the given pieces of legislation. The findings, correlations and recommendations of the reports assist law-makers in taking their decisions on the basis of information substantiated by audits. 
To keep contact between the SAO and the National Assembly, SAO has created a co-operation with the Office of the National Assembly. The co-operation agreement is subject to continuous renewal, in harmony with the organisational changes of the two institutions. In mutual co-operation, SAO gives and receives wide-spread and direct information. We regularly receive the documentation supporting plenary meetings, as well as invitations to committee meetings (in certain cases with background material).

Whenever a SAO report is published, it is automatically sent to the Speaker of the National Assembly, as well as to the chairs and vice chairs of the committees in charge of audit and budget issues. Officers of the National Assembly and MPs are informed about the availabilities of SAO reports and press summaries via e-mails. The SAO's reports can be downloaded directly from the website of the National Assembly as well. The work of the National Assembly is followed-up, assessed and utilised at SAO daily.

\section{9) Good practice}

The main endeavour of the SAO, as the supreme financial and economic audit organisation of the National Assembly, is to have its audits and findings formulated in its reports utilised to the greatest possible extent in the course of legislative procedures. Therefore, SAO regularly formulates recommendations to the law-making programme of the National Assembly both for the autumn and the spring sessions.

In its recommendations prepared and sent to the National Assembly for its law-making programme for the spring of 2016, the SAO drew attention to its reports already published in connection with the draft bills to be submitted, as well as to its audits included in its audit plan and to be carried out in the first half of the year.

In order to achieve its strategic objectives, the SAO has sent its recommendations to the Speaker, the Deputy Speakers and the group leaders of the National Assembly. In its letter sent to the heads of 11 committees and eight sub-committees operating along with the committees, the SAO specifically drew attention to such topics that might be of interest for the given committee. Within the framework of the co-operation between SAO and the National Assembly, the recommendation is also available on the website of the National Assembly.

Within its competence, the SAO may prepare analyses and studies. In connection with the tasks of the President, the SAO prepares analyses and studies to assist the Fiscal Council with the performance of its tasks.

\section{1) Are there any other relevant features of the current relations between the SAI and Parliament that you would like to highlight, and how have they evolved over the past five years?}

More emphasis has been put on SAO's supporting activities to the National Assembly. It is of utmost importance to the SAO that law-makers can be informed about long-term socioeconomic effects and the fiscal-financial context of the given pieces of legislation at the appropriate time, and in suitable detail. Consequently, the number of information papers, studies and analyses has increased. 


\section{IRELAND}

Office of the Comptroller and Auditor General

\section{1) Legal framework}

The Comptroller and Auditor General is a Constitutional Officer who holds office under Article 33 of the Irish Constitution 1937.

The Legislation which governs the work of the Comptroller and Auditor General and the SAI Office are as principally contained in the Comptroller and Auditor General (Amendment) Act 1993.

The results of audit activity are reported to Parliament in two main ways:

Through audit certificates or reports which give an audit opinion on the accuracy of the financial statements / accounts.

Through reports on the financial management of individual entities and other matters likely to be of concern to Parliament.

The Committee of Public Accounts (PAC) which is a standing Parliamentary committee also plays a key role in the process of public accountability. The Auditor General (C\&AG) of the SAl attends meetings of the PAC as a permanent witness. The results of the C\&AG's independent examination provide a firm foundation for PAC enquiry. The Committee's effectiveness is enhanced by its having the C\&AG's reports as a starting point, and in turn the C\&AG's scrutiny gains significantly in impact and effectiveness, because the reports are considered and followed through by the PAC.

The PAC examines and reports to Parliament on its review of accounts audited by the C\&AG and the reports on them. These include the appropriation accounts of government departments and offices and the accounts of Health Boards and VECs, as well as the financial statements of non-commercial Statesponsored bodies.

The PAC also examines other statutory reports of the C\&AG:

The C\&AG's reports on the examinations of economy, efficiency and effectiveness evaluation (VFM).

Other reports made by the C\&AG under the Comptroller and Auditor General (Amendment) Act 1993.

\section{2) SAI reporting practices}

The SAI sends financial audit and performance audit reports to the standing Public Accounts Committee in the Parliament.

The SAI reports separately on individual audits. It also produces cross cutting reports on issues affecting several departments and also sectoral reports e.g. the education sector.

The SAI publishes an annual corporate report on its website, which includes performance statistics for its audit work. 
Each government department audited is legislatively required to present its accounts for audit to the SAI by 31 March and the SAI must complete its audit by the statutory deadline of 30 September annually.

\section{Staffing}

The SAI has an official located in Parliament offices who provides briefing material to the PAC in advance of the examination of a government or State body's accounts and any related performance reports.

\section{Number and type of reports}

\begin{tabular}{|c|c|c|c|c|c|c|c|}
\hline & $\begin{array}{l}\text { Financial } \\
\text { audit } \\
\text { reports }\end{array}$ & $\begin{array}{l}\text { Compliance } \\
\text { audit reports }\end{array}$ & $\begin{array}{c}\text { Performance audit } \\
\text { reports }\end{array}$ & $\begin{array}{l}\text { Other reports } \\
\text { or documents }\end{array}$ & $\begin{array}{l}\text { Annual } \\
\text { activity } \\
\text { reports }\end{array}$ & $\begin{array}{l}\text { Reports at } \\
\text { request of } \\
\text { Parliament }\end{array}$ & Remarks \\
\hline Number submitted & 42 & - & 32 & - & - & - & \\
\hline $\begin{array}{c}\text { Number discussed } \\
\text { by Parliament }\end{array}$ & & & & & & & \\
\hline $\begin{array}{l}\text { Submitted to } \\
\text { Speaker }\end{array}$ & $Y$ & - & $Y$ & - & - & - & \\
\hline $\begin{array}{c}\text { Submitted to Chair } \\
\text { of dedicated } \\
\text { committee }\end{array}$ & $Y$ & - & $Y$ & - & - & - & \\
\hline $\begin{array}{l}\text { Copied to other } \\
\text { relevant } \\
\text { committees }\end{array}$ & $\mathrm{N}$ & - & $\mathrm{N}$ & - & - & - & \\
\hline $\begin{array}{c}\text { Briefings organised } \\
\text { for Parliamentary } \\
\text { Committee }\end{array}$ & $\mathrm{Y}$ & - & $Y$ & - & - & - & \\
\hline $\begin{array}{l}\text { Summaries } \\
\text { submitted to } \\
\text { Parliament }\end{array}$ & $Y$ & - & $Y$ & - & - & - & \\
\hline
\end{tabular}

3) Parliamentary procedures for SAI reports

The PAC is a standing Parliamentary committee. It plays a key role in the process of public accountability.

The C\&AG of the SAl attends meetings of the PAC as a permanent witness. The results of the C\&AG's independent examination provide a firm foundation for PAC enquiry. The Committee's effectiveness is enhanced by its having the C\&AG's reports as a starting point, and in turn the C\&AG's scrutiny gains significantly in impact and effectiveness because the reports are considered and followed through by the PAC.

The PAC examines and reports to Parliament on its review of accounts audited by the C\&AG and the reports on them. These include the appropriation accounts of government departments and offices and 
the accounts of Health Boards and VECs, as well as the financial statements of non-commercial Statesponsored bodies.

\section{Staffing}

The SAl appoints an official during the term of the Public Accounts Committee. This official liaises between the Committee and the SAl, and provides the committee members with briefing material and potential issues arising in advance of meetings.

\section{SAI involvement in consideration of reports by Parliament}

The C\&AG of the SAI attends meetings of the PAC as a permanent witness to answer any questions from the PAC or from witnesses in respect of the reports which are being examined.

\section{4) SAI reports}

The SAI focuses on generic/systemic problems and recommendations in its communications to Parliament.

The set up and functioning of internal control systems is a subject that is highlighted in SAI reports.

All audit reports contain clear conclusions and audit opinions.

\section{5) Follow-up on SAI reports}

The SAI keeps an electronic record internally of all its recommendations and timelines for implementation. These may be subject to follow up reports.

The PAC convey the recommendations following each hearing to the Finance Department. The PAC produce a report on the outcome of the implementation of the recommendations.

\section{6) Audits on Parliament's request}

The C\&AG of the SAI has a broad mandate under the Constitution and Legal framework, particularly by the Comptroller and Auditor General (Amendment) Act, 1993. The C\&AG has been given broad Constitutional powers and legal protections, and is not subject to the control or direction of any other authority, with the power to report to Parliament on any audit-related matter. There is a specific mandate for financial, compliance, and performance audits; powers to audit all central government funds; access to documentation and premises of audit bodies; and the right and obligation to report to Parliament as deemed necessary.

Consideration may be taken of Parliamentary advices, but the SAI ultimately has the power to decide what audits and reports to conduct under the statutory remit.

The C\&AG of the SAI has sole powers to decide on what performance topics are examined under his statutory remit. He is not compelled or influenced to conduct any performance audit by the PAC or Parliament. The Parliament/PAC does not come up with suggestions for audit topics. If it happened that the PAC asked the SAI to perform an audit on a particular topic due to adverse news coverage for example, the C\&AG would consider it in the context of the SAI's remit. The Work programme and the topic's importance would be considered, but the decision as to whether or not to carry out an audit remains the SAI's alone. 


\section{7) Work programme}

The annual Work programme is decided by the SAI alone. The PAC uses the outputs from the SAI's annual Work programme to set the agenda for the work of the committee for the following year. See also the previous answer.

\section{8) Level and frequency of contacts}

The SAI and PAC committee meet formally on a weekly basis to examine reports. Informal matters may be discussed before meetings.

\section{9) Good practice}

The allocation of a liaison person by the SAI to the PAC contributes to the smooth running of administrative affairs, as committee members are fully briefed and may ask questions before formal committee meetings with witnesses.

\section{0) Perspective}

No significant weaker points noted. 


\section{KOSOVO*}

Office of the Auditor General

\section{1) Legal framework}

Constitution: Article 138, Reports of the Auditor General (AG) of Kosovo states:

1. The Auditor General of Kosovo addresses the Assembly:

a) to report on the execution of the State budget;

b) to give an opinion on the report of the Government on its expenditures of the previous year before it is adopted by the Assembly;

c) to inform the Assembly on conclusions of audits when requested.

2. The AG of Kosovo submits an annual report on the activities of the office to the Assembly.

Law on the Auditor General and the National Audit Office of the Republic of Kosova 05/ L-055, Article 20 and 23:

20.1. The AG shall adopt a three year Strategic Audit Plan updated on annual basis;

20.2. The AG shall adopt an Audit Plan annually and submit it to the COPF, until 31st October;

20.3. The AG may, upon the written request of the Assembly or the Government, conduct additional audits.

23.2. When reporting on statutory Regularity audits, the National Audit Office shall submit final audit reports to each audited institution and to the Assembly no later than ninety (90) days after the submission of the Budget Organisation's final AFS. In case the audited institution is a municipality, the final Audit Report shall also be submitted to the concerned municipal Assembly.

23.3. For the audit of the Government's Annual Report on the execution of the Kosovo Budget, the National Audit Office shall submit the Annual Audit Report to the Assembly within the deadline set forth in the Law on Public Finance Management and Accountability.

23.7. The AG shall annually present the Annual Audit Report in the Plenary Session of the Assembly;

23.8. The AG may at any time address the Assembly on any matter within the mandate of the National Audit Office.

This designation is without prejudice to positions on status, and is in line with United Nations Security Council Resolution $1244 / 99$ and the Advisory Opinion of the International Court of Justice on Kosovo's declaration of independence. 


\section{2) SAI reporting practices}

The NAO sends to the Parliament separately individual regularity audit reports and performance audit reports, the annual audit report on the State budget and its annual performance report. Upon the written request of the Assembly or the Government, the AG may conduct a regularity audit or performance audit on any of the institutions or entities as regulated by law.

The individual audit reports are addressed to the chair and members of the Committee on Oversight of the Public Finances (COPF), while the annual audit report and annual performance report are addressed to the Secretary General of the Assembly and the chair of the COPF, with copy to the Liaison Office for the Independent Institutions and Agencies, within the Assembly.

Some reports have deadlines.

- Based on the Law on Public Financial Management and Accountability 03/L-048, the AG prepares and submits to the Assembly a report on the financial statements of budget organisations and public undertakings for the previous fiscal year. If the budget organisation is a municipality, the report is also provided to the concerned municipal assembly. This report provides the AG's opinion on whether or not the financial statements give a true and fair view of the finances of such budget organisations and public undertakings. The report is submitted by 31 July following the end of the fiscal year to which the annual report relates.

- AG provides to the Assembly the annual audit report on the annual financial statements (AFS) of Kosovo's Budget, no later than 31 August of the following year.

- On annual basis within three months of the end of the year of account, the AG provides to the Assembly its annual report of the audit activities of the AG. The report includes the report of the independent audit of the accounts of the NAO of Kosovo.

The AG may at any time conduct a performance audit of any institution or entity, and the final report is submitted to the Assembly.

The AG prepares its annual working plan for submission within deadlines set by laws. It is presented to the COPF in the beginning of the audit season.

Copies of the audit reports of the AG are delivered to the audited body and made available to the public as well.

\section{Procedures for sending reports to Parliament}

See previous answers about the procedures of sending reports to the Parliament.

The audit team prepares briefings of the audit reports on review on the public hearings, for the MPs of the Committee. If necessary the reports and briefings are discussed with MPs at a preparatory meeting, usually held one day before the public hearing. 
Number and type of reports

\begin{tabular}{|c|c|c|c|c|c|c|c|}
\hline & $\begin{array}{l}\text { Financial } \\
\text { audit } \\
\text { reports }\end{array}$ & $\begin{array}{l}\text { Compliance } \\
\text { audit reports }\end{array}$ & $\begin{array}{l}\text { Performance } \\
\text { audit reports }\end{array}$ & $\begin{array}{l}\text { Other reports } \\
\text { or documents }\end{array}$ & $\begin{array}{l}\text { Annual } \\
\text { activity } \\
\text { reports }\end{array}$ & $\begin{array}{l}\text { Reports at } \\
\text { request of } \\
\text { Parliament }\end{array}$ & Remarks \\
\hline Number submitted & 100 & & 14 & & 1 & & Total 114 \\
\hline $\begin{array}{c}\text { Number discussed } \\
\text { by Parliament }\end{array}$ & 50 & & 4 & & 3 & & \begin{tabular}{|c|} 
Both the \\
annual audit \\
report for \\
2013 and \\
2014 have \\
been \\
reviewed in \\
2015, \\
because of \\
the election \\
and new \\
legislation in \\
place during \\
2014.
\end{tabular} \\
\hline $\begin{array}{c}\text { Submitted to } \\
\text { Speaker }\end{array}$ & $\mathrm{N}$ & $\mathrm{N}$ & $\mathrm{N}$ & & $\mathrm{N}$ & & $\begin{array}{c}\text { NAO reports } \\
\text { are } \\
\text { addressed } \\
\text { to the } \\
\text { Parliament }\end{array}$ \\
\hline $\begin{array}{l}\text { Submitted to Chair } \\
\text { of dedicated } \\
\text { committee }\end{array}$ & $\mathrm{Y}$ & $\mathrm{Y}$ & $\mathrm{Y}$ & & $\mathrm{Y}$ & & \\
\hline $\begin{array}{c}\text { Copied to other } \\
\text { relevant } \\
\text { committees }\end{array}$ & $\mathrm{N}$ & $\mathrm{N}$ & $\mathrm{N}$ & & $\mathrm{Y}$ & & \\
\hline $\begin{array}{l}\text { Briefings organised } \\
\text { for Parliamentary } \\
\text { committee }\end{array}$ & $\bar{Y}$ & $\bar{Y}$ & $Y$ & & $\bar{Y}$ & & \\
\hline $\begin{array}{c}\text { Summaries } \\
\text { submitted to } \\
\text { Parliament }\end{array}$ & & & & & & & \\
\hline
\end{tabular}

\section{3) Parliamentary procedures for SAI reports}

The Internal Rules of Procedure for COPF regulates the procedures for handling reports of the AG laid down in Parliament. 
The COPF handles all reports of the NAO of Kosovo and it is chaired by the member of the opposition. COPF also handles audit reports (not produced by AG) as the annual report on the functioning of Public Internal Financial Control (PIFC) system in the public sector of Kosovo.

The COPF does not appoint a rapporteur.

At public hearings of the COPF, the highest responsible person (as Minister, Executive Directors) of the Budget Organisation is invited, to provide further information on the audit report on review.

Based on the Financial and Procedure Guidelines of the Assembly, COPF can use independent external experts for particular issues.

In committees and plenary sessions, COPF reviews the annual performance report of the NAO and send a report with recommendations for plenary session within three weeks from the date it accepts the report. The COPF reviews audit reports of the NAO. Priority is decided by vote. The COPF decide by vote which reports must be sent for review on plenary session, if there is no relevant regulation. The COPF review the annual audit report of NAO and sent a report with recommendations to the Assembly no later than 1 October every year ${ }^{37}$.

Other committees apart from COPF can consider audit reports in particular cases.

At public hearings, the COPF requires the audited body to send reports on actions taken by them on the recommendations given by the AG. Deadlines for these reports are usually within three months. These reports are not published

\section{Staffing}

The support staffs to the COPF are two people with law and economics background. They provide written research, analysis or briefings in preparation for debates on SAI reports, develop questions for the COPF to ask at hearings, and draft reports or other outputs of the COPF.

\section{SAI involvement in consideration of reports by Parliament}

The NAO prepares briefings which are discussed on preparatory meetings with MPs, if necessary.

Representatives of the NAO always attend Parliamentary meetings when audit reports are debated. The level of the representatives depends on the agenda of the meeting and the audit report which is on review. In particular cases $A G$ is invited. Someone from the top management or director of the of particular audit department for the audit report that is on agenda, attends the meeting.

The contact person for the Parliament monitors all hearings of the COPF, also plenary sessions and hearings of other committees if necessary.

\section{4) SAI reports}

The SAI focuses on generic/systemic problems and recommendations in its communications to Parliament.

$37 \quad$ Except special cases 
The set up and functioning of internal control systems is a subject that is highlighted in SAl reports.

All audit reports contain clear conclusions and audit opinions.

\section{5) Follow-up on SAI reports}

The SAI keeps track of conclusions and recommendations accepted by auditees.

The Parliament pays attention to the implementation of SAI recommendations in audit reports.

The follow-up of the extent to which our previous year's recommendations have been implemented is a consistent part of our audit. The number of unaddressed recommendations remains a concern, and effective measures are required to address this situation. In this regard, COPF requires reports on how the recommendations of the AG have been implemented.

While the individual auditees prepare action plans and reports on implementation of the recommendations given by AG in individual reports, Government as whole does not for the annual audit report. SAI reports are not used as input on the annual debate on draft budgets.

\section{6) Audits on Parliament's request}

The Law on AG and NAO 05/L-055: Article 20.3. states:

3.7 The AG may, upon the written request of the Assembly or the Government, conduct a additional audits.

During 2015, the Parliament requested AG to conduct the audit of the Radio Television of Kosovo. However, it is on the discretion of the AG to audit.

\section{7) Work programme}

The NAO prepares its annual work plan of audits and presents it to the COPF. While the regularity audits are mandatory for entities that are more than $50 \%$ publicly owned or receive funding from, or provide dividends for Kosovo Budget, the discussion is regarding performance audits, and suggestions might come up. However, the AG decides for the final plan.

\section{8) Level and frequency of contacts}

The AG or a person from higher management assigned by AG presents in almost all COPF meetings (at least twice a month). If necessary, informal contact with the chair is organised.

There are contacts at a day to day working level, if necessary.

The communication officer is the contact person for the Parliament. Deputy AG is tasked in general with relations with the Parliament.

\section{9) Good practice}

With the recommendation of the OAG (now NAO), during 2015, COPF has organised several hearings to review the performance audit report on maintenance and repair of official vehicles, together with five regularity audit reports of the institutions which have been in the audit scope for this performance audit, 
by comparing them. The highest responsible person of these institutions has been invited to the hearings and COPF has made recommendation to them about these reports.

\section{0) Perspective}

In co-operation with COPF, we are looking at the possibility of strengthening the mechanisms of increasing the percentage of implemented recommendations given by the AG.

To improve effective communication between the SAI and Parliament, NAO is considering the possibility of having a permanent contact person/auditor in Parliament. This discussion is still in the initial stages and the procedures are being evaluated.

11) Are there any other relevant features of the current relations between the SAI and Parliament that you would like to highlight, and how have they evolved over the past five years?

We consider that the relations between the SAI of Kosovo and Parliament are sustainable and in constant development. The Parliament support the AG on fulfilling its mandate and the role of SAI Kosovo is highly appreciated. 


\section{LATVIA}

State Audit Office

\section{1) Legal framework}

The State Audit Office (SAO of Latvia) is obliged by the Law to submit the report and auditors opinion on the annual report of the Republic of Latvia about the implementation of the state budget and the budgets of local governments.

Each year the SAO of Latvia is obliged to submit qualified opinions to the Speaker of the Parliament on the accuracy and reliability of the annual financial statements of the ministries or central government agencies.

The SAO of Latvia has to submit reports to the Parliament and the Cabinet of Ministers on the financial audits of auditees where discrepancies have been noted, or where no opinion could be offered. Parliament is also to be informed about all of the performance and compliance audits carried out by the SAO Latvia, with any other relevant findings.

\section{2) SAI reporting practices}

The SAO of Latvia is obliged by the law to submit the Report and Auditors opinion on the annual report of the Republic of Latvia about the implementation of the state budget and the budgets of local governments (by 15 September). The SAO of Latvia submits qualified opinions on the ministries and central government agencies to the Parliament, as well as Reports on Performance and Compliance audits. The SAO of Latvia sends out an overview of the implementation of audit recommendations within an audit field for no more than three years.

The SAO of Latvia reports separately on individual audits. The report on the annual report of the Republic of Latvia is addressed to the heads of Ministry of Finance and the Parliament, while other reports are addressed to the corresponding Ministries, and copied to the Committee of the Procurement and Audit (SPIRK) and other relevant committees if necessary.

After receiving an audit report, SPIRK sets a date for receiving a response on the audit conclusions and the irregularities found, as well as an action plan for resolving them, from the responsible institution of the auditee. The SAO of Latvia then submits additional commentaries on the answers received. SPIRK then holds meetings with the involved bodies.

The SAO of Latvia is eligible to receive draft legal enactments of the Parliament, and to offer its opinion if the proposed enactments can influence tax revenues and expenses of the State and local government budgets, or include actions with public property, financial resources of the EU, or from other international body origin which are part of state budget or budgets of local municipalities.

\section{Procedures for sending reports to Parliament}

There are no specific procedures for sending reports to the Parliament. The SAO of Latvia carries out presentations to SPIRK in the Parliament. 


\section{Number and type of reports}

\begin{tabular}{|c|c|c|c|c|c|c|c|}
\hline & $\begin{array}{l}\text { Financial } \\
\text { audit } \\
\text { reports }\end{array}$ & $\begin{array}{c}\text { Compliance } \\
\text { audit reports* }\end{array}$ & $\begin{array}{c}\text { Performance audit } \\
\text { reports }\end{array}$ & $\begin{array}{l}\text { Other reports } \\
\text { or documents }\end{array}$ & $\begin{array}{l}\text { Annual } \\
\text { activity } \\
\text { reports }\end{array}$ & $\begin{array}{l}\text { Reports at } \\
\text { request of } \\
\text { Parliament }\end{array}$ & Remarks \\
\hline Number submitted & 27 & & 18 & 24 & 1 & - & \\
\hline $\begin{array}{l}\text { Number discussed } \\
\text { by Parliament** }\end{array}$ & 27 & & 18 & 24 & 1 & - & \\
\hline $\begin{array}{c}\text { Submitted to } \\
\text { Speaker }\end{array}$ & 27 & - & 5 & - & - & - & \\
\hline $\begin{array}{l}\text { Submitted to Chair } \\
\text { of dedicated } \\
\text { committee }\end{array}$ & 27 & - & 18 & 24 & 1 & - & \\
\hline $\begin{array}{l}\text { Copied to other } \\
\text { relevant } \\
\text { committees }\end{array}$ & 1 & - & 4 & Not applicable & - & - & \\
\hline $\begin{array}{l}\text { Briefings organised } \\
\text { for parliamentary } \\
\text { committee }\end{array}$ & \multicolumn{7}{|c|}{47 (in total) } \\
\hline $\begin{array}{c}\text { Summaries } \\
\text { submitted to } \\
\text { Parliament }\end{array}$ & $2 * * *$ & - & 18 & 24 & 1 & - & \\
\hline \multicolumn{8}{|c|}{ Compliance audits are integrated in compliance-performance audits } \\
\hline ** SPIRK of the Par & ament & & & & & & \\
\hline
\end{tabular}

\section{3) Parliamentary procedures for SAI reports}

Currently there are no specific fixed procedures for handling of SAO of Latvia reports in the Parliament.

There is a specific committee for handling of SAO of Latvia reports, Committee for Public Expenditures and Audit, which is chaired by a suitable member. The procedure for selecting the candidate for the position of chair of the committee is based on political negotiations.

The committee does not appoint a rapporteur.

There are hearings held, in which auditees and other concerned persons are invited to provide clarification on the findings of the audit, as well as the progress of implementation of audit recommendations.

The committee can use independent external experts in examining reports if it deems necessary. It is common that the representatives of society, external organisations in the form of non-governmental 
organisations, are invited to share their opinion on the concerned audit. The committee may ask for additional information or clarification in writing from the responsible state officials.

The debate on SAO of Latvia reports is held only in the Committee for Public Expenditures and Audit.

As an outcome of a debate on an SAO's of Latvia report, the Parliament can acknowledge misconduct or imperfections (if any), and summon the representatives of the responsible auditee for further clarification of facts, as well as a call for certain actions to be taken.

The SAO of Latvia has no role in the discharge procedure utilised by the Parliament.

\section{Staffing}

According to the internal rulings, the support for the functioning of the Parliamentary committee is ensured by two consultants and a senior consultant. The support staff carries out in-depth research, analysis and provides briefings before the hearings. The support function also includes monitoring of the implementation of audit recommendations, and follow-up. If the terms for implementation of recommendations have been exceeded, written communication or on-site meetings with the representatives of the concerned auditees take place on the behalf of the Committee, organised by the support staff.

\section{SAl involvement in consideration of reports by Parliament}

The SAO of Latvia is involved in the process of the Committee's or Parliament's preparation for the hearings. The SAO of Latvia often hold meetings with the members of the Committee for Public Expenditures and Audit before the hearings, in order to start a discussion on the newest audit findings or audit reports which are soon to be submitted. The SAO of Latvia may be present during the meetings, hearings and raise awareness about its findings and issues discussed in the SAO of Latvia reports.

\section{4) SAI reports}

The SAO of Latvia focuses both on generic/systematic problems, as well as on identified isolated incidents. If during the audit internal control systems weaknesses are identified, then these are highlighted in the SAO of Latvia reports. Every report contains clear audit conclusions and audit opinions.

\section{5) Follow-up on SAI reports}

The SAO of Latvia regularly (every quarter of the year) communicates with the auditee to ensure that the audit recommendations are actually implemented. If the necessary actions are not carried out, then such issues are put forward to the Parliament. There is a system and a working process in place for implementation of audit recommendations.

The Parliament keeps track of the implementation process, ensuring follow-up through written and other forms of communication with the responsible auditees and other involved responsible bodies.

The SAO of Latvia issues a report on implementation/non-implementation of audit recommendations each half year in order to track the most current stage of progress. The audit recommendations are taken into account by the Ministry of Finance during the drafting of the annual national budget. 


\section{6) Audits on Parliament's request}

There are no such legal provisions. The SAO of Latvia is fully independent institution also in regards to its planning activities and the implementation of its audit plan. The Parliament does not ask the SAO of Latvia to carry out specific audits.

\section{7) Work programme}

The SAO of Latvia does not consult Parliament on its annual Work programme of audits. However the SAO of Latvia each year questions the Parliament about any relevant audit spheres of their interest. Such proposals are taken into account later on and evaluated when creating the annual audit plan.

\section{8) Level and frequency of contacts}

The SAO of Latvia co-ordinates the reporting timetable with the Committees of the Parliament. The meetings between the SAO of Latvia and Parliament take place on a regular basis. Additional meetings can be held due to some extraordinary findings of an audit, or other necessity in order to consult with the Parliament. Currently there is no specific staff in SAO of Latvia tasked with such relations.

\section{9) Good practice}

Recently the SAO of Latvia has interviewed the members of the Parliament on the budget system, in order to identify any issues that the Parliament is facing when working on budget related issues.

10) Perspective

Often the fundamentally significant audit findings are not discussed during the plenary sessions of the Parliament, and the feedback from the Parliament as whole is missing.

Another issue is the lack of communication by MPs of some of the political parties which are part of the Committee for Public Expenditures and Audit. Without proper reporting to the corresponding factions, the MPs who are not part of the Public Expenditure and Audit Committee may lack the full overview and scope of the current situation and findings by the SAO of Latvia.

11) Are there any other relevant features of the current relations between the SAI and Parliament that you would like to highlight, and how have they evolved over the past five years?

In the past five years the overall communication practice with the Committees of Parliament has seen further progress. The SAO of Latvia can address the responsible Committees of Parliament if significant misconduct is found in audits which are part of committee's fields of jurisdiction. 


\section{LITHUANIA}

National Audit Office

\section{1) Legal framework}

\section{The Constitution of the Republic of Lithuania}

The National Audit Office supervises the lawfulness of the possession and use of state-owned property and the execution of the State budget.

The Auditor General submits a conclusion to the Seimas (Lithuanian Parliament) about the report on the annual execution of the budget. (Article 134)

\section{Law on National Audit Office}

Financial audit of the National Audit Office shall be performed by an audit body appointed by the resolution of the Seimas. (Article 8)

The National Audit Office shall annually submit to the Seimas:

a) opinion and the audit report on the set of consolidated statements of the State;

b) opinion and the audit report on the set of consolidated statements of the Compulsory Health Insurance Fund;

c) opinion and the audit report on the set of consolidated statements of the State Social Insurance Fund;

d) opinion and the audit report on the sets of statements of state monetary funds the estimates of which are approved by the Seimas;

e) opinion and the audit report on the national set of financial statements which includes the public debt report;

f) annual report of the National Audit Office. (Article 9)

In order to efficiently perform its functions, the National Audit Office shall establish a scope of the public audit. The National Audit Office shall annually establish the scope of the public audit in public audit programmes. These programmes shall be confirmed by the Auditor General, upon having assessed recommendations given by the Seimas Audit Committee.

The Seimas may by its resolution assign the National Audit Office to perform public audit within the competence of the National Audit Office. (Article 14)

\section{2) SAI reporting practices}

\section{Seimas of the Republic of Lithuania Statute (the Seimas Statute)}

1. The Government shall prepare and, by 10 October, approve and submit to the Seimas the following sets of statements: 
a) a set of consolidated statements of the State comprising the report on implementation of the State budget and consolidated financial statements of the State;

b) a set of consolidated statements of the State Social Insurance Fund comprising the report on implementation of the budget of the State Social Insurance Fund and consolidated financial statements of the State Social Insurance Fund;

c) a set of consolidated statements of the Compulsory Health Insurance Fund comprising the report on implementation of the budget of the Compulsory Health Insurance Fund and consolidated financial statements of the Compulsory Health Insurance Fund;

d) annual sets of statements of other monetary funds of the State the estimates of which are approved by the Seimas, where such sets comprise reports on implementation of the budget and financial statements;

e) a national set of financial statements.

2. The Auditor General must, by 10 October, present to the Seimas an opinion and audit report on the sets of statements referred to in paragraph 1 of this Article.

3. Upon receipt of the opinion of the Auditor General referred to in paragraph 2 of this Article and drafts of resolutions of the Seimas presented by the Government regarding the approval of the sets of statements referred to in paragraph 1 of this Article, Government reports about the sets of statements referred to in paragraph 1 of this Article and additional reports of the Auditor General shall be heard at the next Seimas sittings.

4. Upon hearing of the reports referred to in paragraph 3 of this Article at the Seimas sittings, the committees shall consider the sets of reports referred to in paragraph 1 of this Article and prepare conclusions. (Article 225)

Heads of state institutions who are appointed by the Seimas or whose appointment is subject to approval of the Seimas shall submit (usually by March 1 ) an annual activity report of the institution. Upon receipt of such report, the Speaker of the Seimas shall notify the Seimas about this and the latter shall decide on the committee to be assigned with consideration of the submitted report. Having considered the report, the committee shall prepare a conclusion and a draft resolution to be debated at a Seimas sitting along with the report by the head of the state institution. The Seimas shall adopt a resolution about the head's report and institution's activities. (Article 206)

\section{Law on National Audit Office}

Auditor General shall no later than within five working days from processing public audit documents, submit performance audit reports and financial (regularity) audit reports and opinions to the Seimas Audit Committee, when National Audit Office officers issue qualified or adverse opinion, or disclaimer of opinion on financial accounts. (Article 10) 
SAl also submits:

- Report on the implementation of public audit recommendations.

- Other reports upon necessity and subjects that are prepared on the basis of separate audits and are of interest to the Seimas.

Usually audit reports are addressed to the Chair of dedicated committee (Audit Committee).

\section{Procedures for sending reports to Parliament}

Auditor General shall no later than within five working days from processing public audit documents, submit performance audit reports and financial (regularity) audit reports and opinions to the Seimas Audit Committee, when National Audit Office officers issue qualified or adverse opinion, or disclaimer of opinion on financial accounts. (Article 10 of Law on National Audit Office)

All the audit reports except the obligatory opinions and annual SAI activity report that are submitted directly to the Speaker of the Seimas, are submitted to the Committee on Audit. Usually the Committee on Audit prepares hearings on the reports during which the main audit findings are presented. In separate cases, a special consideration of audit results might be organised when an audited entity is invited to the Committee on Audit to discuss with the SAI the existing situation and the way forward. The Committee on Audit might adopt a decision according to the audit results which obligates the audited entity to carry out obligatory actions about the implementation of audit recommendations.

Separate considerations of audit reports are organised in select committees to which the reports are submitted by the Committee on Audit. Obligatory opinions submitted by the SAI are considered also in plenary. 
Number and type of reports

\begin{tabular}{|c|c|c|c|c|c|c|c|}
\hline & $\begin{array}{l}\text { Financial } \\
\text { audit } \\
\text { reports }\end{array}$ & $\begin{array}{l}\text { Compliance } \\
\text { audit reports }\end{array}$ & $\begin{array}{c}\text { Performance audit } \\
\text { reports }\end{array}$ & $\begin{array}{l}\text { Other reports } \\
\text { or documents }\end{array}$ & $\begin{array}{l}\text { Annual } \\
\text { activity } \\
\text { reports }\end{array}$ & $\begin{array}{l}\text { Reports at } \\
\text { request of } \\
\text { Parliament }\end{array}$ & Remarks \\
\hline Number submitted & 32 & - & 21 & 3 & 1 & - & $\begin{array}{c}\text { The SAI also } \\
\text { submitted } 8 \\
\text { obligatory } \\
\text { opinions }\end{array}$ \\
\hline $\begin{array}{l}\text { Number discussed } \\
\text { by Parliament }\end{array}$ & 13 & - & $27^{*}$ & 1 & 1 & - & 8 \\
\hline $\begin{array}{c}\text { Submitted to } \\
\text { Speaker }\end{array}$ & - & - & - & - & 1 & - & 8 \\
\hline $\begin{array}{l}\text { Submitted to Chair } \\
\text { of dedicated } \\
\text { committee }\end{array}$ & 23 & - & 20 & 3 & - & - & - \\
\hline $\begin{array}{l}\text { Copied to other } \\
\text { relevant } \\
\text { committees }\end{array}$ & 13 & - & 22 & - & - & - & - \\
\hline $\begin{array}{c}\text { Briefings** } \\
\text { organised for } \\
\text { Parliamentary } \\
\text { committee }\end{array}$ & 13 & - & 27 & 1 & - & - & - \\
\hline $\begin{array}{c}\text { Summaries*** } \\
\text { submitted to } \\
\text { Parliament }\end{array}$ & - & - & - & - & - & - & - \\
\hline
\end{tabular}

* 14 audits conducted in 2015, 13 audits from earlier years.

** When reports are discussed in the Parliament the National Audit Office representatives deliver presentations in respect of reports.

*** The SAl submits full reports to the Seimas and its committees. All our reports contain summaries.

\section{3) Parliamentary procedures for SAI reports}

The remit of the Committee on Audit shall be to consider public audit reports and opinions submitted by the National Audit Office to the Seimas and/or the Seimas Committees. (Article 591 of the Seimas Statute)

There is a dedicated committee that exists for handling SAI reports. It is chaired by a member of the government party/parties. In previous Seimas (2008-2012) it was chaired by a member of the opposition. This is based on political negotiations.

Presentations on public audit reports are usually made by SAI representative. 
There are hearings to which the auditee or other appropriate persons are invited to provide clarification or further information.

The debate on SAI reports is held in committee(s).

Other committees, apart from any dedicated committee, also consider the reports of the SAl (if other committee decides so after request of dedicated committee).

The decision of a committee can be produced as an outcome of a debate on a SAI report. The decision of a committee obliges the government, ministry or governmental agency to implement recommendations of SAI report and to inform the committee on the issue. The decision of a committee is published on its website, also Parliamentary press release can be issued.

\section{Staffing}

There is no special Parliamentary staff supporting the committee(s) dealing with SAI reports. Any employee of the committee can deal with SAI reports. The employee usually prepares short summary of SAI report, and develops some questions for the committee to ask. As it was mentioned already, a decision of committee or (and) Parliamentary press release can be issued.

\section{SAl involvement in consideration of reports by Parliament}

The SAI undertakes presentation of audit reports to a Parliamentary committee if the latter decides to consider it. Usually the Auditor General attends Parliamentary meetings of the Audit Committee when SAI reports are debated. Presentation of audit reports is made by the director of the SAI department responsible for the issue debated, also head of the audit group of the issue attends the meeting.

\section{4) SAl reports}

The SAI focus on generic/systemic problems and recommendations in its communications to Seimas.

It is especially relevant when considering performance audit reports that are aiming at systemic and strategic issues at national level and providing information to the Seimas. Twice a year the SAl prepares and submits to the Committee on Audit a report on the implementation of audit recommendations. The report highlights the most significant recommendations having the greatest impact on the audited areas of public governance that have remained unimplemented for a long time.

Based on these reports the Committee on Audit adopts decisions addressed to the Government, encouraging it to undertake efforts to ensure that the SAI recommendations are implemented. The Committee on Audit submits the report on the implementation of recommendations for consideration to select committees.

The set up and functioning of internal control systems can be a subject that is highlighted in SAI reports. Assessment of internal controls is especially important and relevant in financial (regularity) audits. In performance audit internal controls are assessed as much as it is required to achieve the audit aim. In the 2016 annual audit programme, the SAI is planning to conduct an audit that will deal with the implementation of an internal control system in the entire public sector, in order to reveal systemic problems and assist in their solution. 
All audit reports contain clear conclusions and recommendations. Financial (regularity) audit conclusion provides clear audit opinion.

\section{5) Follow-up on SAI reports}

The SAI monitors implementation of each audit report recommendations since 2008. The SAI keeps track of conclusions and recommendations accepted by auditees by using an internal information system. The system tracks the status of progress until implementation is complete. The system has recently been equipped with a new tool, which enables anyone from outside to check the status of implementation of each recommendation.

The Audit Committee pays attention to the implementation of SAl recommendations in audit reports, asking the SAI to report on that twice a year. The SAI reports specifically on the non-implementation of recommendations, including those in respect of the set up and functioning of internal control systems. In some cases this stimulates Parliamentary follow-up. Ministries and Governmental agencies are required to report on the implementation of SAI recommendations. SAI's opinion and audit report on a set of consolidated statements of the State (comprising the report on implementation of the State budget and consolidated financial statements of the State) and on a national set of financial statements are used as input for the annual debate on draft budgets.

\section{6) Audits on Parliament's request}

The Seimas may by its resolution assign the National Audit Office to perform public audit within the competence of the National Audit Office. (Article 14 of Law on National Audit Office)

In practice it is used in exceptional cases, usually once per year or less.

\section{7) Work programme}

The National Audit Office shall annually establish the scope of the public audit in Public Audit programmes. These programmes shall be confirmed by the Auditor General, upon having assessed recommendations given by the Seimas Audit Committee. (Article 14 of Law on National Audit Office)

In practice the Seimas Audit Committee gathers suggestions from all the Seimas committees and sends them to the SAI. Received information is taken into consideration when conducting strategic analysis and rating public sector risks observed by auditors preparing the annual audit programme.

\section{8) Level and frequency of contacts}

There is regular (almost weekly) contact (including informal) between the head of the SAI and the Chair of competent committee in Parliament.

SAI Legal and Personnel Department (Director of the Department and Adviser of Legal Division) is tasked with Parliamentary daily relations.

\section{9) Good practice}

There is bilateral consultation between the SAI and the Seimas Audit Committee, including separate consultation with its staff.

The SAI provides operational information relating to audit upon the requests of the members and Office of the Committee on Audit. 
The SAI expresses an opinion on the draft legal acts relating to the SAl activity, such as execution of national budget, management of public property, public procurement.

The SAI organises joint events like the presentation of the annual audit programme to the Committee on Audit and Chairs of other committees, and Head of Parliamentary factions. It also organises conferences on relevant issues like fiscal discipline).

\section{0) Perspective}

Sometimes members of the Seimas are not interested in SAI audit reports. This question is discussed in bilateral consultation in order to find ways to make presentations more interesting. However it is still long-term objective.

\section{1) Are there any other relevant features of the current relations between the SAI and Parliament that you would like to highlight, and how have they evolved over the past five years?}

The SAI considers the Seimas and the Committee on Audit its strategic partner in the strive to increase the impact of audit recommendations, therefore we pay special attention to maintaining professional relations, both formal and informal. Every time a new Parliament is elected and new Committee on Audit is being set up, the SAl organise meetings with its members, during which it explains the importance of the SAI mandate, peculiarities of performing public audit, and the impact of its results bringing positive changes in the public sector.

The SAI representatives take part in the hearings of the Committee on Audit, even in the cases when concrete audit reports are not considered. Appointed contact persons work with the Office of the Committee on Audit on continuous basis. SAl experts try to participate in all the sittings of Parliamentary committees and commissions which consider concrete issues related to audit results or systemic public sector problems.

SAl's Legal and Personnel Department continuously monitors information on the consideration of draft legal acts, and provide the auditors with the relevant information. If the draft legal act under consideration is relevant to the implementation of audit recommendations, in separate cases summarised information on audit results is provided repeatedly (e.g. In the case of preparation of the Law on Public Procurement) which, in our opinion, might be relevant when considering the draft law or its amendment. Joint conferences are organised with the Seimas Committee on Audit and other Parliamentary committees on mutually important issues to draw the attention of the Parliament and other institutions to systemic problems at national level. 


\section{LUXEMBOURG}

\section{Court of Auditors}

\section{1) Legal framework}

The Legal framework in respect to the SAl's obligations to Parliament are defined by the Loi modifiée du 8 juin 1999 portant organisation de la Cour des comptes.

The Constitution and the budget law do not contain any references to the SAl's obligations to Parliament.

According to Article 4 of this law, the SAI must inform the Parliament if it finds any fraudulent activities of the auditees.

Article 5 of the law states that the Court must send its special audit reports (together with a statement by the audited body) to the Parliament.

Article 6 states that the Parliament may ask the SAI to give an opinion on the draft State budget proposal. The Parliament may ask the SAI to give an opinion on planned legislation which will have a large impact on the State budget.

\section{2) SAI reporting practices}

The SAI of the Grand-Duchy of Luxembourg regularly presents special reports, which are a combination of financial and performance audits on a particular subject, to the Parliament.

Additionally, it sends annual reports, which group recurring financial audits of public institutions, to Parliament.

Finally, it presents its annual opinion on the draft state budget proposal, as well as its annual opinion on the Government accounts to Parliament.

It also submits its annual activity report to Parliament.

As stated, the special reports are about individual audits, while the annual reports group several recurring financial audits carried out on a regular basis.

The reports are addressed to the President of the Parliament.

There are no deadlines for the submission of reports to the Parliament.

\section{Procedures for sending reports to Parliament}

According to the rules of procedure of both the SAI and the Parliament, all reports must be submitted to the President of the Parliament.

The reports are presented orally to the relevant Parliamentary committee (by the responsible councillor/member of the Court). After the presentation, the report is sent to all Parliamentary members and made available to the public through the SAl's website. A press release follows the presentation. 
Number and type of reports

\begin{tabular}{|c|c|c|c|c|c|c|c|}
\hline & $\begin{array}{l}\text { Financial } \\
\text { audit } \\
\text { reports }\end{array}$ & $\begin{array}{l}\text { Compliance } \\
\text { audit reports }\end{array}$ & $\begin{array}{c}\text { Performance audit } \\
\text { reports }\end{array}$ & $\begin{array}{l}\text { Other reports } \\
\text { or documents }\end{array}$ & $\begin{array}{l}\text { Annual } \\
\text { activity } \\
\text { reports }\end{array}$ & $\begin{array}{l}\text { Reports at } \\
\text { request of } \\
\text { Parliament }\end{array}$ & Remarks \\
\hline Number submitted & \begin{tabular}{|c}
1 \\
(yearly \\
report \\
which \\
contains \\
financial \\
audits of 13 \\
different \\
public \\
bodies).
\end{tabular} & $\begin{array}{c}1 \text { (same as for } \\
\text { the financial } \\
\text { audits) }\end{array}$ & 1 & 2 & 1 & 0 & \\
\hline $\begin{array}{c}\text { Number discussed } \\
\text { by Parliament }\end{array}$ & 6 & & & & & & $\begin{array}{l}\text { This includes } \\
\text { reports } \\
\text { submitted in } \\
\text { the years } \\
\text { before } 2015 .\end{array}$ \\
\hline $\begin{array}{c}\text { Submitted to } \\
\text { Speaker }\end{array}$ & & & & & & & $\begin{array}{l}\text { All reports } \\
\text { are submitted } \\
\text { to the } \\
\text { President of } \\
\text { the } \\
\text { Parliament. }\end{array}$ \\
\hline $\begin{array}{l}\text { Submitted to Chair } \\
\text { of dedicated } \\
\text { committee }\end{array}$ & & & & & & & See above. \\
\hline $\begin{array}{l}\text { Copied to other } \\
\text { relevant } \\
\text { committees }\end{array}$ & & & & & & & \\
\hline $\begin{array}{l}\text { Briefings organised } \\
\text { for Parliamentary } \\
\text { committee }\end{array}$ & & & & & & & \\
\hline $\begin{array}{l}\text { Summaries } \\
\text { submitted to } \\
\text { Parliament }\end{array}$ & & & & & & & \\
\hline
\end{tabular}

3) Parliamentary procedures for SAI reports

The procedures are fixed in the Rules of procedure of the Parliament, which state that communication of the SAI's reports must be addressed to the President of the Parliament. 
There is no official committee for handling SAI reports, however in practice they are treated by the Control Committee on Budget Execution. It is chaired by a member of the opposition party, which is based on tradition.

The committee appoints rapporteurs for the SAl's reports.

There are hearings held to which the auditee, responsible minister or other appropriate persons, and members of the SAl, may be invited to provide clarification.

There are no fixed procedures on independent external experts, and generally there is no use of external experts, except if the committee decides to further explore the issue. They may then command an independent audit by external experts.

The debate on SAI reports is held in the committee.

Other committees generally do not consider the reports of the SAI.

\section{Staffing}

There is one member of the administrative staff responsible for SAI reports. Their main task is to draft reports of committee hearings. However, they may be asked to provide research in preparation for debates.

\section{SAI involvement in consideration of reports by Parliament}

The SAl is not involved in the committee's preparation for hearings.

The responsible member of the Court attends Parliamentary meetings to present the report, and may attend when the report is debated. They may answer questions and provide further clarification on the reports.

\section{4) SAI reports}

The SAI, among other issues, focuses on systemic risks in the reports submitted to Parliament. The internal control system is always highlighted in SAI reports, and usually is one of the main focal points. All audit reports contain clear conclusions and recommendations.

\section{5) Follow-up on SAI reports}

The SAI keeps track informally of conclusions and recommendations accepted by auditees. It may carry out follow-up audits.

The Parliament debates the implementation of SAI recommendations and follows up on them in its hearings.

\section{6) Audits on Parliament's request}

According to the law cited above, the Parliament may request audits from the SAI. In practice, the Parliament requests such audits about every two years. 


\section{7) Work programme}

The SAI does not consult Parliament on its Work programme, in order to safeguard the independence of the SAI.

8) Level and frequency of contacts

There is regular contact between the Parliament and the SAI. The Parliament keeps the SAI updated on its activities by e-mail, generally on a weekly basis.

In practice one person is responsible for the relations with the Parliament. 


\section{MALTA}

National Audit Office

\section{1) Legal framework}

The Maltese Constitution stipulates that the accounts of all departments and offices of the Government of Malta and other public authorities or bodies making use of public funds are to be audited and reported upon annually by the Auditor General (AG) to the House of Representatives. The Auditor General and National Audit Office Act (Chapter 396 of the Laws of Malta) states that the annual audit report on the public accounts (which comprises compliance audits and financial audits, including audits on the Government financial report statements) is to be submitted to the Speaker of the House of Representatives by not later than 12 months after the end of the financial year being reported upon, and the Speaker lays each report before the House of Representatives on the next sitting of the House after it is received.

Local audit legislation also specifies that the AG may make special reports to the House of Representatives on any matter of pressing importance or urgency, or dealing with value for money audit through the Speaker. The Speaker lays each report before the House on the next sitting after he receives the report.

State audit law also allows the AG to inquire, either personally or through the National Audit Office (NAO) Malta, and report upon anything relating to government finances, property or funds administered by Government ministries, departments and entities. The AG may also inquire into the operations of companies or other entities in which the Government of Malta owns not less than $51 \%$ of the shares, as well as on any other matter as may be provided by or under any law. These special reports, presented to the Speaker of the House of Representatives on the next sitting of the House, are prepared either on the $A G$ 's initiative, or at the request of the Minister responsible for finance. At least three members of the Public Accounts Committee (PAC) may also request a special report. The PAC is the standing Parliamentary committee tasked with reviewing the NAO's reports and taking evidence from auditees. In considering requests made by Parliament, the AG is not strictly obliged to carry them out (though it would be expected to do so).

The Act also stipulates that each audit report presented shall call attention to anything that the AG considers to be of significance and of a nature that should be brought to the attention of the House of Representatives. This includes lack of proper records, insufficient rules and procedures to safeguard public property, ineffective checks on the assessment, collection and allocation of revenues, unauthorised expenditure, instances where public monies have been expended uneconomically, inefficiently or ineffectively, and lack of satisfactory procedures to measure and report on the effectiveness of expenditure programmes.

State audit law further requires the AG to report annually to the House of Representatives on the work and activities of NAO Malta, and whether in carrying out his work he received all the information and explanations required. The annual NAO Malta work and activities report is submitted to the Speaker of the House of Representatives no later than 12 months after the end of the financial year being reported upon, and the Speaker lays each report before the House of Representatives on the next sitting of the House after it is received. 
The Legal framework does not require NAO Malta to communicate its work plan to Parliament or to other stakeholders.

\section{2) SAI reporting practices}

NAO Malta sends to Parliament its financial and compliance audit reports, performance audit reports, special audits and investigations reports, IT audit reports, as well as a report on its work and activities for each year. For financial and compliance audits, the results from several audits are combined in one report, referred to as the annual Report of the AG. For performance audits, special audits and investigations, as well as IT Audits, NAO Malta reports separately on individual audits. The report on NAO Malta work and activities is prepared annually and covers the work and activities of the preceding year.

All reports are addressed to the Speaker of the House of Representatives who then presents the reports to the House at its next sitting. Audit reports may also be taken up by the PAC.

As indicated previously, standing legislation stipulates that the report of the AG, as well as the NAO Malta work and activities report, are to be prepared annually, and submitted to the Speaker of the House of Representatives by not later than 12 months after the end of the financial year being reported upon.

Performance audit reports, special audits and investigations reports, and IT audit reports are submitted to the Speaker of the House of Representatives once completed.

\section{Procedures for sending reports to Parliament}

Each report prepared by the AG is presented to the Speaker of the House of Representatives. To aid understanding, each audit report contains an Executive Summary which outlines the salient objectives and results of the particular audit report. Each audit report is accompanied by a press release, which provides a summary of the main issues and findings included in the report.

NAO Malta's audit reports may also be reviewed by the PAC. The latter examines in detail audit reports prepared by the AG and holds hearings on these reports. Senior officials of the audited entities are invited to participate in these PAC meetings, to provide any information or explanations that may be required by the Committee. In this way the PAC ensures that NAO Malta's findings and recommendations are given due attention.

The AG takes an active role during the Committee's sittings by replying to any questions that may be made by members of the Committee. Other members of his staff who were involved in the audit assist as may be required. 
Number and type of reports

\begin{tabular}{|c|c|c|c|c|c|c|c|}
\hline & $\begin{array}{c}\text { Financial } \\
\text { audit } \\
\text { reports }\end{array}$ & $\begin{array}{l}\text { Compliance } \\
\text { audit reports }\end{array}$ & $\begin{array}{c}\text { Performance audit } \\
\text { reports }\end{array}$ & $\begin{array}{l}\text { Other reports } \\
\text { or documents }\end{array}$ & $\begin{array}{l}\text { Annual } \\
\text { activity } \\
\text { reports }\end{array}$ & $\begin{array}{l}\text { Reports at } \\
\text { request of } \\
\text { Parliament }\end{array}$ & Remarks \\
\hline Number submitted & $1^{*}$ & $1^{*}$ & 3 & 4 & 1 & 5 & $\begin{array}{c}\text { Reports at } \\
\text { the request } \\
\text { of Parliament } \\
\text { are special } \\
\text { audits and } \\
\text { investigations } \\
\text { reports. } \\
\text { Other reports } \\
\text { constitute } \\
\text { other two } \\
\text { special audits } \\
\text { and } \\
\text { investigations } \\
\text { reports as } \\
\text { well as two IT } \\
\text { audit reports. } \\
\text { *There is one } \\
\text { annual audit } \\
\text { report which } \\
\text { comprises } \\
\text { both financial } \\
\text { and } \\
\text { compliance } \\
\text { audits. }\end{array}$ \\
\hline $\begin{array}{c}\text { Number discussed } \\
\text { by Parliament }\end{array}$ & 1 & 1 & Nil & Nil & $\mathrm{Nil}$ & $\mathrm{Nil}$ & \begin{tabular}{|} 
The audit \\
reports \\
discussed by \\
the PAC \\
during 2015 \\
related to \\
reports \\
issued in \\
previous \\
years. The \\
Committee \\
also \\
scrutinised a \\
contract \\
entered into \\
by the \\
Government. \\
The financial \\
and \\
compliance \\
audit report
\end{tabular} \\
\hline
\end{tabular}




\begin{tabular}{|c|c|c|c|c|c|c|c|}
\hline & & & & & & & $\begin{array}{c}\text { issued in } \\
2015 \text { is being } \\
\text { reviewed by } \\
\text { the PAC in } \\
2016 .\end{array}$ \\
\hline $\begin{array}{c}\text { Submitted to } \\
\text { Speaker }\end{array}$ & $Y$ & $Y$ & $\mathrm{Y}$ & $Y$ & $\mathrm{Y}$ & $Y$ & \\
\hline $\begin{array}{c}\text { Submitted to Chair } \\
\text { of dedicated } \\
\text { committee }\end{array}$ & $Y$ & $Y$ & $Y$ & $Y$ & $Y$ & $Y$ & \\
\hline $\begin{array}{c}\text { Copied to other } \\
\text { relevant } \\
\text { committees }\end{array}$ & $\mathrm{N}$ & $\mathrm{N}$ & $\mathrm{N}$ & $\mathrm{N}$ & $\mathrm{N}$ & $\mathrm{N}$ & \\
\hline $\begin{array}{c}\text { Briefings organised } \\
\text { for Parliamentary } \\
\text { committee }\end{array}$ & $\mathrm{N}$ & $\mathrm{N}$ & $\mathrm{N}$ & $\mathrm{N}$ & $\mathrm{N}$ & $\mathrm{N}$ & \\
\hline $\begin{array}{l}\text { Summaries } \\
\text { submitted to } \\
\text { Parliament }\end{array}$ & $Y$ & $Y$ & $Y$ & $Y$ & $Y$ & $Y$ & \begin{tabular}{|c} 
Reports \\
including \\
executive \\
summaries \\
are submitted \\
to all \\
Parliamentary \\
members.
\end{tabular} \\
\hline
\end{tabular}

3) Parliamentary procedures for SAI reports

Standing Order 120E of the House of Representatives deals with the powers and composition of the PAC. Its powers include, inter alia, to inquire into matters related to public accounts referred to it by the House of Representatives, a Minister or the AG, and into public expenditure, as well as to examine reports and related documents, drawn up by the AG. The PAC consists of seven members, four from the Government side and three from the Opposition side. The Chair of the Committee is a senior member of the Opposition and is nominated by the Leader of the Opposition, after consultation with the Leader of the House of Representatives.

NAO Malta reports are not debated in Parliamentary plenary sessions, but during PAC meetings. The PAC may scrutinise NAO Malta reports submitted to the House of Representatives during its sittings. It is has the power to ask for evidence from senior officials of Ministries and Departments, or other public entities such as Permanent Secretaries and Heads of Departments. The AG attends PAC sittings and takes an active role in the proceedings.

It is not the practice for other Parliamentary committees to review NAO Malta reports, though they are not precluded from doing so. 
As indicated earlier, the Committee, through at least three of its members, may also request the AG to carry out investigations and other enquiries relating to matters within NAO Malta's mandate.

The PAC does not appoint rapporteurs, and does not employ experts. However, members from the media may attend the PAC sessions. Transcripts and minutes of PAC meetings are prepared and uploaded on the PAC website, while the sessions are streamed on the same website.

Usually the published debates are taken to be the official Committee reports. Recently however, one research analyst has been assisting the PAC clerk in drafting PAC reports.

Parliament does not have a fixed procedure for discharge, but PAC may request NAO Malta to carry out follow-ups of NAO Malta reports previously discussed by the Committee.

\section{Staffing}

The only employee is the PAC clerk, whose role is to co-ordinate meetings, issue agenda, take minutes, edit and publish transcripts of debates, follow-up any requests made by members during a particular meeting, and update the PAC page on Parliament's website. An extract about the activities of the Committee is incorporated in Parliament's annual report.

The Committee has recently decided that, when PAC is not discussing an NAO Malta report, where recommendations have already been made, then the Committee will issue a report with its own recommendations.

\section{SAI involvement in consideration of reports by Parliament}

NAO staff, especially those who had worked on the particular audit under scrutiny, are ready to provide the background information deemed necessary by the PAC if and when so required.

The AG, his Deputy, and other senior members of his staff, as well as the audit teams involved in carrying out the respective audits, attend Parliamentary meetings when SAI audit reports are debated. They take an active part by responding to queries from PAC members about the audit report under scrutiny by the Committee.

\section{4) SAI reports}

NAO Malta focuses mainly on generic/systemic problems and recommendations in its communications to Parliament. However, material errors which are not systemic are also reported to Parliament.

The set up and functioning of internal controls systems is a subject that is highlighted in SAI reports.

All audit reports contain clear conclusions and audit opinions.

\section{5) Follow-up on SAI reports}

The primary purpose of audit reports' follow-up is to provide the House of Representatives with timely information on an audited entity's progress towards addressing deficiencies noted in audit reports. Follow-up (in particular, for financial and compliance audits) includes: 
- a timely and systematic review of management action on audit recommendations made by NAO Malta and commitments that the Head of Department agreed to honour/undertake during PAC hearings;

- an assessment of whether the action has corrected or will likely correct the problems identified during the audit;

- an assessment of whether recommendations in original report have been addressed;

- a report comprising the results of the follow-up; and

- a careful determination as to whether any additional work should be carried out as a further follow-up or as a subsequent audit.

As a minimum, audit reports are followed up when the:

- issues in question are of a recurring nature;

- particular issue concerns a very serious irregularity; or

- the PAC requests progress or submits recommendations to an issue.

Issues may be followed up until NAO Malta is satisfied that the causes of deficiencies are being suitably addressed. The continuing applicability of the original recommendations is also considered.

NAO Malta keeps track of conclusions and recommendations accepted by auditees by reporting on auditee acceptance or otherwise of conclusions and recommendations in the audit report.

Parliament pays attention to the implementation of SAI recommendations in audit reports by enquiring of audited entities as to whether SAI recommendations have been implemented. If they have not, the entity is asked to provide a timeframe for implementation.

When conducting follow-up processes, the SAI reports specifically on the implementation/nonimplementation of recommendations, including those in respect of the set up and functioning of internal control systems. Follow-ups are carried out on the SAl's initiative or when requested by PAC. The PAC does not conduct its own follow-ups.

The Government is not required to report on the implementation of SAI recommendations. SAI reports are not regularly used as input for the annual debate on draft budgets.

\section{6) Audits on Parliament's request}

The law states that the AG may at the request of at least three (out of the seven) members of the PAC, inquire into and report on:

I. any matter relating to government finances, property or funds administered or under the control of any government department or office or of any body whose accounts are subject to his audit;

II. such accounts and financial reports which are in virtue of or under any law laid before the House of Representatives;

III. the accounts of those public authorities or bodies administering, holding or using funds belonging directly or indirectly to the Government of Malta; 
IV. the operations of companies or other entities in which the Government of Malta owns not less than 51 per cent of the shares;

V. any other matter as may be provided by or under any law.

In practice, members of the PAC request audits due to alleged infringement of government policies and regulations, as well as other established procedures; alleged mismanagement and misconduct; alleged inefficient and ineffective use of resources; or alleged abuse of authority. For instance, in 2015, five special audits and investigation reports were published following requests by this Committee for an investigation on certain central Government ministries and departments, as well as public entities.

NAO Malta has set up a specific section to handle special audits and investigations. Due to its independence, NAO Malta may refrain from carrying out a PAC request for an investigation. In practice, priority is given by the special audits and investigations section to investigations requested by the PAC. Due professional care and compliance with ethical requirements, including confidentiality, are exercised when carrying out all audits, including special audits and investigations.

\section{7) Work programme}

The SAI does not consult Parliament (Parliamentary committees, the Speaker of Parliament and other Parliamentary bodies) on its (multi-) annual Work programme of audits.

\section{8) Level and frequency of contacts}

Meetings between NAO Malta and the PAC to discuss the programme for PAC sittings for the particular year are held once or twice a year. Other ad hoc meetings relating to the PAC may be held as required.

There are no day to day meetings at working level.

SAI and Parliamentary relations are managed on an ad hoc basis.

\section{9) Good practice}

The relationship between NAO Malta and the PAC is collaborative, without in any way impairing NAO Malta independence.

Three members of the PAC may request NAO Malta to carry out special audits and investigations. In the past few years, such requests for investigations were fairly frequent, and this led to investigations of major government projects and entities. The results of some of these special audits and investigations were discussed extensively by the PAC.

When a Member of Parliament who is a PAC member has a conflict of interest with respect to the audit report being discussed during a PAC Sitting, he is replaced by another Member of Parliament.

The powers and functions of the PAC as set out in legislation and Standing Orders of Parliament were intended to bring NAO Malta into a closer relationship with the PAC.

\section{0) Perspective}

The PAC does not review and hold sittings on all NAO Malta reports.

A more structured/harmonised approach to PAC review of NAO Malta reports is to be encouraged. 
It is also felt that PAC Malta does not possess sufficient organisational capacity and appropriate resources, training and access to relevant expert advice, to optimally carry out the above duties.

11) Are there any other relevant features of the current relations between the SAI and Parliament that you would like to highlight, and how have they evolved over the past five years?

NAO Malta and the PAC have a collaborative relationship. A number of NAO Malta audit reports are reviewed by the PAC.

One major special audit and investigation on fuel procurement was discussed extensively by the PAC. As a result, a number of other NAO Malta audit reports could not be effectively discussed. NAO Malta thinks that the Committee agenda, while dedicating more sittings to serious findings of NAO Malta audit reports, should ensure that all NAO Malta Audit Reports are discussed within a reasonable timeframe.

Other issues affecting public funds, such as on a number of contracts/agreements entered into by the Government as well as Central Bank monetary policy, were discussed during the PAC sessions.

Since Malta is an EU member, the annual audit report on the EU budget prepared by the European Court of Auditors, as well as the work of the Maltese Member of the Court are discussed by the PAC.

NAO Malta attends all PAC sittings, even those that do not deal with the review of its audit reports. 


\section{MONTENEGRO}

State Audit Institution

\section{1) Legal framework}

Constitution of Montenegro, Article 144: The State audit institution shall submit an annual report to the Parliament.

Law on State audit institution, Article 6: When adopting the budget of Montenegro and the final budget accounts of Montenegro, the Institution shall submit to the Parliament of Montenegro the overview of its findings on the budget and state of property, pointing out the causes and consequences of any major errors and irregularities and proposing measures for their elimination.

Law on State audit institution, Article 15: The Institution shall report to the Parliament and the Government, as a rule, after the audited entity has expressed its opinion on the findings of the audit. The Institution may report to the Parliament or the Government, prior to the audited entity having expressed its opinion, in cases where a delayed submission of the report would cause damage, or the findings are prematurely disclosed to the public, or if the audited entity has not expressed its opinion within due time.

Law on State audit institution, Article 18: The Institution shall report to the Parliament and the Government: 1 ) by submitting the annual report; 2) by submitting special reports; 3 ) by giving advice based on the findings gained through the audit.

Law on State audit institution, Article 19: The annual report shall be submitted to the Parliament and the Government by the end of October. The President of Montenegro, the President of the Parliament and the Prime Minister shall be informed about circumstances of confidential nature, which have caused or may cause financial or other damage of larger extent.

Law on State audit institution, Article 20: The Institution shall inform the Parliament and the Government on particularly important issues through special reports.

Law on State audit institution, Article 21: Based on the findings gained through the audit, the Institution may advise the Parliament and the Government on financially significant measures and important projects. The Institution, in case it has found out that the existing laws produce or may produce negative consequences, or that they do not lead to expected results, may give recommendations for their amendment.

Law on State audit institution, Article 22: The Institution shall inform the Parliament and the Government the reasons for withdrawing the claim for damages.

Law on State audit institution, Article 26: During the procedure of adoption of the final budget accounts of Montenegro, the Institution shall report to the Parliament on the audit of the final budget accounts. On the basis of essential facts and circumstances pointed out in the annual report of the Institution, the Parliament shall decide on proposed measures and time limit for their implementation. The Parliament may request from the Institution additional clarification of specific facts and circumstances.

Law on Budget and Fiscal Responsibility, Article 26: The State Audit Institution shall assess the application of the fiscal responsibility criteria as part of the annual report submitted to the Parliament. Based on the 
assessment of the State Audit Institution, the Ministry of Finance shall propose to the Government, and the Government shall propose to the Parliament, a plan for recovery of numeric limits being exceeded, in accordance with this law.

Law on Budget and Fiscal Responsibility, Article 67: The Government shall adopt the proposal of the law on the year-end accounts of the State budget by the end of June and shall submit it to the State Audit Institution, which shall submit a report on the audit of the year-end accounts of the budget to the Parliament by 15 October of the current for the previous fiscal year.

\section{2) SAI reporting practices}

The State audit institution (SAI) submits to the Parliament the audit report on the State budget execution and annual audit report of the SAI, which contains in particular: audit report on the State budget execution; report on assessment of the fiscal responsibility criteria, report on implementation of the recommendations from the audit report on the State budget execution of the previous fiscal year; summaries of the final individual audit reports with key findings and recommendations, as well as a review on the other activities of the SAI (co-operation with the Parliament, international co-operation, implementation of the strategic development plan, human resources, training, implementation of projects, implementation of EU recommendations in view of the accession negotiation with Montenegro etc.).

The SAI submits to the Parliamentary committees the individual financial, regularity and performance audit reports if the Auditing Board finds it essential and it states this in the individual audit reports.

The SAI submits its financial reports on an annual basis, when the Senate submits a draft budget of the Institution to the competent parliamentary committee in charge of finances.

\section{Procedures for sending reports to Parliament}

There are no written procedures for the SAI to send reports to Parliament.

The President of the SAI participates at the session of the Parliamentary Committee on Economy, Finance and Budget during the debate on audit report on state budget execution. The President of the SAI, with a member of Senate, also takes part in the plenary session during the presentation of the annual audit report of the institution.

For the individual audit reports, the Auditing Board for a given audit may participate at the session of the competent Parliamentary committees during the debate on given audit report. 
Number and type of reports

\begin{tabular}{|c|c|c|c|c|c|c|c|}
\hline & $\begin{array}{l}\text { Financial } \\
\text { audit } \\
\text { reports }\end{array}$ & $\begin{array}{l}\text { Compliance } \\
\text { audit reports }\end{array}$ & $\begin{array}{c}\text { Performance audit } \\
\text { reports }\end{array}$ & $\begin{array}{l}\text { Other reports } \\
\text { or documents }\end{array}$ & $\begin{array}{l}\text { Annual } \\
\text { activity } \\
\text { reports }\end{array}$ & $\begin{array}{l}\text { Reports at } \\
\text { request of } \\
\text { Parliament }\end{array}$ & Remarks \\
\hline Number submitted & 6 & $6^{38}$ & 3 & 1 & 1 & & \\
\hline $\begin{array}{c}\text { Number discussed } \\
\text { by Parliament }\end{array}$ & 6 & 6 & 3 & 1 & $1^{39}$ & & \\
\hline $\begin{array}{l}\text { Submitted to } \\
\text { Speaker }\end{array}$ & $\mathrm{N}^{40}$ & $\mathrm{~N}$ & $\mathrm{~N}$ & $Y^{41}$ & $\bar{Y}$ & & \\
\hline $\begin{array}{c}\text { Submitted to Chair } \\
\text { of dedicated } \\
\text { committee }\end{array}$ & $\mathrm{Y}$ & $Y$ & $Y$ & $Y$ & $Y$ & & \\
\hline $\begin{array}{c}\text { Copied to other } \\
\text { relevant } \\
\text { committees }\end{array}$ & $\mathrm{N}$ & $\mathrm{N}$ & $\bar{Y}$ & $\mathrm{~N}$ & $\mathrm{~N}$ & & \\
\hline $\begin{array}{l}\text { Briefings organised } \\
\text { for Parliamentary } \\
\text { committee }\end{array}$ & $\mathrm{N}$ & $\mathrm{N}$ & $\mathrm{N}$ & $\mathrm{N}$ & $\mathrm{N}$ & & \\
\hline $\begin{array}{l}\text { Summaries } \\
\text { submitted to } \\
\text { Parliament }\end{array}$ & $\mathrm{N}$ & $\mathrm{N}$ & $\mathrm{N}$ & $\mathrm{N}$ & $\mathrm{N}$ & & \\
\hline
\end{tabular}

\section{3) Parliamentary procedures for SAI reports}

Parliament's Rules of Procedure does not prescribe the procedure for handling SAI reports. The Parliamentary committees use the SAI audit reports as input for holding consultations, hearings and other thematic discussions.

Parliament's Rules of Procedures does not prescribe a special Parliamentary committee whose only obligation is to handle SAl audit reports. The Committee on Economy, Finance and Budget is mainly in charge of handling SAI reports.

The Committee on Economy, Finance and Budget is chaired by a MP of the Parliamentary minority. This is an established practice.

\footnotetext{
Compliance audit is performed as part of financial audit.

39 The annual audit report consists of summaries of the all audits performed from October in the previous year to October in the current year.

40 From six financial (compliance) audits, the SAI submitted to the Speaker of the Parliament one audit report on state budget execution.

41 This refers to the report on assessment of the implementation of the fiscal responsibility criteria, which is a integral part of the annual audit report.
} 
Parliament's Rules of Procedures envisages a possibility for the Committee to use independent professional experts. The Committee can ask for additional information related to a specific theme from those who participate in the session. This is usually used when the Committee organises hearings. The support staff of the Committee analyse submitted material and information, and deliver it to the members of Committee for information.

The auditee and other appropriate persons are invited to the hearing to provide clarification or further information.

The debate on SAI reports is held both in committee(s) and plenary.

The other committees apart from the Committee on Economy, Finance and Budget also consider the SAI individual reports if they cover the issues within their competence (for example the audit report on Ministry of Defence was discussed at the Parliamentary Committee on Security and Defence).

Parliament produces a report (minutes) or conclusion on its debate. These reports (minutes) and conclusions are published on the Parliament's website. Parliament adopts the conclusions which contain the key recommendations from the audit report on state budget execution, and the conclusions are published in the Official Gazette of Montenegro. These conclusions are proposed by the Parliamentary Committee on Economy, Finance and Budget, and Parliament adopts them in the form of its own conclusions.

\section{Staffing}

The members of the Parliamentary Committee on Economy, Finance and Budget are supported by the Secretariat of the Committee. Currently, there are five senior advisers within the Secretariat.

The Secretariat of the Committee is responsible for providing briefings, analyses, and draft conclusions of the committee's review of SAl's reports. Apart from analyses of draft laws, the Secretariat is responsible for providing analyses of the SAl audit of state budget execution, shorter analyses of the SAI annual report on performed audits, and summaries on implementation of the Parliamentary conclusions related to recommendations given in the previous audit of the State budget execution.

\section{SAl involvement in consideration of reports by Parliament}

The President, accompanied by relevant member of Senate or head of audit department, attends Parliamentary meetings when SAI reports are debated, and presents key audit findings and recommendations from given audit reports. The SAI may provide additional inputs to the Parliament committees before and after the hearings.

\section{4) SAI reports}

Financial and regularity audit reports deal with the functioning of internal control systems of the auditees, and this area is clearly highlighted in the SAI reports.

Since the SAI usually performs combined financial and regularity audit within one audit report, it gives two audit opinions, one related to the financial statements, and another on compliance with the prescribed criteria, laws, and bylaws).

If the regularity audit is performed as an individual audit, the SAI also gives clear audit opinion. 
All audit reports contain clear conclusions.

\section{5) Follow-up on SAI reports}

The SAI keeps records of conclusions and recommendations to the auditees. These are kept in a word/excel file.

For the recommendations given in the audit report on state budget execution, the SAl submits to Parliament a report on implementation of the recommendations given in the previous fiscal year. The mechanism to follow up the implementation of the recommendations related to the audit on state budget execution exists and functions well within the SAI. Since these recommendations are included in the form of the Parliamentary conclusions (published in the Official Gazette of Montenegro), the Parliamentary Committee on Economy, Finance and Budget easily follows up implementation of the recommendations.

The Parliament demanded from Government an action plan to act on the recommendations of the SAI, and to report back to Parliament on the implementation. This included the establishment of a coordinating team of ministers and heads of State bodies to monitor the implementation of the action plan. The audited entities covered by the audit report on state budget execution provide reports on implementation of given recommendations, and the Government prepares quarterly reports to Parliament.

If the Parliamentary Committee on Economy, Finance and Budget holds a hearing, it usually adopts its conclusion, based on which the auditee(s) provide(s) the report on implementation of the recommendations.

This follow-up mechanism also functions well for the follow-up of the implementation of recommendations in the audit reports on annual consolidated financial statements of the political parties, which are carried out each fiscal year.

For individual audit reports, the Law on SAI prescribes that the audited entity is obliged to submit its report on implementation of the recommendations given in the audit report within the time frame set by the SAl. The audited entities regularly submit their reports. The Leader of the Auditing Board may request the State auditor to check the accuracy of the information provided in the report on the implementation of audit recommendations, and to draft a separate audit minute. If the audited entity has not acted on the recommendations given in the audit report, the Leader of the competent Auditing Board: 1) for partly implemented audit recommendations, or audit recommendations of less significance, may set a new deadline for their implementation; 2) for large numbers of unimplemented or partly implemented audit recommendations, or recommendations of higher importance, may propose a follow-up audit is included in the annual audit of the SAI.

The SAI's reports are usually used for debate during plenary sessions, especially for auditees with adverse or qualified audit opinion.

\section{6) Audits on Parliament's request}

The Law on SAI states that it will decide independently about the audited entities, including the subject, scope and type of audit, and the time and method of auditing, unless otherwise provided by this Law. The SAI has the obligation to audit the final budget accounts of Montenegro once a year. The Law on Budget and Fiscal Responsibility sets out an obligation to the SAI to conduct assessment of the implementation of 
the fiscal responsibility criteria. The Law on financing political parties sets out an obligation to the SAI to conduct an audit of the annual financial statements of the political parties which have income higher than $€ 10.000$.

There is no legal provision for Parliament to request audits.

The Parliamentary Committee on Economy, Finance and Budget expresses its opinion during a debate on the need to carry out audits on specific subjects. The Senate of the SAI takes into account their opinions, and in some cases the SAI has included such audits in the annual audit plan.

\section{7) Work programme}

The Senate adopts the annual audit plan by the end of the current year for the following year. The procedure related to drafting the annual audit plan is clearly set out in the instruction on methodology for financial and regularity audit.

The procedure of proposing and selecting of audits for the annual audit plan of the SAI is based on various criteria. These include whether the entity was audited in the previous period, the amount of public resources used by the entity, the results of previous audits and the level of implementation of audit recommendations. Information on work of the audit entity from Parliament, the Government or other state authorities, local self-government units and other entities indicates the need to control the audit entity, as does information from other sources, such as public information, civil sector, and letters from the public. Significance of the audit theme from the perspective of public interest is al;so considered.

The annual audit plan is a business secret of the SAI, but entities are notified of the audit commencement.

\section{8) Level and frequency of contacts}

The Senate of the SAI has a regular contact at working level with the Chair of Parliamentary Committee on Economy, Finance and Budget. There is a SAl unit tasked with international co-operation and relations with Parliament, Government and media. There is a regular contact between the SAl staff and support staff of the Parliamentary Committee on Economy, Finance and Budget.

The frequency of these contacts depends on the needs of the SAI and Parliament.

\section{9) Good practice}

Parliament adopts the recommendations given in the audit on state budget execution in the form of its own conclusions. The Parliamentary conclusions are published in the Official Gazette of Montenegro.

\section{0) Perspective}

There is a lack of written procedures for dealing with the audit reports.

There is a lack of a mechanism to follow up the implementation of audit recommendations given in the individual audit reports. 
POLAND

Supreme Audit Office

\section{1) Legal framework}

The SAl's obligations to Parliament (e.g. communication on the SAl's work plan, the SAI's reporting obligations, and the need to consider audits requested by Parliament) are set out in the Constitution of the Republic of Poland and the Supreme Audit Office Act of 23 December 1994.

\section{2) SAI reporting practices}

The SAI (NIK) submits to Parliament the following reports: financial audit reports (6 in 2015), compliance audit reports (39 in 2015), performance audit reports (87 in 2015), reports on the State budget execution of various budget parts (92 in 2015), analyses of the State budget execution in the previous year ( 1 in 2015) and an annual activity report (1 in 2015).

\section{Procedures for sending reports to Parliament}

The annual activity report of NIK and the annual work plan are presented to the State Audit Committee for approval, after discussion. Audit results are submitted to Parliament. 
Number and type of reports

\begin{tabular}{|c|c|c|c|c|c|c|c|}
\hline & $\begin{array}{l}\text { Financial } \\
\text { audit } \\
\text { reports }\end{array}$ & $\begin{array}{l}\text { Compliance } \\
\text { audit reports }\end{array}$ & $\begin{array}{l}\text { Performance } \\
\text { audit reports }\end{array}$ & $\begin{array}{l}\text { Other reports } \\
\text { or documents }\end{array}$ & $\begin{array}{l}\text { Annual } \\
\text { activity } \\
\text { reports }\end{array}$ & $\begin{array}{l}\text { Reports at } \\
\text { request of } \\
\text { Parliament }\end{array}$ & Remarks \\
\hline $\begin{array}{l}\text { Number } \\
\text { submitted }\end{array}$ & 6 & 39 & 87 & \begin{tabular}{|c|}
92 \\
(state budget \\
execution of \\
various budget \\
parts) \\
1 \\
(analysis of the \\
State budget \\
execution in \\
the year)
\end{tabular} & 1 & Not applicable & \\
\hline $\begin{array}{c}\text { Number discussed } \\
\text { by Parliament }\end{array}$ & & & 59 & 86 & 1 & & $\begin{array}{l}\text { In total the } \\
\text { Parliament and its } \\
\text { commissions } \\
\text { discussed } 146 \text { NIK } \\
\text { reports }\end{array}$ \\
\hline $\begin{array}{l}\text { Submitted to } \\
\text { Speaker }\end{array}$ & Yes & Yes & Yes & Yes & Yes & Yes & \\
\hline $\begin{array}{c}\text { Submitted to } \\
\text { Chair of dedicated } \\
\text { committee }\end{array}$ & Yes & Yes & Yes & Yes & Yes & Yes & \\
\hline $\begin{array}{l}\text { Copied to other } \\
\text { relevant } \\
\text { committees }\end{array}$ & Yes & Yes & Yes & Yes & Yes & Yes & \\
\hline $\begin{array}{l}\text { Briefings } \\
\text { organised for } \\
\text { Parliamentary } \\
\text { committee }\end{array}$ & Yes & Yes & Yes & Yes & Yes & Yes & $\begin{array}{l}\text { Audit results were } \\
\text { presented during } \\
\text { the meetings of the } \\
\text { competent } \\
\text { Parliamentary } \\
\text { commissions }\end{array}$ \\
\hline $\begin{array}{c}\text { Summaries } \\
\text { submitted to } \\
\text { Parliament }\end{array}$ & No & No & No & No & No & No & \\
\hline
\end{tabular}

3) Parliamentary procedures for SAI reports

The procedures for SAI reposts are regulated by the Parliament's Rules of Procedure: 
- There is a State Audit Committee chaired by a member of the opposition or the government party, (this results from the parity of Parliament distribution).

- The Committee does not appoint a rapporteur.

- There are hearings of the Committee during which reports are considered. After a discussion, the Committee prepares opinions or recommendations to the Government to eliminate remove irregularities.

- Other committees also analyse and discuss the submitted reports.

Parliament has a fixed procedure for discharge. It is regulated by the chapters of the Constitution in which the Parliament grants its discharge on the State budget execution for the previous year together with NIK analysis of the State budget execution.

\section{Staffing}

The State Audit Committee consists of 17 MPs, including one Chair and three Deputy Chairs.

\section{SAI involvement in consideration of reports by Parliament}

The President and management of NIK are involved in the Committee's work. They attend the meetings during which NIK reports are debated.

\section{4) SAl reports}

NIK focuses on generic and systemic recommendations in its audit reports that are also submitted to the Parliament. The reports also often focus on internal control systems. All reports include NIK opinions and comprehensive recommendations that are to be implemented in order to remove the irregularities revealed during an audit.

\section{5) Follow-up on SAI reports}

NIK monitors the execution of recommendations, for instance via follow up audits that check whether the necessary changes were implemented or not.

\section{6) Audits on Parliament's request}

Parliament's Rules of Procedure and the Supreme Audit Office Act enable the Parliament to request audits.

\section{7) Work programme}

During the meeting of the State Audit Committee, NIK presents its annual work plan. As a result of discussions, explanations and submitted suggestions, the work plan is adopted and accepted by the Committee. The Parliament's requests for audits are accepted, if similar subject matter has not been previously audited.

\section{8) Level and frequency of contacts}

Regular contacts with the Parliamentary committees are held, both of formal and informal. Two employees from the Corporate Services Department at NIK are tasked with on-going relations with the Parliament. 


\section{9) Good practice}

NIK prepares tailored-made legal acts, and suggest how to change the law in order to implement its conclusions and recommendation. NIK's legal department drafts amendments and monitors how they proceed through Parliament.

\section{0) Perspective}

There is no binding regulations that would oblige the Parliament to implement NIK's proposals for new legislation. 


\section{PORTUGAL}

Court of Auditors

\section{1) Legal framework}

The Portuguese Constitution states that the Court of Auditors (Tribunal de Contas) is a sovereign body. Therefore the Court is independent of the Parliament and any other Institution.

Nevertheless, there are forms of co-operation between the two institutions.

Under the Constitution, the President of the Parliament receives the General State Account together with the report and opinion of the Court of Auditors on it from the President of the Court.

The Law on Organisation and Procedure of the Court sets out that the Parliament may ask the Court to undertake audits on specific entities or matters, and for existing audit reports to be sent to it.

The Parliament may ask the Court for information obtained while carrying out the monitoring of the State Budget implementation, reports on the results of that control, and clarifications necessary to the appreciation of the State Budget and the General State Account.

The Court's annual activity report is sent to the President of the Republic, the Parliament, the Government and the governing bodies of the autonomous regions of Madeira and Azores.

It is a competence of the Court to approve legal opinions requested by the Parliament, or the Government, on bills related to financial matters.

The Court provides its opinion on the annual account of the Parliament. The Court sends its annual account to the Parliament for information.

Note: We must emphasise that the Court publishes all its reports by several means.

\section{2) SAI reporting practices}

The Court may send all kinds of reports to the Parliament.

The Parliament may ask the Court for any kind of audit reports. As said before, the Court's annual activity report is sent to the Parliament, as well as to the President of the Republic, the Government and the governing bodies of the autonomous regions of Madeira and Azores.

Reports are addressed to the President of the Parliament and/or to the Chairs of dedicated committees. The reports sent are in respect to the results of individual audits.

There are no timescales or deadlines for sending reports to the Parliament.

\section{Procedures for sending reports to Parliament}

There are specific procedures in place, which are flexible. 
Number and type of reports

\begin{tabular}{|c|c|c|c|c|c|c|c|}
\hline & $\begin{array}{l}\text { Financial } \\
\text { audit } \\
\text { reports }\end{array}$ & $\begin{array}{l}\text { Compliance } \\
\text { audit reports }\end{array}$ & $\begin{array}{l}\text { Performance } \\
\text { audit reports }\end{array}$ & $\begin{array}{l}\text { Other reports or } \\
\text { documents }\end{array}$ & $\begin{array}{l}\text { Annual } \\
\text { activity } \\
\text { reports }\end{array}$ & $\begin{array}{l}\text { Reports at } \\
\text { request of } \\
\text { Parliament }\end{array}$ & Remarks \\
\hline $\begin{array}{l}\text { Number } \\
\text { submitted }\end{array}$ & & & & & & & 24 (total) \\
\hline $\begin{array}{c}\text { Number } \\
\text { discussed by } \\
\text { Parliament }\end{array}$ & & & & & & & $\begin{array}{l}\text { The Court presents (not } \\
\text { discuss) its reports to } \\
\text { the dedicated } \\
\text { committees. The Court's } \\
\text { reports are taken into } \\
\text { consideration by the } \\
\text { Parliament }\end{array}$ \\
\hline $\begin{array}{l}\text { Submitted to } \\
\text { Speaker }\end{array}$ & & & & & & & Yes \\
\hline $\begin{array}{l}\text { Submitted to } \\
\text { Chair of } \\
\text { dedicated } \\
\text { committee }\end{array}$ & & & & & & & Yes \\
\hline $\begin{array}{l}\text { Copied to other } \\
\text { relevant } \\
\text { committees }\end{array}$ & & & & & & & Yes \\
\hline $\begin{array}{c}\text { Briefings } \\
\text { organised for } \\
\text { Parliamentary } \\
\text { committee }\end{array}$ & & & & & & & - \\
\hline $\begin{array}{l}\text { Summaries } \\
\text { submitted to } \\
\text { Parliament }\end{array}$ & & & & & & & $\begin{array}{c}\text { Reports include } \\
\text { executive summaries }\end{array}$ \\
\hline
\end{tabular}

\section{3) Parliamentary procedures for SAI reports}

The Courts' reports aim to inform and support the Parliament in the appreciation and debate of matters related to the audited entities or issues.

There are no fixed procedures for handling SAI reports laid down in Parliament's rules of procedure.

There is no dedicated committee for handling SAI reports. Most reports are sent to the Budget and Finance Committee.

There are no hearings involving the auditee or other appropriate persons invited to provide clarification or further information. 
It is possible that other committees, apart from a particular dedicated committee, also consider the Court's reports.

According to the Constitution, the Parliament discharges the General State Account considering the audit report and opinion of the Court of Auditors.

Usually the acts of the Portuguese Court of Auditors (Tribunal de Contas), including audit reports, are not subject to discussion in the Parliament or any of its committees. However, in what concerns the Court's report and opinion on the General State Account, a rapporteur is appointed to draft a report on the Court's documents which is taken into consideration in the discussion of the Account in the Budget and Finance Committee, before the approval of the Account by the Parliament.

\section{Staffing}

Parliament Committees are supported by experts, and for the Budget and Finance Committee, there is a specific unit for technical support.

\section{SAl involvement in consideration of reports by Parliament}

When matters connected to audit reports' contents are in debate the Parliament normally asks the Court to attend the meetings.

\section{4) SAI reports}

As a rule, internal control systems are carefully examined and evaluated in the course of the Court's audits. Audit reports contain clear conclusions and audit opinions.

\section{5) Follow-up on SAI reports}

The Court undertakes a systematic follow-up of the acceptance of its recommendations and the way they are implemented, and its report and opinion on the General State Account referred to above includes a chapter dedicated to its results. In every audit of an entity to which recommendations have been made on previous reports, compliance with the recommendations is always verified.

The Court's reports are not used as input for the annual debates on draft budgets.

Another specific kind of follow-up which characterises a Court like ours is that when illegalities or facts originating liability are found, the Court's Jurisdictional Chamber has the power to judge the managers.

\section{6) Audits on Parliament's request}

There are provisions in the law permitting Parliament to ask the Court for audit reports as well as to carry out audits to particular entities or on specific issues. The frequency of Parliament's requests depends on the need for this support, and therefore is variable. The Court is obliged by law to carry out two audits per year. If other requests are made, the Court analyses them in the context of its annual audit programme. Usually the Court tries to accommodate the requests.

\section{7) Work programme}

The Court does not consult Parliament on its annual Work programme of audits. 


\section{8) Level and frequency of contacts}

Contacts between the Court and Parliament take place whenever there are relevant matters to be addressed, following no particular schedule. The executive relations are undertaken with the competent departments of the Court under the co-ordination of the President and the Director General.

\section{9) Good practice}

We consider that our relations with the Parliament are relatively formal, with a special concern to safeguard the Court's independence, and at the same time are most cooperative and fruitful. 


\section{ROMANIA}

\section{Court of Accounts}

\section{1) Legal framework}

The Romanian Court of Accounts is an autonomous, specialised central authority, regulated by IV Heading in the Romanian Constitution, revised and republished in 2003. Article No. 140 of the Constitution states:

1. The Court of Accounts shall exercise control over the formation, administration, and use of the financial resources of the State and public sector. Under the terms of the organic law, the disputes resulting from the activity of the Court of Accounts shall be resolved by specialised courts of law.

2. The Court of Accounts shall annually report to Parliament on the accounts of the national public budget administration in the last complete budget year, including cases of mismanagement.

3. At the request of the Chamber of Deputies or the Senate, the Court of Accounts shall check the management of public resources, and report on its findings.

4. Counsellors of accounts shall be appointed by the Parliament for a term of office of 9 years, which cannot be extended or renewed. Members of the Court of Accounts shall be independent in exercising their term of office and irremovable throughout its duration. They shall be subject to the incompatibilities the law stipulates for judges.

5. The Court of Accounts shall be renewed with one third of the counsellors of accounts appointed by the Parliament, every 3 years, under the terms stipulated by the organic law of the Court.

6. The Parliament shall be entitled to revoke the members of the Court of Accounts, in the instances and under the terms stipulated by the law.

The Legal framework for specific activities development is established by Law No. 94/1992 on the organisation and functioning of the Court of Accounts, republished, with subsequent amendments and completions.

According to the law, the main obligations of the Court of Accounts to Parliament are:

- The Court of Accounts shall submit to the Parliament, on an annual basis, a report on the national public budget management accounts of the closed budget exercise, also identifying the irregularities found (Article No. 4 paragraph 1).

- The Court of Accounts may submit to the Parliament or, by the intermediary of the county chambers of accounts, to the deliberative public authorities of the administrative and territorial units, reports in the domains under its jurisdiction, whenever the Court shall deem it necessary (Article No.40).

- Whenever the Court of Accounts deems it necessary, it shall submit to the Parliament and, through the county and Bucharest Municipality chambers of accounts, to local, county and Bucharest Municipality councils, reports in the fields under its jurisdiction (Article No. 4 paragraph 3). 
- The Court of Accounts shall endorse, upon request by the Senate or by the Chamber of the Deputies, the State budget draft and the law drafts in the field of public finances and accounting or the ones by the enforcement of which a diminishment of the revenues or a maximisation of the expenditure approved by the budget law would result (Article No. 41).

- Upon request by the Chamber of Deputies or by the Senate, the Court of Accounts shall examine the public resources management and shall report on the findings (Article No. 4 paragraph 2).

- The controls by the Court of Accounts shall be launched ex officio and may only be stopped by the Parliament and solely when the powers set by law have been exceeded (Article No. 3 paragraph 2).

- The decisions by the Chamber of Deputies or by the Senate requesting the Court of Accounts to conduct audits within its powers, shall be mandatory. No other public authority may request the Court to do so (Article No. 3 paragraph 3).

- The implementation of the budgets of the Chamber of Deputies, the Senate, the Presidential Administration, the Government, the High Court of Cassation and Justice, the Constitutional Court, the Legislative Council and Ombudsman shall be exclusively controlled by the Court of Accounts (Article No. 25).

- The Court of Accounts' budget shall be controlled by a commission set up in this respect by the two Chambers of the Parliament (Article No. 25 paragraph 2).

Law No. 500/2002 on public finances, with subsequent amendments and completions, states at Article No. 56 paragraph 5: "Annual general account of the state budgets execution, state social insurance budget and the other annual execution accounts are approved by law after their checking by the Court of Accounts."

\section{2) SAI reporting practices}

According to Article No. 140 of the Romanian Constitution, the Court of Accounts shall annually report to Parliament on the accounts of the national public budget administration in the last complete budget year, including cases of mismanagement.

The Law No. 94/1992 states:

- The Court of Accounts shall submit to Parliament, on an annual basis, a report on the national public budget management accounts of the closed budget exercise, also identifying the irregularities found (Article No. 4 paragraph 1).

- The Court of Accounts may submit to Parliament or, by the intermediary of the county chambers of accounts, to the deliberative public authorities of the administrative and territorial units, reports in the domains under its jurisdiction, whenever the Court shall deem it necessary (Article No. 40).

- Whenever the Court of Accounts deems it necessary, it shall submit to Parliament and, through the county and Bucharest Municipality chambers of accounts, to local, county and Bucharest Municipality councils, reports in the fields under its jurisdiction (Article No. 4 paragraph 3). 
- Upon request by the Chamber of Deputies or by the Senate, the Court of Accounts shall examine the public resources management and shall report on the findings (Article No.4 paragraph 2).

- The decisions by the Chamber of Deputies or by the Senate requesting the Court of Accounts to conduct audits within its powers, shall be mandatory. No other public authority may request the Court to do so (Article No. 3 paragraph 3 ).

- Within 6 months as of receipt of the accounts provided under art. 26 from the bodies competent to establish them and kept to forward them, the Court of Accounts shall draft the annual public report and shall submit it to the Parliament (Article No. 38 paragraph 1).

- The annual public report shall comprise: the observations of the Court of Accounts on the implementation accounts of the budgets subjected to its control; the conclusions devolving from the audits ordered by the Chamber of Deputies or the Senate or conducted on autonomous administration authorities, commercial companies with integral or majority state owned capital and other legal entities under the Court control competence; the law infringements found and the measures taken to bring to account the liable parties; other issues which the Court shall deem necessary (Article No. 39).

As mentioned above, the most important report submitted by the Court of Accounts to the Parliament is the annual public report on the national public budget management accounts of the closed budget exercise. This report includes mainly results from a large number of financial audits on public accounts, but also control (compliance) and performance audits. It is sent to Parliament within 6 months of receipt of the accounts provided under Article No. 26 of the Law, from the bodies responsible for them and kept to forward them;

The Court of Accounts may submit to the Parliament, for information, reports in the domains under its jurisdiction, whenever the Court deems it necessary. The Court submitted to the Parliament:

- summaries of performance audits and special audit reports on various subjects;

- summaries of individual financial audits of relevant principal spending authorities;

- summaries of financial audit reports on the implementation of accounts of the budgets subjected to autonomous administration authorities.

The annual public report is submitted to the Speakers of the two Chambers of the Parliament, to the chairs of the budget, finance and banks standing committees of the Senate and Chamber of Deputies, to the members of these committees, and to all the members of the Parliament. The annual public report is sent to the Parliament with the annual activity report of the Court of Accounts.

This report is sent to the Parliament within 6 months of receipt of the accounts provided under Article No. 26 of the law, from the bodies responsible for them.

\section{Procedures for sending reports to Parliament}

The Court of Accounts have a specific procedure for sending its reports to Parliament, starting with Article No. 58 of the Law No. 94/1992 that states:

"The following shall be the powers and duties of the plenum of the Court of Accounts:

m) approval of the reports to be submitted to Parliament;" 
The Court of Accounts adopted internal regulations giving the procedures on drafting the annual public report and other reports that are submitted to Parliament and to the deliberative public authorities of the administrative and territorial units.

Number and type of reports

\begin{tabular}{|c|c|c|c|c|c|c|c|}
\hline & $\begin{array}{l}\text { Financial } \\
\text { audit } \\
\text { reports }\end{array}$ & $\begin{array}{l}\text { Compliance } \\
\text { audit reports }\end{array}$ & $\begin{array}{c}\text { Performance audit } \\
\text { reports }\end{array}$ & $\begin{array}{l}\text { Other reports } \\
\text { or documents }\end{array}$ & $\begin{array}{l}\text { Annual } \\
\text { activity } \\
\text { reports }\end{array}$ & $\begin{array}{l}\text { Reports at } \\
\text { request of } \\
\text { Parliament }\end{array}$ & Remarks \\
\hline Number submitted & 5 & - & 6 & \begin{tabular}{|c|}
1 Public Report \\
for year $2014+$ \\
1 Special Report
\end{tabular} & 1 & - & \\
\hline $\begin{array}{l}\text { Number discussed } \\
\text { by Parliament }\end{array}$ & - & - & - & - & - & - & \\
\hline $\begin{array}{l}\text { Submitted to } \\
\text { Speaker }\end{array}$ & 5 & - & 6 & \begin{tabular}{|c|}
1 Public Report \\
for year $2014+$ \\
1 Special Report
\end{tabular} & 1 & - & \\
\hline $\begin{array}{l}\text { Submitted to Chair } \\
\text { of dedicated } \\
\text { committee }\end{array}$ & 5 & - & 6 & \begin{tabular}{|c|}
1 Public Report \\
for year $2014+$ \\
1 Special Report
\end{tabular} & 1 & - & \\
\hline $\begin{array}{l}\text { Copied to other } \\
\text { relevant } \\
\text { committees }\end{array}$ & 5 & - & 6 & \begin{tabular}{|l|}
1 Public Report \\
for year $2014+$ \\
1 Special Report
\end{tabular} & 1 & - & \\
\hline $\begin{array}{l}\text { Briefings organised } \\
\text { for Parliamentary } \\
\text { committee }\end{array}$ & - & - & - & - & - & - & \\
\hline $\begin{array}{l}\text { Summaries } \\
\text { submitted to } \\
\text { Parliament }\end{array}$ & 5 & - & 6 & \begin{tabular}{|c|}
1 Public Report \\
for year $2014+$ \\
1 Special Report
\end{tabular} & - & - & \\
\hline
\end{tabular}

\section{3) Parliamentary procedures for SAI reports}

The Parliament Regulation on the joint activities of the Chamber of Deputies and of the Senate, at Article No. 13, contain some provisions about the Court of Accounts:

"The Chamber of Deputies and the Senate meet in joint sittings for:

2. approving the State budget and the budget of the social state insurance, for rectifying laws, and for approving the budget execution account;

7. examining the reports of the Supreme Council of National Defence and of the Court of Accounts;

20. appointing the members of the Court of Accounts." 
The Parliamentary committees are working bodies of the Chambers of Parliament, playing an important part in the preparation of the proceedings, as well as carrying out parliamentary functions, particularly legislative and control issues.

In the Romanian Parliamentary system, according to the Constitution, the Chambers may create standing committees, temporary inquiry committees, or other special committees. Likewise, joint committees may be set up for the Chamber of Deputies and the Senate. All these committees are formed under the political configuration of each Chamber.

The Chamber of Deputies has the standing Committee for Budget, Finance and Banks with the following fields of activity: the State budget and budget execution; the State social insurance budget and its execution; financial policy taxes and duties system, insurance and reinsurance; monetary balance, monetary circulation, credits and credit system, interest, discount; stock exchange and commercial papers; external loans of the State or guaranteed by the State; investments out of budgetary credits. This committee has 33 members (deputies).

In the Senate is a similar standing Committee for Budget, Finance and Banks, with 11 senators.

These two standing committees deal with the annual public report in joint sittings, and debate the draft laws on the annual state budget execution and state social insurance budget (presented by the Government for approval in the Parliament). The committees may analyse separately other reports received from the Court of Accounts.

The Law No. 94/1992, provides the following powers to these two standing committees:

- Article No. 46, paragraph 1: The members of the Court of Accounts shall be appointed by the Parliament, upon proposal of the permanent Commissions for Budget, Finances and Banks of the two Chambers, for a nine year term of office, which may not be extended or renewed;

- Article No. 50, paragraph 3: Revocation of the Court of Accounts' members shall be enforced by Parliament, upon proposal of the specialised commissions provided under Article No. 46 paragraph 1.

The composition of the bureau of the two Budget, Finance and Banks Committees in Parliament is settled, in each case, separately, depending on the political configuration of the respective Chamber, and on the negotiations between the representatives of the Parliamentary groups.

The two standing Committees of Budget, Finance and Banks provide for the Plenum of the Parliament a joint report on the draft laws of the annual state budget execution and state social insurance budget execution, using the annual public report of the Court of Accounts, under Law No. 500/2002 on public finances, Article No. 56 paragraph 5, "Annual general account of the state budgets execution, state social insurance budget and the other annual execution accounts are approved by law after their checking by the Court of Accounts." The join report is the result of the work of the two committees, not of individual rapporteurs (Members of Parliament).

The Court of Accounts submits to Parliament the annual public report on the national public budget management accounts of the closed budget exercise.

The Court of Accounts may submit to Parliament, for information, reports in the domains under its jurisdiction, whenever the Court deems it necessary. 
Whenever the standing committees of the two Chambers of the Parliament considers it useful, it may invite representatives of the Court to provide clarification or further information on these summaries.

The annual public report is presented in the Plenary of the Parliament during the debate of the draft laws approving the State budget and the budget of the social state insurance execution accounts, under Article No. 13 in the Parliament Regulation on the joint activities of the Chamber of Deputies and of the Senate:

"The Chamber of Deputies and the Senate meet in joint sittings for:

2. approving the State budget and the budget of the social state insurance, for rectifying laws, and for approving the budgetary execution account;

7. examining the reports of the Supreme Council of National Defence and of the Court of Accounts."

The Court of Accounts reports submitted to the Chamber of Deputies or to the Senate, according to Article No. 140, paragraph 3 of the Constitution ${ }^{42}$ and of Article No. 4, paragraph 2 of Law 94/1992 $2^{43}$, are debated in the Plenary of the Chamber of the Parliament that requested the audit.

Summary reports are sent to the standing committees for information, mostly to the Budget, Finance and Banks Committees of the two Chambers of Parliament, according to Article No. 4, paragraph 3 of Law No. $94 / 1992^{44}$, such as: summaries of performance audits and special audit reports on various subjects, summaries of individual financial audits of relevant principal spending authorities, summaries of financial audit reports on the implementation of accounts of the budgets subject to autonomous administration authorities, and other reports are analysed, separately, in these two committees.

As well ascending reports to the Budget, Finance and Banks Standing Committees, the Court of Accounts sends summary reports to other standing committees, for information, depending on the subjects and domains specific to those committees' jurisdiction. All these summary reports are analysed only in the standing committees and not in the Plenary of the Chamber of Deputies or the Senate.

Draft bills or legislative proposals are submitted for debate to the Chamber of Deputies or to the Senate. This is also the procedure for the two drafts for approval of the budget execution account of the State budget and of the social state insurance budget that are debated in the joint sittings of the Chamber of Deputies and the Senate.

After the two bills have been received from the Government and registered, the joint standing bureau of Chamber of Deputies and of the Senate will distribute them to the Parliamentarians and send them to Budget, Finance and Banks Standing Committees for examination in joint sittings, for an advisory opinion.

To draft the joint reports for the Plenary of the Parliament, the Budget, Finance and Banks Standing Committees have to analyse the annual public report of the Court of Accounts.

42 "At the request of the Chamber of Deputies or the Senate, the Court of Accounts shall check the management of public resources, and report on its findings."

43 "Upon request by the Chamber of Deputies or by the Senate, the Court of Accounts shall examine the public resources management and shall report on the findings."

4

"Whenever the Court of Accounts deems it necessary, it shall submit to the Parliament and, through the county and Bucharest Municipality chambers of accounts, to local, county and Bucharest Municipality councils, reports in the fields under its jurisdiction." 
In the joint reports are mentioned the Court of Accounts conclusions and findings from the annual report, such as: the observations on the implementation accounts of the budgets subject to its control; the conclusions arising from the audits ordered by the Chamber of Deputies or the Senate or conducted for autonomous administration authorities, commercial companies with integral or majority state owned capital and other legal entities under the Court control competence; the law infringements found and the measures taken to bring to account the liable parties; other issues which the Court deems necessary.

After finalising the joint reports, the two draft laws for approval of the annual budgetary execution account of the State budget and of the social state insurance budget are debated in the Plenary.

The joint reports of the two Budget, Finance and Banks Standing Committees are published on the Parliament website.

The draft bills for which joint reports have been drawn up by the relevant committees are entered on the agenda of the Parliament.

If the draft bills have been adopted, they are signed by the presidents of the two Chambers of the Parliament are sent for promulgation to the President of Romania.

The laws come into force three days after the publication in the Official Gazette of Romania.

\section{Staffing}

The staff of each standing committee of the two Chambers of the Parliament consists of Parliamentary public servants, which are part of the General Secretariat, according to the internal organisation chart. The functioning of standing committee and the number of Parliamentary public servants working for each of them is settled by internal regulations of the committees, which are not made public.

The standing committees may invite interested persons, as well as specialists on behalf of certain public authorities or other specialised institutions, to participate in their sittings.

\section{SAI involvement in consideration of reports by Parliament}

The SAI have no involvement in the committee or parliaments preparation for hearings.

The annual public report is presented in the Plenary of the Parliament during the debate on the draft laws approving the State budget and the budget of the social state insurance execution accounts, under Article No. 13 of the Parliament Regulation on the joint activities of the Chamber of Deputies and of the Senate. On this occasion, the Court of Accounts is represented at the highest level, by the President of the Court or a vice president, who presents a summary of the annual public report in the Plenary of the Parliament.

When summary reports are sent to the standing committees for information, mostly to the Budget, Finance and Banks Standing Committees of the two Chambers of the Parliament, the chairs of the committees may invite the president or vice presidents of the Court or counsellors of accounts (members of the Plenum of Court) to attend and present the results of the work carried out by the Court. Others may attend the meetings, including the top management of the Court, directors and other executives specialised in the subject presented in the summary reports. 


\section{4) SAI reports}

Under Article No. 39 of the Law No. 94/1992, the annual public report the Court of Accounts must refer to the following issues: the observations of the Court of Accounts on the implementation of the budgets subject to its control; the conclusions arising from the audits ordered by the Chamber of Deputies or the Senate or conducted for autonomous administration authorities, commercial companies with integral or majority state owned capital and other legal entities under the Court control competence; the law infringements found and the measures taken to bring to account the liable parties; other issues which the Court shall deem necessary.

Also, in the annual public report, there is a chapter highlighting the evaluation of the internal control/management system in the public sector. This chapter includes the main findings about how the legal requirements have been implemented regarding internal/management control by public entities managers who have this responsibility.

According to Article No. 32, paragraph 2 of the Law No. 94/1992, the external public auditors appointed to audit the accounts, as well as the other activities for which the Court of Accounts is competent, shall draft reports listing the findings and the conclusions, make recommendations about the steps to be taken and express an opinion on them, in compliance with the procedures set in the regulation, approved in keeping with Article 11 paragraph $2^{45}$.

\section{5) Follow-up on SAI reports}

The Court of Accounts develops its activity autonomously and performs three types of audit: financial audit, performance audit and compliance audit (thematic control) covered in detail in the annual public report.

Article No. 33 of Law 94/1992 states that "The audit reports follow-up shall be done in keeping with the regulation approved according to art. 11 paragraph $2^{46}$. If regularity of the accounts is found, a conformity certificate shall be issued and notified to the auditee. If deviations from legality and regularity are found, which caused losses, the audited public entity management shall be notified. Setting the extent of the damage and ordering the steps to recover it is the auditee management's responsibility. If audit reports highlight indications of criminal law infringement, the department manager shall notify the relevant bodies to ensure follow-up of the findings, and shall notify the audited entity. When it proves impossible to draft an audit report, the auditee shall be ordered to complete and/or re-draft the accounts examined."

According to Article No. 35 "The auditee may make written objections to the findings contained in the reports drafted by external public auditors, within 15 days of receipt of the report. The objections shall be submitted to the head auditing institution, and shall be considered on follow-up of findings."

The main instrument that measures the impact of the Court of Account's work on the quality of management of public funds and public propriety is the follow-up report. This report is drafted in order to verify the way the audited entities:

\footnotetext{
$45 \quad$ Article No.11, paragraph (2): "The organisation and development of the activities specific to the Court of Accounts, as well as the follow up of the documents resulting from these activities, shall be performed in keeping with the regulation approved by the plenum of the Court of Accounts, in accordance with this law." 
- implemented the measures ordered by Court of Accounts decisions;

- implemented the recommendations issued in the performance audit.

The Parliament does not pay attention to the implementation of SAI recommendations in audit reports and the mechanisms used by them to do so.

In the annual public report, there is a chapter highlighting the "Evaluation of the internal control/management system" in the public sector. This chapter includes the main findings on the way in which the legal requirements have been implemented in internal/management control by public entities managers who have this responsibility.

SAI reports are not regularly used as input for the annual debate on draft budgets.

\section{6) Audits on Parliament's request}

Two legal provisions enable Parliament to request audits.

In the Romanian Constitution, Article No. 140, paragraph 3: "At the request of the Chamber of Deputies or the Senate, the Court of Accounts shall check the management of public resources, and report on its findings."

In Law No.94/1992, Article No. 4 paragraph 2 and Article No. 3 are relevant. Article No. 4 paragraph 2 states that "upon request by the Chamber of Deputies or by the Senate, the Court of Accounts shall examine the public resources management and shall report on the findings." Article No. 3, paragraph 3 states that "the decisions by the Chamber of Deputies or by the Senate, requesting the Court of Accounts to conduct audits, within its powers, shall be mandatory. No other public authority may request the Court to do so."

The latest request was made in 2009 by the Chamber of Deputies: to check the amounts spent by the Ministry of Tourism in order to promote the image and tourism in Romania.

The latest request made by the Senate was in 2012, asking to include in the activity programme of 2012 financial audits for six administrative and territorial units.

\section{7) Work programme}

According to Article No. 3 of the Law No. 94/1992: "The Court of Accounts shall autonomously decide on its activity program. Audits by the Court of Accounts shall be carried out ex officio and may only be stopped by the Parliament, and solely when the powers set by law have been exceeded. The decisions by the Chamber of Deputies or by the Senate, requesting the Court of Accounts to conduct audits, within its powers, shall be mandatory. No other public authority may request the Court to do so."

\section{8) Level and frequency of contacts}

There are regular contacts between the President of the Court, the Speaker of the Parliament, and the Chairs of the Budget and Finance Committees. When necessary, there is also contact with the Chairs of relevant Parliamentary committees. There is no strict rule about when these meetings are to be held. When presenting the annual public report to Parliament, it is clear that informal contacts are developed, but there are also other occasions for such informal relationships. The current President of the Court has a very solid Parliamentarian background (being the Speaker of the Senate, the highest chamber of our 
Parliament, for eight years) and therefore his relationship with members of the Parliament is a privileged one.

At working level we have contacts with relevant staff in Parliament, but no special unit in the Court has this purpose. Mainly these contacts are developed by the Director of the President's Office or /and by the Head of International Relations Unit.

\section{9) Good practice}

In general, Good practice requires the existence of a specific PAC to deal exclusively with the SAI reports/findings. In Romania we have not yet set up such a committee. We address the relevant committees of the Senate and Chamber of Deputies as required.

\section{0) Perspective}

The Court considers that the establishment of a PAC in the near future will enhance our relations with Parliament. The Court had already discussed this with Parliament several times recently, and we are expecting positive results.

11) Are there any other relevant features of the current relations between the SAI and Parliament that you would like to highlight, and how have they evolved over the past five years?

We believe that the relations between the Court and Parliament are continuously improving, and the role of the SAI in Romania is highly appreciated by the MPs. 


\section{SERBIA}

State Audit Institution

\section{1) Legal framework}

Article 96 of the Constitution of the Republic of Serbia reads:

"The State Audit Institution (SAI) shall be the supreme state body for auditing public finances in the Republic of Serbia, independent and subject to supervision by the National Assembly to which it accounts for its work. The Law on the State Audit Institution shall be enacted."

This confirms autonomy and independence of the SAI, subject to supervision of the National Assembly, to which it is obliged to report.

In the Law on the State Audit Institution, SAI is defined as supreme state authority for audit of public funds in the Republic of Serbia, as independent and autonomous state body, which reports to and is subject to supervision by the legislative body, the National Assembly, for activities stemming from its competence.

Part 5 of the Law on the SAI, relates to Reporting, as follows:

Reporting to the Assembly (Article 43):

The Institution shall inform the Assembly by submitting:

1. the annual activity report;

2. special reports during the year;

3. audit report on the annual balance sheet of the Republican budget, annual balance sheets of the financial plans of mandatory insurance organisations and consolidated financial statements of the Republic.

The content of reports under paragraph 1 of this Article shall be more closely defined by the Rules of Procedure.

Reporting to the assemblies and local authorities (Article 44):

The Institution shall report to the local assemblies on audits pertaining to the auditee which are within their competence.

The reports under paragraph 1 of this Article shall be submitted to the Assembly at the same time.

Annual activity reports of the Institution (Article 45):

By 31 March, the Institution shall submit to the Assembly the annual activity report of the Institution for the previous year.

Special reports (Article 46): 
The Institution may, during the year, submit to the Assembly the special reports on particularly important or urgent matters, which, according to the Council, should not be postponed until the next regular report.

The Institution shall, at the Assembly request, submit the reports containing the requested information and data, in accordance with the law.

Reports on the audit of the final accounts of the Republican budget, annual balance sheets of financial plans of mandatory social insurance organisations and consolidated financial statements of the Republic of Serbia are covered by Article 47.

In the procedure for passing the final accounts of the Republic, the Institution shall report to the Assembly on the results of the audit of the final accounts of Republican budget, annual balance sheets of financial plans of mandatory social insurance organisation and consolidated financial statements of the Republic in accordance with the law regulating the budget system.

Reviewing the report (Article 48):

The competent Assembly body shall, following the review of the Institution report, submit its opinions and recommendations to the Assembly in form of report.

On basis of significant facts and circumstances which were indicated in the reports under paragraph 1 of this Article, the Assembly shall decide upon the proposed recommendations, measures and timeframes for their implementation.

The Assembly may request from the Institution additional clarifications of certain facts and circumstances.

Publicity of work (Article 49):

The Institution's work is public and compliant with the law and Rules of Procedure.

The Institution shall submit its activity report to the Assembly for consideration at least once a year.

The Budget System Law (BSL) defines external audit in Article 92:

The annual financial statements of the Republic of Serbia and annual financial statements of the organisations for mandatory social insurance shall be subject to external audit, pursuant to the provisions of the law regulating the jurisdiction the Supreme Audit Institution.

Annual financial statements of local government budgets shall also be subject to external audit.

The audit referred to in paragraph 2 of this Article shall be performed by the Supreme Audit Institution in line with the law regulating the jurisdiction of the Supreme Audit Institution.

Notwithstanding paragraph 3 of this Article, external audit of local government budgets may also be performed, with the consent of the Supreme Audit Institution, based on the decision of the local government assembly, by a person fulfilling the conditions for the performance of financial statement audit activities prescribed by the law regulating accounting and audit. 
The Law on the financing of political parties defines control by the SAl in its Article 34 as follows:

The (Anti-Corruption) Agency may, after conducting a review of financial reports of a political entity, forward a request to the State Audit Institution to audit these reports, in accordance with the law governing competencies of the State Audit Institution.

\section{2) SAI reporting practices}

SAI Serbia sends to the Parliament (National Assembly) financial audits, compliance audits, performance audits, and annual (activity) reports.

On one occasion, based on the conclusion of the National Assembly, after consideration of the 2012 Activity Report of the SAI, the SAI submitted to the National Assembly a separate report on the implementation of recommendations in the audit reports for 2011. This report included an overview of implementation which was monitored by the SAI during 2013, until 25th September 2013.

The SAI reports separately on individual audits.

Reports are addressed to National Assembly in general.

By 31 March each year, the SAI submits to the Assembly the annual activity report of the SAI for the previous year.

\section{Procedures for sending reports to Parliament}

Upon submitting all audit reports to the National Assembly for the particular year, the SAl informs the Chair of the dedicated committee (Committee on Finance, State Budget and Control of Public Spending) by a formal letter that the SAI audit programme for the year has been completed, and asking the Chair to schedule the session of the Committee so that the SAI can present the key findings from the audit reports to the MPs. 
Number and type of reports

\begin{tabular}{|c|c|c|c|c|c|c|c|}
\hline & $\begin{array}{l}\text { Financial } \\
\text { audit } \\
\text { reports }\end{array}$ & $\begin{array}{l}\text { Compliance } \\
\text { audit reports }\end{array}$ & $\begin{array}{l}\text { Performance } \\
\text { audit reports }\end{array}$ & $\begin{array}{l}\text { Other reports } \\
\text { or documents }\end{array}$ & $\begin{array}{l}\text { Annual } \\
\text { activity } \\
\text { reports }\end{array}$ & $\begin{array}{l}\text { Reports at } \\
\text { request of } \\
\text { Parliament }\end{array}$ & Remarks \\
\hline Number submitted & 157 & 159 & 1 & 14 & 1 & 0 & \\
\hline $\begin{array}{c}\text { Number discussed } \\
\text { by Parliament }\end{array}$ & & & 1 & & & & $\begin{array}{l}\text { Discussed by the } \\
\text { dedicated } \\
\text { committee (from } \\
\text { the Audit } \\
\text { Programme for } \\
\text { 2014) }\end{array}$ \\
\hline $\begin{array}{c}\text { Submitted to } \\
\text { Speaker }\end{array}$ & & & & & & & $\begin{array}{c}\text { The reports are } \\
\text { submitted to the } \\
\text { National } \\
\text { Assembly }\end{array}$ \\
\hline $\begin{array}{c}\text { Submitted to Chair } \\
\text { of dedicated } \\
\text { committee }\end{array}$ & & & & & & & \\
\hline $\begin{array}{l}\text { Copied to other } \\
\text { relevant } \\
\text { committees }\end{array}$ & & & & & & & $\begin{array}{c}\text { Yes, when } \\
\text { deemed relevant }\end{array}$ \\
\hline $\begin{array}{c}\text { Briefings organised } \\
\text { for Parliamentary } \\
\text { committee }\end{array}$ & & & & & & & $\begin{array}{l}\text { Meetings } \\
\text { between } \\
\text { members of the } \\
\text { subcommittee } \\
\text { and managers of } \\
\text { all audit sectors } \\
\text { are held to } \\
\text { discuss further } \\
\text { steps to monitor } \\
\text { implementation } \\
\text { of } \\
\text { recommendations } \\
\text { issued by the SAl }\end{array}$ \\
\hline $\begin{array}{l}\text { Summaries } \\
\text { submitted to } \\
\text { Parliament }\end{array}$ & & & & & & & $\begin{array}{l}\text { In } 2014, \text { SAI } \\
\text { introduced a new } \\
\text { structure of the } \\
\text { audit report. See } \\
\text { section } 4\end{array}$ \\
\hline
\end{tabular}

\section{3) Parliamentary procedures for SAI reports}

The Rules of Procedure of the National Assembly proscribe the following for SAl: 
Article 55:

The Committee on Finance, State Budget and Control of Public Spending shall consider bills and proposals of other general acts and other issues in the following areas:

- the system of financing public functions, taxes, duties and other public revenues;

- state budget and financial plans of compulsory social insurance organisations;

- the budget financial statements, final financial statements of financial plans of compulsory social insurance organisations and audit of the final financial statements;

- loans, guarantees and lottery;

- the public debt and the financial assets of the Republic of Serbia,

- public procurement;

- the credit and monetary, banking, foreign exchange and customs systems;

- insurance of assets and persons;

- ownership relations and expropriation;

- payments and payment operations, securities and the money market;

- prevention of money laundering and combating corruption;

- accounting and auditing;

- other issues in the field of finance.

The Committee shall:

- consider reports of the State Audit Institution and submit a report with opinions and recommendations to the National Assembly;

- control the implementation of the State budget and accompanying financial plans in regard to legality, purposefulness and efficiency of public spending, and submit a report with recommendations of measures to the National Assembly.

The Committee shall perform other tasks in accordance with the Law and these Rules of Procedure.

The Committee shall have 17 members.

Article 177:

The competent committee shall consider the final financial statements proposal and the report of the SAI on the audit of the financial statements of the Republic of Serbia, financial statements of the financial plans of the compulsory social insurance organisations and consolidated financial reports of the Republic of Serbia, and shall submit a report to the National Assembly in compliance with the law regulating the SAI.

Article 203:

Proposals for the election and dismissal of the Governor of the National Bank of Serbia, the Council of Governors of the National Bank of Serbia, the Ombudsman, the Commissioner for Information of Public 
Importance and the President, Vice President and members of the Council of the State Audit Institution and other officials established by the law, shall be submitted with a rationale to the National Assembly by authorised proposers.

If an authorised proposer for the election of the official referred to in paragraph 1 of this Article, elected by the National Assembly, is not stipulated by the law, the proposal shall be submitted by the competent committee of the National Assembly.

Before the election of the officials referred to in paragraph 1 of this Article, nominated by the competent committee of the National Assembly, interviews shall be carried out with the candidates, before the competent committee of the National Assembly.

As well as the Committee on Finance, State Budget and Control of Public Spending, the Subcommittee for the Consideration of Reports on Audits Conducted by the State Audit Institution was established in February 2015. Members of the newly established subcommittee visited the SAl for the first time, and arranged a closer co-operation for more efficient supervision over spending of the public funds. It was agreed that the SAI and the subcommittee jointly set up a system for monitoring actions taken upon recommendations of the SAI and National Assembly, in order to improve the financial and accountability system in the Republic of Serbia. The SAI is ready to assist both the Committee on Finance, State Budget and Control of Public Spending and the newly-established Subcommittee in understanding the significance of the audit findings and in finding appropriate corrective mechanisms, without compromising its independence.

In National Assembly Convocations (as of 14 February 2007 and 11 June 2008), chairs of the Finance Committee were members of opposition parties, while in National Assembly Convocations (as of 31 May 2012 and the current one) chairs of the Finance Committee were members of position parties.

The Committee does not appoint rapporteurs at all.

There were no hearings to which the auditee or its representatives were invited to provide clarification or further information.

In the years 2011-2015, the debates on SAI audit reports were held in committees. The debates on SAI annual activity reports were held in committee every year. The debates on SAI annual activity reports were held in plenary every year, except in 2015. Committee for Finance, State Budget and Control of Public Spending of the National Assembly of the Republic of Serbia, at the session held on 18 May 2015 discussed the 2014 Annual Activity Report of the SAI and proposal of the conclusion (for the debate in plenary) on the 2014 Annual Activity Report of the SAI was drafted in some of the subsequent sessions.

SAI audit reports were considered in the Security Services Control Committee (audit report on the Security Information Agency).

According to the Rules of Procedure of the National Assembly, the SAI dedicated committee considers reports of the SAI and submits a report with opinions and recommendations to the National Assembly.

The Rules of Procedure of the National Assembly (Articles 171-178) set out the procedure for adoption of the budget of the Republic of Serbia and the final financial statements. The Law on the Final Accounts of the Budget of the Republic of Serbia has not been adopted since 2002. 
The SAI dedicated Committee considers the final financial statement proposal and the report of the SAI on the audit of the financial statements of the Republic of Serbia, financial statements of the financial plans of the compulsory social insurance organisations and consolidated financial reports of the Republic of Serbia, and submits a report to the National Assembly in compliance with the law regulating the SAI.

The audit scope of the SAI is stipulated under Article 92 of the BSL, subject to the detailed provisions set out in the SAI Law, and the requirement to attach the audit report to the financial statements is stipulated in Article 79. However, the BSL is silent on the deadline for submitting the financial statements to the SAI, even though it prescribes in Article 78 the deadline (15 July) for submitting these financial statements (with audit report) to the National Assembly. In the absence of such a deadline, the time given to the SAI to audit the financial statements of the Republican Budget, at the time it is submitted to the Government (20 June), is considered by the SAI to be inadequate.

Audit reports generally identify issues of non-compliance with the BSL, and well as issues of misuse of funds or fraud. While the misuse of funds and fraud issues are dealt with through the courts, noncompliance issues are often systemic and require corrective actions to be taken by the Government. While the more immediate issues are addressed as the audit is undertaken and before the audit report is finalised, there is often a range of outstanding issues which require more protracted effort on the part of Government to address. These should be picked up by the National Assembly in its review of the financial statements and audit report, which should then lead to a formal written response from the Government on planned actions about the shortcomings and over what period of time. This formal process should be reflected in the BSL. Clarification of the timeframe for financial statements and audit arrangements are needed.

In order for the SAI to follow the requirement that final accounts are accompanied by the audit report, deadline for the formal submission of financial statements to the SAI should be 30 April, while the deadline for submission of the audit report accompanying financial statements to the National Assembly should be 30 September. An additional Article should be inserted after Article 92 to govern the process and timeline of final account and audit report review by the National Assembly, including obligation on the Government to address outstanding audit recommendations.

\section{Staffing}

There are two members of Parliamentary staff supporting the committee and the subcommittee.

\section{SAl involvement in consideration of reports by Parliament}

The SAI attends Parliamentary meetings when SAI reports are debated. Auditor General and supreme state auditors, together with Secretary and Head of the Office of the President usually attend these meetings. SAI representatives present their findings and respond to the questions asked by the MPs.

\section{4) SAI reports}

In 2014, SAI introduced a new structure for audit reports. For each completed audit, a base document is prepared. It contains the opinion of the Auditor General on the financial statements and compliance audit. Before opinions, separate subsections cover accountability of the management for preparing financial statements and compliance of operations, as well as the basis for opinion, including any irregularities found. 
Annex 1 contains the key irregularities discovered in the audit process, particularly for financial audit and compliance audits. Recommendations for removing detected irregularities and other improvement measures for the activities that the management of an auditee has undertaken are set out.

Annex 2 are the notes to the audit report. This part explains in more detail all detected irregularities.

Annex 3 includes financial statements of an auditee.

For performance audits, each audit report contains a highlights page comprising of the title of the report, why the SAI did the audit, what the SAI found, and what the SAI recommends.

Each audit report of the SAI contains detailed information on the status of the internal control systems, and clear conclusions and audit opinions.

\section{5) Follow-up on SAI reports}

The SAI keeps track of its recommendations in its internal data base. There is an aim to set up a public database of audit recommendations, facilitating the identification of systemic issues and enhancing the information basis for Parliamentary oversight over the executive.

The SAI annual activity report contains summary of opinions provided, irregularities detected, audit effects, and recommendations issued to auditees, as well as measures taken. On one occasion, based on the conclusion of the National Assembly about the 2012 activity report of the SAl, the SAl submitted to the National Assembly a separate report on the implementation of recommendations issued in audit reports for 2011. This report included an overview, which was monitored by the SAI during 2013.

The effectiveness of the SAl's work is undermined by the absence of specific procedures and deadlines for scrutiny of the audit reports by the Committee for Finance, State Budget and Control of Public Spending. To date, no hearings on the findings documented in the SAl reports to hold the representatives of the executive to account have been held. The Subcommittee for the Consideration of Reports on Audits Conducted by the State Audit Institution was set up in February 2015. The SAI updated the Members of the Subcommittee about systemic weaknesses detected in audits, so that the Members of the Subcommittee would review them in the coming period, and undertake appropriate actions.

The Government as a whole is not required to report on the implementation of SAI recommendations. Each auditee is required to submit a response report to the SAI on implementation of its recommendations.

The current practice for submission of the audited final accounts (December) limits the usefulness of information from the audit report in deliberation of the budget proposal by the Parliament. It is necessary to enforce the constitutional and statutory obligation of the National Assembly for the review and adoption of the final accounts of the budget of the Republic of Serbia as a critical link in the accountability chain. Without ex-post control of the budget, the National Assembly cannot hold the executive accountable for the use of assigned resources and promote improvements in how they are managed. Current practice limits the ability of the National Assembly to examine the final accounts for reliability, accuracy, completeness and compliance with rules. It also prevents a meaningful debate on the extent to which the budget was used for the purposes stated in the approved budget. 


\section{6) Audits on Parliament's request}

There is no legal provision that explicitly enables (or prevents) the Parliament to request audits.

On one occasion, at the sitting of the Security Services Control Committee, Committee Chair proposed that the SAI should initiate a financial audit of the Security Information Agency and such an audit was performed in the following year.

\section{7) Work programme}

During the development of the Strategic Plan 2016 - 2020, the SAI interviewed MPs of the Committee and Subcommittee about their expectations from SAI in the next strategic period. SAl took these inputs into serious consideration.

\section{8) Level and frequency of contacts}

There is regular contact between the head of the SAI and the Chair of competent committee in Parliament on monthly basis. There are a day to day working level contacts between secretary of the Committee and Subcommittee and the Head of the Office of the President.

\section{9) Good practice}

The SAI organised several workshops, round tables, conferences and study visits aimed at strengthening its relations with the Parliament.

Under the Twinning Project "Strengthening Capacities of the State Audit Institution of the Republic of Serbia", guidelines were prepared for relations with the Parliament, auditees and media.

\section{0) Perspective}

As part of the public financial management reform programme $2016-2020$, it is planned to improve systematic follow-up of the implementation of audit recommendations. This will include setting up a database of audit recommendations, facilitating the identification of systems issues and enhancing the information basis for Parliamentary oversight over the executive. It will also ensure a proper Parliamentary oversight function. This will include making the necessary organisational arrangements to cover external audit work, and setting clear written procedures for discussion of audit reports, including deadlines for discussion and action for Committee for Finance, State Budget and Control of Public Spending. It will also cover organising meetings of the Committee for Finance, State Budget and Control of Public Spending for discussion of audit reports.

11) Are there any other relevant features of the current relations between the SAI and Parliament that you would like to highlight, and how have they evolved over the past five years?

President of the State Audit Institution and Vice President of the National Assembly, the Chair of the Committee for Finance, State Budget and Control of Public Spending, signed a Memorandum of Understanding between the Committee and the SAI on 10 June 2015. 


\section{SLOVAK REPUBLIC}

Supreme Audit Office

\section{1) Legal framework}

\section{Constitution of the Slovak Republic:}

Article 62:

The Supreme Audit Office shall submit reports on the results of its auditing activity to the National Council of the Slovak Republic at least once a year and whenever requested to do so by the National Council of the Slovak Republic.

\section{Act on SAO SR:}

Article 5:

(1) The Office shall elaborate its opinion on the proposal for the State budget of the Slovak Republic, in which it also evaluates the proposal for the budget of the State administration, and its opinion on the proposal for the final state account of the Slovak Republic. The Office shall submit its opinion on the proposal for the State budget of the Slovak Republic to the National Council of the Slovak Republic within the time period given by special regulation. 1e) The Office shall submit its opinion on the proposal of the final state account of the Slovak Republic to the National Council of the Slovak Republic within 30 days following the Government's decision.

(2) The Office shall perform the tasks of a body issuing declarations on winding-up of assistance granted under Structural Funds 1f) and the tasks of the body issuing declarations on the winding-up of assistance granted under the Cohesion Fund $1 \mathrm{~g}$ ); it shall be responsible for the content of such declarations and shall submit them to the competent authorities.

(3) The Office shall perform the tasks of certifying body for the European Agricultural Guidance and Guarantee Fund - Guarantee Section. 1h).

(4) Based on a resolution of the National Council of the Slovak Republic, the Office shall carry out an audit within the scope of its competence for the purposes of the National Council of the Slovak Republic.

(5) No later than the end of March of the following year, the Office shall submit to the National Council of the Slovak Republic a summary report on the results of audit activity for the previous calendar year. The report on the results of audit activity shall be submitted whenever requested by the National Council of the Slovak Republic.

Article 8:

(1) The Office shall be headed by the President as a statutory body. The President shall be deputised by the designated Vice-President.

(2) The President and two Vice-Presidents shall be elected and recalled by the National Council of the Slovak Republic by secret ballot. 
(3) The term of office for the President and the two Vice-Presidents shall be seven years.

(4) The President and the two Vice-Presidents may be elected to their offices for no more than two consecutive terms of office.

(5) The President shall remain in his or her office after the completion of his or her term of office until a new President has been elected by the National Council of the Slovak Republic.

Article 12:

(1) The office of the President and the Vice-Presidents shall be terminated by:

a) expiration of the official term, unless otherwise provided by this Act;

b) resignation;

c) recall from the office.

(2) The President or Vice-President shall be recalled from the office by the National Council of the Slovak Republic when:

a) he or she has been lawfully convicted of an intentional crime;

b) he or she has held an office or performed activity incompatible with the office of the President or Vice-President under the Article 10;

c) he or she does not performed duties laid down by this Act.

(3) The National Council of the Slovak Republic can recall the President or Vice-President if he or she has not performed the duties of their office for a period exceeding six consecutive calendar months.

Article 13:

(1) The President shall inform the National Council of the Slovak Republic and other respective bodies on important findings and information resulting from the scope of competence of the Office.

Article 14:

The President holds the right to be present at sessions of the National Council of the Slovak Republic and its bodies.

Article 20:

In the case of the Government's failure to fulfil its obligations under the paragraph 2, the President shall consult the matter with the Prime Minister. When no agreement can be reached by them, the President shall refer the matter to the National Council of the Slovak Republic.

Article 21a:

(1) Budget of the Office forms a separate budget chapter in the State budget of the Slovak Republic. 
(2) The Office shall submit a draft of the budget chapter for approval to the competent committee of the National Council of the Slovak Republic. The competent committee of the National Council of the Slovak Republic shall submit the approved draft of the budget chapter to the Office of the Government by 30 June of the current year. The Government shall decide on the draft of the budget chapter of the Office. If the Government makes any changes in the draft of the budget chapter of the Office, it shall give reasons for such changes upon the time when the bill on the State budget is submitted to the National Council of the Slovak Republic.

(3) The Office is accountable to the National Council of the Slovak Republic for the management of the State budget funds under the budget chapter of the Office.

(4) The National Council of the Slovak Republic shall control the management of the State property, including the State budget funds under the budget chapter of the Office, by the Office.

\section{2) SAI reporting practices}

The Supreme Audit Office (SAO) submits audit reports on individual audits separately to relevant Parliament committees. The other kind of reports to the National Council of the Slovak Republic are:

- a summary report on the results of audit activity for the previous calendar year no later than the end of March;

- an opinion on the proposal for the State budget of the Slovak Republic within the time period given by special regulation;

- an opinion on the proposal of the final State account of the Slovak Republic to the National Council of the Slovak Republic within 30 days following the Government's decision.

\section{Procedures for sending reports to Parliament}

There are no specific procedures for sending audit reports to Parliament. Opinions on the proposal for the State budget and on the proposal of the final State account are presented personally to the Budgetary Committee of the Parliament and finally to the Parliament plenary session by the SAO President. 
Number and type of reports

\begin{tabular}{|c|c|c|c|c|c|c|c|}
\hline & $\begin{array}{l}\text { Financial } \\
\text { audit } \\
\text { reports }\end{array}$ & $\begin{array}{l}\text { Compliance } \\
\text { audit reports }\end{array}$ & $\begin{array}{l}\text { Performance audit } \\
\text { reports }\end{array}$ & $\begin{array}{l}\text { Other reports } \\
\text { or documents }\end{array}$ & $\begin{array}{l}\text { Annual } \\
\text { activity } \\
\text { reports }\end{array}$ & $\begin{array}{l}\text { Reports at } \\
\text { request of } \\
\text { Parliament }\end{array}$ & Remarks \\
\hline Number submitted & \multicolumn{3}{|c|}{30} & 2 & 1 & & \\
\hline $\begin{array}{c}\text { Number discussed } \\
\text { by Parliament }\end{array}$ & & & & 2 & 1 & & \\
\hline \multicolumn{8}{|l|}{$\begin{array}{l}\text { Submitted to } \\
\text { Speaker }\end{array}$} \\
\hline \multicolumn{8}{|l|}{$\begin{array}{l}\text { Submitted to Chair } \\
\text { of dedicated } \\
\text { committee }\end{array}$} \\
\hline $\begin{array}{l}\text { Copied to other } \\
\text { relevant } \\
\text { committees }\end{array}$ & \multicolumn{3}{|c|}{30} & & & & \\
\hline \multicolumn{8}{|l|}{$\begin{array}{l}\text { Briefings organised } \\
\text { for Parliamentary } \\
\text { committee }\end{array}$} \\
\hline $\begin{array}{l}\text { Summaries } \\
\text { submitted to } \\
\text { Parliament }\end{array}$ & & & & & & & \\
\hline
\end{tabular}

\section{3) Parliamentary procedures for SAI reports}

There are fixed procedures for handling SAI reports laid down in Parliament's rules of procedure. However, the procedures are the same as any other reports submitted to Parliament. There is no special dedicated committee for handling with SAI audit reports. The SAO usually submits all audit reports on individual audits to relevant Parliament committee, depending on the subject of audit.

There are rarely hearings to which the auditees or other appropriate persons are invited to provide clarification or further information, and only in very important cases. It is not normal procedure.

A Parliamentary resolution is issued with a relevant conclusion which depends on specific matter.

\section{Staffing}

There is no specific Parliamentary committee dealing with audit reports. Each committee has about 12 members. Staff of the Parliament provide only administrative support to the committee(s). However, each Member of Parliament has external advisers to provide special assistance and support. 


\section{SAl involvement in consideration of reports by Parliament}

The SAO always attend Parliamentary meetings of the Budgetary Committee to present an opinion on the proposal for the State budget and an opinion on the proposal of the final State account. The Budgetary Committee of the Parliament is the relevant committee in this matter. The SAO is usually represented by the Vice President and Director General responsible for the opinion.

\section{4) SAI reports}

The SAO focuses on generic/systemic problems and recommendations in its communications to Parliament.

The set up and functioning of internal control systems is a subject that is highlighted in SAO reports.

All audit reports contain clear conclusions and audit opinions.

\section{5) Follow-up on SAI reports}

The Act on the SAO sets the obligation for the auditees to submit to the SAO the remedial measures and report on fulfilling remedial measures for each audit to the agreed deadline, documented in the minutes of the closing of each audit.

Approach of the SAO to the follow-up is to review on the spot the remedial measures and recommendations within the audit, if relevant. Separate audits focus specially on the follow-up, and monitoring of the remedial measures and recommendations take place via audit information systems.

\section{6) Audits on Parliament's request}

Based on a resolution of the National Council of the Slovak Republic, the SAO may carry out an audit within the scope of its competence when requested by the National Council of the Slovak Republic. Such case arise very rarely, maybe 1 - 2 times in 2 - 3 years.

\section{7) Work programme}

The SAO does not consult on its annual audit plan with the Parliament. The SAO evaluates very closely all accessible public suggestions and proposals, including the Parliament's views, during the annual planning process. Parliament's suggestions and proposals are not binding, but we evaluate them.

\section{8) Level and frequency of contacts}

There is no regular contact between the President of the Office and the Chairs of committees in Parliament. Formal contacts arise from the statutory responsibilities of the SAO to submit its reports. There are no SAO staff or unit within the SAO Office specifically empowered and tasked with Parliamentary relations.

\section{9) Good practice}

The SAO does not wish to highlight anything. 


\section{0) Perspective}

The main intention of the SAO for the future is to intensify the contacts with relevant committees of the Slovak Parliament, the National Council of the Slovak Republic. As well as formal meetings we would like to introduce informal meetings with a goal to discuss topics of the concern of both sides.

11) Are there any other relevant features of the current relations between the SAI and Parliament that you would like to highlight, and how have they evolved over the past five years?

Relations of the Slovak SAO and Slovak Parliament within past five years have been good. The SAO carried out couple of audits based on the request of the Slovak Parliament. 


\section{SLOVENIA}

Court of Audit

\section{1) Legal framework}

The Constitution of the Republic of Slovenia has two Articles on the Court of Audit (CoA), Articles 150 and 151. It defines the CoA as independent in performance of its duties and bound by the Constitution and the laws (paragraph 3 Article 150) which states Members the CoA are appointed by the National Assembly (Article 151).

The CoA's obligations to Parliament (Official Gazette Republic Slovenia, No. 11/01 and 109/12) stipulates the following:

- At least once a year, the Court of Audit shall submit a report on its work to the National Assembly for its consideration. (paragraph 2 Article 5)

- The report referred to in Article 5, paragraph 2, of this Act must contain: a list of all audit proposals made by Deputies and working bodies of the National Assembly;

- clear evidence as to which audits have taken into account these proposals. (paragraph 3 Article 25)

- In determining the audits to be carried out in a certain calendar year, the Court of Audit shall consider proposals made by Deputies and working bodies of the National Assembly, Government, ministries and local community bodies. They must consider at least five proposals from the National Assembly from which at least two must be given by opposition Deputies and a further two by working bodies of the National Assembly. (paragraph 2 Article 25).

- Upon the completion of the audit process the audit report shall be delivered to:

$\circ$ the auditee;

- the auditee's officer who was responsible in the period covered by the audit;

0 the National Assembly;

- other authorities which, in the opinion of the President of the Court of Audit, should be informed of the audit disclosures. (paragraph 16 Article 28).

- In the post-audit procedure, if the requirement for operational efficiency has been seriously violated, the Court of Audit shall notify the National Assembly. (paragraph 8 Article 29).

\section{2) SAI reporting practices}

The CoA is bound by the law to deliver audit reports to the National Assembly upon completion. This is the case for all types of audit reports (financial, compliance, performance, post-audit reports). The National Assembly receives the audit report in their original form, with no special additions or summaries drawn up for the National Assembly.

The reports are addressed to the National Assembly in general, not to a specific person or body. As each report must be submitted to the National Assembly upon its completion, they are sent to them at the same time as to the auditee(s), immediately. 
The CoA also sends once a year to the National Assembly its annual report. It is usually published at the end of February and there is no deadline for sending it to the National Assembly. The report is usually personally handed by the President of the CoA to the Speaker of the National Assembly.

\section{Procedures for sending reports to Parliament}

There are no specific procedures in place. A copy of the audit report is sent to the National Assembly at the same time as it is to the auditee.

The CoA does not undertake any other activities unless invited to do so by the National Assembly or its bodies.

\section{Number and type of reports}

\begin{tabular}{|c|c|c|c|c|c|c|c|}
\hline & $\begin{array}{l}\text { Financial } \\
\text { audit } \\
\text { reports }\end{array}$ & $\begin{array}{l}\text { Compliance } \\
\text { audit reports }\end{array}$ & $\begin{array}{c}\text { Performance audit } \\
\text { reports }\end{array}$ & $\begin{array}{l}\text { Other reports } \\
\text { or documents }\end{array}$ & $\begin{array}{l}\text { Annual } \\
\text { activity } \\
\text { reports }\end{array}$ & $\begin{array}{l}\text { Reports at } \\
\text { request of } \\
\text { Parliament }\end{array}$ & Remarks \\
\hline Number submitted & $30(45 \%)$ & $16(25 \%)$ & $18(28 \%)$ & $\begin{array}{l}\text { 1(summary } \\
\text { report) }\end{array}$ & 1 & Not applicable & \\
\hline $\begin{array}{c}\text { Number discussed } \\
\text { by Parliament }\end{array}$ & 3 & 5 & 12 & 0 & \begin{tabular}{|c|} 
Not \\
applicable
\end{tabular} & Not applicable & \\
\hline $\begin{array}{l}\text { Submitted to } \\
\text { Speaker }\end{array}$ & $\begin{array}{c}\text { Not } \\
\text { applicable }\end{array}$ & Not applicable & Not applicable & Not applicable & $\begin{array}{c}\text { Not } \\
\text { applicable }\end{array}$ & Not applicable & \\
\hline $\begin{array}{l}\text { Submitted to Chair } \\
\text { of dedicated } \\
\text { committee }\end{array}$ & $\begin{array}{c}\text { Not } \\
\text { applicable }\end{array}$ & Not applicable & Not applicable & Not applicable & \begin{tabular}{|c|} 
Not \\
applicable
\end{tabular} & Not applicable & \\
\hline $\begin{array}{l}\text { Copied to other } \\
\text { relevant } \\
\text { committees }\end{array}$ & $\begin{array}{c}\text { Not } \\
\text { applicable }\end{array}$ & Not applicable & Not applicable & Not applicable & \begin{tabular}{|c|} 
Not \\
applicable
\end{tabular} & Not applicable & \\
\hline $\begin{array}{l}\text { Briefings organised } \\
\text { for Parliamentary } \\
\text { committee }\end{array}$ & $\begin{array}{c}\text { Not } \\
\text { applicable }\end{array}$ & Not applicable & Not applicable & Not applicable & \begin{tabular}{|c|} 
Not \\
applicable
\end{tabular} & Not applicable & $\begin{array}{c}\text { CoA attends } \\
\text { briefings if } \\
\text { organised } \\
\text { by the } \\
\text { National } \\
\text { Assembly }\end{array}$ \\
\hline $\begin{array}{l}\text { Summaries } \\
\text { submitted to } \\
\text { Parliament }\end{array}$ & $\begin{array}{c}\text { Not } \\
\text { applicable }\end{array}$ & Not applicable & Not applicable & Not applicable & \begin{tabular}{|c|} 
Not \\
applicable
\end{tabular} & Not applicable & $\begin{array}{l}\text { Summary of } \\
\text { the audit } \\
\text { report is } \\
\text { part of the } \\
\text { audit report } \\
\text { published }\end{array}$ \\
\hline
\end{tabular}




\section{3) Parliamentary procedures for SAI reports}

After completion, the audit report is published and simultaneously sent to the auditee(s) and the National Assembly. There are no specific rules for handling the SAI reports. However, the reports are, once received by the National Assembly, forwarded to the Commission for Public Finance Control (CPFC). The Commission is a permanent working body with nine members, chaired by a member of the opposition. Its mandate, tasks and composition are regulated by the Rules of Procedure of the National Assembly in Article 39.

CPFC organises a hearing, and can invite the CoA and auditee(s) when an audit report is discussed, for clarification or further information. The Commission can also use external experts if it considers it necessary. However, such expert examinations are not and cannot be a supervision of the audit reports of the CoA.

The debate on SAI reports is usually held with the Commission but it can also be held in the Plenary. This last option is considered as a special vehicle.

Apart from the CPFC the audit reports of the CoA can and are also considered by other commissions, for example commission on EU Affairs, Agriculture, and Infrastructure, to name a few. Sometimes the CoA audit reports are considered and the CoA invited to ad hoc sessions of the Commission dealing with a specific subject matter of special importance to the National Assembly.

CPFC publishes minutes of each session in which conclusions as well as requests for action are included. These requests can be addressed to the auditees or bodies, but not to the CoA.

The role of National Assembly in Slovenia on the discharge procedure is that it adopts the annual report on budget execution. The CoA plays no role in this procedure.

\section{Staffing}

No Parliamentary staff are dedicated to supporting the Commission in dealing with the SAI reports specifically.

\section{SAl involvement in consideration of reports by Parliament}

The CoA is not involved in the committee's preparation for the hearings.

The CoA attends the meetings when the reports are debated only upon invitation from the Commission/Assembly. The invitation is extended to the President of the CoA, who usually attends the meetings with other members of the CoA, depending on the audit and subject matter being discussed, Deputy ( or both Deputies), Heads of Audit Departments ( Supreme State Auditors), Audit Managers or Advisers.

The contribution of the representatives of the CoA is limited to the audits performed. Only when a general discussion is open, Members of the CoA (President, First and Second Deputy) would share observations based on the findings in also other relevant audits performed, pertaining to the issue or policy being discussed. 


\section{4) SAI reports}

The CoA focuses on generic/systemic problems and makes recommendations, which, are not binding for the auditee(s). They are only an expression of the CoA's view on the issue.

Set up and functioning of the internal controls is not a subject that would be highlighted in the reports, however the CoA does make recommendations on internal controls (especially on detecting risks and irregularities).

Clear conclusion and formulation of an audit opinion is obligatory for all types of audits in Slovenia. The Court of Audit Act stipulates in Article 20:

1. The Court of Audit shall audit the business operation of users of public funds:

a) it may carry out regularity and performance audits;

b) it may audit any act on past operations as well as any act on planned business operation of any user of public funds.

2. Auditing of business operation under this Act shall be the obtaining of relevant and sufficient data to express an opinion on the business operation of the auditee:

a) Regularity audits provide relevant and sufficient data to enable an opinion to be expressed on compliance of operation with regulations and guidelines that any user of public funds is required to observe in the conduct of business operation;

Performance audits provide relevant and sufficient data to enable an opinion to be expressed on economy, efficiency and effectiveness of business operation.

\section{5) Follow-up on SAI reports}

The CoA keeps very good track of conclusions and recommendations accepted by auditees, since in Slovenia the COA has the power to issue not only non-binding recommendations, but also requests for action, which are binding on the auditee and their fulfilling is verified in the post-audit procedure though the response report which the auditee must submit about the actions taken.

Since the post-audit procedure is to enhance the adherence of the auditee(s) to the requests for action, the CPFC pays attention to the reaction of the auditee(s) to the audit report issued.

The Government has the same status as any other auditee, and is equally obliged to submit a response report on requests for action issued to it in an audit report.

The CoA is not in a position to assess how the recommendations of the CoA are used and input for the annual debate on draft budget.

\section{6) Audits on Parliament's request}

The National Assembly has the right to propose and submit initiatives for audits, but has no power to request or order them. The CoA is fully independent in drawing up its audit plan, but should take into consideration the initiatives received and include them in the plan. 
The Court of Audit Act gives the National Assembly the right to submit proposals in paragraphs 2 and 3 Article 25:

(1) Within the framework set by the law, the Court of Audit shall independently decide which audits they will carry out in any individual period of time.

(2) In determining the audits to be carried out in a certain calendar year, the Court of Audit shall consider proposals made by Deputies and working bodies of the National Assembly, Government, ministries and local community bodies. They must consider at least five proposals from the National Assembly from which at least two must be given by opposition Deputies and a further two by working bodies of the National Assembly.

(3) The report referred to in Article 5, paragraph (2) of this Act must contain:

1. a list of all audit proposals made by Deputies and working bodies of the National Assembly;

2. clear evidence as to which audits have taken into account these proposals.

In 2015 the CoA has received 10 initiatives from the National Assembly: 1 from the Plenary, six from CPFC, and three from individual MPs or MP groups. They have been included in the activities of the CoA at different stages of the audit procedures and in some elements of the annual plan. The decision of how the initiatives are to be included in the annual audit plan is solely that of the President of the CoA.

\section{7) Work programme}

See the previous section.

\section{8) Level and frequency of contacts}

There is regular contact between the President of SAI and the Chair of CPFC, mostly following the CPFC's activities with regard to the audit reports published, but also on a more informal level in discussion on public finance or governance issues.

\section{9) Good practice}

As the CoA sends each report to the National Assembly the moment it is published, the CPFC is up to date with its work and can take the information or issues and concerns raised in the reports either to its sessions or to the Plenary.

Another good example is also the handing over of the CoA's annual report to the Speaker of the Parliament, when the President of the CoA and the Speaker of the National Assembly discuss the impact of the SAl's work, highlight areas of common interest and identify possible points of further development of the co-operation.

\section{0) Perspective}

The CoA believes it has a good regular working relationship with the National Assembly, which enables both institutions to jointly develop further elements of their co-operation, address relevant issues of the time, and to employ the potential of both of them in addressing issues of public finance and governance to the benefit of Slovene society. 
SPAIN

Court of Auditors

\section{1) Legal framework}

The Tribunal de Cuentas (SAI of Spain) reports directly to the Spanish Parliament and is in permanent liaison with it through the Joint Congress-Senate Committee for relations with the Tribunal de Cuentas.

The Spanish Parliament has a legal right to request the Tribunal de Cuentas to carry out specific audits, by decisions of the Joint Commission for relations with the Tribunal de Cuentas. The Court must incorporate these initiatives into its audit programme, taking into account its availability of resources. Please see also section 136 of the Spanish Constitution.

The Full Session of the Tribunal de Cuentas approves the audit programme each year and sends it to the Joint Committee for relations with the Tribunal de Cuentas.

The result of audit actions is included in reports, memoranda, motions and memos approved by the Full Session of the Tribunal de Cuentas, which are sent to the Spanish Parliament.

The President of the Tribunal de Cuentas regularly presents to Parliament the reports approved and issued by the Tribunal de Cuentas throughout the year, as those reports are approved by the Full Session at its regular meetings. An annual report is also presented.

Following the hearing the President of the Tribunal de Cuentas, the Joint Congress-Senate Committee for relations with the Tribunal de Cuentas deliberates on each of the reports, memoranda, motions and memos, taking the appropriate decisions (for more information, please see the Organic Act and the Functioning Act of the Tribunal de Cuentas).

\section{2) SAI reporting practices}

The Tribunal de Cuentas sends to Parliament all the reports approved and issued, whether they are financial, compliance, performance audit reports or memoranda, motions and memos.

The Tribunal de Cuentas reports separately on individual audits, but it also reports on the general State accounts, which includes audit work related to many entities.

The Spanish Tribunal de Cuentas approves and sends to Parliament an annual report of its activities. Reports are addressed to the Presidents of the Congress and of the Senate.

The Annual audit programme is addressed to the Chair of the Joint Committee.

Article 132 of the General Budgetary Act (examination and verification of the general State accounts) states that by delegation of the Parliament, the Tribunal de Cuentas shall examine and verify the General Account of the State within six months following its reception. The Court, following a hearing of the Prosecutor, shall enact the definitive declaration as it sees fit and send the account to Parliament with its proposal, while concurrently informing the Government.

The General Account of the State is drafted by the General Comptroller of State and sent to the Spanish Tribunal de Cuentas by 31 October of the following year. 
Other audit reports have no standard deadline, but internal deadlines are set in the technical directives of the specific audits.

\section{Procedures for sending reports to Parliament}

The Tribunal de Cuentas has no specific procedures for sending its reports to Parliament.

The President presents all reports to the Parliamentary Committee. In the last year, 19 audit reports have been submitted and 23 have been discussed by Parliament.

\section{3) Parliamentary procedures for SAI reports}

There are fixed procedures for handling the reports of the Tribunal de Cuentas laid down in two rules of the Joint Committee. It is also interesting to consult the Standing Orders of the Congress.

The Joint Committee is usually chaired by a deputy of the ruling party, usually as a result of political negotiations.

The Committee does not appoint a rapporteur. Auditees and other appropriate persons are not invited to provide clarification or further information. The Committee does not use independent external experts in examining reports, request additional information or clarification in writing from appropriate persons.

The debate on Tribunal de Cuentas reports is held in the Joint Committee. Other committees do not usually consider the reports of the CoA.

At the end of the debate on an audit report, a resolution is published in the official gazette together with the report itself.

\section{Staffing}

The Joint Committee is supported by one member of staff with a legal background. No written research, analysis or briefings are provided in preparation for debates on Tribunal de Cuentas reports.

\section{SAl involvement in consideration of reports by Parliament}

The President of the Tribunal de Cuentas regularly presents to Parliament the reports approved and issued by the Court throughout the year, as those reports are approved by the Full Session at its regular meetings.

The Tribunal de Cuentas has no involvement in the committee or parliaments preparation for hearings. The President of the Tribunal de Cuentas, the Chief of Cabinet of its Presidency and its Director of Communication attend relevant hearings.

\section{4) SAI reports}

The Tribunal de Cuentas focuses both on generic/systemic problems and recommendations in its communications to Parliament, depending on the scope and perspective set in the Annual Audit Programme and the Audit Technical Guidelines approved for each report. The internal control system can be a subject highlighted in SAI reports.

Finally, audit reports have a common structure, including clear conclusions and audit opinions. 


\section{5) Follow-up on SAI reports}

The follow-up of conclusions and recommendations of previous audit reports can be planned in the following Annual Audit Programmes. The Tribunal de Cuentas keeps track of conclusions and recommendations accepted by auditees. Parliament pays attention to the implementation of recommendations in audit reports.

The Tribunal de Cuentas reports specifically on the implementation/non-implementation of recommendations, including those in respect of the set up and functioning of internal control systems, and this stimulates parliamentary follow-up.

The Government is not required to report on the implementation of the Tribunal de Cuentas recommendations.

Reports of the Tribunal de Cuentas are not regularly used as input for the annual debate on draft budgets.

\section{6) Audits on Parliament's request}

According to section 45 of the Organic Act, procedures for performance of the auditing function shall be initiated ex officio at all stages. Proceedings may be initiated by the Tribunal de Cuentas itself, the Parliament, and, within their spheres of responsibility, the regional Legislative Assemblies.

\section{7) Work programme}

The Tribunal de Cuentas does not consult Parliament on its annual Work programme of audits.

\section{8) Level and frequency of contacts}

Usually there are formal contacts at hearings. Occasional contacts are possible among the Ruling Committees of the Court and the Joint Committee.

There are informal contacts between the Chief of Cabinet of the Presidency of the Court and the lawyer of the Joint Committee. Chief of Cabinet is specifically tasked with Parliamentary relations.

\section{9) Good practice}

Audit reports are published in the Tribunal de Cuentas website. Press releases are issued by the Tribunal de Cuentas on the reports.

\section{0) Perspective}

There are sometimes delays in the presentation of the reports, as a consequence of Parliamentary agenda set by the Joint Commission, and in the Parliament monitoring process of its own resolutions. 
SWEDEN

National Audit Office

\section{1) Legal framework}

The scope and focus of the audit is governed by the Act on Audit of State Activities, and by the Act containing Instructions for the Swedish National Audit Office.

The Instrument Government, (Chapter 13):

"The National Audit Office is an authority under the Riksdag (Parliament) whose function is to audit the activities of the State. Provisions stating that the National Audit Office's audit may extend also to activities other than activities of the State are laid down in law."

"The National Audit Office is under the direction of three Auditors General, who are elected by the Riksdag. The Riksdag may remove an Auditor General from office only provided the Auditor General no longer fulfils the requirements for the office or has been guilty of gross negligence. The Auditors General decide independently, having regard to the rules laid down in law, what activities shall be audited. They determine separately and independently how their audit shall be carried out and draft their own conclusions on the basis of their audit."

\section{2) SAI reporting practices}

Financial Audits result in auditor's reports on financial statements that the Swedish National Audit Office (SNAO) submits to the Government and to the audited authority. The SNAO also gives verbal reports to the authorities and ministries concerned.

Performance Audits result in reports submitted to the Riksdag, who in turn submit them to the Government. The Government must report on measures it has taken, or intends to take, within four months. The committee concerned then considers the document, and the Riksdag makes a decision in the case.

The SNAO submits its annual report to the Riksdag, together with its financial report. In the annual report, a comprehensive assessment is also given on SNAO activities and set goals. The most significant observations are also included in the annual report of the Auditors General.

In the follow-up report the SNAO annually follows-up on actions taken according to findings and recommendations in the audit reports.

\section{Procedures for sending reports to Parliament}

For each term of office, the Parliament appoints a Parliamentary Council for the SNAO. The Council consists of one MP from each party. The Parliamentary Council works to ensure transparency of the national audit activities. The Council follows the activities of the SNAO, who present its audit activities and results to the Council.

The SNAO also presents the performance audit reports to the committees concerned, when asked by the committee. 
Number and type of reports

\begin{tabular}{|c|c|c|c|c|c|c|c|}
\hline & $\begin{array}{l}\text { Financial } \\
\text { audit } \\
\text { reports }\end{array}$ & $\begin{array}{l}\text { Compliance } \\
\text { audit reports }\end{array}$ & $\begin{array}{c}\text { Performance audit } \\
\text { reports }\end{array}$ & $\begin{array}{l}\text { Other reports } \\
\text { or documents }\end{array}$ & $\begin{array}{l}\text { Annual } \\
\text { activity } \\
\text { reports }\end{array}$ & $\begin{array}{l}\text { Reports at } \\
\text { request of } \\
\text { Parliament }\end{array}$ & Remarks \\
\hline Number submitted & 3 & Not applicable & 25 & 3 & 1 & Not applicable & \begin{tabular}{|c|} 
Financial \\
Audit is \\
mainly \\
reported to \\
Government
\end{tabular} \\
\hline $\begin{array}{l}\text { Number discussed } \\
\text { by Parliament }\end{array}$ & 3 & Not applicable & 25 & & 1 & Not applicable & \\
\hline $\begin{array}{l}\text { Submitted to } \\
\text { Speaker }\end{array}$ & $\mathrm{N}$ & Not applicable & $\bar{Y}$ & $\mathrm{~N}$ & $\bar{Y}$ & Not applicable & \begin{tabular}{|c|} 
To the \\
Speaker, \\
then to the \\
relevant \\
committee
\end{tabular} \\
\hline $\begin{array}{c}\text { Submitted to Chair } \\
\text { of dedicated } \\
\text { committee }\end{array}$ & 3 & Not applicable & 25 & $Y$ & $\mathrm{Y}$ & Not applicable & As above \\
\hline $\begin{array}{l}\text { Copied to other } \\
\text { relevant } \\
\text { committees }\end{array}$ & $\mathrm{N}$ & Not applicable & $\mathrm{Y}$ & $\mathrm{N}$ & $\mathrm{Y}$ & Not applicable & \\
\hline $\begin{array}{l}\text { Briefings organised } \\
\text { for Parliamentary } \\
\text { committee }\end{array}$ & $\bar{Y}$ & Not applicable & $\bar{Y}$ & $Y$ & $\bar{Y}$ & Not applicable & $\begin{array}{c}\text { As by } \\
\text { request. The } \\
\text { Committee } \\
\text { calls the } \\
\text { SNAO when } \\
\text { deemed } \\
\text { necessary. }\end{array}$ \\
\hline $\begin{array}{l}\text { Summaries } \\
\text { submitted to } \\
\text { Parliament }\end{array}$ & $\mathrm{N}$ & Not applicable & $\bar{Y}$ & $\mathrm{~N}$ & $\mathrm{~N}$ & Not applicable & \\
\hline
\end{tabular}

\section{3) Parliamentary procedures for SAI reports}

The procedures are to a great extent regulated in law. There is however, within the limits of the regulation, a variety of possibilities for the standing committees in handling the reports.

The reports are handled by the relevant standing committees, depending on which subject or policy area the report covers.

There may be hearings with the auditees. Sometimes the SNAO participates. 
Debates can be held both in the standing committee and in plenary.

The committee responsible for handling the report can invite other standing committees to comment on the report.

The Parliament sends the report to the Government. The Government answers to the report to Parliament, the report from the SNAO is annexed to the written communication. The written communication is discussed in a standing committee. The committee draws up a report containing its proposal as to what decision the Chamber should take on the matter. This is later discussed in plenary and a decision is taken.

\section{SAl involvement in consideration of reports by Parliament}

The SNAO does not participate in the preparation.

The Auditor General is usually asked to report to the Committee. The Auditor General is accompanied by the project leader. This does not mean that the SNAO participates in the debate/preparation of the report.

\section{4) SAI reports}

The SNAO reports on any findings made in the audit. The internal control systems can be one aspect.

Reports contain conclusions and most reports contain recommendations.

\section{5) Follow-up on SAI reports}

For financial audit, findings are followed up as part of next year's audit.

Regarding performance audit, the SNAO is not explicitly responsible for keeping track on actions taken. Instead Government is obliged to report to Parliament on measures taken.

The SNAO submits an annual follow-up report covers the actions taken on a number of audit reports.

\section{6) Audits on Parliament's request}

The SNAO does not receive requests from Parliament.

The SNAO has a variety of contacts with Parliament, the standing committees and the Parliamentary Council for the SAI. In these contacts, the SNAO of course raise interesting subjects for audit. It is, however, always the Auditors General that decide on what to audit.

\section{7) Work programme}

Please see above. The SNAO is obliged to inform the Parliamentary Council on the annual audit plan before it is decided.

\section{8) Level and frequency of contacts}

There are contacts at all organisational levels.

There is an officer coordinating the SNAO's contacts with Parliament. 


\section{9) Good practice}

After every general election (every fourth year) the Swedish NAO invites all standing committees for a presentation about the SNAO. This helps the Parliamentarians' general understanding of the SNAO's role and also opens up for easier personal access to the SNAO.

Staff from the SNAO are sometimes seconded to the standing committees in order to create a better mutual understanding.

10) Are there any other relevant features of the current relations between the SAI and Parliament that you would like to highlight, and how have they evolved over the past five years?

Engaging and collaborating with Parliament increases the knowledge and understanding of our fields of operation. For example, inviting Parliamentarians after each election has been a highly appreciated initiative. 


\section{TURKEY}

Court of Accounts

\section{1) Legal framework}

\section{Audit and Reporting}

As the Constitution states, the Turkish Court of Accounts (TCA) audits the financial activities, decisions and transactions of public administrations within the framework of accountability and submits accurate, sufficient, timely information and reports to the Turkish Grand National Assembly (TGNA) on the results of these audits.

The TCA perform audit activities on behalf of the TGNA. Audit is carried out to submit reliable and sufficient information to the TGNA and the public on the activity results of public administrations, as required by the power of the purse. In this framework TCA is required to submit its reports to the TGNA, except for the reports on local administrations.

\section{Communication on the SAI's work plan}

TCA prepares its audit strategic plans and annual audit programmes in line with a risk analysis in consideration with the expectations of the TGNA, the public and the public administrations subject to audit.

\section{Audit demands from the TGNA}

Upon the decision of the TGNA Research, Investigation and Specialisation Committees, if the audit is limited to the requested subject, the Presidency of TGNA may demand the TCA audit the accounts and transactions of all public institutions and organisations, regardless of whether they are subject to audit. This includes privatisation, incentive, loan and credit implementation. This also applies to the accounts and transactions of any institution, organisation, fund, enterprise, company, co-operative, union, foundation, association or similar enterprise using public resources. The results of audits are be submitted to the Presidency of the TGNA. Audit demands of the TGNA have priority.

\section{2) SAI reporting practices}

The TCA sends mainly two types reports to the TGNA:

\section{A) General Reports}

1) The statement of general conformity is the report on the assessment of reliability and accuracy of financial tables and documents included in the draft final accounts prepared by the Ministry of Finance. It compares the implemented results of the general government budget law included in the draft final account law with the results obtained from the public entity accounts. This report is given to the Speakership of the TGNA to be discussed by the Planning and Budget Committee. The Deadline for submission of this report: 13 September.

2) The external audit general evaluation report is the report on matters that are deemed material or constitute generality in the audit reports prepared at the end of the audits of public entities. It also includes general information about the audits conducted; and other issues deemed appropriate for 
expressing in financial matters. This report is given to the Speakership of the TGNA to be discussed by the Planning and Budget Committee. The Deadline for submission of this report: 13 September.

3) The Accountability General Evaluation Report is prepared by the TCA evaluating accountability reports sent by public administrations, the local government's general accountability report prepared by the Ministry of the Interior and the General Accountability Report prepared by the Ministry of Finance by considering audit results. The accountability general evaluation report is prepared by the TCA. This report is given to the Speakership of the TGNA to be discussed by the Planning and Budget Committee. The Deadline for submission of this report: 13 September.

4) The financial statistics evaluation report is prepared as a result of the assessment of the financial statistics published by the Ministry of Finance for a specific year in terms of preparation, publication, accuracy, reliability and compliance with pre-determined standards.

This report is given to the Speakership of the TGNA to be discussed by the Planning and Budget Committee. Deadline for submission of this report: 13 September.

5) State Economic Enterprises General Report is the report where all the audited public enterprises are addressed in terms of their annual activity results, place in the Turkish economy, employment situation, financial situation, business activities, investments and subsidiaries as well as their general and common problems on the basis of the respective sector. This report is given to the Speakership of the TGNA to be discussed by the State Economic Enterprises Committee.

B) Institutional Audit Reports are produced based on annual institutional audits performed by the TCA.

They cover regularity audit (financial audits and compliance audits) and performance audits (audit of performance indicators) in some cases. These individual reports, except for reports on local administrations, are given to the Speakership of the TGNA to be discussed by the Planning and Budget Committee. These reports are examined in the course of budget negotiation of public institutions in TGNA.

\section{Procedures for sending reports to Parliament}

Annually, the President of the TCA visits the Speaker of the Parliament to give the reports of the TCA and to give information about the activities and reports of the TCA. All TCA reports are published on its website. 


\section{Number and type of reports}

\begin{tabular}{|c|c|c|c|c|c|c|c|}
\hline & $\begin{array}{c}\text { Financial } \\
\text { audit } \\
\text { reports }\end{array}$ & $\begin{array}{c}\text { Compliance } \\
\text { audit reports }\end{array}$ & $\begin{array}{c}\text { Performance audit } \\
\text { reports }\end{array}$ & $\begin{array}{c}\text { Other reports } \\
\text { or documents }\end{array}$ & $\begin{array}{c}\text { Annual } \\
\text { activity } \\
\text { reports }\end{array}$ & $\begin{array}{c}\text { Reports at } \\
\text { request of } \\
\text { Parliament }\end{array}$ & Remarks \\
\hline Number submitted & $545^{*}$ & & $74^{* *}$ & $5 * * *$ & & \\
\hline $\begin{array}{c}\text { Number discussed } \\
\text { by Parliament }\end{array}$ & 211 & 74 & 5 & & \\
\hline $\begin{array}{c}\text { Submitted to } \\
\text { Speaker }\end{array}$ & 211 & 74 & 5 & & \\
\hline $\begin{array}{c}\text { Submitted to Chair } \\
\text { of dedicated } \\
\text { committee }\end{array}$ & 211 & 74 & 5 & & \\
\hline $\begin{array}{c}\text { Copied to other } \\
\text { relevant } \\
\text { committees }\end{array}$ & & & & & \\
\hline $\begin{array}{c}\text { Briefings organised } \\
\text { for Parliamentary } \\
\text { committee }\end{array}$ & & & & & \\
\hline $\begin{array}{c}\text { Summaries } \\
\text { submitted to } \\
\text { Parliament }\end{array}$ \\
*
\end{tabular}

\section{3) Parliamentary procedures for SAI reports}

The principles and procedures governing deliberations at the TGNA on TCA reports are explained in the Internal Regulation of the TGNA. Under Article 20 of Internal Regulation of the TGNA, the Planning and Budget Committee examines and evaluates reports sent by the TCA. No assessment procedures are specified in any documents including Internal Regulation.

There are two committees in TGNA to discuss reports of the TCA. The Planning and Budget Committee examines regularity audit (financial and compliance audits) reports of all the public institutions audited by TCA, except for local administrations. It is chaired by a member of the government party. The State Economic Enterprises Committee examines public enterprises audit reports. It is chaired by a member of the government party. Procedure negotiation is a basis for these Committees.

There is a sub-committee which has appropriate numbers of experts and staffs in State Economic Enterprises Committee. Its main responsibilities are to prepare the agenda for State Economic Enterprises 
Committee and to produce reports of the session of that Committee. This sub-committee serves as a rapporteur for State Economic Enterprises Committee.

Institutional audit reports are examined by the Planning and Budget Committee in the course of the budget negotiations of public institutions, so high management of the public institutions are present in the meetings of the Committee.

When the reports on State Economic Enterprises are discussed the board chair and board members of the State Economic Enterprises take part in the session.

The State Economic Enterprises Committee have authority to request additional information or clarification in writing from appropriate people.

The debate on TCA reports is held in committee meetings. Other committees, apart from dedicated committees, do not have the power of considering the reports of the TCA.

Committee reports, including all of the minutes of the sessions of the Committee, are produced and are published on web sites of the TGNA.

\section{Staffing}

The Budget Department is responsible for supporting the Planning and Budget Committee dealing with TCA reports. However this department has other duties, such as making first examination of draft law. 13 experts and seven administrative staff work for this department.

For the Planning and Budget Committee it is possible for questions to be developed for the committee to ask at hearings.

For the State Economic Enterprises Committee (through the sub-committee previously mentioned), it is possible to provide written research, analysis or briefings in preparation for debates on TCA reports, develop questions for the committee to ask at hearings, and draft reports or other outputs of the committee.

\section{SAI involvement in consideration of reports by Parliament}

In the course of evaluation of the TCA budget, the President of the TCA attends the hearing of the Planning and Budget Committee to inform the members of the Committee about the general activity and reports of the TCA. When TCA reports are debated, Chairs of Chamber, a Head of Department who has responsibility for administration of the TCA, and sufficient numbers of auditors who prepared that audit report are present to provide information if necessary. Generally, if a member of the Committee asks any question which needs information about the report, TCA representative replies to these questions.

For the State Economic Enterprises Committee, when TCA reports are debated; a Head of Department who has responsibility for administration of the TCA, the head of relevant audit group and sufficient numbers of auditors are present to provide information if necessary.

\section{4) SAI reports}

The TCA focuses on both generic and systemic problems and recommendations in its communications with Parliament. 
The set up and functioning of internal control systems is a main subject that is highlighted in TCA reports.

Financial audit reports include audit opinions. The TCA is trying to establish clear conclusions in audit reports.

\section{5) Follow-up on SAI reports}

For the Planning and Budget Committee reports on public institutions in the scope of general government budget law, audit teams keep track of conclusions and recommendations accepted by auditees and progress is reported within the relevant year audit report. Parliament has no mechanism to implement TCA recommendations in these types of audit reports

For the State Economic Enterprises Committee reports on State economic enterprises, relevant audit teams keep track of conclusions and recommendations accepted by auditees. The follow-up is included in audit report as a special section. If it is regarded necessary, the State Economic Enterprises Committee specifically follows up the reports.

\section{6) Audits on Parliament's request}

Upon the decision of the TGNA Research, Investigation and Specialisation Committees, if the audit is limited to the requested subject, the Presidency of TGNA may demand the TCA audit the accounts and transactions of all public institutions and organisations, regardless of whether they are subject to audit including privatisation, incentive, loan and credit implementations. This also applies to the accounts and transactions of any institution, organisation, fund, enterprise, company, co-operative, union, foundation, association or similar enterprise using public resources. The results of audits are submitted to the Presidency of the TGNA. Audit demands of the TGNA have priority.

Preliminary examination of audit requests based on the decision of the TGNA Research, Investigation and Specialisation Committees is carried out by the relevant support group which has been appointed by Presidency. After this preliminary examination, relevant support group submits its assessment and opinion to the Presidency within 10 working days. The preliminary examination determines how the accounts and transactions relate to the audit request, and how it is dealt with in terms of audit principles and procedures, timeline, and budget opportunities, which are explained in SAI law and other legislation clearly.

\section{7) Work programme}

TCA prepares its work program independently from any organisation including TGNA and auditees. It has the authority to specify the audited entities and subjects. This is an indispensable condition for the independence of the TCA, so the TCA never consult any organisation on its Work programme. However, audit demands of the TGNA are given priority to establish the Work programme.

\section{8) Level and frequency of contacts}

For the Planning and Budget Committee, there is contact in the process of budget preparation. The TCA group which is interested in general conformity is present during the budget negotiations in the Committee and General Assembly in the Parliament. The President of the TCA informs the TGNA Planning and Budget Committee at least twice a year, and where necessary, the related committees about the activities of Turkish Court of Accounts. An audit team from the TCA is always present in the TGNA for audit activities of the TGNA. 
For State Economic Enterprises Committee, there is a regular contact with procedures that are set up in an efficient manner on working group level.

\section{9) Good practice}

The TCA has prepared a communication strategy for TGNA, to take a step forward in the relationship between TGNA and TCA. In this document TCA clarifies the activities necessary to strengthen the relationship between the institutions.

With regard to the reports on State Economic Enterprises, the relevant Committee pays specific attention to follow up the audit findings and recommendations regularly.

\section{0) Perspective}

Since huge numbers of audit reports are submitted to the TGNA, there are some difficulties in assessing these reports. If any sub-working groups firstly discussed the reports in a detail manner and then submitted the reports with comments to the Planning and Budget Committee, this Committee could examine these reports more efficiently and take necessary measures. 


\section{UNITED KINGDOM}

National Audit Office

\section{1) Legal framework}

The National Audit Office (NAO) supports Parliament to hold the Government to account for the way public money is spent and to drive improvements in the way public services are delivered. Its primary role is to scrutinise public spending for Parliament.

The NAO is independent of Government. The head of the NAO is the Comptroller and Auditor General (C\&AG), who is an officer of the House of Commons and a Crown appointee.

The Legal framework for the NAO is set out in a number of laws under which:

- It audits the financial statements of all central Government departments, agencies and other public bodies and report the results to Parliament.

- It produces value for money (performance) reports examining the effectiveness, efficiency and economy of Government spending.

The C\&AG has, by law, complete discretion in the discharge of their functions and, in particular, in determining whether to carry out any value for money examinations. In determining whether to carry out any such examination the C\&AG has to "take into account any proposals made by the Committee of Public Accounts," the Parliamentary Committee that takes most of the NAO's work.

Annually, the C\&AG is also required by law to prepare an estimate of the use of resources by the NAO for Parliamentary approval.

\section{2) SAI reporting practices}

Reports can only be submitted to Parliament when it is sitting. Subject to this overriding requirement:

- The results of the NAO's financial audit work are reported separately to Parliament in the form of an opinion published with the annual financial statements by each body and, where the C\&AG considers it necessary, in an accompanying report. Financial audit statements have to be published by 31 January following the end of the financial year (which runs to $31 \mathrm{March}$ ). In practice, most financial statements are published within four months of the end of the financial year. The NAO do not produce separate compliance reports as compliance is covered as part of its financial audit.

- The NAO report the results of its value for money audits separately to Parliament at its discretion. They are addressed to the House of Commons as a whole, not the Speaker or any other individual or any committee of the House. All its value for money reports (and reports on financial statements) are published. In advance of publication the NAO provide embargoed copies of all its reports (and accompanying press releases) by e-mail to the Chair and members of the Committee of Public Accounts. The NAO also provide embargoed copies to those Members of the House of Commons who have requested copies of all its reports (or those on particular subjects) and to members of other committees of the House with an interest in the subject of the report. 
- The NAO provide a range of written outputs, both formal and informal, to other Parliamentary committees on specific issues where the NAO have expertise. Some of these outputs are submitted directly as a memorandum to the relevant committee. Others, such as the 17 short guides the NAO produced for departmental select committees providing an accessible outline of each department for the relevant select committee, the NAO publish itself without formally submitting them to Parliament.

- The NAO produce and submit to Parliament its annual report and accounts. The NAO also publish an annual strategy document setting out its plans for the next 3 years. Copies of both these documents are sent to the Public Accounts Commission (TPAC, a statutory body of Members of Parliament responsible for examining and approving its budget) and the Committee of Public Accounts.

In a small number of cases the NAO, rather than the body, report the results of its financial audit work to Parliament

\section{Procedures for sending reports to Parliament}

The reports the NAO formally submit to Parliament are registered by the House of Commons (and receive a House of Commons number shown on the face of the report). The procedure requires us to supply the House with two printed copies of the report and an accompanying letter.

As noted above the NAO provide embargoed copies of all its reports (and accompanying press releases) by e-mail to the Chair and members of the Committee of Public Accounts, to those Members of the House of Commons who have requested copies of its reports, and to members of other committees of the House with an interest in the subject of the report.

Most of the NAO's value for money reports are considered by the Committee of Public Accounts. Its procedures for briefing that committee are covered below. On request, the NAO provide briefings on any of its reports to other Parliamentary committees or individual Members of Parliament. 
Number and type of reports

\begin{tabular}{|c|c|c|c|c|c|c|c|}
\hline & $\begin{array}{c}\text { Financial } \\
\text { audit reports }\end{array}$ & $\begin{array}{l}\text { Compliance audit } \\
\text { reports }\end{array}$ & $\begin{array}{l}\text { Performance audit } \\
\text { reports }\end{array}$ & $\begin{array}{l}\text { Other reports } \\
\text { or documents }\end{array}$ & $\begin{array}{l}\text { Annual } \\
\text { activity } \\
\text { reports }\end{array}$ & $\begin{array}{l}\text { Reports at } \\
\text { request of } \\
\text { Parliament }\end{array}$ & Remarks \\
\hline $\begin{array}{l}\text { Number } \\
\text { submitted }\end{array}$ & 368 & not applicable & 60 & 0 & 2 & 0 & $\begin{array}{c}\text { All figures are for } \\
\text { financial year } \\
2015-16\end{array}$ \\
\hline $\begin{array}{c}\text { Number discussed } \\
\text { by Parliament }\end{array}$ & 0 & not applicable & 31 & 0 & 2 & 0 & \\
\hline $\begin{array}{l}\text { Submitted to } \\
\text { Speaker }\end{array}$ & \multicolumn{7}{|c|}{$\begin{array}{l}\text { Reports are addressed to the House of Commons as a whole, not the Speaker or any other individual or any } \\
\text { committee of the House. }\end{array}$} \\
\hline $\begin{array}{c}\text { Submitted to Chair } \\
\text { of dedicated } \\
\text { committee }\end{array}$ & \multicolumn{7}{|c|}{ As above } \\
\hline $\begin{array}{l}\text { Copied to other } \\
\text { relevant } \\
\text { committees }\end{array}$ & Not known & not applicable & Not known & 0 & 2 & 0 & $\begin{array}{l}\text { The NAO do not } \\
\text { maintain detailed } \\
\text { records of this }\end{array}$ \\
\hline $\begin{array}{c}\text { Briefings } \\
\text { organised for } \\
\text { Parliamentary } \\
\text { committee }\end{array}$ & Not known & not applicable & At least 31 & 0 & 0 & 0 & $\begin{array}{l}\text { The NAO do not } \\
\text { maintain detailed } \\
\text { records of this }\end{array}$ \\
\hline $\begin{array}{c}\text { Summaries } \\
\text { submitted to } \\
\text { Parliament }\end{array}$ & \multicolumn{7}{|c|}{ The NAO do not submit summaries of its reports to Parliament } \\
\hline
\end{tabular}

\section{3) Parliamentary procedures for SAI reports}

There are no fixed procedures for, or a committee dedicated to, handling NAO reports laid down in Parliament's rules of procedure (Standing Orders). However, in practice, the Committee of Public Accounts (or PAC), appointed by the House of Commons to examine "the accounts ... laid before Parliament ..." fulfils this role.

The PAC, which consists of 15 members is, by convention, chaired by a member of the opposition who, under Standing Orders, is elected by the House of Commons. Under Standing Orders, the committee has the power to send for persons, papers and records and to appoint specialist advisers either to supply information which is not readily available or to elucidate matters of complexity within the committee's order of reference.

The PAC usually appoints one of its members to act as a rapporteur when it takes oral evidence in public from the relevant department (and other expert witnesses) on each of the value for money reports that it chooses to examine. The rapporteur usually takes the lead role in questioning the witnesses, but the Chair and other members will also ask questions. Following the evidence session the committee normally publishes its own report with recommendations on the matter under consideration. The committee 
typically publishes around 50 reports a year. By convention, the Government has to respond to these recommendations within two months of publication.

As the NAO's reports are submitted to the House as a whole (not to a specific committee) and are published, any committee may choose to consider them. In practice, material from its reports is often cited by committees in their inquiries and on the floor of the House, but it is rare for other committees to hold specific evidence sessions on one of the reports.

There are no specific debates on the NAO's work or that of the PAC.

There is a fixed procedure for discharge. The NAO report on the circumstances that have led to any breaches by departments of their budgets, which will lead to a qualified audit opinion on the financial statements. These are often known as Excess Votes because the Government department has exceeded the resources, or particular category of resource, voted to it by Parliament. Under Standing Orders, the PAC is required to consider the reasons behind individual bodies exceeding their allocated resources, and to report to the House on whether it sees any objection to providing the amounts needed to make good the reported excesses. The details in the Committee's report form the basis of the statement of excesses produced by HM Treasury which is put to Parliament to be regularised through a bill. The question on the motion to approve the required amounts is put to the House without debate, if the Committee has reported that the necessary sums should be provided.

\section{Staffing}

PAC has six staff comprising two clerks, three committee assistants, and one media officer. They provide procedural advice and administrative support to the Committee including managing the Committee's correspondence, arranging evidence sessions, publishing the Committee's reports, and handling media inquiries.

The C\&AG is a permanent witness at PAC evidence sessions and, along with NAO staff, provides briefings on each Committee inquiry and assists in the preparation of the Committee's own reports.

\section{SAI involvement in consideration of reports by Parliament}

In advance of each PAC evidence session the NAO provide a written briefing which includes suggested questions. As noted above, the C\&AG and NAO staff attend each evidence session to brief the committee and clarify any issues under discussion during the session. The NAO prepare the first draft of the committee's report for it to consider. It is then for the Chair and subsequently the full committee to consider the draft, amending it as they see fit before agreeing it for publication.

\section{4) SAI reports}

\section{Consideration of reports by Parliament}

The NAO produce a varied range of outputs. While internal control systems is not a subject that is highlighted in its reports, it is covered as part of its financial audit work which also includes wider assurance work such as checking grant claims, reviewing IT systems and certifying savings claimed by departments.

The NAO's value for money programme includes studies of generic/systemic problems and reports that draw on comparisons across the public sector. The NAO focuses on producing work on areas of 
Parliamentary priority, and undertakes investigations that respond to indications of fraud, malpractice or systemic weakness. A value for money report on the implementation of a particular programme or policy may focus on the internal control systems, depending on relevance to particular subjects and circumstance.

Most of The NAO's reports contain clear conclusions and audit opinions. However, its investigations are more narrowly focused than its other value-for-money studies, providing a responsive and fast-paced means to address concerns and issues that the NAO is made aware of. Investigations deliver focused messages on public service delivery and do not necessarily contain conclusions and audit opinions.

\section{5) Follow-up on SAI reports}

The Government has to respond to PAC report recommendations within two months of publication. It typically publishes a Treasury Minute every month or two, responding to a batch of PAC reports. The NAO monitor these responses and provides advice to the Committee on whether follow-up action is required. The Committee holds a number of recall evidence sessions each year to call to account bodies where responses to the Committee's recommendations, or progress in implementing them, appear unsatisfactory.

Audited bodies are not required to publish responses to the NAO's own reports. However, the NAO monitor and discuss with departments the implementation of all its recommendations, both informally and through formal attendance at departments' own Audit Committees. This is one factor the NAO take into account when considering its future Work programme of studies.

\section{6) Audits on Parliament's request}

There is no legal provision enabling Parliament to request audits. The C\&AG has, by law, complete discretion in the discharge of his functions.

Members of Parliament and committees do ask us to provide advice or undertake value for money examinations on specific subjects.

The NAO always seek to provide a constructive response to matters raised and sometimes this leads to full value for money investigations and reports.

\section{7) Work programme}

The C\&AG has, by law, to "take into account any proposals made by the Committee of Public Accounts," when determining whether to carry out any value for money examinations. Accordingly, at regular intervals the NAO discuss its forward programme with the Committee. However, suggestions for inquiries can be made by the Committee at any time. Any changes or new proposals are given very serious consideration and are usually accommodated.

\section{8) Level and frequency of contacts}

As a permanent witness at PAC evidence sessions, the C\&AG attends the Committee twice a week when Parliament is sitting. This is supplemented by informal meetings, particularly with the Chair, on a regular basis throughout the year. The C\&AG also meets Chairs of other committees and other Members of Parliament to discuss matters of common interest.

At working level there are daily contacts with the Committee and its staff. 
The NAO have a dedicated Parliamentary Relations Team of about 7.5 full-time equivalents. The Director of the team is in daily contact with the PAC Chair, as is one member of the team who provides direct support to the Chair in advance of evidence sessions, and provides advice on forthcoming studies.

\section{9) Good practice}

See responses to 10 and 11 below.

\section{0) Perspective}

The NAO aim to be an authoritative source of information and advice within Parliament to help hold Government to account more effectively. The NAO is widening its reach in Parliament, improving its communications and putting more emphasis on building relationships with Members of Parliament, Members' staff and key Parliamentary staff.

The Committee of Public Accounts is its primary client and the NAO is working closely with the Committee to develop its programme of work. The NAO is also broadening its work with Parliament, increasing its support to both Houses of Parliament, and increasing its value to select committees and MPs generally.

The NAO plan to work more closely with Parliament to help tailor its products and support to MPs' needs. To do this, the NAO is increasing its understanding of the House of Commons through secondments and recruitment. Its new directors of Parliamentary relations and external relations have extensive experience of working in Parliament. The NAO is running reciprocal secondments with the main committees and other House of Commons staff, and building closer relationships with the House of Commons Library.

11) Are there any other relevant features of the current relations between the SAI and Parliament that you would like to highlight, and how have they evolved over the past five years?

Over recent years, with the allocation of additional resources for supporting Parliament more widely, the NAO have developed stronger links with other select committees and supported them in a variety of ways, including written and oral briefings, secondments of staff and short-term attachments to committees, and by appearing before them to give formal oral evidence. This work has been carried out with the full support of the PAC and TPAC and has been accepted by departments. 


\section{THE SIGMA PROGRAMME}

SIGMA (Support for Improvement in Governance and Management) is a joint initiative of the OECD and the EU, principally financed by the EU. SIGMA has been working with countries on strengthening public governance systems and public administration capacities for 25 years.

In partnership with the European Commission (EC) Directorate-General for Neighbourhood and Enlargement Negotiations (DG NEAR), we currently work with:

- Albania, Bosnia and Herzegovina, the former Yugoslav Republic of Macedonia, Kosovo, Montenegro, Serbia, and Turkey as EU candidate countries and potential candidates

- Algeria, Armenia, Azerbaijan, Egypt, Georgia, Jordan, Lebanon, Moldova, Morocco, Tunisia and Ukraine as EU Neighbourhood countries

SIGMA provides assistance in six key areas:

1. Strategic framework of public administration reform

a) Policy development and co-ordination

b) Public service and human resource management

c) Accountability

d) Service delivery

e) Public financial management, public procurement and external audit

SIGMA reviews and gives feedback on:

- Governance systems and institutions

- Legal frameworks

- Reform strategies and action plans

- Progress in reform implementation

SIGMA provides:

- Advice on the design and prioritisation of reforms

- Methodologies and tools to support implementation

- Recommendations for improving laws and administrative arrangements

- Opportunities to share Good practice from a wide range of countries, including regional events

- Policy papers and multi-country comparative studies.

For further information on SIGMA, consult our website:

www.sigmaweb.org

\section{(C) OECD 2017}

As SIGMA is part of the Organisation for Economic Co-operation and Development (OECD), the same conditions of use apply to its publications: http://www.oecd.org/termsandconditions. 